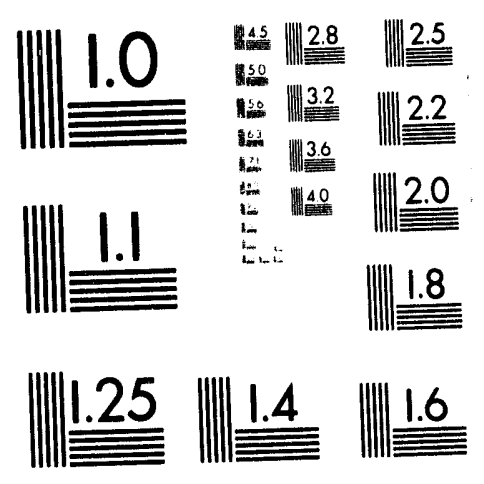



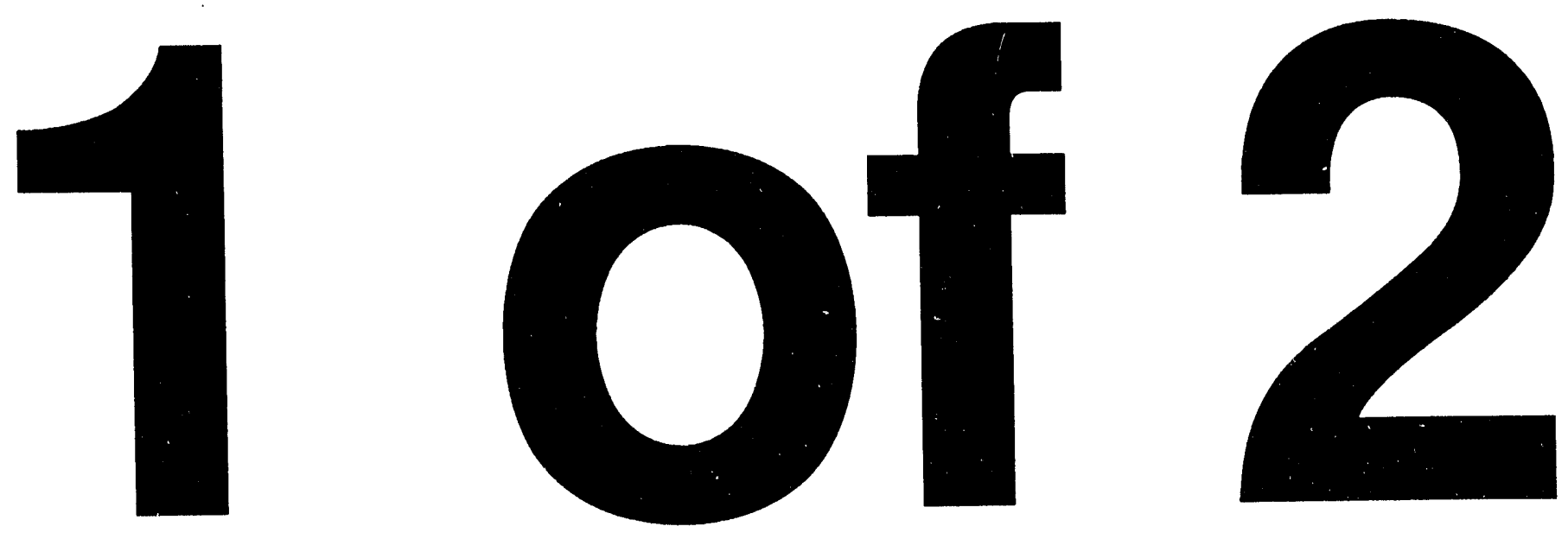
DOE/EIA-0206(92)

Distribution Category UC-950

\title{
Performance Profiles of Major Energy Producers 1992
}

\section{January 1994}

\author{
Energy Information Administration \\ Office of Energy Markets and End Use \\ U.S. Department of Energy \\ Washington, DC 20585
}

This report was prepared by the Energy Information Administration, the independent statistical and analytical agency within the Department of Energy. The information contained herein should not be construed as advocating or reflecting any policy position of the Department of Energy or any other organization. 


\section{Contacts}

This report was prepared in the Office of Energy Markets and End Use of the Energy Information Administration, U.S. Department of Energy, under the general direction of $W$. Calvin Kilgore. The project was directed by Arthur T. Andersen, Director of the Energy Markets and Contingency Information Division (202) 586-1441, and Mary E. Northup, Chief of the Financial Analysis Branch (202) 586-1445. Specific technical information concerning this report, and the associated data survey (Form EIA-28), may be obtained from Jon A. Rasmussen (202) 586-1449. Questions concerning the availability of aggregate time-series data on diskette may be obtained from Gregory Filas (202) 586-1347. 


\section{Preface}

The purpose of this publication is to examine developments in the operations of the major U.S. energy-producing companies on a corporate level, by major line of business, by major function within each line of business, and by geographic area.

Pursuant to Section 205(h) of the Department of Energy Organization Act, which established the Financial Reporting System (FRS), the Energy Information Administration (EIA), through its Form EIA-28, collects financial information and other measures of energyrelated business efforts and results for major energy companies. Since the FRS data are collected on a uniform, segmented basis, the comparability of information across energy lines of business is unique to this reporting system. For example, petroleum activities can be compared to activities in other energy lines of business or nonenergy areas, and domestic activities can be compared to foreign activities.

This report presents data collected on Form EIA-28 for the calendar year 1992. In 1992, 25 companies filed
Form EIA-28. The analysis and data presented in this report represent the operations of the FRS companies in the context of their worldwide operations and in the context of the major energy markets which they serve. Both energy and nonenergy developments of these companies are analyzed. Although the focus is on developments in 1992, important trends prior to that time are also featured.

Economic performance, in financial and physical dimensions, continues to serve as a significant factor in evaluating past decisions and guiding future options in the development and supply of energy resources. The information contained in this report is intended to promote an understanding and provide a critical review of the possible motivations and apparent consequences of investment decisions by some of the largest corporations in the energy industry. The information is intended for use by the U.S. Congress, Government agencies, industry analysts, and the general public. 


\section{Contents}

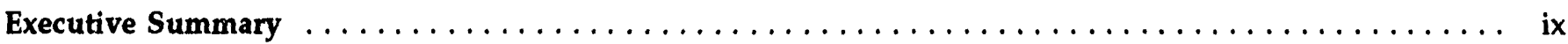

1. Energy Markets in 1992: Weak Financial Results $\ldots \ldots \ldots \ldots \ldots \ldots \ldots \ldots \ldots \ldots \ldots \ldots \ldots \ldots \ldots$

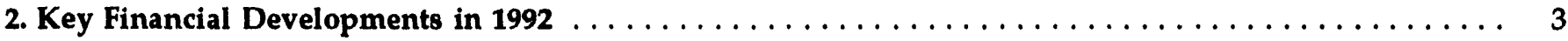

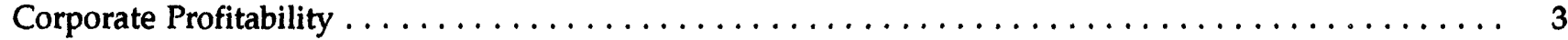

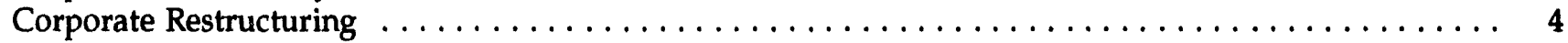

Corporate Liquidity and Uses of Funds $\ldots \ldots \ldots \ldots \ldots \ldots \ldots \ldots \ldots \ldots \ldots \ldots \ldots \ldots \ldots \ldots \ldots \ldots$

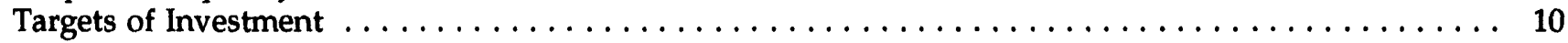

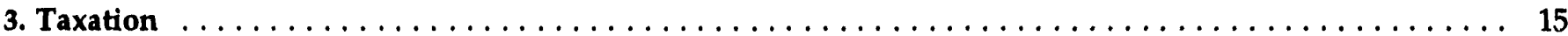

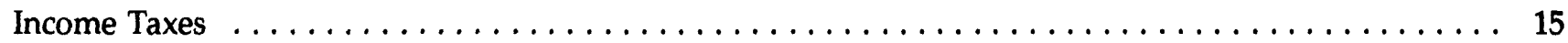

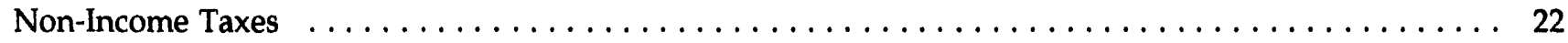

4. Oil and Gas Exploration, Development, and Production in $1992 \ldots \ldots \ldots \ldots \ldots \ldots \ldots \ldots \ldots$

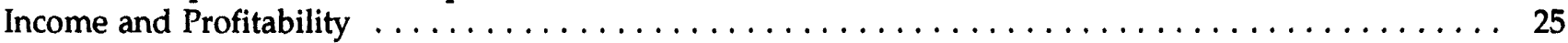

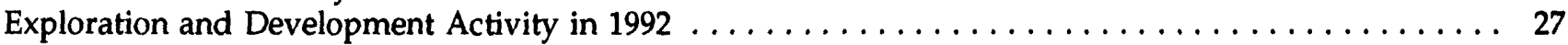

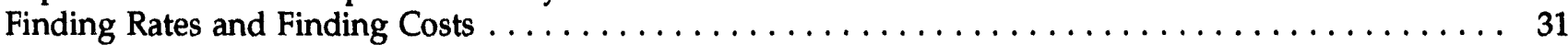

FRS Company Upstream Activity Highlights in $1992 \ldots \ldots \ldots \ldots \ldots \ldots \ldots \ldots \ldots \ldots \ldots \ldots$

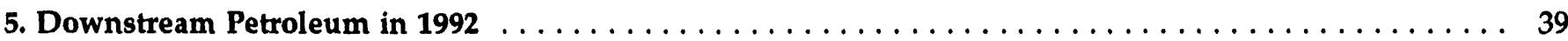

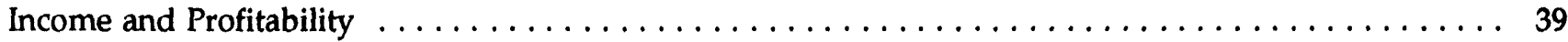

Capital Expenditure for Refining and Marketing $\ldots \ldots \ldots \ldots \ldots \ldots \ldots \ldots \ldots \ldots \ldots \ldots \ldots \ldots \ldots$

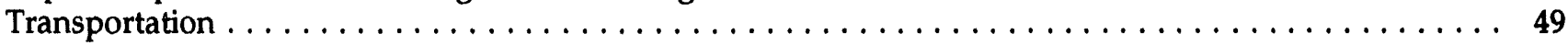

6. Coal, Alternative Energy, and Research and Development $\ldots \ldots \ldots \ldots \ldots \ldots \ldots \ldots \ldots \ldots \ldots$

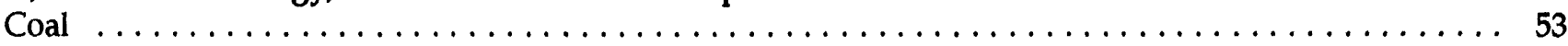

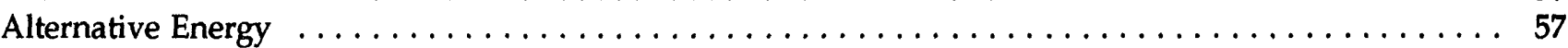

Research and Development $\ldots \ldots \ldots \ldots \ldots \ldots \ldots \ldots \ldots \ldots \ldots \ldots \ldots \ldots \ldots \ldots \ldots$

Appendices

A. Structure of the Financial Reporting System - Form EIA-28 $\ldots \ldots \ldots \ldots \ldots \ldots \ldots \ldots \ldots \ldots$

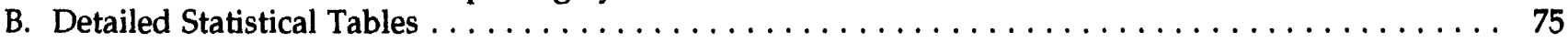

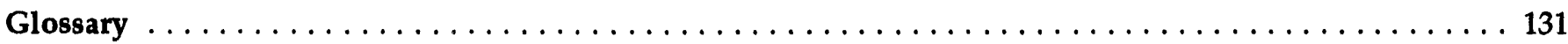




\section{Tables}

1. Comparison of Selected Financial Items for FRS Companies and the S\&P 400, $1992 \ldots \ldots \ldots \ldots$

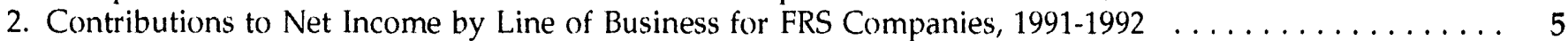

3. Rates of Return by Line of Business for FRS Companies, $1986-1992 \ldots \ldots \ldots \ldots \ldots \ldots \ldots \ldots \ldots \ldots$

4. Operating Income in Chemicals and Other Nonenergy Segments for FRS Companies, 1991-1992 _. . . . 8

5. Line-of-Business Contributions to Pretax Cash Flow for FRS Companies, $1991-1992 \ldots \ldots \ldots \ldots \ldots$

5. Sources and Uses of Cash for FRS Companies, $1991-1992 \ldots \ldots \ldots \ldots \ldots \ldots \ldots \ldots \ldots \ldots \ldots$

7. Additions to Investment in Place by Line of Business for FRS Companies, 1991-1992 _ . . . . . . . . 11

8. Value of Mergers, Acquisitions, and Related Transactions by FRS Companies, $1992 \ldots \ldots \ldots \ldots \ldots \ldots$

9. Income Tax Expense, Pretax Income, and Tax Shares for FRS Companies, 1990-1992 . . . . . . . . . . 16

10. Tax Offsets from Asset Writedowns and Other Special Charges for FRS Companies, 1990-1992 . . . . . . . 18

11. Change in Income Tax Expense from 1991 to 1992, by Source . . . . . . . . . . . . . . . . . . . . 19

12. Income Tax Expense, Pretax Income and Effective Tax Rates: U.S., Foreign, and Consolidated

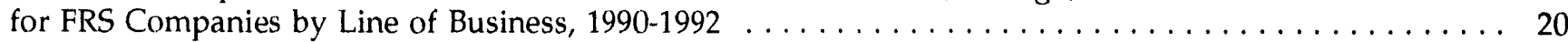

13. Composition of Income Tax Expense for FRS Companies, $1990-1992 \ldots \ldots \ldots \ldots \ldots \ldots \ldots \ldots \ldots \ldots$

14. Deferred, Current, and Total Income Tax Expense for FRS Companies, 1990-1992 . . . . . . . . . . 22

15. U.S., Foreign, and Worldwide Effective Inconıe Tax Rates for FRS Companies, 1990-1992 . . . . . . . . . . 23

16. Additional U.S. Tax Liabilities of FRS Companies, $1990-1992 \ldots \ldots \ldots \ldots \ldots \ldots \ldots \ldots \ldots \ldots \ldots \ldots$

17. Income Components and Financial Ratios in Oil and Gas Production for FRS Companies, 1991-1992 . . . 26

18. Average Prices, Sales, and Production in Oil and Gas for FRS Companies, 1991-1992 . . . . . . . . . . 27

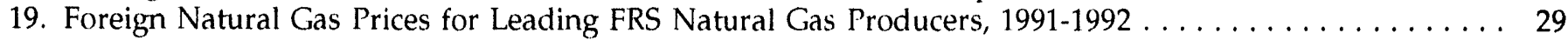

20. Exploration and Development Spending for FRS Companies by Region, 1991-1992 . . . . . . . . . . . . 29

21. Property Acquisition, Exploration, and Development Expenditures for FRS Companies, 1991-1992 . . . . 30

22. Well Completions by Region for FRS Companies, $1990-1992 \ldots \ldots \ldots \ldots \ldots \ldots \ldots \ldots \ldots \ldots \ldots \ldots . \ldots 31$

23. Oil and Gas Reserves and Production for FRS Companies, $1991-1992 \ldots \ldots \ldots \ldots \ldots \ldots \ldots \ldots \ldots \ldots$

24. Oil and Gas Reserve Additions by Region for FRS Companies, $1990-1992 \ldots \ldots \ldots \ldots \ldots \ldots \ldots \ldots \ldots$

25. Sales, Expenses, and Income in U.S. Refining/Marketing for FRS Companies, 1991-1992 . . . . . . . . . 40

26. Components of Refined Product Margin for FRS Companies, $1989-1992 \ldots \ldots \ldots \ldots \ldots \ldots \ldots \ldots$

27. Refining and Marketing Financial Items and Operating Data for FRS Companies, 1991-1992 _ . . . . . . 42

28. FRS Foreign Refining Capacity, Selected Years, $1974-1992 \ldots \ldots \ldots \ldots \ldots \ldots \ldots \ldots \ldots \ldots \ldots \ldots \ldots$

29. Worldwide Consumption of Refined Products, $1990 \ldots \ldots \ldots \ldots \ldots \ldots \ldots \ldots \ldots \ldots \ldots \ldots \ldots . \ldots 4$

30. Worldwide Downstream Refining Capacity, January $1,1993 \ldots \ldots \ldots \ldots \ldots \ldots \ldots \ldots \ldots \ldots \ldots \ldots 47$

31. Financial Items for Transportation for FRS Companies, $1991-1992 \ldots \ldots \ldots \ldots \ldots \ldots \ldots \ldots \ldots \ldots \ldots$

32. Coal Production Indicators for the FRS Companies, $1991-1992 \ldots \ldots \ldots \ldots \ldots \ldots \ldots \ldots \ldots \ldots \ldots \ldots \ldots$

33. Financial Items in Coal for a Consistent Group of FRS Companies, $1991-1992 \ldots \ldots \ldots \ldots \ldots \ldots \ldots$

34. Revenues, Income, and Investment in Other Energy for FRS Companies, 1991-1992 _ . . . . . . . . . 57

35. Worldwide Research and Development Expenditures for FRS Companies, 1991-1992 . . . . . . . . . . 59

B1. Selected U.S. Operating Statistics for FRS Companies and U.S. Industry, 1991 and $1992 \ldots \ldots \ldots \ldots$

B2. Selected U.S. Operating Statistics for FRS Companies and U.S. Industry, $1986-1992 \ldots \ldots \ldots \ldots \ldots \ldots$

B3. A Comparison of Selected Financial Items for FRS Companies and the S\&P 400, 1992

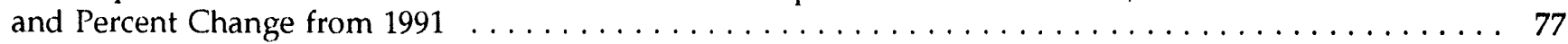

B4. Consolidating Statement of Income for FRS Companies, $1992 \ldots \ldots \ldots \ldots \ldots \ldots \ldots \ldots \ldots \ldots \ldots \ldots 78$

B5. Consolidating Statement of Income for FRS Companies, U.S. and Foreign Petroleum Segments,

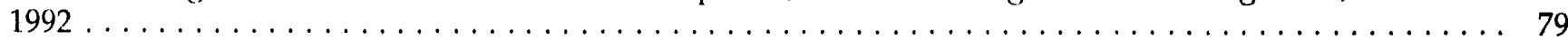

B6. Profit Rates for Lines of Business and Petroleum Segments for FRS Companies, 1986-1992 _ . . . . . . 80

B7. Profit Rates for Petroleum Segments for FRS Companies Ranked by Total Energy Assets, 1990-1992

B8. A Comparison of Balance Sheet Items for FRS Companies and the S\&P 400, 1992 and

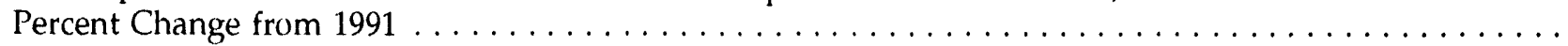

B9. Consolidated Balance Sheet for FRS Companies, $1986-1992 \ldots \ldots \ldots \ldots \ldots \ldots \ldots \ldots \ldots \ldots \ldots \ldots \ldots$

B10. Distribution of Net Investment in Place for FRS Companies, United States and Foreign, $1992 \ldots \ldots$. . . . . 84

B11. Net Property, Plant and Equipment (PP\&E), Additions to PP\&E, Investments and Advances, and Depreciation, Depletion and Amortization (DD\&A), by Lines of Business for FRS Companies, $1992 \ldots \ldots$ 
B12. Income and Investment Patterns in Worldwide Petroleum for FRS Companies Ranked by Total Energy Assets, 1992 and Percent Change from 1991

B13. Income and Investment Patterns by Petroleum Segments for FRS Companies Ranked by Total Energy Assets, 1992 and Percent Change from 1991

B14. Size Distribution of Income and Investment Within Worldwide Petroleum for FRS Companies Ranked by Total Energy Assets, $1990-1992 \ldots \ldots \ldots \ldots \ldots \ldots \ldots \ldots \ldots \ldots \ldots \ldots \ldots$

B15. Consolidated Statement of Cash Flows for FRS Companies, $1986-1992 \ldots \ldots \ldots \ldots \ldots \ldots \ldots \ldots$

B16. A Comparison of Key Financial Indicators, Selected Performance Measures, and Patterns of Finance for FRS Companies and for the $S \& P 400,1990-1992 \ldots \ldots \ldots \ldots \ldots \ldots \ldots \ldots \ldots \ldots$

B17. Worldwide Income Taxes for FRS Companies, 1991 and $1992 \ldots \ldots \ldots \ldots \ldots \ldots \ldots \ldots \ldots \ldots \ldots$

B18. U.S. Federal Income Taxes for FRS Companies, 1991 and $1992 \ldots \ldots \ldots \ldots \ldots \ldots \ldots \ldots \ldots \ldots \ldots \ldots$

B19. Analysis of Income Taxes for FRS Companies, $1986-1992 \ldots \ldots \ldots \ldots \ldots \ldots \ldots \ldots \ldots \ldots \ldots \ldots . \ldots 3$

B20. U.S. Taxes Other Than Income Taxes for FRS Companies, 1992 and Percent Change from $1991 \ldots \ldots$.

B21. Petroleum Exploration and Development Expenditures for FRS Companies, United States and Foreign, 1992 and Percent Change from 1991

B22. U.S. and Foreign Exploration and Development Expenditures and Production (Lifting) Costs

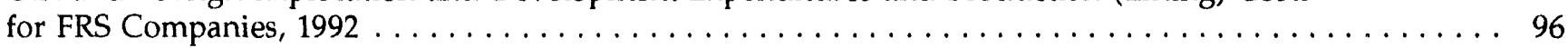

B23. Total Exploratory and Development Wells Drilled in the United States for FRS Companies and

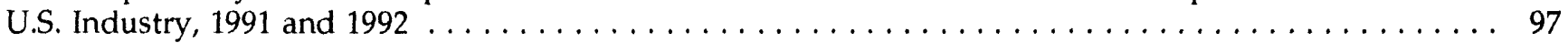

B24. Completed Well Costs, Oil, Gas, and Dry, for FRS Companies and U.S. Industry, 1991 and 1992 . . . . . 98

B25. Completed Well Costs, Oil, Gas, and Dry, Onshore and Offshore, for FRS Companies,

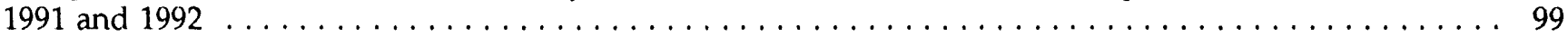

B26. U.S. Net Wells Completed, and Net In-Progress Wells for FRS Companies, 1986-1992 . . . . . . . . . . 100

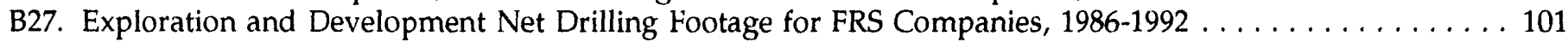

B28. U.S. Net Producing Wells, and U.S. Acreage for FRS Companies, $1986-1992 \ldots \ldots \ldots \ldots \ldots \ldots \ldots \ldots$

B29. U.S. Net Petroleum Acreage for FRS Companies, Ranked by Total Energy Assets,

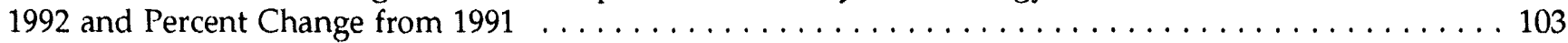

B30. U.S. Net Ownership Interest Petroleum Reserves and Production for FRS Companies and

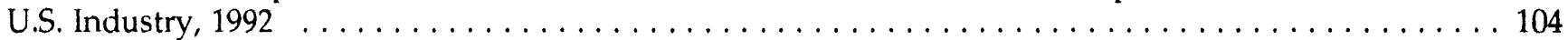

B31. Proved Petroleum Reserves for FRS Companies, United States and Foreign, $1992 \ldots \ldots \ldots \ldots \ldots \ldots$

B32. U.S. Reserve Additions, Exploration and Development Expenditures, and Expenditures per Barrel of Reserve Additions for FRS Companies Ranked by Total Energy Assets and for U.S. Industry,

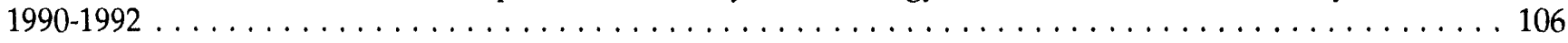

B33. Foreign Petroleum Exploration, Development, Reserves, and Production Statistics by Geographic Area for FRS Companies and Foreign Industry, 1992 and Percent Change from 1991 . . . . . . . . . 107

B34. Foreign Exploration and Development Expenditures by Region for FRS Companies, 1986-1992 . . . . . . . 108

B35. Distribution of Foreign Exploration and Development Expenditures for FRS Companies Ranked by Total Energy Assets, 1992 and Percent Change from $1991 \ldots \ldots \ldots \ldots$. . . . . . . . . . . . . . . . . 109

B36. Number of Net Wells Completed, Net In-Progress Wells, and Net Producing Wells in Foreign

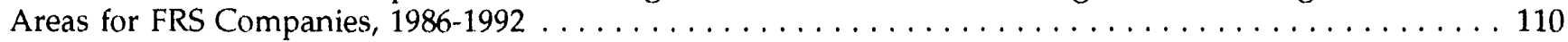

B37. Foreign Proved Oil and Gas Reserves for FRS Companies, $1992 \ldots \ldots \ldots \ldots \ldots \ldots \ldots \ldots \ldots \ldots \ldots \ldots 112$

B38. Foreign Production (Lifting) Costs for FRS Companies, $1986-1992 \ldots \ldots \ldots \ldots \ldots \ldots \ldots \ldots \ldots \ldots$

B39. U.S. Refining/Marketing Dispositions of Refined Products by Channe! of Distribution for

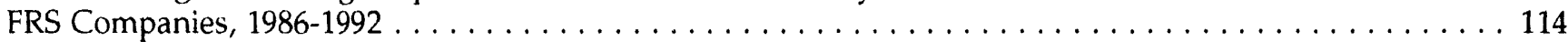

B40. Sales of U.S. Refined Products, by Volume and Price, for FRS Companies Ranked by

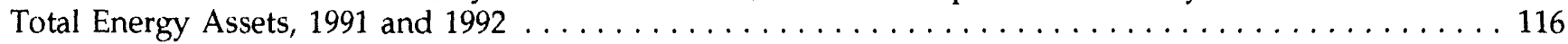

B41. U.S. Petroleum Refining/Marketing, General Operating Expenses for FRS Companies, 1986-1992 _ . . . . 117

B42. U.S. Petroleum Segments Purchases and Sales of Raw Materials and Refined Products for

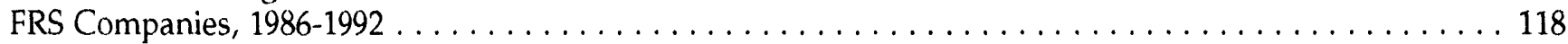

B43. U.S. and Foreign Refining/Marketing Segment, Sources and Dispositions of Crude Oil and

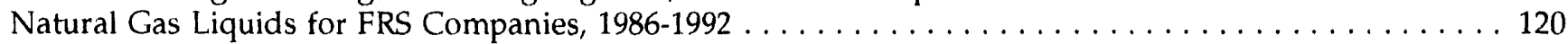

B44. U.S. and Foreign Oil Raw Materials Balance for FRS Companies Ranked by Total Energy Assets, 1990-1992

B45. U.S. Refinery Output and Refinery Capacity Statistics for FRS Companies, Ranked by Total Energy Assets, and for U.S. Industry, 1991 and 1992 
B46. Foreign Refinery Output and Refinery Capacity Statistics for FRS Companies, Ranked by

Total Energy Assets, and for Foreign Industry, 1991 and $1992 \ldots \ldots \ldots \ldots \ldots \ldots \ldots \ldots \ldots \ldots \ldots$

B47. U.S. and Foreign Petroleum Refining Statistics for FRS Companies, 1986-1992 . . . . . . . . . . . . . . . 124

B48. U.S. Refining/Marketing Revenues and Costs for FRS Companies, 1990-1992 . . . . . . . . . . . . . 125

B49. Sources of U.S. Bituminous Coal and Lignite Production, by Region and Mining Method, for FRS Companies and U.S. Industry, 1992 and Percent Change From $1991 \ldots \ldots \ldots \ldots \ldots \ldots \ldots$

B50. U.S. Coal Reserves Balance for FRS Companies, $1986-1992 \ldots \ldots \ldots \ldots \ldots \ldots \ldots \ldots \ldots \ldots \ldots \ldots \ldots$

B51. U.S. Coal Reserves (End of Year) and Production Statistics for FRS Companies, 1986-1992 . . . . . . . 128

B52. Research and Development Expenditures for FRS Companies, 1986-1992 . . . . . . . . . . . . . . 129

\section{Illustrations}

1. Operating Revenues by Line of Business for FRS Companies, $1981-1992 \ldots \ldots \ldots \ldots \ldots \ldots \ldots$

2. FRS Companies' Share of U.S. Energy Production and Refinery Capacity, 1981-1992 . . . . . . . . . . . . . 2

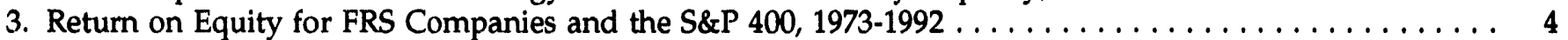

4. Rates of Return by Line of Business for FRS Companies, $1977-1992 \ldots \ldots \ldots \ldots \ldots \ldots \ldots \ldots \ldots \ldots \ldots$

5. Number of Employees of FRS Companies, $1981-1992 \ldots \ldots \ldots \ldots \ldots \ldots \ldots \ldots \ldots \ldots \ldots \ldots \ldots$

6. Revenues and Operating Expenses for the Chemical Segment for FRS Companies, $1981-1992 \ldots \ldots \ldots$. . . 7

7. Financial Ratios for FRS Companies, $1981-1992 \ldots \ldots \ldots \ldots \ldots \ldots \ldots \ldots \ldots \ldots \ldots \ldots \ldots \ldots$

8. Additions to Investment in Place and Value of Acquisitions and Mergers for FRS Companies,

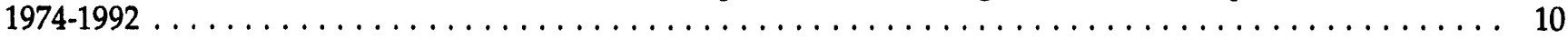

9. Worldwide Tax Liabilities for FRS Companies, $1981-1992 \ldots \ldots \ldots \ldots \ldots \ldots \ldots \ldots \ldots \ldots \ldots \ldots \ldots$

10. Worldwide Tax Liabilities for FRS Companies, 1991 and $1992 \ldots \ldots \ldots \ldots \ldots \ldots \ldots \ldots \ldots \ldots \ldots$

11. Worldwide Effective Income Tax Rates for FRS Companies and S\&P 400, 1981-1992 . . . . . . . . . . 20

12. Direct Oil and Gas Production Costs for FRS Companies, $1981-1992 \ldots \ldots \ldots \ldots \ldots \ldots \ldots \ldots \ldots$

13. Rates of Return in U.S. and Foreign Production for FRS Companies, 1977-1992 . . . . . . . . . . . . . 27

14. FRS Companies' U.S. and Foreign Exploration and Development Expenditures in 1992 Dollars, $1977-1992$. . . . . . . . . . . . . . . . . . . . . . . . . . . . . . . . . . . . . . . . . . . . . . 29

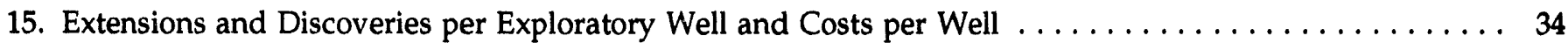

16. Finding Costs in the United States and Outside North America $\ldots \ldots \ldots \ldots \ldots \ldots \ldots \ldots \ldots \ldots \ldots . \ldots 34$

17. Reserves Added per Well and the Finding Costs of the FRS Companies . . . . . . . . . . . . . . . 35

18. U.S. vs. Foreign Finding Costs for Independent Producers, $1988-1992 \ldots \ldots \ldots \ldots \ldots \ldots \ldots \ldots \ldots \ldots$

19. Refining and Marketing Return on Investment for the FRS Companies, 1981-1992 . . . . . . . . . . . 39

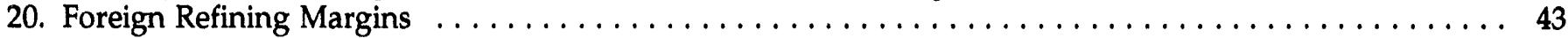

21. Rates of Return for Petroleum Transportation for FRS Companies, $1981-1991 \ldots \ldots \ldots \ldots \ldots \ldots$ 


\section{Executive Summary}

Performance Profiles of Major Energy Producers 1992 is the sixteenth annual report of the Energy Information Administration's (EIA) Financial Reporting System (FRS). The report examines financial and operating developments, with particular reference to the 25 major energy companies (the FRS companies) required to report annually on Form EIA-28. Financial information is reported by major lines of business, including oil and gas production, petroleum refining and marketing, and other energy operations. Domestic and international operations are examined separately in this report. The data are presented in the context of key energy market developments with a view toward identifying changing strategies of corporate development and measuring the apparent success of current ongoing operations.

\section{Corporate Profitability}

Profits fell for the FRS companies in 1992. Reported net income totaled only $\$ 1.8$ billion, down 88 percent from 1991, yielding a record low return on stockholders' equity of only 1 percent. The fall was mainly a consequence of an unusual change in financial disclosure requirements, which led to a one-time downward adjustment of corporate profits. Net income from ongoing operations did decline, but by only 4 percent, from $\$ 15.7$ billion in 1991 to $\$ 15.1$ billion in 1992, excluding the effects of accounting changes and other unusual items. However, 1992 was also the second consecutive year of decline in operating profits. Average rates of return for most continuing lines of business declined to levels that were lower than at any time since 1986.

\section{Accounting for Retiree Health Benefits}

In December of 1990, the Financial Accounting Standards Board (FASB) issued statement No. 106, "Employers' Accounting for Postretirement Benefits Other Than Pensions" (SFAS 106). The statement addresses the way in which companies account for postretirement benefits other than pensions for existing and retired employees (the most important of which is health care). Henceforth, the present value of such benefits must be calculated annually and recorded as a liability. The accumulation of past obligations must also be calculated and recognized as a liability. Heretofore, most companies recognized postretirement cost commitments on an "as paid" rather than on an "as obligated" basis.

FRS companies reported that total existing postretirement obligations had an estimated value of nearly $\$ 11$ billion in 1992 . In effect, past costs had been understated by this amount, necessitating a one-time catch-up offset to current profits. FRS companies were not alone in addressing this requirement. Fortune reported that among the 500 largest U.S. industrial corporations, a one-time recognition of previously nonrecorded retiree costs equaled $\$ 70$ billion, equivalent to virtually all recorded profits for this group in 1992.

\section{The Decline in Operating Profits}

Operating profits for FRS companies declined in 1992 for the second consecutive year. Net income, excluding unusual items, also fell during those years. In 1992 it fell by 4 percent. This followed a decline of 33 percent for 1991. The overall rate of return on the FRS companies' worldwide petroleum operations, which accounted for approximately 80 percent of revenue and investment, equaled 5.6 percent. Only once in the past two decades did the FRS companies earn a lower rate of return from their overall petroleum activities. That year was 1986, when oil prices collapsed.

Rates of return for nonpetroleum lines of business have also trended downward in recent years. The largest area of decline involves nonenergy operations; the most important of which is chemical manufacture. In the late 1980's these activities yielded rates of return between 12 and 20 percent for the FRS companies, which were then 2 to 3 times higher than for petroleum. Rates of return on nonenergy assets in 1992 (at 2.1 percent) were less than half those recorded for worldwide petroleum operations. 
The weakest performance within the petroleum sector in 1992 involved U.S. refining and marketing operations. Returns turned negative for the first time since FRS data collection began in 1977. Average product prices, and refined product margins declined. While raw material costs declined, refined product prices declined even more. Further, capital, processing, and distribution costs rose, in part as a consequence of environmental regulations, including requirements for the marketing and distribution of oxygenated gasoline.

Within the United States, improved profitability of upstream oil and gas production, which includes all operations up to and including production, nearly offset the decline in refining profitability. Improved upstream profitability was achieved despite continued reductions in crude oil production and prices. Natural gas sales were key to the improvement. The average wellhead price for natural gas for the FRS companies rose 8 percent in 1992, while their natural gas sales quantities increased 11 percent. An additional factor improving upstream profits involved further rationalization of oil producing assets. For the third consecutive year, FRS companies were net sellers of domestic oil and gas reserves. In 1992, more than 600 million barrels of reserves were sold off. Between 1991 and 1992, FRS companies sold upstream assets and reduced their number of producing wells by over 8,000 , or 5 percent. Production costs per unit of output associated with remaining operations averaged 14 percent less than in 1991.

Operating profits attributed to foreign petroleum operations fell by nearly $\$ 4$ billion or by about 25 percent in 1992. The biggest decline was in foreign refining and marketing. However, upstream profitability also declined as lower oil prices more than offset increases in foreign production. In addition, tanker profits, which increased in the context of the Persian Gulf war and its aftermath, plunged in 1992. Despite these decreases, the average rate of return for FRS company foreign petroleum operations (7.9 percent) was nearly twice the level realized from domestic operations (4.4 percent) in 1992.

\section{Investment Patterns}

Capital expenditures by FRS companies (excluding mergers and acquisitions) have exceeded $\$ 40$ billion in each year since 1990. During this period about onequarter of all investment has been allocated to nonpetroleum lines of business, with the balance going to petroleum operations. Thus, despite recent declines in rates of return, aggregate levels of investment activity by FRS companies have been sustained at high levels.

Nonetheless, significant changes in investment emphasis are evident. The most notable change was in oil and gas exploration and development. In 1992, for the first time since the initial year (1974) of FRS data, the FRS companies' exploration and development expenditures outside the United States exceeded spending in domestic areas.

\section{U.S. Oil Exploration at Record Low Levels}

Between 1990 and 1992, FRS exploration and development spending in the United States fell by over 30 percent, with most of the cuts implemented between 1991 and 1992. Adjusted for inflation, FRS exploration and development spending in the United States was lower in 1992 than in any year since 1977. Drilling activity reflected the spending cuts. The number of exploratory wells drilled by FRS companies fell by 32 percent in 1992 relative to 1991, while the number drilled by non-FRS companies fell 23 percent. For FRS companies and the industry as a whole, exploratory drilling fell more than development drilling in percentage terms, reflecting limited exploration opportunities in frontier areas in the United States. While the number of completed FRS development wells decreased by 22 percent in 1992, the number of non-FRS development well completions fell by 20 percent. In total, exploration and development activities in the United States fell to record low levels in 1992 when measured by the number of well completions, footage drilled, and rotary rigs in operation.

\section{Increasing Emphasis on Foreign Upstream Spending}

Foreign exploration and development spending by FRS companies totaled $\$ 13$ billion in 1992, down about 6 percent compared to 1991. Thus, while overall exploration and development spending by FRS companies was reduced by $\$ 4.7$ billion between 1991 and 1992 , only $\$ 0.8$ billion of the cut was applied to foreign operations. To better dramatize the magnitude of change in FRS exploration strategy emphasizing foreign development, it should be noted that 1992 levels of exploration and development spending abroad are now 72 percent larger than in 1986, while U.S. exploration spending has declined more than 41 percent in that period. 
As a result of the geographical shift in exploration and development expenditures, the number of producing oil and gas wells owned by FRS companies is rising abroad while the number is declining in the United States. The contrast is particularly striking between the United States and locales outside North America. Between 1986 and 1992, the number of FRS companies' U.S. producing wells declined 29 percent, while producing wells outside North America rose 6 percent. Domestic wells still outnumber wells outside North America by about 20 to one. However, the ratio of total oil output per well highlights the greater importance of the average foreign well. In 1992, 118,000 FRS domestic oil wells supplied 1.8 billion barrels of oil. In the same year, 7,400 FRS oil wells outside North America supplied 1.1 billion barrels. Average productivity per oil well outside North America was 10 times greater than in the United States.

\section{Domestic Refinery Investment}

Despite declining profitability, FRS companies' investments in domestic refinery operations have increased. Investment expenditures in 1992 equaled $\$ 5.2$ billion compared with $\$ 4.8$ billion in 1991. This increased investment occurred while basic refinery capacity fell by more than 2 percent. The major objective of this investment is to improve refinery processing capability to remove sulfur from crude oil inputs and to reform heavy crude oil components into light products, especially unleaded gasoline. Much of the investment was also driven by a need to upgrade manufacturing capability to provide environmentallysatisfactory transportation fuel. In 1992, new requirements for oxygenated gasoline went into effect. These requirements necessitated investments in 1991 and earlier. Much of the investment of 1992 is preparatory for meeting new low-sulfur fuel requirements which became effective in 1993.

\section{Exit from Coal Production Accelerates}

Through a series of asset sales and partial divestitures, FRS company involvement in the U.S. coal industry was substantially reduced in 1992. Nearly one-half of all FRS U.S. coal reserve and produciion operations were sold. As recently as 1988, FRS companies accounted for 30 percent of domestic coal output. By 1993 the share will be less than 20 percent. Coal has failed to provide a strong profit base for FRS companies. Rates of return have consistently trailed those realized in the petroleum sector. Within all FRS company energy operations, only nuclear and alternate energy have yielded lower rates of return.

Withdrawal from nuclear and alternative energy lines of business began in the early 1980's. In 1992, net investment in place for these lines of business (at $\$ 2.8$ billion) equaled only one half the book value of investment in place in 1982. The book value of investment in place for coal operations changed little in the 1980's even after the oil price collapse of 1986. However, between 1990 and 1992 the book value of continuing investment in coal operations fell by nearly one-half, principally because of the sale of coal assets.

Commercial alternative energy operations for FRS companies primarily involve production of oil from Canadian tar sands, steam from geothermal reservoirs, and electric power generation from gas-fired cogeneration facilities. Two companies maintain solar power subsidiaries, with small commercial sales. At this time, except for cogeneration, no alternative energy line of business is the object of significant expansion for FRS companies. 


\section{Energy Markets in 1992: Weak Financial Results}

The financial performance of the 25 major energy companies that report to the Energy Information Administration's Financial Reporting System (FRS) deteriorated in 1992. ${ }^{1}$ The FRS companies' overall corporate financial results are based on a combination of their petroleum operations, their coal and other energy businesses, and their chemicals and various diversified operations. (See the box below that describes the FRS companies and their operations.) Petroleum operations generate 82 percent of all revenues. Chemical lines of business are next in importance. The deterioration in overall performance in 1992 resulted not only from developments in the petroleum sector but also from coal market developments.

The year began poorly for all segments of the petroleum industry, with falling oil and natural gas prices, weak economic growth, and reduced refined product margins. After the first quarter, U.S. natural gas prices improved substantially due to a combination of cooler weather and elimination of an overhang of excessive levels of gas in storage. On average, the wellhead price for natural gas increased 10 percent relative to $1991 .^{2}$ Oil prices fluctuated throughout the year and ended with an average decline of 3 percent.

Domestic oil and gas production in 1992, on a combined basis, was down 1 percent from the previous year. The increase in natural gas prices and production domestically enabled a small improvement in upstream profitability in the United States. In contrast, downstream petroleum operations, which includes all stages beyond production, fared poorly in financial terms in the United States. For the first time, the overall profit rate for FRS refining was negative. In the United States, slow growth resulted in weak product demand, which caused product prices and refining margins to fall despite the drop in feedstocks costs. Increases in fourth-quarter refined product demand and refining earnings were insufficient to offset the previous nine months of poor financial results. Both upstream and downstream profits for foreign petroleum also declined. However, foreign operations continued as the most profitable sector of FRS company operations.

Perhaps the most dramatic financial development in 1992 was the effect of the adoption of a new standard to account for postretirement benefits other than pensions. All at once, many companies recognized a cumulative liability for health and certain other benefits which in the aggregate nearly offset all FRS profits from ongoing operations. Many companies throughout the economy were affected by the new financial reporting requirements. The adoption, by itself, virtually eliminated the net income of the For tune 500 group of industrial companies. Adjusting for the cumulative liability caused a $\$ 70$-billion offset in profits for this group of companies leaving a residual net profit of only $\$ 10$ million. $^{3}$

This report reviews the effects of developments in energy markets and the economy from the financial performance perspective of the FRS companies in 1992. Chapter 2 presents an overview of the sources of income and cash flow, and uses of funds including investment patterns across lines of business. Chapter 3 examines income and non-income taxes for the FRS companies. Chapters 4 and 5 review aspects of the FRS companies' performance in their petroleum operations in 1992 from both a geographical and functional perspective. The first of these two chapters reviews performance for upstream operations and the second for downstream operations. Chapter 6 examines developments among the FRS companies in energy sources other than petroleum. Appendix A describes the structure of the FRS system and Appendix B presents detailed statistical tables. A glossary provides key definitions.

\footnotetext{
${ }^{1}$ The companies that reported to the FRS system for the years 1977 through 1992 are listed in Appendix A.

${ }^{2}$ Unless otherwise noted, energy industry price and quantity data are from Energy Information Administration, Monthly Energy Review August 1993, DOE/EIA-0035(93/08) (Washington, DC, August 1993).

${ }^{3}$ Fortune (April 19, 1993), p. 174.
} 


\section{The FRS Companies in the U.S. Economy and Energy Markets}

Major energy companies annually report to the Energy Information Administration (EIA) on Form ELA-28. These company reports include data and information on their financial and operating developments. For the reporting year 19\$2, 25 companies filed this information. ${ }^{a}$ The FRS companies occupy a major position in the U.S. ${ }^{b}$ economy. In 1992, their sales were equal to 20 percent of the $\$ 2.4$ trillion in sales by Fortune's list of the 500 largest U.S. industrial corporations, ${ }^{c}$ and their assets were equal to 18 percent of those of the Fortune 500 companies. Of the top 25 industrial companies (based on sales) on the Fortune 500 list in 1992, 9 were FRS companies.

The reporting companies engage in a wide range of business activities, but their most important activities are in the energy sector. About 84 percent, or $\$ 405$ billion, of allocated operating revenues were derived from energy sales. Nearly all of these sales involve petroleum (Figure 1). (For purposes of this report, petroleum is defined to include natural gas.)

\section{Figure 1. Operating Revenues by Line of Business for FRS Companies, 1981-1992}

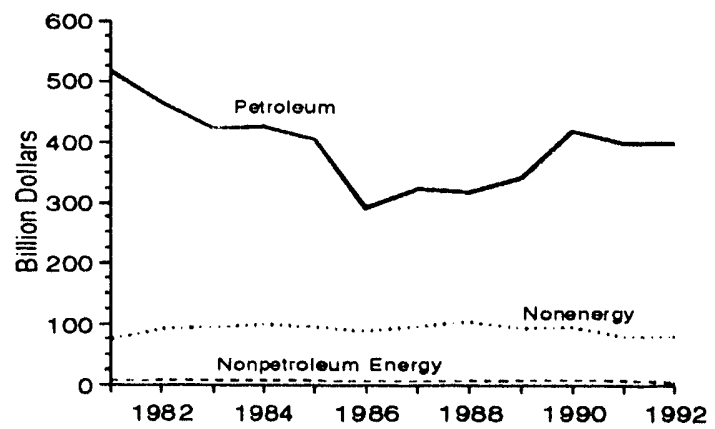

Source: Energy Information Administration, Form EIA-28.
In 1992, the FRS companies accounted for 54 percent of total U.S. crude oil and natural gas liquids production, 45 percent of U.S. natural gas production, and 69 percent of U.S. refinery capacity (Figure 2). The bulk of the FRS companies' assets, as well as their new investments, is devoted to sustaining various aspects of petroleum production, processing, transportation, and marketing. Nonenergy business accounted for about 16 percent, or $\$ 80$ billion, of the FRS companies' allocated revenues in 1992.

\section{Figure 2. FRS Companies' Share of U.S. Energy Production and Refinery Capacity, 1981-1992}

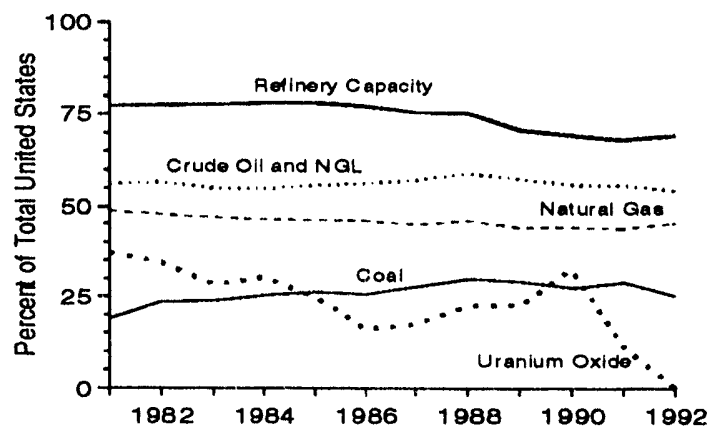

Source: See Appendix B, Table B1.

Relative to petroleum, production of nonpetroleum energy by the FRS companies is not large. The combined operating revenues of coal, nuclear, and nonconventional energy operations of the FRS companies totaled $\$ 5$ billion in 1992, or only 1 percent of allocated revenues. Nonetheless, the FRS companies are significant participants in the coal market. For example, the FRS companies produced 25 percent of all U.S. coal in 1992. However, they no longer produce uranium oxide domestically. Aggregate nonpetroleum energy activities contributed little to the total profits of the FRS companies in 1992.

an addition to the data pro vided by the detailed statistical tables in Appendix B and in the appendices of previous versions of this report, aggregate time series data from Form EIA-28 are available in a special post embargo report covering the period 1974 through 1980 . See Energy Information Administration, Energy Company Development Patterms in the Post-mbargo Era, Vol. 1 and Vol. 2, DOE/EIA-039. See also a special analysis of energy developments in the $1980^{\circ}$ s published in Energy Information Administration, Performance Profiles of Major Energy Producers 1990, Volume 2, DOE/EIA-0206(90). Additionally, aggregate time series data from Form EIA-28 for 1974 through 1992 can be obtained from the EIA (see contacts, p. ii), on paper or diskette.

"For purposes of this report, the term "United States" typically includes the 50 States, the District of Columbia, Puerto Rico, and the U.S. Virgin Islands.

The Fortune 500 is a directory of the 500 largest U.S. industrial companies, ranked by company total sales, as published annually by Fortune magazine. To be listed, companies must obtain a majority of their sales revenues from manufacturing/mining, which includes oil production and refining. Financial and operating statistics for the Fortune 500 are therefore suitable for comparison with related FRS measures. Since all but one FRS company have sales revenues sufficient to qualify, the few exclusions of FRS companies from the Fortune 500 are due principally to foreign ownership or sales in non-manufacturing sectors. All Fortune 500 statistics used in this boxed discussion have been adjusted by the addition of those FRS companies excluded from the original Fortune directories. These companies are Anadarko, BP America, Eruron, and Union Pacific. 


\section{Key Financial Developments in 1992}

\section{Corporate Profitability}

In 1992, new financial reporting requirements greatly reduced the reported profitability of large publiclytraded corporations in the United States. Financial Accounting Standard No. 106, "Employer's Accounting for Postretirement Benefits Other Than Pensions" (SFAS 106) was implemented. ${ }^{4}$ Prior to SFAS 106, deferred compensation to employees (including, particularly, rights to continuing health care coverage after retirement) could be expensed on a pay-as-you-go basis. The new standard requires that the current value of any deferred obligation be recorded on a current basis. Moreover, past obligations must be summed and recorded as adjustments to corporate financial performance.

This new standard of accounting appears to have had a greater impact on companies' financial statements in terms of the "bottom line" than any other accounting principle ever implemented. Table 1 summarizes selected financial items for FRS companies and other large industrial companies as represented by the Standard \& Poor's 400 group. ${ }^{5}$

Reported profitability, as measured by return on equity (net income as a percent of stockholders' equity), fell to near zero for both groups of companies in 1992 (Figure 3). FRS companies in 1992 undertook to recognize previously unrecorded cost commitments amounting to more than $\$ 11$ billion. For non-FRS Standard \& Poor's companies, the total was about $\$ 60$ billion. Fortune magazine's survey of the 500 largest U.S. industrial corporations revealed that SFAS 106 adjustments totaled $\$ 70$ billion for the group as a whole, leaving a reported net profit of only $\$ 10$ million for the year $1992 .^{6}$

Table 1. Comparison of Selected Financial Items for FRS Companies and the S\&P 400, 1992

\begin{tabular}{|c|c|c|c|c|}
\hline \multirow[b]{2}{*}{ Selected Financial Items } & \multicolumn{2}{|c|}{ All FRS Companies } & \multicolumn{2}{|c|}{ Non-FRS S\&P $400^{a}$} \\
\hline & $\begin{array}{c}1992 \\
\text { (billion dollars) }\end{array}$ & $\begin{array}{c}\text { Percent Change } \\
1991-1992\end{array}$ & $\begin{array}{c}1992 \\
\text { (billion dollars) }\end{array}$ & $\begin{array}{c}\text { Percent Change } \\
1991-1992\end{array}$ \\
\hline \multicolumn{5}{|l|}{ Income Statement } \\
\hline Operating Revenues $\ldots \ldots \ldots \ldots \ldots \ldots$ & 472.8 & 1.9 & $2,280.3$ & 0.9 \\
\hline Operating Expenses $\ldots \ldots \ldots \ldots \ldots \ldots$ & -449.5 & 2.6 & $-2,090.5$ & 0.7 \\
\hline Operating Income $\ldots \ldots \ldots \ldots \ldots \ldots$ & 23.3 & -10.4 & 189.8 & 2.2 \\
\hline Other Income ${ }^{b} \ldots \ldots \ldots \ldots \ldots$ & -12.9 & $\ldots$ & -131.7 & $\ldots$ \\
\hline Income Taxes $\ldots \ldots \ldots \ldots \ldots \ldots \ldots \ldots$ & -8.6 & -18.8 & -44.9 & -0.5 \\
\hline Net Income $\ldots \ldots \ldots \ldots \ldots \ldots$ & 1.8 & -88.0 & 13.2 & -77.3 \\
\hline \multicolumn{5}{|l|}{ Net Income, Excluding Cumulative Effect } \\
\hline of Accounting Changes . . . . . . . . . . & 12.5 & -13.0 & 72.7 & 12.5 \\
\hline Cash Flow from Operations ... & 44.8 & -6.4 & 209.9 & 4.0 \\
\hline
\end{tabular}

aS\&P 400 excluding FRS companies. Fifteen FRS companies belong in the S\&P 400 group.

bOther Income includes other revenue and expense, extraordinary items, and accounting changes.

$-=$ Not meaningful.

Sources: FPS companies: Energy Information Administration, Form ElA-28. S\&P 400: Standard \& Poor's Compustat Services, Inc.

\footnotetext{
${ }^{4}$ Financial Accounting Standards Board, Statement of Financial Accounting Standards, No. 106 (Norwalk, CT, December 1990).

${ }^{5}$ The S\&P 400 is a well recognized data base that includes 400 of the largest U.S. industrial companies. In 1992, 15 of the FRS companies were included in the S\&P 400 . Financial statistics for the S\&P 400 were obtained by accessing Compustat, a service of Standard \& Poor's Inc.

${ }^{6}$ Fortune (April 19, 1993), p. 174.
} 
Figure 3. Return on Equity for FRS Companies and the S\&P 400, 1973-1992

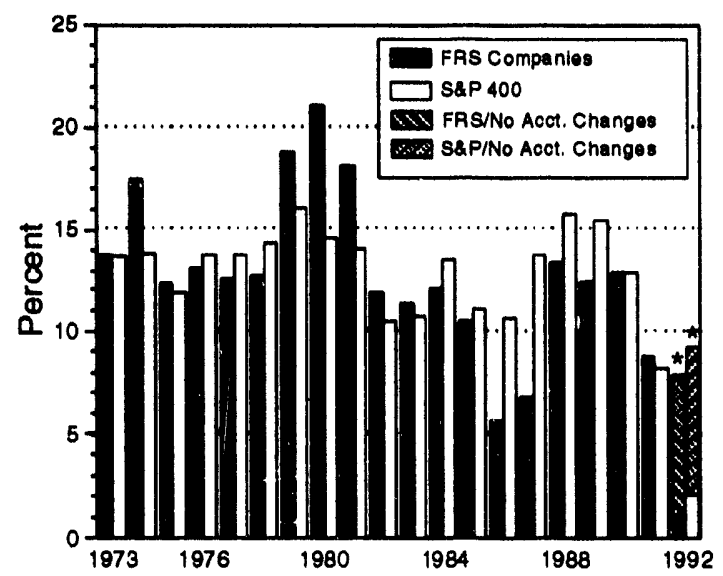

"Excluding cumulative effect of accounting changes.

Source: FRS Companies: Energy Information Administration, Form EIA-28. S\&P 400: Standard \& Poor's Compustat Services, Inc.

Net income for FRS companies excluding adjustments for all unusual items, including accounting changes, equaled $\$ 15.1$ billion in 1992, down 4 percent relative to 1991 (Table 2). The weak profit performance for FRS companies in 1992 followed a downturn in net income in 1991. Generally, for both years, financial improvements in oil and gas production were more than offset by lower downstream petroleum results.

The year 1992 was especially poor for petroleum refining and petroleum product marketing, both in the United States and abroad. Overall profitability of the FRS companies' worldwide refining/marketing operations in 1992 fell to its lowest level in at least 15 years (Figure 4). Net income, excluding unusual items, declined 72 percent between 1991 and 1992 in U.S. refining/marketing operations and nearly 50 percent in foreign refining/marketing operations (Table 2). Even though crude oil input prices, on average, were lower in 1992 than in 1991, sluggish growth in many industrialized economies had a negative effect on margins. The worst financial results were achieved in domestic refining and marketing operations where, in the face of declining product prices, manufacturing and distribution costs rose, in part in response to new product quality requirements designed to protect urban air quality. Figure 4. Rates of Return by Line of Business for
FRS Companies, 1977-1992

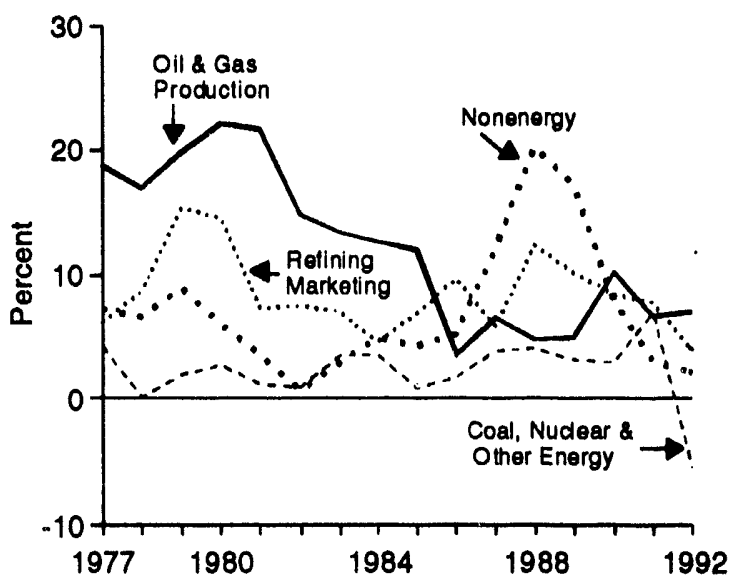

Note: Net income contribution divided by net investment in place.

Source: Energy Information Administration, Form ElA-28.

Excluding unusual items, net income from lines of business outside petroleum was, on balance, up slightly. A rebound in the performance of diversified nonenergy businesses more than offset the adverse effects of lower prices for oil from Canadian tar sands and for coal.

In aggregate, these developments caused profitability from worldwide petroleum operations to fall to their lowest level since 1986 (Table 3). Within petroleum, the decline was greatest in foreign operations, but worldwide rates of return for foreign operations were still highest among all of FRS corporate operations. The profitability of nonpetroleum operations, mainly in chemical manufacture, was markedly less than the average profitability for worldwide petroleum operations in 1992.

\section{Corporate Restructuring}

Insights into FRS company efforts to improve future profitability can be gained by examining ongoing actions to restructure business operations and to allocate new investment expenditures. In 1992, most of the FRS companies undertook restructuring efforts. Over two-thirds of the FRS companies noted in their

\footnotetext{
${ }^{7}$ Unusual items are composed of gains and charges recognized in a company's income statement which are of a non-recurring nature and generally unrelated to current operations. These items include litigation settlements, gains and losses from large divestitures of assets, provisions for the cost of restructuring, and provisions for reserves for future liabilities.
} 
Table 2. Contributions to Net Income by Line of Business for FRS Companies, 1991-1992

\begin{tabular}{|c|c|c|c|c|c|c|}
\hline \multirow[b]{2}{*}{ Line of Business } & \multicolumn{3}{|c|}{ Net Income } & \multicolumn{3}{|c|}{ Net Income Excluding Unusual Items } \\
\hline & 1991 & 1992 & $\begin{array}{c}\text { Percent Change } \\
1991-1992\end{array}$ & 1991 & 1992 & $\begin{array}{c}\text { Percent Change } \\
\text { 1991-1992 }\end{array}$ \\
\hline & \multicolumn{2}{|c|}{ (million dollars) } & & \multicolumn{2}{|c|}{ (million dollars) } & \\
\hline $\begin{array}{l}\text { Petroleum } \\
\text { U.S. Petroleum } \\
\text { Production } \ldots \ldots \ldots \ldots \ldots \ldots \ldots \\
\text { Refining/Marketing } \ldots \ldots \ldots \ldots \ldots \\
\text { Pipelines } \ldots \ldots \ldots\end{array}$ & $\begin{array}{r}5,050 \\
903 \\
1,984 \\
7,939\end{array}$ & $\begin{array}{r}5,588 \\
-213 \\
2,080 \\
7,483\end{array}$ & $\begin{array}{r}10.7 \\
- \\
4.8 \\
-5.7\end{array}$ & $\begin{array}{l}5,510 \\
1,916 \\
2,000 \\
9,428\end{array}$ & $\begin{array}{r}6,421 \\
542 \\
2,033 \\
9,024\end{array}$ & $\begin{array}{r}16.5 \\
-71.7 \\
1.7 \\
-4.3\end{array}$ \\
\hline 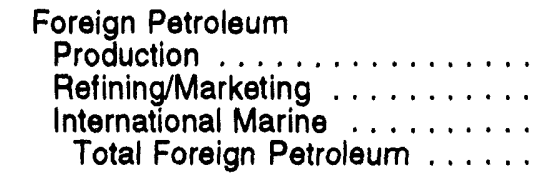 & $\begin{array}{r}5,375 \\
4,115 \\
285 \\
9,775\end{array}$ & $\begin{array}{r}4,657 \\
2,234 \\
-22 \\
6,869\end{array}$ & $\begin{array}{c}-13.4 \\
-45.7 \\
- \\
-29.7\end{array}$ & $\begin{array}{r}4,452 \\
3,823 \\
285 \\
8,560\end{array}$ & $\begin{array}{r}5,002 \\
1,982 \\
-21 \\
6,963\end{array}$ & $\begin{array}{r}12.4 \\
-48.2 \\
-. \\
-18.7\end{array}$ \\
\hline Total Petroleum . . . . . . . . . . . . & 17,714 & 14,352 & -19.0 & 17,988 & 15,987 & -11.1 \\
\hline Coal . . . . . . . . . . . . . . & 584 & -486 & -- & 528 & 441 & -16.5 \\
\hline Nuclear and Other Energy . . . . . . . & 81 & 50 & -38.3 & 81 & 130 & 60.5 \\
\hline Nonenergy . . . . . . . . . . . . . . & 1,632 & 1,223 & -25.1 & 3,095 & 3,609 & 16.6 \\
\hline Total Allocated .. & 20,011 & 15,139 & -24.3 & 21,696 & 20,167 & -7.0 \\
\hline Nontraceables and Eliminations .... & $-5,332$ & $-13,382$ & - & $-5,981$ & $-5,103$ & -- \\
\hline Consolidated Net Income $\theta^{a} \ldots \ldots$ & 14,679 & 1,757 & -88.0 & 15,715 & 15,064 & -4.1 \\
\hline
\end{tabular}

aThe total amount of unusual items was $-\$ 1,036$ million and $-\$ 13,307$ million in 1991 and 1992 , respectively.

-- = Not meaningful.

NA $=$ Not applicable.

Note: In petroleum, sum of components may not equal total due to nontraceables and eliminations.

Source: Energy Information Administration, Form ElA-28.

Table 3. Rates of Return by Line of Business for FRS Companies, 1986-1992 (Pcrcent)

\begin{tabular}{|c|c|c|c|c|c|c|c|}
\hline Line of Business & 1986 & 1987 & 1988 & 1989 & 1990 & 1991 & 1992 \\
\hline Petroleum ........ & 5.5 & 6.2 & 7.3 & 6.7 & 9.5 & 7.0 & 5.6 \\
\hline $\begin{array}{l}\text { U.S. Petroleum ................ } \\
\text { Oil and Gas Production } \ldots \ldots \ldots \\
\text { Refining/Marketing } \ldots \ldots \ldots \ldots \\
\text { Pipelines } \ldots \ldots \ldots \ldots \ldots\end{array}$ & $\begin{array}{r}3.0 \\
0.8 \\
4.5 \\
13.2\end{array}$ & $\begin{array}{r}4.9 \\
4.1 \\
2.9 \\
12.8\end{array}$ & $\begin{array}{r}6.3 \\
2.8 \\
14.7 \\
9.6\end{array}$ & $\begin{array}{r}5.8 \\
2.9 \\
11.5 \\
10.2\end{array}$ & $\begin{array}{r}7.9 \\
8.5 \\
5.1 \\
11.2\end{array}$ & $\begin{array}{r}4.9 \\
5.1 \\
2.0 \\
10.7\end{array}$ & $\begin{array}{r}4.4 \\
5.9 \\
-0.4 \\
8.4\end{array}$ \\
\hline $\begin{array}{l}\text { Foreign Petroleum } \ldots \ldots \ldots \ldots \\
\text { Oil and Gas Production } \ldots \ldots \ldots \ldots \\
\text { Refining/Marketing } \ldots \ldots \ldots \ldots \\
\text { International Marine } \ldots \ldots \ldots \ldots\end{array}$ & $\begin{array}{r}12.8 \\
11.6 \\
16.3 \\
5.3\end{array}$ & $\begin{array}{r}9.5 \\
12.4 \\
4.7 \\
-3.6\end{array}$ & $\begin{array}{r}9.9 \\
9.2 \\
11.6 \\
6.8\end{array}$ & $\begin{array}{r}8.7 \\
8.9 \\
8.0 \\
12.4\end{array}$ & $\begin{array}{l}12.5 \\
13.1 \\
11.2 \\
11.7\end{array}$ & $\begin{array}{r}11.0 \\
9.1 \\
14.6 \\
15.6\end{array}$ & $\begin{array}{r}7.9 \\
8.2 \\
7.8 \\
-1.2\end{array}$ \\
\hline Coal & 2.7 & 5.1 & 6.7 & 5.0 & 3.3 & 8.7 & -9.3 \\
\hline Nuclear and Other Energy & -0.8 & 0.5 & -2.5 & -2.3 & 2.6 & 2.8 & 1.8 \\
\hline Nonenergy & 5.1 & 12.2 & 20.3 & 17.3 & 7.8 & 2.9 & 2.1 \\
\hline
\end{tabular}

Note: Rate of return measured as contribution to net income/net investment in place.

Source: Energy Information Administration, Form EIA-28. 
1992 annual reports to shareholders that they had taken charges against income for the purposes of selectively reducing their operations. Restructuring efforts were focused mainly on U.S. petroleum operations. Fourteen companies reported restructuring charges for their domestic upstream operations. Eleven of eighteen FRS refiners reported restructuring charges for their domestic downstream operations. The overriding purpose of the U.S. upstream charges was to reduce operating costs and, in refining/marketing, to consolidate operations in order to focus on areas of greatest competitive advantage. The impetus for upstream restructuring appears rooted in the lack of frontier areas available for exploration in the United States. Re-evaluations of U.S. downstream operations were occasioned by the higher costs and increased capital expenditures attending the Clean Air Act Amendments of 1990 and earlier environmental legislation.

The latest wave of restructuring by FRS companies differed from the major downsizing efforts largely initiated in the mid-1980's. ${ }^{8}$ Earlier efforts tended to be directed toward reducing the scope of business activities through the divestiture of entire businesses, particularly those outside petroleum and chemicals. For example, the petroleum and chemical share of the FRS companies' allocated net investment in place rose from 81 percent in 1983 to 90 percent in 1989 but was only 1 percentage point higher in 1992. By contrast, recent efforts have been largely directed to consolidating operations in core businesses, with the exception of coal operations.

In 1991 and 1992, five FRS companies either sold or announced plans to sell all or a significant portion of their U.S. coal operations. These divestitures followed BP America's sale of their coal assets in 1989 and 1990. As of December 31, 1991, DuPont transferred its Consolidation Coal Company unit to the joint venture, Consci Energy, half-owned by DuPont and half-owned by RWE AG of Germany. In 1992, Occidental Petroleum treated its Island Creek Coal subsidiary as a discontinued operation as did Sun Company with their coal subsidiary. Both of these coal-producing subsidiaries were subsequently sold in 1993. Shell Oil sold its U.S. coal operations to Zeigler Coal in 1992. Burlington Resources sold most of its coal properties to a limited partnership in 1992, retaining a production royalty. Most of the divested coal reserves, apart from Burlington Resources, are located in the higher-cost Eastern region of the United States. However, the bulk of the divested reserves and associated facilities are relatively close to export points. This locational feature may have enhanced their value as future sources of supply to European markets.

The area of greatest improvement in financial performance among the FRS companies' lines of business in 1992 was also the focus of greatest retrenchment. Excluding unusual items, net income from U.S. oil and gas production rose $\$ 0.9$ billion, to $\$ 6.4$ billion, compared with 1991's results (Table 2). ${ }^{9}$ Although natural gas prices made a remarkable recovery in 1992, nearly doubling between February and October, ${ }^{10}$ this development served primarily to offset lower revenues stemming from lower oil prices.

The main source of improvement in the FRS companies' U.S. oil and gas operations was to be found on the cost side. Retrenchment was evident in ongoing operations as well as exploratory activity, resulting in sharp declines in U.S. production costs and exploratory expenses. The long-term effects of the i RS companies' restructuring are, perhaps, most evident in their employment counts: the number of employees reported by the FRS companies in 1992 was nearly 50 percent fewer than in 1982 (Figure 5).

Aside from domestic upstream petroleum operations, the greatest improvement in net income for FRS companies was derived from their nonenergy operations. For more than a decade the nonenergy sector of FRS operations has been the object of major restructuring efforts. Major improvement has been in the "other nonenergy" segment rather than in chemical operations. Other nonenergy encompasses a variety of businesses including (but not limited to) minerals,

\footnotetext{
${ }^{8}$ See the 1985 through 1990 editions of this report for extended discussions of various aspects of the FRS companies' restructuring.

${ }^{9}$ Line-of-business profit measures should be distinguished from measures which reflect company-wide results because the former reflect only allocated income, expense, and asset items. Two measures of income are presented: operating income and contribution to net income. Operating income by line of business is similar in concept to the operating income measure for total company operations. It is the net of operating revenues and operating expenses (including depreciation, depletion, and amortization) for a line of business. Contribution to net income equals operating income plus income from unconsolidated affiliates and gains on disposal of property, plant, and equipment (PP\&E) less income taxes imputed to the line of business and excludes certain non-allocable items, primarily interest expense. Interest expense is the principal source of difference between a companywide net income figure and line-of business contributions to net income (see Appendix A for further discussion). Line-of-business rates of return are based on historical costs and measure ex post average profitability, not marginal or prospective rates of return.

${ }^{10}$ Unless otherwise noted, energy industry price and quantity data in this chapter are from Energy Information Administration, Monthly Energy Review September 1993, DOE/EIA-0035(93/09)(Washington, DC, September 1993).
} 


\section{Figure 5. Number of Employees of FRS Companies, 1981-1992}

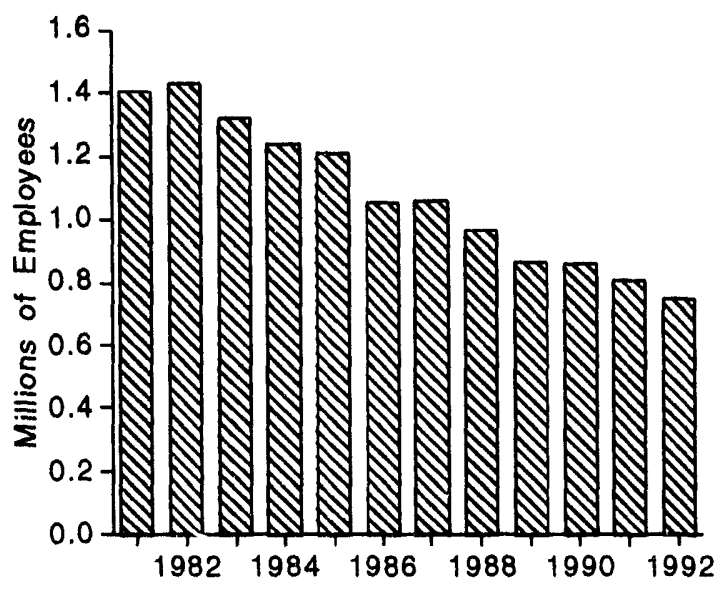

Sources: Company annual reports to shareholders.

primary metals, transport, real estate, agricultural products, and household goods.

The FRS companies' restructuring actions reduced the asset base in the other nonenergy segment by ovir 50 percent between 1983 and 1989. During this period, except for chemicals, most FRS companies sold or otherwise disposed of businesses which were unprofitable or were not integral to their longterm investment strategies. Businesses that showed noticeable increases in operating income between 1991 and 1992 included BP America's nutrition business, for which a combination of operating cost reductions and new products yielded more than a doubling in income; Union Pacific's railroad system, which registered its highest income in history with traffic up in most commodity groups; and the steel operations of USX, who reported that "results in 1992 reflected the favorable effects of savings from cost reduction programs, [and] higher utilization of raw steel and raw material production capability. ..." ${ }^{11}$

\section{Figure 6. Revenues and Operating Expenses for the Chemical Segment for FRS Companies, 1981-1992}

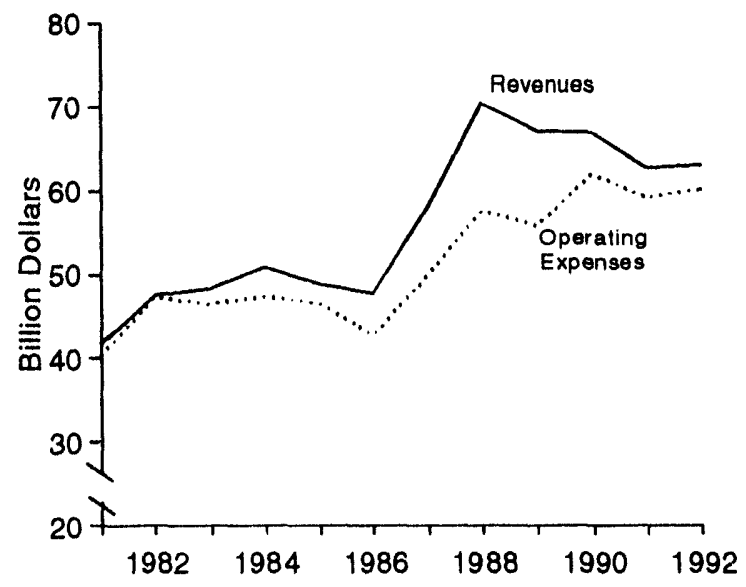

Sources: 1981-1986: Energy Information Administration, Form EIA-28. 1987 through 1992: company annual reports to shareholders.

The most important component of the nonenergy sector is chemical manufacture. These operations, however, were not a source of increased earnings in 1992 (Table 4). In the second half of the 1980's, due to economic growth in the industrial sectors of the world and to lower raw material input costs following the oil price crash of 1986, chemical profits rose rapidly. In response to increased profits, chemical production capacity became a target of investment, not only for the FRS companies but also for chemical manufacturers worldwide. Added capacity, together with weakened economic growth beginning in 1990, first in the United States and then in other industrial nations, had a dampening effect on prices, particularly for petrochemicals. The sharp fall in income which began in 1990 moderated in 1992. Due to a greater increase in operating expenses than in revenues (Figure 6), ${ }^{12}$ operating income from the FRS companies' chemical operations in 1992 was down from 1991 (Table 4). At $\$ 4.0$ billion, income in 1992 was only about a third of the peak levels attained by the FRS companies' chemical operations in 1988-1989.

\footnotetext{
"British Petroleum Company PLC, BP Annual Reports and Accounts 1992, p. 29. Union Pacific Corporation, 1992 Annual Report, pp. 4-5. USX Corporation, Securities and Exchange Commission Form 10-K, p. S-22.

${ }^{12}$ For FRS purposes, separate reporting of income for chemical and other nonenergy segments was discontinued beginning with the 1987 reporting year. However, the disclosures of chemical segment revenues and operating income made by the FRS companies in their annual reports to shareholders closely track, in the aggregate, the comparable disclosures in the Form EIA-28 from 1981 through 1986 . Thus the public disclosures of chemical segment revenue and operating income were utilized for 1987 through 1992. Revenues and operating income for the other nonenergy segment after the 1986 reporting year were obtained by subtracting the publicly disclosed chemical segment values from the nonenergy line-of-business values reported on Form EIA-28. It should be noted that the results for chemicals are qualitatively unchanged if DuPont, the largest FRS chemical producer, is excluded.
} 
Table 4. Operating Income in Chemicals and Other Nonenergy Segments for FRS Companies, 1991-1992

\begin{tabular}{|c|c|c|c|}
\hline Segment & 1991 & 1992 & $\begin{array}{c}\text { Percent Change } \\
1991-1992\end{array}$ \\
\hline & \multicolumn{2}{|c|}{ (million dollars) } & \\
\hline Operating Income, Excluding Unusual Items & & & \\
\hline $\begin{array}{l}\text { Chemicals }{ }^{2} \ldots \\
\text { Other Nonenergy } \\
\ldots \ldots\end{array}$ & $\begin{array}{r}4,232 \\
342\end{array}$ & $\begin{array}{l}3,993 \\
1,167\end{array}$ & $\begin{array}{r}-5.6 \\
241.2\end{array}$ \\
\hline
\end{tabular}

Sources: Energy Information Administration, Form ElA-28, except for chemicals segment operating income which was compiled from company annual reports to shareholders.

\section{Corporate Liquidity and Uses of Funds}

Cash flow from operations, ${ }^{13}$ together with funds obtained from the capital markets through borrowing and the issuance of stock, provide most of the funds for capital expenditures, dividends, and other uses of capital. With the exception of 1990, when the effects of Iraq's invasion of Kuwait led to a sharp, but short-lived, rise in income and cash flow, the FRS companies' cash flow has been in the range of $\$ 44$ billion to $\$ 48$ billion per year since 1986. Cash flow in 1992, at $\$ 44.8$ billion (Table 5), was at the lower end of this range. Contributions to cash flow from the lines of business exhibited a pattern roughly similar to that of income across lines of business. Oil and gas production, the most important source of cash flow, and the other nonenergy segment registered modest increases in cash flow. However, these improvements were more than offset by reduced cash flow generated by downstream petroleum operations, reflecting the deterioration in refined product markets both in the United States and abroad in 1992.

Table 5. Line-of-Business Contributions to Pretax Cash Flow for FRS Companies, 1991-1992

\begin{tabular}{|c|c|c|c|}
\hline Contribution to Pretax Cash Flow & 1991 & 1992 & $\begin{array}{c}\text { Percent Change } \\
1991-1992\end{array}$ \\
\hline & \multicolumn{2}{|c|}{ (billion dollars) } & \\
\hline \multicolumn{4}{|l|}{ Petroleum } \\
\hline Oil and Gas Production . . . . . . . . & 39.2 & 40.3 & 2.8 \\
\hline Refining, Marketing, and Transport & 16.4 & 12.4 & -24.6 \\
\hline Coal and Other Energy $\ldots \ldots \ldots \ldots \ldots$ & 1.6 & 1.2 & -25.1 \\
\hline Chemicals $\ldots \ldots \ldots \ldots \ldots \ldots$ & 7.8 & 7.8 & -0.5 \\
\hline Other Nonenergy $\ldots \ldots \ldots$ & 1.4 & 2.3 & 60.8 \\
\hline Nontraceable $\ldots \ldots \ldots \ldots \ldots \ldots$ & -1.6 & -1.8 & -. \\
\hline Total Contribution to Pretax Cash Flow ${ }^{2}$ & 64.8 & 62.0 & -4.3 \\
\hline Current Income Taxes $\ldots \ldots \ldots \ldots \ldots$ & -12.7 & -11.5 & -9.2 \\
\hline Other $($ Net $) \ldots \ldots \ldots \ldots \ldots \ldots \ldots \ldots$ & -4.2 & -5.7 & -. \\
\hline Cash Flow from Operations & 47.8 & 44.8 & -6.4 \\
\hline
\end{tabular}

aDefined as the sum of operating income, DD\&A, and dry hole expense. Excludes unusual items.

$--=$ Not meaningful.

Note: Sum of components may not equal total due to independent rounding. Percent changes were calculated from unrounded data.

Source: Energy Information Administration, Form ElA-28.

\footnotetext{
${ }^{13}$ Cash is defined as currency, demand deposits, and interest-bearing assets of less than 30 days maturity. Generally, cash flow from operations is computed by adding to (subtracting from) net income those cost (revenue) items which did not actually involve an outlay (receipt) of cash. The largest of these non-cash items is the cost of depreciation, depletion, and amortization (DD\&A). Also, outlays (receipts) of cash which were recognized as non-cash items in previous income statements (e.g., provisions for a legal settlement taken as a charge against income in a previous year but not actually paid until the current year) are subtracted from (added to) net income in computing cash flow. Lastly, changes in working capital (excluding cash) due to operations are subtracted.
} 
Other potential sources of funds include net corporate borrowing and net issuance of new equity securities. On balance, more debt was retired than was raised in 1992 (Table 6), no doubt reflecting an effort by FRS companies to take advantage of the drop in long-term interest rates. In 1992, rates on 10-year U.S. Treasury securities were the lowest in 20 years while rates on high-grade corporate bonds were at a 15-year low. ${ }^{14}$

Debt reduction has been a goal evident among the FRS companies since the mid-1980's. Following significant takeovers and takeover defenses in the first half of the 1980 ' $\mathrm{s}^{15}$ the FRS companies' overall debt load increased sharply. Increased debt led to an ever-greater call on cash flow for interest payments, leaving less cash available for reinvestment and dividends.

In recent years, the combination of restrained growth in debt and generally lower interest rates noticeably reduced the portion of the FRS companies' cash flow going for interest payments (Figure 7). In 1992, the FRS companies' interest expense was down 10 percent from 1991. Sales of equity for large, established companies is a much less important external source of funds, compared with long-term debt. In 1992, funds raised from equity security offerings rose from an all-time low of $\$ 497$ million in 1991 to $\$ 3.4$ billion (Table 6). Companies leading the rebound in equity financing included Amerada Hess, Unocal, and USX.

Table 6. Sources and Uses of Cash for FRS Companies, 1991-1992

\begin{tabular}{|c|c|c|c|}
\hline Sources and Uses of Cash & 1991 & 1992 & $\begin{array}{c}\text { Percent Change } \\
\text { 1991-1992 }\end{array}$ \\
\hline & \multicolumn{2}{|c|}{ (billion dollars) } & \\
\hline $\begin{array}{l}\text { Main Sources of Cash } \\
\text { Cash Flow from Operations } \ldots \ldots \ldots \ldots \ldots \ldots \ldots \ldots \ldots \\
\text { Proceeds from Long-term Debt } \ldots \ldots \ldots \ldots \ldots \ldots \ldots \ldots \\
\text { Proceeds from Disposals of Assets } \ldots \ldots \ldots \ldots \ldots \ldots \\
\text { Proceeds from Equity Security Offerings } \ldots \ldots \ldots \ldots \ldots\end{array}$ & $\begin{array}{r}47.8 \\
22.1 \\
9.4 \\
0.5\end{array}$ & $\begin{array}{r}44.8 \\
24.7 \\
7.3 \\
3.4\end{array}$ & $\begin{array}{r}-6.4 \\
11.9 \\
-22.3 \\
600.2\end{array}$ \\
\hline $\begin{array}{l}\text { Main Uses of Cash } \\
\text { Additions to Investment in Place } \ldots \ldots \ldots \ldots \ldots \ldots \ldots \ldots \\
\text { Reductions in Long-term Debt } \ldots \ldots \ldots \ldots \ldots \ldots \ldots \ldots \ldots \ldots \ldots \ldots \ldots \ldots \\
\text { Dividends to Shareholders } \ldots \ldots \ldots \ldots \ldots \ldots \ldots \ldots \ldots \ldots \\
\text { Purchase of Treasury Stock } \ldots \ldots \ldots \ldots \ldots \ldots \ldots\end{array}$ & $\begin{array}{r}46.4 \\
18.4 \\
13.5 \\
2.0\end{array}$ & $\begin{array}{r}42.0 \\
25.3 \\
13.5 \\
0.8\end{array}$ & $\begin{array}{r}-9.6 \\
37.3 \\
0.2 \\
-58.2\end{array}$ \\
\hline Other Investment and Financing Activities, Net & -1.2 & 0.4 & -- \\
\hline Net Change in Cash and Cash Equivalents ......... & -1.7 & -1.0 & $\cdots$ \\
\hline
\end{tabular}

$-=$ Not meaningful.

Note: Sources minus Uses plus Other Investment and Financing Activities (Net) may not equal Net Change in Cash and Cash Equivalents due to independent rounding. Percent changes were calculated from unrounded data.

Source: Energy Information Administration, Form EIA-28.

${ }^{14}$ Economic Report of the President January 1993, p. 428.

${ }^{15}$ In late 1981, DuPont acquired Conoco (an FRS respondent) which, for FRS purposes, was treated as occurring on January 1, 1982. In 1982, USX (formerly U.S. Steel) acquired Marathon Oil (an FRS respondent), while two other FRS respondents, Occidental Petroleum and Cities Service, merged. Intra-FRS mergers in 1984 included Chevron-Gulf, Mobil-Superior Oil, and Texaco-Getty Oil. The value of these mergers totaled $\$ 47$ billion. In 1985, Phillips Petroleum and Unocal fended off takeover attempts which resulted in large increases in their debt. 
Figure 7. Financial Ratios for FRS Companies, 1981-1992

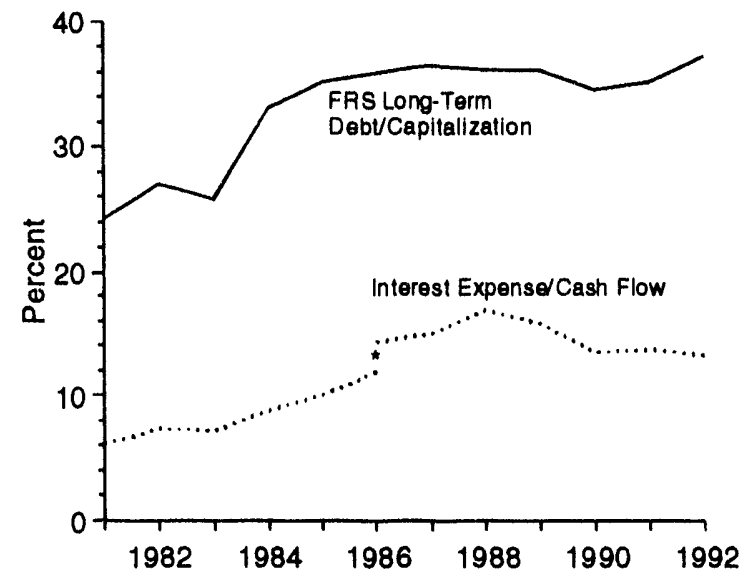

"Due to changes in accounting standards, cash flow from operations is on a working capital basis for 1981-1986 and on a cash basis for 1986-1992.

Source: Energy Information Administration, Form EIA-28.

\section{Targets of Investment}

Capital expenditures totaled $\$ 42$ billion in 1992, down 10 percent from the prior year (Table 7), and, excluding the effects of mergers and acquisitions, declined for the first time since 1986 (Figure 8). ${ }^{16}$ Domestic oil and gas production was the primary focus of investment cutbacks in 1992.

From the oil price collapse of 1986 through 1991, the FRS companies' annual capital expenditures for U.S. oil and gas production were generally flat, ranging from $\$ 11$ billion to $\$ 13$ billion. ${ }^{17}$ The exception was 1988 , when Tenneco sold its petroleum assets for $\$ 8$ billion, mainly to other FRS companies, while at the same time the amount of Federal Outer Continental Shelf lease acreage offered and awarded more than doubled. In 1992, the FRS companies reduced their capital outlays for U.S. oil and gas production to $\$ 8.8$ billion, 27 percent below 1991 expenditures, the lowest level in 15 years.

\section{Figure 8. Additions to Investment in Place and Value of Acquisitions and Mergers for FRS Companies, 1974-1992}

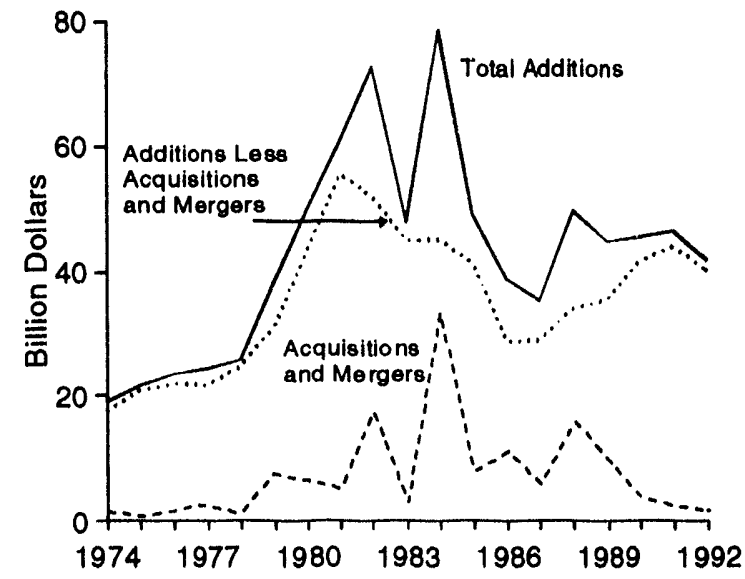

Sources: Energy Information Administration, Form EIA-28, and company filings of Securities and Exchange Commission Form 10K.

All categories of U.S. oil and gas production expenditures were subjected to cutbacks in 1992. Acreage acquisition and exploratory drilling evidenced the largest reductions, indicating a lessened interest in frontier activity. The only area in the United States evidencing a heightened level of activity by the FRS companies was development drilling of onshore natural gas fields. This increase in developmental gas drilling follows a surge in exploratory gas well completions and was further stimulated by sharp increases in wellhead natural gas prices during 1992.

Perhaps most indicative of a lessened commitment by many FRS companies to U.S. oil and gas production has been their recent sale of domestic oil and gas properties. From 1977 through 1989, the FRS companies as a group were generally net purchasers of proven oil and gas reserves. That is, the FRS companies' total purchases of oil and gas reserves exceeded their total sales of oil and gas reserves, which means that, on balance, the FRS companies were gaining reserves from non-FRS companies. Over this period, net purchases by

\footnotetext{
${ }^{16}$ To the extent possible, capital outlays are measured by additions to investment in place, which are defined as additions to property plant, and equipment (PP\&E) plus additions to investment and advances. In 1992, additions to PP\&E accounted for 97 percent of capital outlays so measured. However, because additions to investments and advances were not collected for some FRS segments prior to 1981, capital outlays are sometimes measured by additions to PP\&E. Also, in comparisons with the S\&P 400, this latter measure is used since the S\&P 400 data base does not provide an item comparable to additions to investment and advances.

${ }^{17}$ Energy Information Administration, Form ElA-28.
} 
Table 7. Additions to Investment in Place by Line of Business for FRS Companies, 1991-1992

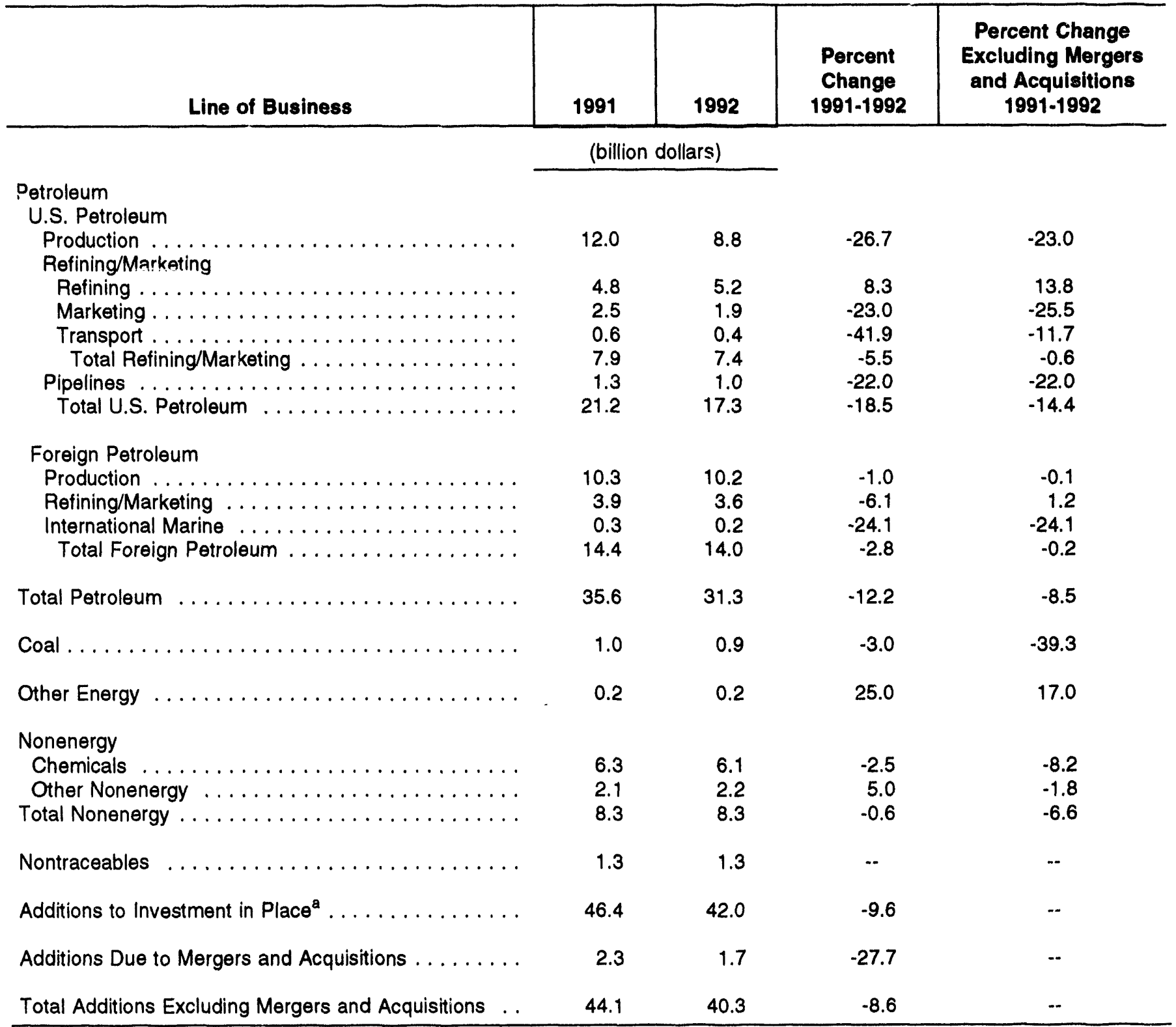

${ }^{a}$ Measured as additions to PP\&E plus additions to investments and advances.

- = Not meaningful.

Note: Sum of components may not equal total due to independent rounding. Percent changes were calculated from unrounded data.

Source: Energy Information Administration, Form EIA-28.

the FRS companies annually averaged 335 million barrels of oil equivalent. In 1990, the long-standing net purchase position of the FRS companies reversed, with an aggregate net sale of 81 million barrels of oil equivalent. Net sales of FRS oil and gas reserves in the United States rose sharply in 1991, to 460 million barrels, and rose sharply again in 1992, to 613 million barrels. Although net sales in the 1990's represented only about 3 percent of the FRS companies' U.S. oil and gas reserves, this trend nevertheless indicates that, at the margin, the FRS companies have been reducing their investment commitment to this area. ${ }^{18}$

${ }^{18}$ Energy Information Administration, Form EIA-28. 
Between 1986 and 1991, while FRS companies' capital expenditures for U.S. oil and gas production were generally holding steady, expenditures for foreign oil and gas production increased. Apart from two large acquisitions in Canada, ${ }^{19}$ the bulk of the growth in FRS companies' expenditures abroad was directed toward the North Sea, Southeast Asia, and Pacific Rim areas. Most of the growth in the FRS companies' foreign capital expenditures occurred between 1986 and 1989, when expenditures more than doubled, to $\$ 12$ billion. In the 1990's, foreign annual capital expenditures have held steady at about $\$ 10$ billion.

Despite the apparent stability in expenditures, the composition of foreign spending shifted toward development in 1992. Expenditures for acquisition of exploratory acreage and exploratory drilling abroad declined by 50 percent and 39 percent, respectively, while overall development expenditures were up 5 percent (Appendix B, Table B21). In the context of low and uncertain oil prices, overseas investment emphasis has also shifted somewhat away from prospecting frontier areas to development of earlier explored locales and sustaining production from maturing areas such as the North Sea. Increased investment in the Middle East is evident as risks affecting the role of foreign investment there have eased, encouraging greater participation by FRS and other companies in these markets. Some FRS companies have focused additional expenditures in the South Pacific, particularly in Indonesia, for the purpose of developing the deliverability of gas supplies, in liquified form, to industrial areas in the Pacific Rim. Though many companies have announced plans for developing resources in the former Soviet Union, only nominal amounts of investment have been committed at this time.

A majority of the refiners among the FRS companies reported increased capital expenditures for U.S. refining operations in 1992. The 14-percent increase in these expenditures (excluding the effect of mergers and acquisitions) reflected continued upgrading of the lightproduct capability of refiners and increased capital expenditures for facilities to meet environmental quality standards. Companies reporting significant increases in capital expenditures for U.S. refining included Mobil, who completed an upgrading and expansion of lightproduct capability at its Beaumont, Texas refinery, and Amerada Hess, who is constructing a 90,000 barrel-perday fluid catalytic cracking unit at its U.S. Virgin Islands refinery in order to increase its production of gasoline. ${ }^{20}$

Although the FRS reporting system does not collect data on capital expenditures for environmental quality and remediation, available data indicate that FRS companies' capital expenditures for these purposes continued to increase in 1992. In a recent report, the National Petroleum Council estimated that pollution abatement expenditures for U.S. refining operations were $\$ 3$ billion in 1992, about double the $\$ 1.5$ billion reported by the U.S. Department of Commerce for $1991 .^{21}$ A somewhat lesser, but nonetheless steep, increase in environmentally-related capital expenditures was reported by the 15 FRS companies who made this disclosure in their Securities and Exchange Commission Form $10-\mathrm{K}$. For these companies, environmentallyrelated capital expenditures for all lines of business rose 22 percent between 1991 and 1992, to $\$ 3.3$ billion, and accounted for 13 percent of their total additions to property, plant, and equipment (excluding mergers and acquisitions). In 1991, the comparable share was 9 percent.

Capital expenditures for foreign refining/marketing in 1992 , at $\$ 3.6$ billion, were little changed from the peak expenditures of $\$ 3.9$ billion in 1991. Despite their apparent stability, notable shifts in these expenditures occurred among the FRS companies. Exxon reported an increase of $\$ 358$ million in its foreign refining/marketing expenditures ${ }^{22}$ which reflected investments in Italy and other parts of Europe for largely environmentally-related purposes, additional service stations in Southeast Asia, and continued work on an expansion of their refinery in Thailand. DuPont reported an increase in capital expenditures for foreign refining/marketing of $\$ 68$ million, ${ }^{23}$ adding

\footnotetext{
19. In 1988, Amoco acquired Dome Petroleum and, in 1989, Exxon acquired Texaco Canada.

${ }^{20}$ Mobil Corporation, 1992 Annual Report, p. 24, and Amerada Hess Corporation, Securities and Exchange Cor umission Form 10-K, p. 3.

${ }^{21}$ National Petroleum Council, U.S. Petroleum Refining, Volume III: Financial and Facilities Appendices (Washington, DC, August 1993).

${ }^{22}$ Exxon, 1992 Annual Report, p. 14.

${ }^{23}$ E.I. DuPont de Nemours, DuPont Data Book 1992, p. 44.
} 
downstream processing capacity at their U.K. refinery and expanding its marketing outlets in Eastern Europe. In contrast, Mobil sold its Norwegian fuel operations and Coastal Corporation reported that its Aruba refinery (purchased in 1989) was running at target levels and capital expenditures had declined.

Mergers and acquisitions have often been an expeditious and convenient means of implementing corporate growth and diversification. However, in 1992, the FRS companies' emphasis on restructuring and consolidation of current lines of activity generally led to a reduced interest in mergers and acquisitions. Capital expenditures for mergers and acquisitions in 1992 totaled $\$ 1.7$ billion (Table 7), the lowest level in 15 years (Figure 8). ${ }^{24}$

The largest-valued acquisition among the FRS companies in 1992 was, ironically, a result of Shell Oil's divestiture of their U.S. coal operations. Part of the compensation received by Shell Oil for the sale of their coal subsidiaries to Zeigler Coal was a 25-percent interest in Zeigler Coal, valued at $\$ 348$ million (Table 8). ${ }^{25}$ Including purchases of proved oil and gas reserves, oil and gas production was the primary target of FRS companies' merger and acquisition activity in 1992 , accounting for 41 percent of the $\$ 1.7$ billion of capital expenditures due to mergers and acquisitions.

\footnotetext{
${ }^{24}$ Figure 8 and Table 7 show the value of property, plant, and equipment and investments and advances added to the companies' books as a result of acquisitions rather than the value of the transactions. The reported, or purchase, value of an acquisition shown in Table 7 can include effects on working capital, long-term liabilities, and other values which would not add to the acquiring company's investment base.

${ }^{25}$ Shell Oil Company, Securities and Exchange Commission Form 10-K, p. 40.
} 
Table 8. Value of Mergers, Acqulstions, and Related Transactions by FRS Companies, 1992 (Million Dollars)

\begin{tabular}{c|c|c}
\hline Line of Businese and Acquiring Company & Acquisition & $\begin{array}{c}\text { Reported Value } \\
\text { of Acquisition }\end{array}$ \\
\hline
\end{tabular}

U.S. Oil and Gas Production

Anadarko Petroleum . . . . . . . . . . . . . Purchase of producing properties (Texas) from 190 ARCO

Burlington Resources $\ldots \ldots \ldots \ldots \ldots \ldots$ Purchase of producing properties from Mobil

80

Anadarko Petroleum ................ Acquisition of Calley \& Fowler Production Co.

Foreign Oil and Gas Production

Purchase of Canadlan natural gas properties from

Sun

Purchase of Canadian oil and gas reserves from

Shell Canada

Coal

Shell Oil .

Acquisition of 25-percent interest in Zeigler Coal (part of the transaction involving Shell's sale of its coal properties to Zeigler Coal)

\section{U.S. Refining/Marketing}

Purchased Mobil stations in Houston

Undisclosed

Other Energy

Enron

Acquisition of 90.5 percent interest in Virginia

15 cogeneration plant from BTR PLC.

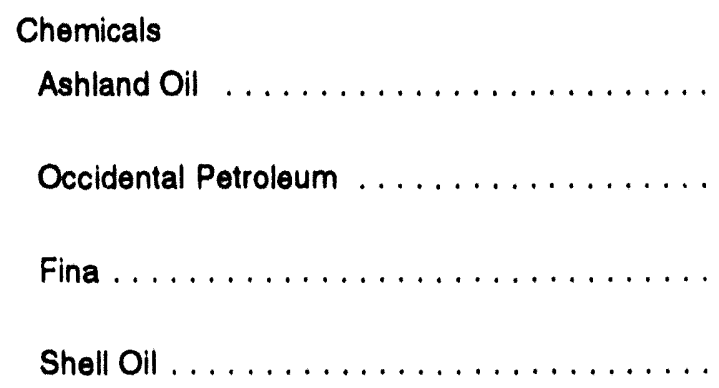

Acquisition of chemicals distribution business from Unocal

84

Acquistion of chemicals businesses from

84 Monsanto

Acquisition of high density polyethylene facility

Undisclosed

Acquisition of polyester resins business from

Goodyear Tire and Rubber

Undisclosed

Other Nonenergy

Union Pacific

Exchanged convertible preferred stock in Chicago

71 and Northwestern for 29.5 percent nonvoting equity interest in that company

Sources: Company annual reports to shareholders, Oil and Gas Investor (September 1992 and April 1993), and various issues of The Wall Street Journal. 


\section{Taxation}

In 1992, the worldwide annual tax liabilities of the FRS companies continued their long-term decline (Figure 9). ${ }^{26}$ Total taxes fell to $\$ 17.8$ billion, or by $\$ 1.8$ billion from 1991. The decrease resulted, to a large extent, from an increase in tax offsets from restructuring of petroleum operations and from poor market conditions in refining and marketing. The decrease in total tax liabilities was almost equally divided between foreign and U.S. income taxes (Figure 10). Severance taxes decreased slightly but other non-income taxes increased by an even greater amount, resulting in a net non-income tax increase of $\$ 0.2$ billion. The change in the composition and number of FRS companies from 1991 to 1992 affected aggregate tax liabilities negligibly.

\section{Figure 9. Worldwide Tax Liabilities for FRS Companies, 1981-1992}

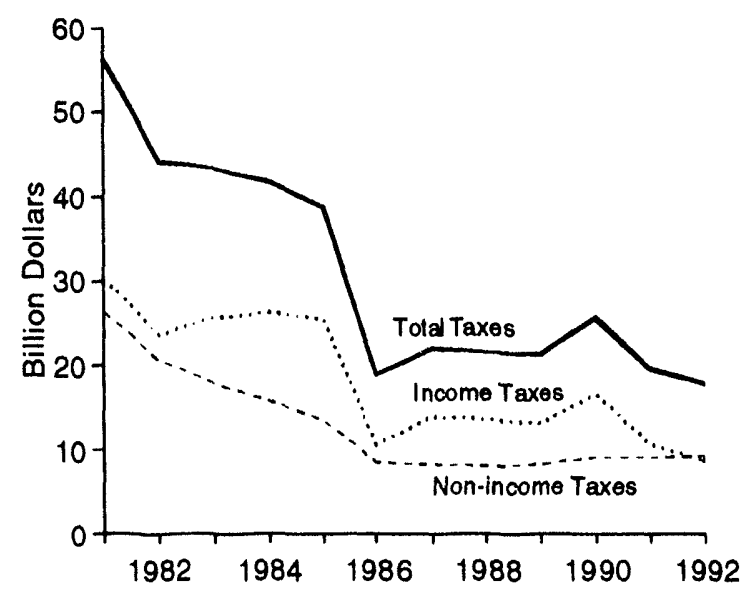

Note: Excludes foreign taxes other than income taxes. Source: Energy Information Administration, Form EIA-28.

\section{Figure 10. Worldwide Tax Liabilities for FRS Companies, 1991 and 1992}

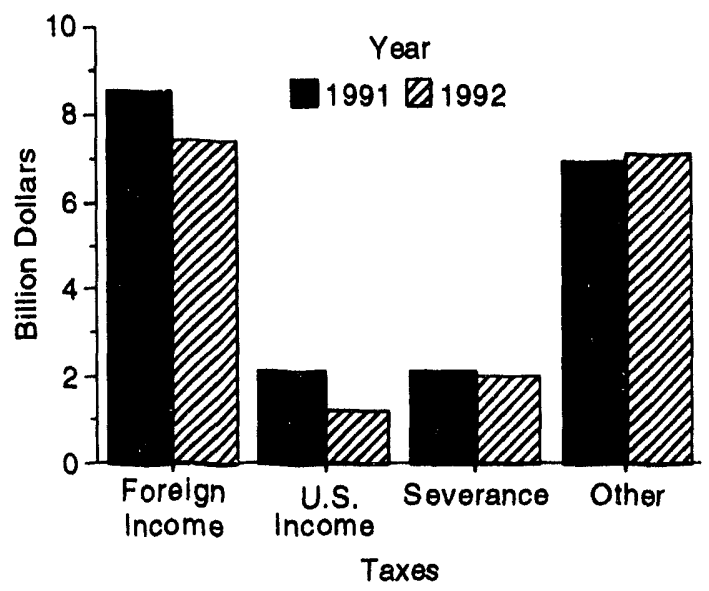

Note: Excludes foreign taxes other than income taxes. Source: Energy Information Administration, Form EIA-28.

\section{Income Taxes}

Worldwide income tax liabilities (current and deferred $)^{27}$ for the FRS companies amounted to $\$ 8.6$ billion in 1992, a decrease of 19 percent from a year earlier (Table 9). The decline for the FRS companies was substantially greater than the 0.5 -percent decline for the Standard and Poor's 400 (S\&P 400) group of U.S. industrial companies (Table 1). Nevertheless, average effective income tax rates for the two groups are about the same. The near equality is a result of the Tax Reform Act of 1986 (TRA86), and of sharp reductions in petroleum tax rates abroad at about the time TRA 86 was enacted.

\footnotetext{
${ }^{26}$ Worldwide taxes include both U.S. and foreign income taxes and U.S. non-income taxes. Foreign non-income taxes are not included since they are not collected by the FRS system for all lines of business.

${ }^{27}$ Current income taxes are those incurred and payable during the current period. Deferred taxes, although incurred during the current period, are payable at some future date. See Appendix A for a discussion of deferred taxes.
} 
Table 9. Income Tax Expense, Pretax Income, and Tax Shares for FRS Companies, 1990-1992

\begin{tabular}{|c|c|c|c|}
\hline Taxes and Pretax Income & 1990 & 1991 & 1892 \\
\hline & \multicolumn{3}{|c|}{ (billion dollars) } \\
\hline 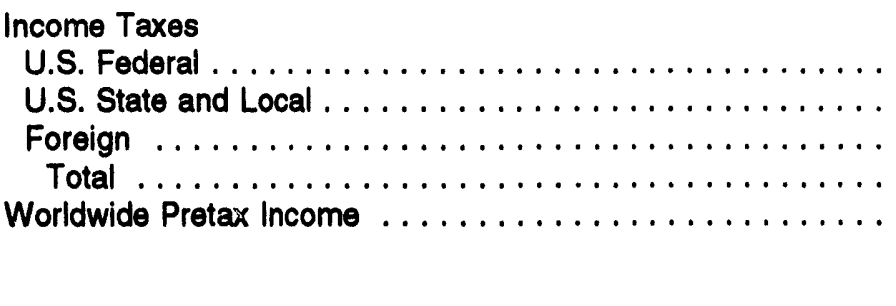 & $\begin{array}{r}5.5 \\
0.9 \\
10.1 \\
16.5 \\
37.5\end{array}$ & $\begin{array}{r}1.5 \\
0.6 \\
8.5 \\
10.6 \\
25.1 \\
\\
\text { (percent }\end{array}$ & $\begin{array}{r}0.4 \\
0.8 \\
7.4 \\
8.6 \\
22.5\end{array}$ \\
\hline 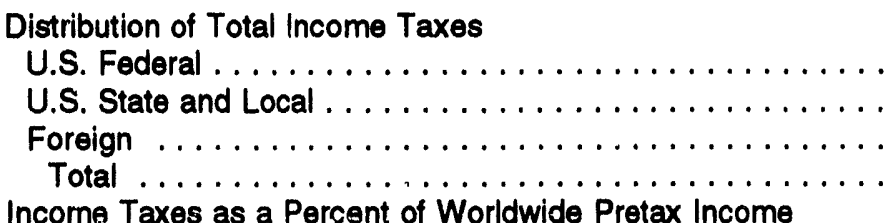 & $\begin{array}{r}33.1 \\
5.6 \\
61.3 \\
100.0\end{array}$ & $\begin{array}{r}14.1 \\
5.9 \\
80.0 \\
100.0\end{array}$ & $\begin{array}{r}5.0 \\
9.0 \\
85.9 \\
100.0\end{array}$ \\
\hline 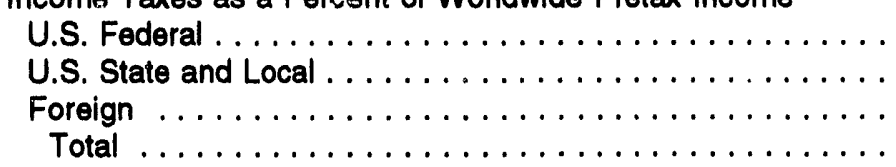 & $\begin{array}{r}14.6 \\
2.5 \\
27.0 \\
44.1\end{array}$ & $\begin{array}{r}6.0 \\
2.5 \\
33.8 \\
42.3\end{array}$ & $\begin{array}{r}1.9 \\
3.5 \\
32.9 \\
38.3\end{array}$ \\
\hline
\end{tabular}

Note: Sum of components may not equal total due to independent rounding.

Source: Energy Information Administration, Form ElA-28.

\section{United States}

U.S. income taxes (Federal, State and local) for the FRS companies fell to $\$ 1.2$ billion in 1992, the lowest level since at least 1974. In FRS upstream operations, higher natural gas prices and production increased income and generated an increase in income taxes of over $\$ 700$ million. However, the tax increase was tempered by an increase in tax offsets of the same magnitude (Tables 10 and 11). These offsets included adjustments for taxes paid in prior years, writedowns of assets, and restructuring charges such as severance pay and early disbursements of pensions.

Taxes on upstream operations were also low in 1992 because FRS companies rlaimed unusually large tax credits (so-called "Section 29" credits) for unconventional (or alternative) fuels. The credits for the FRS companies for that year increased to between $\$ 0.2$ billion and $\$ 0.3$ billion from about $\$ 0.1$ billion a year earlier. FRS companies received more than one-third of all 1992 unconventional fuels tax credits. ${ }^{28}$ Generally, the credits had applied to oil and gas from certain sands, shale, brine, and coal seams for wells drilled by the end of that year. In 1992, the credits were due to expire unless renewed by the Energy Policy Act of 1992, passed by the Congress in November 1992 (See Tax Provisions box). The Act renewed some credits, but not for oil and gas produced from wells drilled after 1992 for methane (gas) and in certain sands. The uncertainty concerning the potential extension contributed to an increase in coalbed methane drilling by FRS companies and other producers in 1992 and is reflected in their natural gas production data (Appendix B, Table B1).

A weak performance in the FRS companies' domestic refining and marketing segment also contributed to the overall reduction in U.S. income taxes in 1992. Income taxes allocated to those operations fell to $\$ 0.2$ billion in 1992 (Appendix B, Table B5) from $\$ 0.6$ billion a year earlier. Slow economic growth resulted in weak demand for refined products, which caused product prices and refining margins to fall. Pretax income fell by $\$ 1.2$ billion and, as a consequence, income taxes fell by $\$ 0.4$ billion.

\footnotetext{
${ }^{20}$ The credits are estimates based on data in Energy Information Administration Form ElA-28; company annual reports; and Office of Management and Budget, Budget of the United States Government, Fiscal Year 1994 (Washington, DC, 1993). Also, 1993 edition of the Budget.
} 


\section{Tax Provisions of the Energy Policy Act of 1992 of Special Interest to the Energy Industry}

\section{A. Alcohol Fuels}

The alcohol fuels provision extends the partial excise tax exemption for gasoline with at least 10 percent alcohol to mixtures with as little as 5.7 percent alcohol. The excise tax rates on these lower-level mixtures are prorated to maintain a constant subsidy level per gallon of alcohol, namely 54 cents per gallon (for ethanol) and 60 cents per gallon (for other alcohol), that is mixed with gasoline. The provision went into effect January 1, 1993.

\section{B. Alternative Fuels}

The alternative fuels provision extends the applicable time period for the so-called "Section 29 " tax credit as it applies to the production of some alternative (or nonconventional) fuels. The extension applies only to gas from biomass and to liquid, gaseous, or solid synthetic fuels produced from coal in facilities placed in service through 1996 (pursuant to a written binding contract in effect before 1996) and sold through the year 2007. Prior to the extension the years were 1992 and 2002, respectively. In the case of a facility that produces coke or coke gas, however, the extended dates apply only if the original use of the facility commenced with the taxpayer. The original dates continue to apply to all qualified alternative fuels not mentioned above. Those fuels include oil produced from shale and tar sands, and gas from geopressurized brine, Devonian shale, coal seams and tight formations.

\section{Trans-Alaska Pipeline Fund}

This provision permits taxpayers to use the Trans-Alaska Pipeline Trust Fund (TAPS Fund) credits against regular corporate income taxes, subject to certain limitations. This provision is effective for taxable years beginning after October 24, 1992.

\section{Alternative Minimum Tax for Independent Oil and Gas Producers}

This provision reduces the tax burden on independent oil and gas producers and royalty owners by repealing, for them, (1) the excess intangible drilling costs (IDCs) tax preference and (2) the excess percentage depletion tax preference for oil and gas for taxable years beginning after December 31, 1992. Excess preferences are preferences that are added back to the regular tax base in calculating income tax liabilities under the alternative minimum tax (AMT) system. The repeal of the excess IDC preference, however, may not result in more than a 30-percent (1993) or 40-percent (1994 and after) reduction in the amount of the taxpayer's alternative minimum taxable income.

Further, for independent oil and gas producers, the new law repeals the adjusted current earnings (ACE) adjustment of the corporate AMT for (1) IDCs paid or incurred in taxable years beginning after December 31, 1992, and (2) percentage depletion for oil and gas. The ACE concept applies to an expanded tax base for purposes of calculating the AMT.

The new law also suspends the alternative minimum tax energy deduction for taxable years beginning after December 31, 1992. The energy deduction is a deduction for certain IDC and depletion items. The energy deduction has the effect of reducing the taxpayer's income tax for AMT purposes. 
Table 10. Tax Offsets from Asset Writedowns and Other Speclal Charges for FRS Companies, 1990-1992 (Million Dollars)

\begin{tabular}{|c|c|c|c|}
\hline Line of Business & 1990 & 1991 & 1992 \\
\hline \multicolumn{4}{|l|}{$\begin{array}{l}\text { Petroleum } \\
\text { U.S. Petroleun: }\end{array}$} \\
\hline Production ...... & 296 & 371 & 1,147 \\
\hline Refining/Marketing & 485 & 373 & 332 \\
\hline Pipelines .......... & 10 & -16 & 23 \\
\hline Total U.S. Petroleum . . & 791 & 728 & 1,502 \\
\hline Foreign Petroleum & & & \\
\hline Production ...... & 122 & 140 & 510 \\
\hline$\ldots \ldots \ldots \ldots \ldots \ldots$ & -34 & 134 & 46 \\
\hline International Marine $\ldots .$. & 0 & 0 & 0 \\
\hline Total Foreign Petroleum $\ldots \ldots \ldots \ldots \ldots \ldots \ldots$ & 88 & 274 & 556 \\
\hline Total Petroleum & 879 & 1,002 & 2,058 \\
\hline 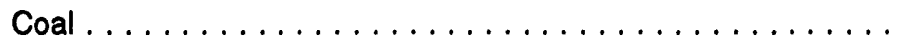 & 27 & -212 & 29 \\
\hline $\begin{array}{l}\text { Nuclear and Other Energy } \ldots \ldots \ldots \ldots \ldots \ldots \ldots \ldots \ldots \ldots \\
\text { Nonenergy }\end{array}$ & 0 & -4 & 3 \\
\hline Chemical $\ldots \ldots \ldots \ldots \ldots \ldots \ldots$ & -191 & 396 & 350 \\
\hline Other $\ldots \ldots \ldots \ldots$ & -133 & 428 & 182 \\
\hline Total Nonenergy . . & 324 & 824 & 532 \\
\hline Nontraceables .... . & 203 & 86 & 359 \\
\hline Total ...... & 1,433 & 1,696 & 2,981 \\
\hline
\end{tabular}

Note: Special charges for which tax offsets were not specified in individual company annual reports were estimated by applying the current U.S. Federal tax rate to those charges.

Source: Company annual reports to shareholders.

\section{Foreign}

Total foreign income taxes amounted to $\$ 7.4$ billion in 1992, a decrease of $\$ 1.1$ billion from a year earlier (Table 9). Foreign income taxes accounted for 86 percent of all income taxes in 1992 (Table 9). This was the fourth consecutive year of increase and the largest share since at least 1974. Total foreign income taxes typically exceed total domestic income taxes by large amounts even though pretax income explicitly allocated to lines of business in the two geographical areas are frequently similar. Foreign tax rates generally exceed U.S. rates, even though the differential has narrowed considerably over the past several years. ${ }^{29}$ The $\$ 1.1$-billion decrease in foreign income taxes in 1992 consisted of a \$1.4-billion decrease from foreign petroleum operations and a \$0.3-billion increase that could not be traced to any particular foreign activity (Tables 9 and 11). Changes in tax offsets accounted for only $\$ 0.3$ billion of the $\$ 1.4$-billion decrease, with the remainder originating from price, cost, and volume changes. The $\$ 1.4$-billion decrease was almost equally divided between the production and refining/marketing segments, while tax changes in the international marine segment were virtually nil.

Upstream operations have always generated more pretax income and tax liabilities for the FRS companies than have the other foreign petroleum segments. Taxes on foreign upstream operations fell to $\$ 5.9$ billion in 1992 (Table 12). This was in marked contrast to the virtually constant level of production taxes in the United States. About two-thirds of this decrease was from an increase in tax offsets, principally from asset writedowns and restructuring (Table 11). The remaining third resulted from a combination of price decreases for both crude oil and natural gas.

${ }^{29}$ See, for example, Energy Information Administration, Average Effective Corporate Income Tax Rates for Petroleum Operations, 1977-1989, DOE/EIA-0550 (Washington, DC, November 1991). 
Table 11. Change in Income Tax Expense from 1991 to 1992, by Source (Million Dollars)

\begin{tabular}{|c|c|c|c|}
\hline Line of Business & Tax Offsets & Other Sources ${ }^{a}$ & All Sources \\
\hline \multicolumn{4}{|l|}{ Petroleum } \\
\hline $\begin{array}{l}\text { S.S. Petroleum } \\
\text { Production } \ldots \ldots \ldots \ldots \ldots \ldots \ldots \ldots \ldots \ldots \ldots \ldots \ldots\end{array}$ & -776 & 770 & -6 \\
\hline Refining/Marketing $\ldots \ldots \ldots \ldots \ldots \ldots \ldots \ldots \ldots \ldots \ldots \ldots$ & 41 & -433 & -392 \\
\hline Pipelines $\ldots \ldots \ldots \ldots \ldots \ldots \ldots \ldots \ldots \ldots \ldots$ & -39 & -33 & -72 \\
\hline \multicolumn{4}{|l|}{ Foreign Petroleum } \\
\hline Production $\ldots \ldots \ldots \ldots \ldots \ldots \ldots \ldots \ldots \ldots$ & -370 & -247 & -617 \\
\hline Refining/Marketing $\ldots \ldots \ldots \ldots \ldots \ldots \ldots \ldots$ & 88 & -825 & -737 \\
\hline International Marine $\ldots \ldots \ldots \ldots \ldots \ldots \ldots$ & 0 & -8 & -8 \\
\hline Total Foreign Petroleum $\ldots \ldots \ldots \ldots \ldots \ldots \ldots$ & -282 & $-1,080$ & $-1,362$ \\
\hline Total Petroleum . . . . . . . . . . . . . . . . . . . & $-1,056$ & -786 & $-1,842$ \\
\hline Coal $\ldots \ldots \ldots \ldots \ldots \ldots \ldots \ldots \ldots \ldots$ & -241 & 5 & -236 \\
\hline Nuclear and Other Energy $\ldots \ldots \ldots \ldots \ldots \ldots \ldots \ldots$ & -7 & 21 & 14 \\
\hline \multicolumn{4}{|l|}{ Nonenergy } \\
\hline Chemical $\ldots \ldots \ldots \ldots \ldots \ldots \ldots \ldots \ldots \ldots$ & 46 & n.a. & n.a. \\
\hline Other $\ldots \ldots \ldots \ldots \ldots \ldots \ldots \ldots \ldots \ldots \ldots$ & 246 & n.a. & n.a. \\
\hline Total Nonenergy . . . . . . . . . . . . . . . . . . . . . . & 292 & 196 & 488 \\
\hline Nontraceables $\ldots \ldots \ldots \ldots \ldots \ldots \ldots \ldots \ldots \ldots$ & -273 & -144 & $c_{-417}$ \\
\hline Total $\ldots \ldots \ldots \ldots \ldots \ldots \ldots \ldots \ldots \ldots$ & $-1,285$ & -708 & $-1,993$ \\
\hline \multicolumn{4}{|l|}{$\begin{array}{l}{ }^{a} \text { Calculated as the difference between the other two columns. } \\
\text { bIncludes an adjustment of }-\$ 10 \text { million for eliminations. } \\
\text { cIncludes an adjustment of }-\$ 4 \text { million for eliminations. } \\
\text { n.a. = Not available. }\end{array}$} \\
\hline
\end{tabular}

Foreign downstream operations generated taxes of $\$ 1$ billion in 1992, a decline of $\$ 0.7$ billion from a year earlier (Tables 11 and 12). Relatively stagnant economies resulted in weak product demand, and product prices which declined more rapidly than crude oil prices. The result was a decrease in operating and pretax incomes, and, consequently, in income tax expense. Changes in tax offsets were relatively small and did not greatly affect tax liabilities. Tax changes in the international marine segment, the smallest of all of the foreign petroleum segments by any measure, were inconsequential.

The FRS reporting system requires companies to allocate foreign income taxes to six geographical areas. In 1992, current income taxes accounted for nearly all foreign income taxes, since deferred taxes were slightly negative (Table 13). The relative importance of the various areas typically changes slowly over time since it reflects the diversification of foreign sources of crude oil and natural gas supplies.
The only significant foreign geographical area changes in income taxes in 1992 were for Canada and the European member countries of the Organization for Economic Cooperation and Development. These changes probably reflect a combination of crude oil and natural gas price changes and tax rate changes, since production volumes changed little (Appendix B, Table B37).

\section{FRS and Indusiry Effective Tax Rates}

In 1992, the worldwide effective income tax rates for the FRS companies and the S\&P $\mathbf{4 0 0}$ group, based on conbined current and deferred taxes, each fell by about 4 percentage points, reaching historic or near historic lows of about 38 percent. The rates for the two groups of companies differed from each other by only twotenths of a percentage point in contrast to the wide differences in most years prior to that time (Figure 11, Part A). 
Table 12. Income Tax Expense, Pretax Income and Effective Tax Rates: U.S., Foreign, and Consolidated for FRS Companies by Line of Business, 1990-1992

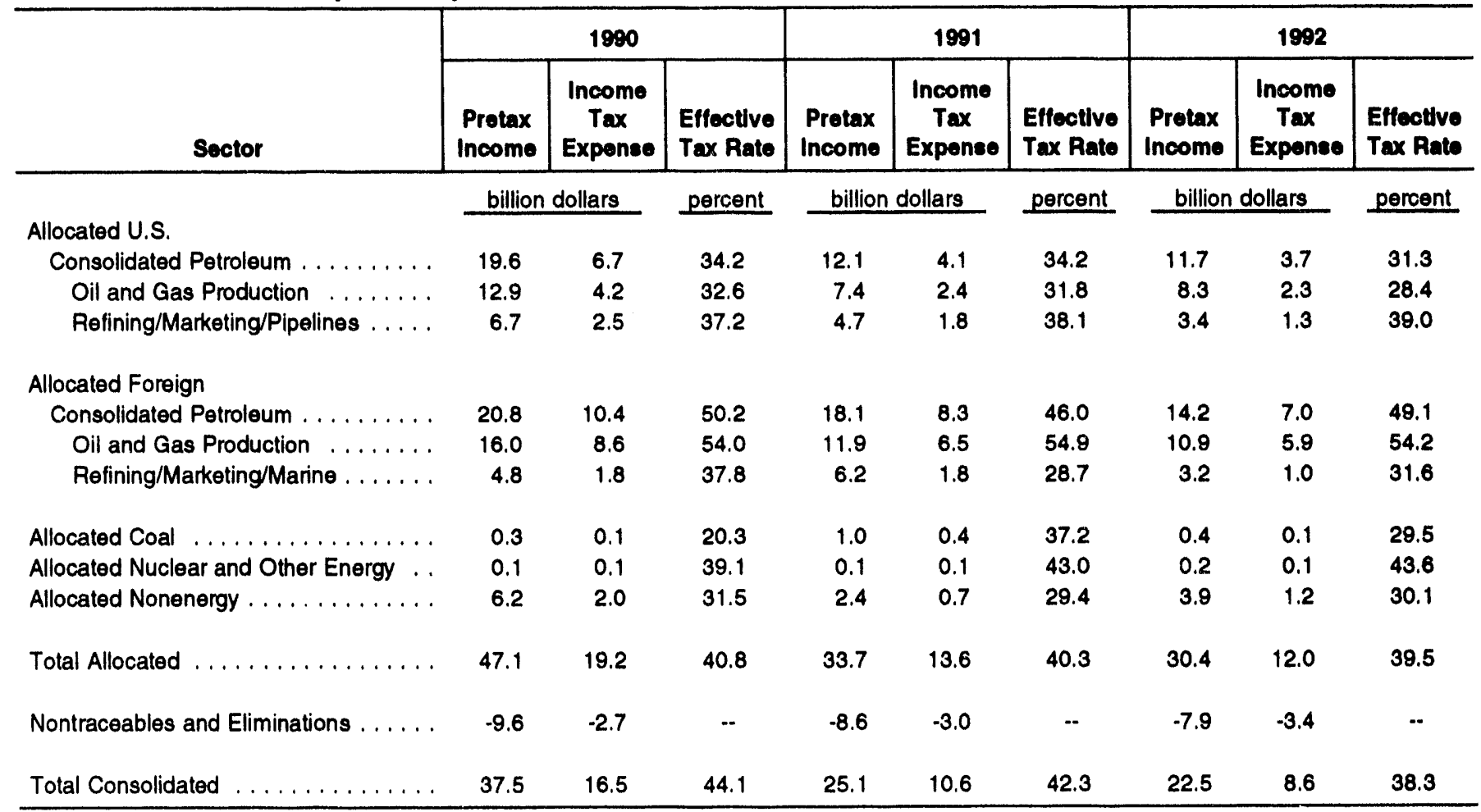

-. = Not meaningful.

Note: Sum of dollar value of components may not equal total due to independent rounding. Effective tax rates are calculated from unrounded data.

Source: Energy Information Administration, Form EIA-28.

Figure 11. Worldwide Effective Income Tax Rates for FRS Companies and S\&P 400, 1981-1992
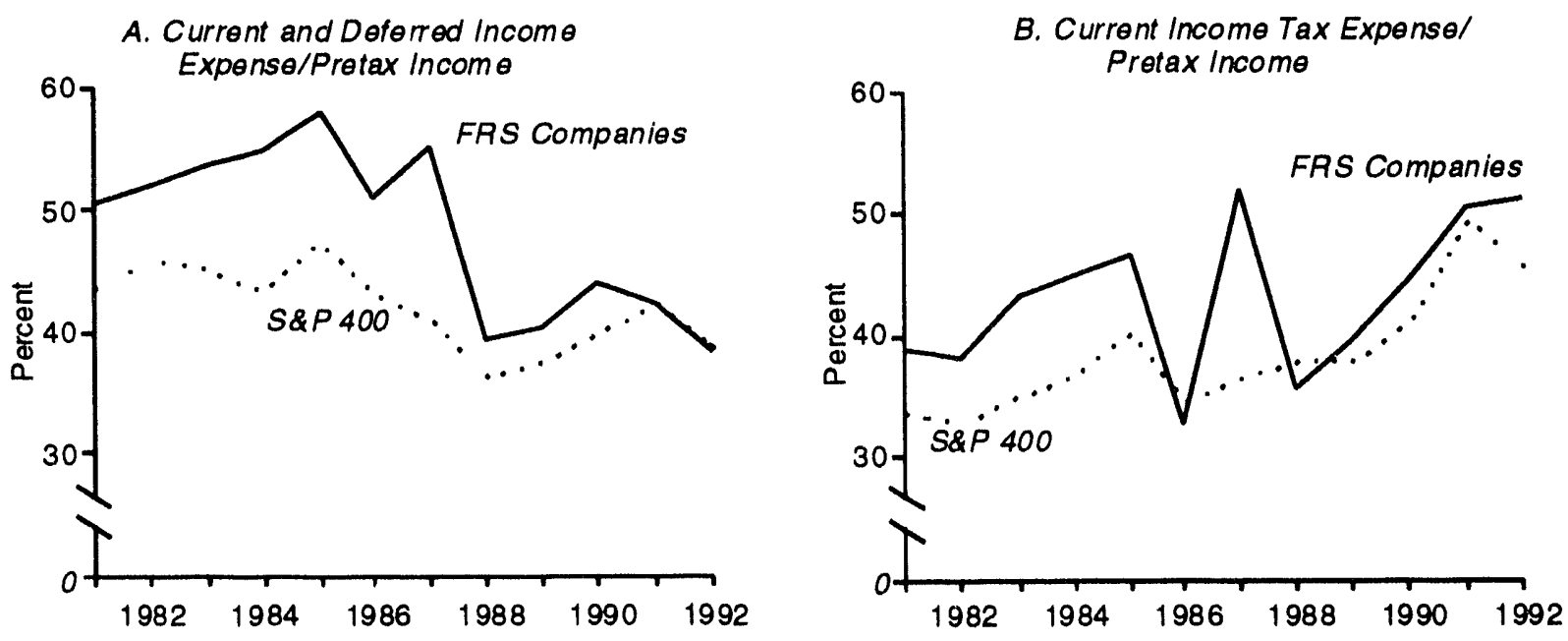

Source: FRS Companies: Energy Information Administration, Form EIA-28. S\&P 400: Standard and Poor's Compustat Services, Inc. 
Table 13. Composition of Income Tax Expense for FRS Companies, 1990-1992

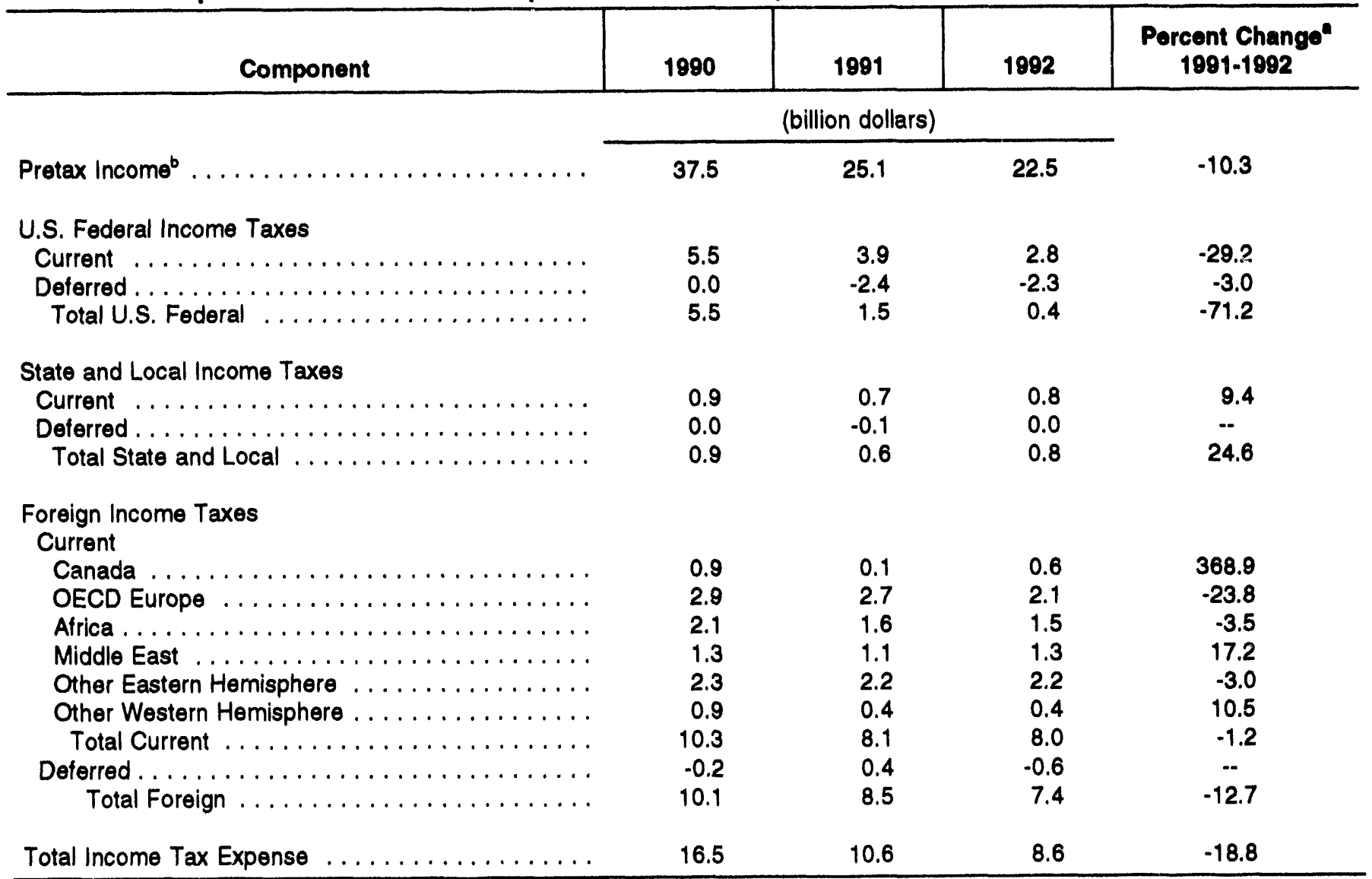

aBased on unrounded data.

Includes minority interest in income; excludes extraordinary items and cumulative effect of accounting changes.

-. = Not meaningful.

Note: Sum of components may not equal total due to independent rounding.

Source: Energy Information Administration, Form EIA-28.

The effective ate for the worldwide operations of the FRS companies (as well as for the S\&P 400 companies) has historically been substantially lower when only current income taxes are considered and deferred income taxes are excluded (Figure 11, Part B). This relationship changed dramatically beginning in 1990 for the FRS companies (and in 1988 for the S\&P 400 group) when deferred taxes turned negative for the first time. ${ }^{30}$ In 1992, deferred taxes amounted to a negative
$\$ 2.9$ billion (Table 14), and the worldwide effective tax rate based only on current income taxes exceeded the rate based on combined current and deferred taxes by nearly 13 percentage points. Because of a recent change in accounting for income taxes, the main sources of the increase in negatively-valued deferred taxes cannot be readily identified but may be related to increases in restructuring and special charges and to a change in accounting treatment for employee benefits. ${ }^{31}$

\footnotetext{
${ }^{30}$ Deferred taxes can be negative for several reasons. For example, FRS companies typically pay income tax in excess of that provided by the regular corporate income tax. The excess is reported as current taxes and also results in a negative deferred tax since the excess is also a credit against future income tax payments. In 1992, the excess amounted to about $\$ 0.5$ billion and was equal to nearly 4 percent of current income taxes.

${ }^{31}$ Restructuring can result in reduced income tax obligations in future years. The expected future costs of implementing a company's restructuring plan (e.g., severance pay and early disbursements of pensions), which are recognized as special charges against this year's income, will reduce future taxable income and, consequently, future income taxes. Lower future income tax obligations are reflected as a decrease in deferred income taxes in this year's income statement.
} 
Table 14. Deferred, Current, and Total Income Tax Expense for FRS Companies, 1990-1992 (Million Dollars)

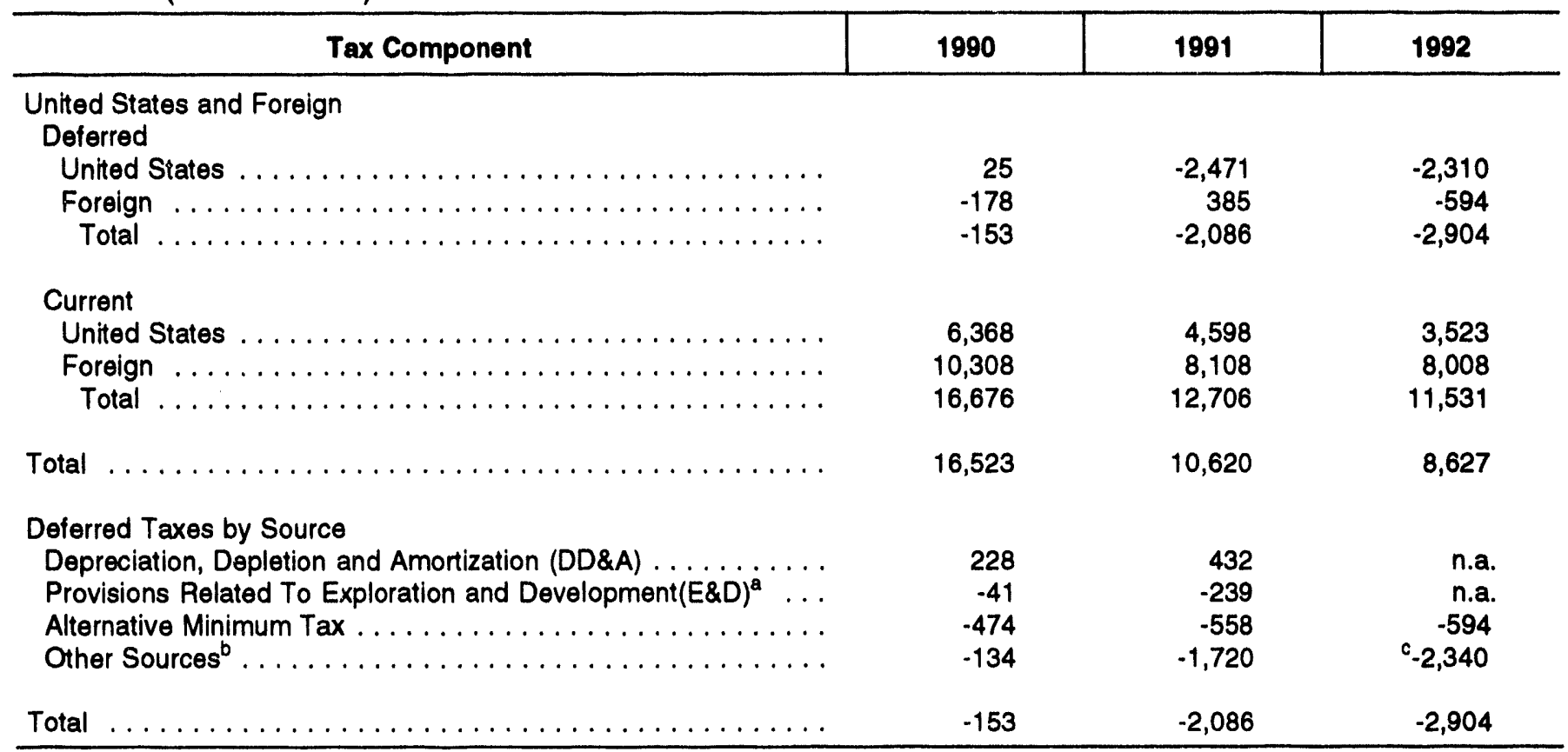

aprincipally intangible drilling costs.

DThe values for this category were adjusted so that the sum for all categories add to the totals shown. Data for the first two individual categories are estimated from company annual reports. The alternative minimum tax and totals are from the FRS system.

'Includes the aggregate value for those categories whose values are not available individually.

n.a. $=$ Not available.

Note: Sum of components may not equal total due to independent rounding.

Source: Company annual reports for the reporting year shown except for Total (including United States and Foreign), Alternative Minimum Tax, and Other Sources. Total and Alternative Minimum Tax are from Form ElA-28. Other Sources are calculated as the difference between the total and the sum of the first three deferred tax components shown.

The effective rate, calculated using current and deferred income taxes, for the U.S. FRS companies' petroleum line of business fell from about 34 percent in 1991 to about 31 percent in 1992 . The rate for foreign petroleum operations rose from 46 percent to about 49 percent (Table 15). These changes resulted from changes in the relative importance (as measured by pretax incomes) of the segments within each geographical area as well as from changes in the rates for the segments (Table 12). The fall in the effective rate for the domestic petroleum production segment, from 31.8 percent in 1991 to 27.4 percent in 1992, reflects the influence of tax offsets in keeping total taxes for that segment constant as pretax incomes rose.

\section{Non-Income Taxes}

The FRS companies pay many taxes in addition to income taxes. Although the dollar amount of U.S. non-income taxes has been constant for several years, their importance relative to total worldwide tax liabilities increased from 1990 to 1992, as income taxes declined. In 1990, U.S. non-income taxes were about 35 percent of total tax liabilities. In 1992, they accounted for nearly 51 percent as non-income taxes exceeded worldwide income taxes for the first time since at least 1980.

In 1992, the U.S. non-income tax liabilities of the FRS companies rose to $\$ 9.2$ billion from $\$ 9.0$ billion a year earlier (Table 16). Comprehensive data for these nonincome taxes are available only for those paid to U.S. government (Federal, State and local) authorities. The principal sources of the liabilities continued to be severance taxes; payroll taxes; and sales, use and property taxes. These three sources accounted for 78 percent of all U.S. non-income tax liabilities in 1992. The last of the three also accounted for essentially all of the increase in that year. 
Table 15. U.S., Foreign, and Worldwide Effective Income Tax Rates for FRS Companies, 1990-1992 (Percent)

\begin{tabular}{|c|c|c|c|}
\hline Area & 1990 & 1991 & 1892 \\
\hline 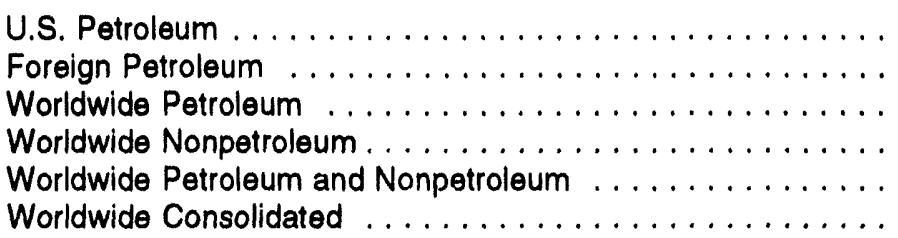 & $\begin{array}{l}34.2 \\
50.2 \\
42.4 \\
31.0 \\
40.8 \\
44.1\end{array}$ & $\begin{array}{l}34.2 \\
46.0 \\
41.3 \\
32.2 \\
40.3 \\
42.3\end{array}$ & $\begin{array}{l}31.3 \\
49.1 \\
41.1 \\
30.6 \\
39.5 \\
38.3\end{array}$ \\
\hline
\end{tabular}

Note: The effective rates, except for worldwide consolidated rates, are calculated on income tax expenses and pretax incomes allocated to individual lines of business. They do not include the taxes and pretax incomes that could not be allocated to those lines. Worldwide consolidated data are based on all income taxes and pretax incomes. All income tax expenses include both current and deferred taxes.

Source: Energy Information Administration, Form ElA-28.

Table 16. Additional U.S. Tax Liabilities of FRS Companies, 1990-1992 (Billion Dollars)

\begin{tabular}{|c|c|c|c|c|c|c|}
\hline \multirow[b]{2}{*}{ Tax Category } & \multicolumn{3}{|c|}{ Total } & \multicolumn{3}{|c|}{ Petroleum } \\
\hline & 1990 & 1991 & 1982 & 1990 & 1991 & 1992 \\
\hline Windfall Profits Tax . . . . . . . . . . & 0.0 & -0.1 & -0.1 & 0.0 & -0.1 & -0.1 \\
\hline Severance Tax ............. & 2.6 & 2.1 & 2.0 & 2.4 & 2.1 & 2.0 \\
\hline Supertund $\ldots \ldots \ldots \ldots \ldots$ & 0.3 & 0.3 & 0.3 & 0.3 & 0.3 & 0.3 \\
\hline Import Duties $\ldots \ldots \ldots \ldots \ldots$ & 0.1 & 0.1 & 0.1 & n.a. & n.a. & n.a. \\
\hline Sales and Use; Property . . . . . . . & 2.7 & 2.7 & 3.0 & n.a. & n.a. & n.a. \\
\hline Payroll $\ldots \ldots \ldots \ldots \ldots \ldots$ & 2.1 & 2.2 & 2.2 & n.a. & n.a. & n.a. \\
\hline Other $\ldots \ldots \ldots \ldots \ldots \ldots$ & 1.2 & 1.6 & 1.5 & n.a. & n.a. & n.a. \\
\hline Total $^{\mathrm{a}} \ldots \ldots \ldots \ldots \ldots$ & 9.1 & 9.0 & 9.2 & n.a. & n.a. & n.a. \\
\hline
\end{tabular}

aEcludes excise taxes collected on behalf of governments.

n.a. = Not available.

Note: Sum of components may not equal total due to independent rounding.

Source: Energy Information Administration, Form ElA-28. 


\section{Oil and Gas Exploration, Development, and Production in 1992}

\section{Income and Profitability}

Worldwide oil and gas production accounted for the major share of the FRS companies' net income in 1992 (Table 2, Chapter 2). Total net income from oil and gas production (excluding unusual items) was up 15 percent from 1991, mainly due to improved U.S. operations. Income from U.S. upstream operations increased due to higher production and prices of natural gas and lower oil and gas operating costs. This improvement was slightly offset by declining oil production and prices (Tables 17 and 18). Abroad, lower natural gas prices (Table 19) and lower crude oil prices tended to offset gains in production. However, lower tax expense in 1992, relative to 1991, enabled after-tax profits on foreign operations to rise (Table 17).

Lifting costs for FRS domestic oil and gas operations were reduced by $\$ 2.4$ billion in 1992 compared to 1991 (Table 17). This represents the latest step by FRS companies to reduce domestic costs of production, and to scale back their operations in the United States. Figure 12 traces trends in direct operating costs over the past decade. Per unit of production, U.S. lifting costs registered the steepest decline since 1986 (Figure 12), reaching an 11-year low. In 1992, direct lifting costs per barrel in the United States were actually lower than foreign lifting costs. In contrast, throughout the 1980's, U.S. costs were considerably higher than overseas lifting costs.

The downward trend in U.S. production costs by FRS companies reflects the effects of ongoing restructuring within the oil and gas sector. The key thrusts of the FRS companies' U.S. upstream strategies have been to scale back exploration activity-particularly in onshore locales in the lower- 48 states -and to consolidate producing operations, both to eliminate higher-cost fields and to realize overhead cost savings. For example, undeveloped U.S. unshore acreage held by the FRS companies totaled 44 million acres in 1992, down 18 percent from 1991, and less than a third of the acreage held in 1985, the year prior to the oil price
Figure 12. Direct Oil and Gas Production Costs for
FRS Companies, 1981-1992

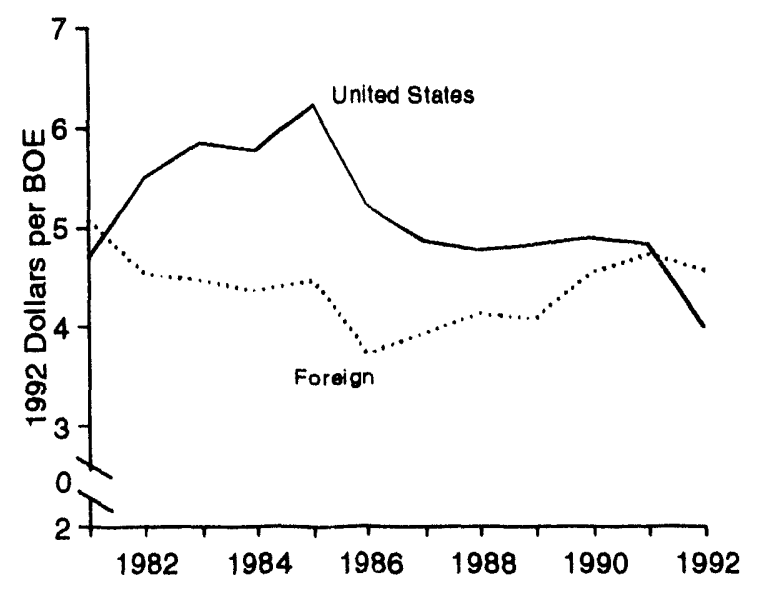

Source: Energy Information Administration, Form EIA-28.

collapse (Appendix B, Table B28). The number of U.S. onshore and offshore oil and gas producing wells of the FRS companies fell from 241,000 to 167,000 over the 1985 to 1992 period, with nearly all of the reduction occurring onshore.

The overall result of adjustments in U.S. upstream operations has been to narrow the gap in profitability between U.S. and foreign oil and gas production. Figure 13 shows that in 1992 the difference between U.S. and foreign upstream profitability was at a minimum for the 1986-1992 span. Significantly, as foreign rates of return have trended downward, returns on U.S. assets have risen. Over this period, the FRS companies' net investment base in U.S. oil and gas production declined from $\$ 119$ billion to $\$ 95$ billion while rising from $\$ 40$ billion to $\$ 57$ billion abroad (Appendix B, Table B11). The next section reviews aspects and patterns of the FRS companies' exploration and development investments and results in the area of oil and gas production. 
Table 17. Income Components and Financial Ratios in Oll and Gas Production for FRS Companies, 1991-1992

(Billion Dollars)

\begin{tabular}{|c|c|c|c|c|}
\hline \multirow[b]{2}{*}{ Components of Income and Financial Ratios } & \multicolumn{2}{|c|}{ United States } & \multicolumn{2}{|c|}{ Foreign } \\
\hline & 1991 & 1992 & 1991 & 1992 \\
\hline 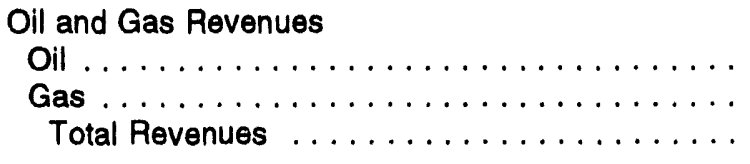 & $\begin{array}{l}32.4 \\
14.1 \\
46.4\end{array}$ & $\begin{array}{l}29.6 \\
16.9 \\
46.5\end{array}$ & $\begin{array}{l}\text { n.a. } \\
\text { n.a. } \\
34.9\end{array}$ & $\begin{array}{r}\text { n.a. } \\
\text { n.a. } \\
35.8\end{array}$ \\
\hline 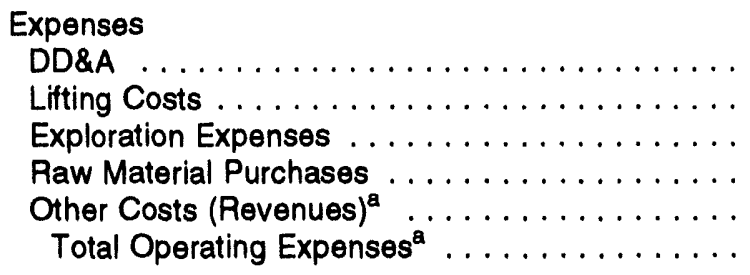 & $\begin{array}{r}12.5 \\
17.0 \\
2.5 \\
7.4 \\
-0.5 \\
38.9\end{array}$ & $\begin{array}{r}12.3 \\
14.6 \\
1.5 \\
7.0 \\
1.7 \\
37.1\end{array}$ & $\begin{array}{r}5.8 \\
11.1 \\
3.5 \\
\text { n.a. } \\
4.0 \\
24.4\end{array}$ & $\begin{array}{r}6.4 \\
11.3 \\
2.9 \\
\text { n.a. } \\
5.0 \\
25.6\end{array}$ \\
\hline Operating Income $e^{a}$ & 7.6 & 9.7 & 10.4 & 10.1 \\
\hline Other Income (Expense) $)^{a, b}$ & 0.3 & -0.6 & 0.6 & 0.8 \\
\hline Income Tax Expense $\ldots \ldots \ldots \ldots \ldots \ldots$ & 2.4 & 2.3 & 6.5 & 5.9 \\
\hline $\begin{array}{l}\text { Net Income, Excluding Unusual Items } \ldots \ldots \ldots \ldots \ldots \\
\text { Unusual Items } \ldots \ldots \ldots \ldots \ldots \ldots \ldots \ldots \ldots \ldots \ldots \ldots \ldots \ldots \ldots \ldots \\
\text { Net Incomem } \ldots \ldots \ldots \ldots \ldots \ldots \ldots \ldots \ldots \ldots\end{array}$ & $\begin{array}{r}5.5 \\
-0.5 \\
5.0\end{array}$ & $\begin{array}{r}6.4 \\
-0.8 \\
5.6\end{array}$ & $\begin{array}{l}4.5 \\
0.9 \\
5.4\end{array}$ & $\begin{array}{r}5.0 \\
-0.3 \\
4.7\end{array}$ \\
\hline $\begin{array}{c}\text { Unit Values (Dollars Per Barrel of Production COE) } \\
\text { Direct Lifting Costs (Excludes Taxes) } \ldots \ldots \ldots \ldots \\
\text { Production Taxes } \ldots \ldots \ldots \ldots \ldots \ldots \ldots \ldots \ldots\end{array}$ & $\begin{array}{l}4.72 \\
0.66\end{array}$ & $\begin{array}{l}3.99 \\
0.62\end{array}$ & $\begin{array}{l}4.61 \\
1.13\end{array}$ & $\begin{array}{l}4.57 \\
1.15\end{array}$ \\
\hline $\begin{array}{l}\text { Ratios (Percent) } \\
\text { Rate of Return } \\
\text { Effective Tax Rate }\end{array}$ & $\begin{array}{r}5.1 \\
31.8\end{array}$ & $\begin{array}{r}5.9 \\
28.4\end{array}$ & $\begin{array}{r}9.1 \\
54.9\end{array}$ & $\begin{array}{r}8.2 \\
54.2\end{array}$ \\
\hline
\end{tabular}

${ }^{a}$ Excludes unusual items.

${ }^{b}$ Earnings of unconsolidated affiliates, gain (loss) on disposition of assets, excluding unusual items not already excluded from operating income.

${ }^{\circ} \mathrm{COE}=$ Crude oil equivalent. Dry natural gass was converted at 0.178 barrels of oil per thousand cubic feet.

${ }^{d}$ Net income divided by net investment in place.

Income tax expense divided by pretax income.

n.a. $=$ Not available.

Note: Sum of components may not equal total due to independent rounding.

Source: Energy Information Administration, Form EIA-28. 
Table 18. Average Prices, Sales, and Production in Oll and Gas for FRS Companies, 1991-1992

\begin{tabular}{|c|c|c|c|}
\hline Prices, Sales, and Production & 1991 & 1992 & $\begin{array}{c}\text { Percent Change } \\
1991-1992\end{array}$ \\
\hline $\begin{array}{l}\text { Domestic Oil and Gas Production }{ }^{\mathrm{a}} \\
\text { Crude Oil and NGL (Million Barrels) } \ldots \ldots \ldots \ldots \ldots \ldots \ldots \\
\text { Dry Natural Gas (Billion Cubic Feet) } \ldots \ldots \ldots \ldots \ldots \ldots \\
\text { Total (Million Barrels, COE }{ }^{b} \text { ) } \ldots \ldots \ldots \ldots \ldots \ldots \ldots\end{array}$ & $\begin{array}{l}1,818.1 \\
7,509.5 \\
3,154.5\end{array}$ & $\begin{array}{l}1,750.2 \\
7,877.7 \\
3,152.4\end{array}$ & $\begin{array}{r}-3.7 \\
4.9 \\
-0.1\end{array}$ \\
\hline $\begin{array}{l}\text { Domestic Oil and Gas Sales Volumes } \\
\text { Crude Oil and NGL (Million Barrels) } \ldots \ldots \ldots \ldots \ldots \ldots \ldots \\
\text { Dry Natural Gas (Billion Cubic Feet) } \ldots \ldots \ldots \ldots \ldots \ldots \ldots \ldots \ldots \ldots \ldots \\
\text { Total (Million Barrels, COE }{ }^{b} \text { ) } \ldots \ldots \ldots \ldots \ldots \ldots \ldots\end{array}$ & $\begin{array}{l}2,077.8 \\
8,760.7 \\
3,637.2\end{array}$ & $\begin{array}{l}2,043.9 \\
9,712.4 \\
3,772.7\end{array}$ & $\begin{array}{r}-1.6 \\
10.9 \\
3.7\end{array}$ \\
\hline $\begin{array}{l}\text { Domestic Production Segment Per Unit Sales Values } \\
\text { Crude Oil and NGL (Dollars Per Barrel) . . . . . . . . . } \\
\text { Dry Natural Gas (Dollars Per Thousand Cubic Feet) . . . } \\
\text { Composite (Dollars Per Barrel COE }{ }^{b} \text { ) . . . . . . . . }\end{array}$ & $\begin{array}{r}15.58 \\
1.61 \\
12.77\end{array}$ & $\begin{array}{r}14.48 \\
1.74 \\
12.32\end{array}$ & $\begin{array}{r}-7.1 \\
8.4 \\
-3.5\end{array}$ \\
\hline $\begin{array}{l}\text { Foreign Oil and Gas Production }{ }^{a, c} \\
\text { Crude Oil and NGL (Million Barrels) } \ldots \ldots \ldots \ldots \ldots \ldots \ldots \\
\text { Dry Natural Gas (Billion Cubic Feet) } \ldots \ldots \ldots \ldots \ldots \ldots \ldots \ldots \ldots \ldots\end{array}$ & $\begin{array}{l}1,289.3 \\
3,658.8 \\
1,940.5\end{array}$ & $\begin{array}{l}1,292.4 \\
3,864.7 \\
1,980.3\end{array}$ & $\begin{array}{l}0.2 \\
5.6 \\
2.0\end{array}$ \\
\hline
\end{tabular}

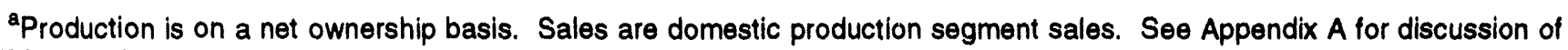
FRS reporting conventions.

${ }^{b} \mathrm{COE}=$ Crude oil equivalent. Dry natural gas was converted at 0.178 barrels of crude oil per thousand cubic feet.

'Sales value data are not available for foreign operations.

Source: Energy Information Administration, Form EIA-28.

Figure 13. Rates of Return in U.S. and Foreign Production for FRS Companies, 1977-1992

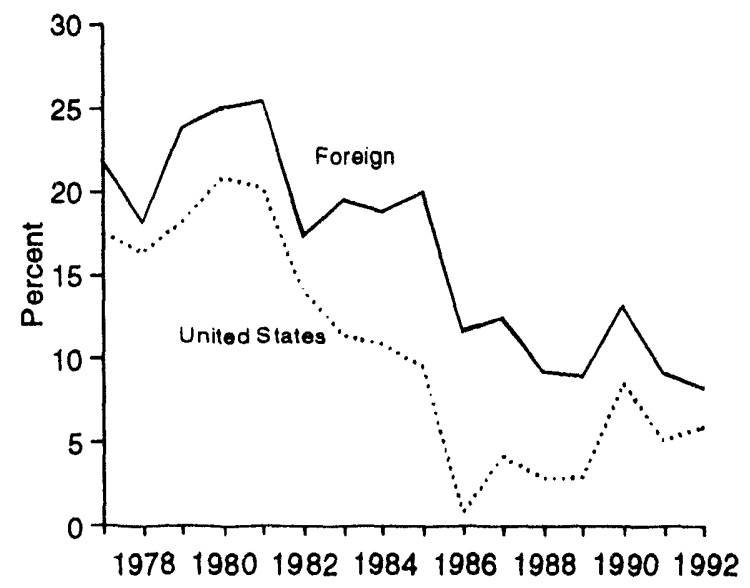

Source: Energy Information Administration, Form EIA-28.

\section{Exploration and Development Activity in 1992}

More than one half, or $\$ 24$ billion, of the FRS companies' 1992 cash flow was allocated to exploration and development. This was $\$ 4.7$ billion less than a year earlier (Table 20). Spending in the United States bore the brunt of this reduction, and for the first time FRS company spending abroad exceeded that allocated to U.S. operations (See the box below on foreign governments and overseas investment). In aggregate, U.S. spending was down 27 percent in 1992. The decline abroad was 6 percent; and most of that decline was in Canada, a producing area with cost-related characteristics similar to those in the United States. 


\section{Foreign Governments Attract Overseas Investment}

Global changes in industrial policy are providing additional stimulus to overseas investment by the FRS companies. To attract capital and technology, many countries are liberalizing their fiscal regimes. Some of the more common changes include:

- reduced income tax rates and royalty holidays;

- new deductions of financing costs from income taxes;

- reductions in the government's share for production-sharing contracts in new high-cost areas; and

- accelerated depreciation of some capital investments.

As an incentive for producers to develop marginal fields, the British Government has provided substantial tax breaks to North Sea oil and gas producers. The negotiation of more favorable terms on specific marginal fields is a device that is being adopted by other host governments. Both the company and the host government benefit from production and tax revenues from fields that would otherwise not be developed.

Latin America, for a long time closed to investments by FRS companies, is now offering acreage for exploration and development. Venezuela recently signed production-sharing agreements with Exxon, Royal Dutch/Shell, and Mitsubishi. These companies will enter into partnership with Petróleos de Venezuela S.A. to convert natural gas into liquefied natural gas for export to the United States. In Colombia, the giant Cuisiana field, with estimated reserves of 2 billion barrels, is being developed by a partnership of Ecopetrol (Colombia's state oil company), BP, Total, and Triton Energy, a U.S. independent."

Some of the republics of the former Soviet Union, particularly Russia, have extensive reserves, estimated at 57 billion barrels of oil and 1,750 trillion cubic feet of gas. ${ }^{b}$ Russia's Arctic Barents, and Kara and White Sea provinces have the potential to follow the North Sea as the world's next big offshore play. DuPont (Conoco) is an active partner in the development of the Ardalinsky, Dosynshevsky, and Kovinsky fields in the White Sea.

\footnotetext{
a"Latin America's Oil Rush: Tapping into Foreign Investors," New York Times, Sunday, July 11.

'Energy Information Administration, Annual Energy Review 1992, DOE/EIA-0384(92) (Washington, DC, June 1993), p. 271.
}

In 1992, more than one-half of all foreign exploration and development expenditures, or $\$ 7$ billion, was directed to Europe (mostly to the North Sea). This was slightly less than in 1991 (Table 20). European development spending increased from $\$ 4.6$ billion in 1991 to $\$ 5.2$ billion in 1992 , while spending on exploration declined.
Expenditure cutbacks were concentrated in acreage acquisition and basic exploration, reflecting a scaling back of exploratory activity in favor of development of current resource holdings (Table 21 and Figure 14). Abroad, development spending rose, while in the United States it fell 19 percent. 
Table 19. Forden Natural Gas Prloss for Leading Fa8 Natural Gas Producors, 1901-1902 (Dollars per Million Cublc Feet))

\begin{tabular}{c|c|c|c|c}
\hline & Total Forolgn & Canada & Europe & Othor Forolgn \\
\hline $1991 \ldots \ldots \ldots \ldots$ & 2.22 & 1.26 & 3.09 & 2.02 \\
$1992 \ldots \ldots \ldots \ldots$ & 2.07 & 1.10 & 2.84 & 1.03 \\
\hline
\end{tabular}

Sources: Computed from price and quantity data presented in Securities and Exchange Commission Form 10K, Annual Reporte to Shareholders, and Supplements to Annual Reports for Amoco, Chevron, Du Pont, Exxon, Mobll, Phillips, and Unocal. These seven companies are the loading producere of forelgn natural gas among the FAS companies and accounted for 80 percent of total FAS foreign natural gas production in 1992.

Table 20. Exploration and Devolopment 8ponding for FR8 Companies by Reglon, 1991-1992

\begin{tabular}{|c|c|c|c|}
\hline Region & 1091 & 1992 & $\begin{array}{c}\text { Percent Change } \\
\text { 1991-1992 }\end{array}$ \\
\hline & \multicolumn{2}{|c|}{ (million dollars) } & \\
\hline $\begin{array}{l}\text { Domestic } \\
\text { Onshore } \ldots \ldots \ldots \ldots \ldots \ldots \ldots \ldots \ldots \ldots \ldots \ldots \ldots \ldots \ldots \ldots \\
\text { Otfshore } \ldots \ldots \ldots \ldots \ldots \ldots \ldots \ldots \ldots \ldots \ldots \ldots \\
\text { Total United States } \ldots \ldots \ldots \ldots \ldots \ldots \ldots \ldots \ldots \ldots\end{array}$ & $\begin{array}{r}9,590 \\
4,615 \\
14,205\end{array}$ & $\begin{array}{r}7,296 \\
3,018 \\
10,314\end{array}$ & $\begin{array}{l}-23.9 \\
-34.6 \\
-27.4\end{array}$ \\
\hline 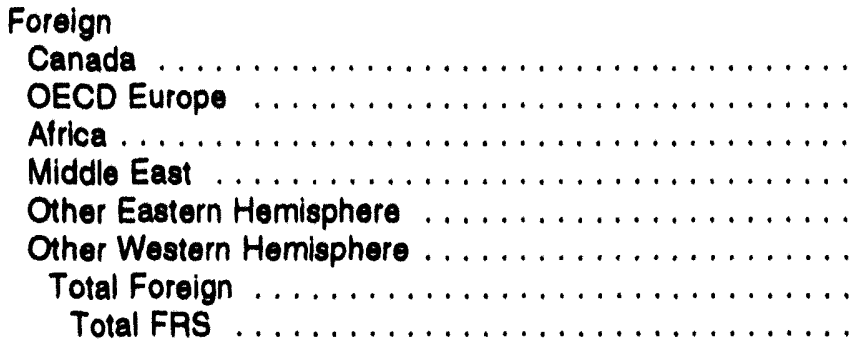 & $\begin{array}{r}1,731 \\
6,835 \\
1,525 \\
491 \\
2,387 \\
735 \\
13,704 \\
27,909\end{array}$ & $\begin{array}{r}1,106 \\
6,796 \\
1,393 \\
558 \\
2,409 \\
647 \\
12,909 \\
23,223\end{array}$ & $\begin{array}{r}-36.1 \\
-0.6 \\
-8.7 \\
13.6 \\
0.9 \\
-12.0 \\
-5.8 \\
-16.8\end{array}$ \\
\hline
\end{tabular}

Source: Energy Information Administration, Form EIA-28.

Flgure 14. FRS Companies' U.S. and Forelgn Exploration and Development Expenditures in 1992 Dollars, 1977-1992

a. Exploration

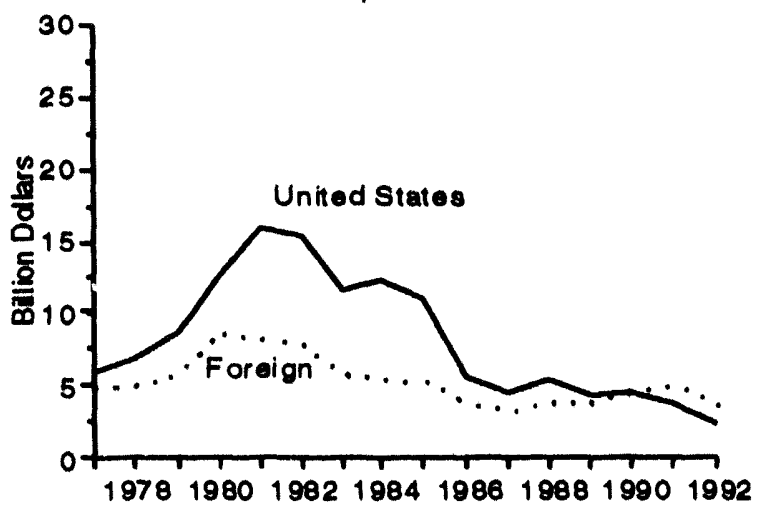

b. Development

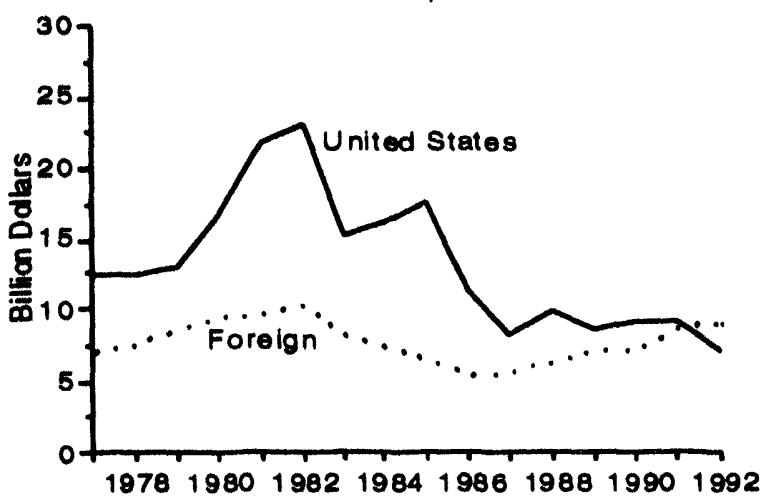

Note: Development expenditures exclude expenditures for proved acreage.

Source: Energy Information Administration, Form ElA-28. 
Table 21. Property Acquisition, Exploration, and Development Expenditures for FRS Companies, 1991-1992

\begin{tabular}{|c|c|c|c|}
\hline Items & 1991 & 1992 & $\begin{array}{c}\text { Percent Change } \\
1991-1992\end{array}$ \\
\hline & \multicolumn{2}{|c|}{ (million dollars) } & \\
\hline \multicolumn{4}{|l|}{ United States } \\
\hline Unproved Acreage & 568 & 257 & .54 .8 \\
\hline Proved Acreage .. & 1,137 & 541 & -52.4 \\
\hline$\ldots \ldots \ldots \ldots \ldots \ldots \ldots$ & 3,701 & 2,418 & -34.7 \\
\hline Development ${ }^{\mathrm{a}}$ & 8,799 & 7,098 & -19.3 \\
\hline Total . . . . . & 14,205 & 10,314 & -27.4 \\
\hline \multicolumn{4}{|l|}{ Foreign } \\
\hline Unproved Acreage & 349 & 175 & -49.9 \\
\hline Proved Acreage . . & 179 & 143 & -20.1 \\
\hline$\ldots \ldots \ldots \ldots \ldots \ldots \ldots$ & 4,905 & 3,868 & -21.1 \\
\hline$\ldots \ldots \ldots \ldots \ldots \ldots \ldots \ldots$ & 8,271 & 8,723 & 5.5 \\
\hline Total . . . . . & 13,704 & 12,909 & -5.8 \\
\hline \multicolumn{4}{|l|}{ World } \\
\hline Unproved Acreage & 917 & 432 & -52.9 \\
\hline$\ldots \ldots \ldots \ldots \ldots \ldots \ldots$ & 1,316 & 684 & -48.0 \\
\hline Exploration ........ & 8,606 & 6,286 & -27.0 \\
\hline Development ${ }^{\mathrm{a}}$. & 17,070 & 15,821 & -7.3 \\
\hline Total $\ldots \ldots \ldots \ldots \ldots \ldots \ldots \ldots \ldots \ldots \ldots$ & 27,909 & 23,223 & -16.8 \\
\hline
\end{tabular}

aDevelopment expenditures include support equipment.

Source: Energy Information Administration, Form ElA-28.

Recent cuts in overall exploration spending reflect current world oil price uncertainties. In 1992, aggregate world producing capacity was large relative to current demand, especially when potential supplies from Iraq are considered. In 1992, world oil prices declined 3 percent, ${ }^{32}$ and in real terms were nearly equal to their 1986 levels, after the oil price crash. ${ }^{33}$ In this context, companies shy away from aggressive exploration programs, which require long-term commitments and greater exposure to risk, favoring more secure development projects, which usually have quicker payouts.

Data on well completions, which distinguish exploratory wells from development wells, underscore the trend away from exploration, especially in the United States and Canada. Between 1990 and 1992, exploratory completions fell by half in these areas (Table 22). Outside the North American continent, exploratory completions declined by 14 percent.
Development well completions also declined in the United States and Canada between 1990 and 1992. However, in most other areas, where FRS companies are operating, the number changed little for development wells completed per year.

\section{Reserves and Production}

The shift in activity to overseas is not simply because of the higher foreign rates of return, but is also due to the need for FRS companies to find additional reserves to replace their own steadily depleting stock. Total U.S. oil reserves, as well as those of just the FRS companies, have been declining for both groups since the early 1970's. In mature domestic producing areas, reserve development to a large extent involves increasing recovery from known deposits of oil in place. As a result, in these areas most reserve additions are due to field "revisions" and to "improved recovery."

\footnotetext{
${ }^{32}$ Energy Information Administration, Monthly Energy Review, September 1993, p. 113.

${ }^{33}$ Energy Information Administration, Annual Energy Review, 1992, p. 71.
} 
Table 22. Well Ccmpletions by Region for FRS Companies, 1990-1992

\begin{tabular}{|c|c|c|c|c|c|c|}
\hline \multirow[b]{2}{*}{ Geographic Area } & \multicolumn{3}{|c|}{ Exploration Completions } & \multicolumn{3}{|c|}{ Developmeni Completions } \\
\hline & 1990 & 1891 & 1892 & 1990 & 1991 & 1992 \\
\hline \multicolumn{7}{|l|}{ United States } \\
\hline Onshore $\ldots \ldots \ldots \ldots \ldots \ldots \ldots$ & 1,033 & 735 & 533 & 5,277 & 4,418 & 3,439 \\
\hline Offshore $\ldots \ldots \ldots \ldots \ldots \ldots \ldots$ & 222 & 189 & 95 & 321 & 228 & 176 \\
\hline Total United States . . . . . . . . . . . & 1,254 & 924 & 627 & 5,598 & 4,646 & 3,615 \\
\hline \multicolumn{7}{|l|}{ Foreign } \\
\hline$\ldots \ldots \ldots \ldots \ldots \ldots$ & 215 & 194 & 114 & 370 & 299 & 280 \\
\hline Europe $\ldots \ldots \ldots \ldots \ldots \ldots \ldots$ & $10 \%$ & 101 & 75 & 81 & 84 & 67 \\
\hline Africa $\ldots \ldots \ldots \ldots \ldots \ldots \ldots$ & 40 & 44 & 48 & 32 & 57 & 53 \\
\hline Middle East $\ldots \ldots \ldots \ldots \ldots \ldots \ldots$ & 27 & 30 & 37 & 54 & 37 & 50 \\
\hline Other Eastern Hemisphere . . . . . . & 86 & 93 & 81 & 176 & 170 & 190 \\
\hline Other Western Hemisphere . . . . . . . & 23 & 26 & 12 & 90 & 93 & 89 \\
\hline Total Foreign $\ldots \ldots \ldots \ldots \ldots$ & 498 & 487 & 367 & 803 & 740 & 729 \\
\hline
\end{tabular}

Source: Energy Information Administration, Form EIA-28.

With lower prices, the level of U.S. oil reserves added through improved recovery by FRS companies in 1992 decreased by 44 percent, to 279 million barrels, while revisions declined by one-third (Table 23). The number of enhanced oil recovery projects in the United States, particularly those onshore, has been falling steadily not only because of low oil prices but also because of high production costs. With U.S. production outpacing reserve additions, the U.S. reserve-additions-toproduction ratio fell to 56 percent in 1992 (Table 23).

U.S. natural gas reserves for the FRS companies also declined in 1992, but the decline was small (less than 1 percent) despite relatively low levels of U.S. drilling activity. In general, prospects for gas are more favorable than for oil in the United States, as gas prices have begun to rise and as surplus natural gas supplies diminish. Also, Federal regulations which discouraged gas exploration and development have been replaced by regulations favoring gas use. Further, the Energy Policy Act of 1992 encourages the use of gas as a transportation fuel and favors the development of nonutility power plants, many of which are expected to burn natural gas.

In foreign areas, oil production rose in 1992, sustaining a slow but steady rate of increase evident since the late 1980's (Table 23). I 1992, reserve additions almost matched production so that net foreign oil reserves changed little. However, outside of Canada, most foreign areas have yielded reserve gains in excess of current production in recent years (Tables 23 and 24).

Foreign natural gas also promises to be a major factor in upstream expansion for FRS and non-FRS companies. In 1992, overseas natural gas production by FRS companies rose nearly 6 percent (Table 23). Though total foreign natural gas reserves changed little in 1992, they have increased more than 20 percent since 1986. Major gas reserve development efforts are now underway in the North Sea for distribution within Europe. In addition, liquified natural gas facilities are being expanded in Eastern Hemisphere areas to accommodate growing natural gas demand in Japan and otiner rapidly expanding economies in the Pacific Rim.

\section{Finding Rates and Finding Costs}

\section{Finding Rates}

The finding rate is typically defined as oil equivalent reserve additions per exploration and development well, including dry holes. The rate is usually expressed as a 3-year weighted average. This smooths out the volatility in discoveries and lessens the timing differences between the drilling of a well and the associated reserve additions. 
Table 23. Oll and Gas Reserves and Production for FRS Companies, 1991-1992

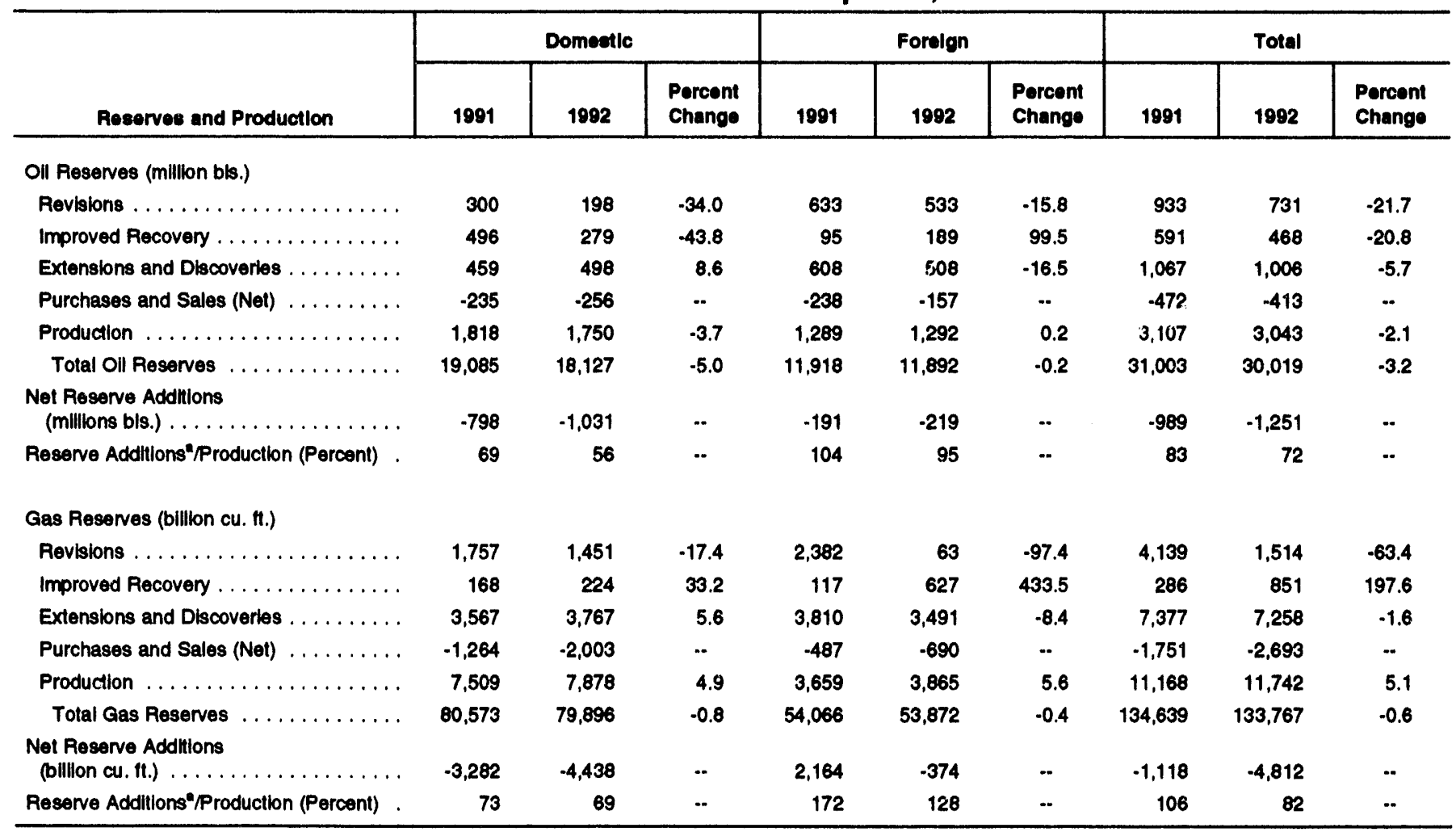

Excludes net purchases and sales.

-. = Not meaningful.

Note: Sum of components may not equal total due to independent rounding. Percent changes were calculated trom unrounded data.

Source: Energy Information Administration, Form EIA-28.

Table 24. Oll and Gas Reserve Additions by Reglon for FRS Companies, 1990-1992

\begin{tabular}{|c|c|c|c|c|}
\hline Geographic Area & 1990 & 1991 & 1992 & $\begin{array}{l}\text { Reserve Additions\% } \\
\text { Production Ratlo } \\
\text { (percent) }\end{array}$ \\
\hline & \multicolumn{3}{|c|}{ (millions of barrels of oil equivalent) } & \\
\hline \multicolumn{5}{|l|}{ United States } \\
\hline Onshore $\ldots \ldots \ldots \ldots \ldots$ & 2,307 & 1,676 & 1,408 & 74 \\
\hline Offshore $\ldots \ldots \ldots \ldots \ldots$ & 752 & 556 & 536 & 83 \\
\hline \multicolumn{5}{|l|}{ Foreign } \\
\hline Canada . . . . . . . . . . & 229 & 151 & 51 & 41 \\
\hline Europe $\ldots \ldots \ldots \ldots \ldots$ & 999 & 686 & 1,048 & 135 \\
\hline Africa $\ldots \ldots \ldots \ldots \ldots$ & 289 & 326 & 257 & 134 \\
\hline Middle East $\ldots \ldots \ldots \ldots \ldots$ & 37 & 73 & 151 & 86 \\
\hline Other Eastern Hemisphere ... & 552 & 947 & 451 & 143 \\
\hline Other Western Hemisphere . . & 156 & 276 & 16 & 101 \\
\hline Total Foreign $\ldots \ldots \ldots \ldots$ & 2,262 & 2,459 & 1,974 & 115 \\
\hline
\end{tabular}

aThree-year weighted average, 1990-1992.

Note: Additions include revisions, improved recovery, and extensions and discoveries. Sum of components may not equal total due to independent rounding. Percent changes were calculated from unrounded data.

Source: Energy Information Administration, Form EIA-28. 
There tends to be an inverse relationship between the profitability of oil and gas production and the finding rate. Higher prices enable producers to profitably drill smaller prospects. Lower prices render these prospects unprofitable, the result being increased emphasis on larger prospects. This increased emphasis on larger prospects is known as "prospect highgrading."

Prospect highgrading has contributed to increases in finding rates in recent years. Because of the decline in wellhead prices after 1986, an exploratory prospect that may have met a firm's criteria for drilling in 1985 was likely deemed uneconomical by 1992 . In the difficult economic environment of the 1990 's only the very best prospects, i.e., the largest in terms of expected recovery, were profitable to drill.

Reflecting the effect of prospect highgrading, the decline in activity by the FRS companies in the United States has been accompanied by a general improvement in the average finding rate. Onshore U.S. reserves added per well have increased from 233,000 barrels over the 1983 through 1985 period to 340,000 barrels in the 1990 through 1992 period. $^{34}$ Offshore, the improvement in the finding rate has been even more dramatic. In the period 1983 through 1985, the amount of reserves added per offshore well equaled 942,000 barrels of oil equivalent (BOE). In the period 1990 through 1992, the average FRS offshore exploration and development well added over 1.6 million BOE to reserves.

Some of the improvement in the finding rate is also attributable to improved technology. For instance, the application of 3-D seismic surveys has contributed to a dramatic increase in the offshore exploratory success rate. In 1992, the chances that an offshore exploratory well would be successful was almost 50 percent, as opposed to only 36 percent in $1985 .^{35}$ This increase in the success rate has contributed to an increase in the average reserves added per prospect drilled.

Finding rates for regions outside North America are generally higher than in the United States. These higher rates, however, do not come cheap. Those regions with higher discoveries per well are typically associated with higher exploration costs per well (Figure 15). Africa, with its lack of a developed infrastructure, appears to be a particularly expensive region to explore for oil and gas. The other expensive regions, in terms of per-well expenditures, include Europe and the Other Western Hemisphere. Nonetheless, exploratory activity in these high-cost areas appears to be justified by the greater prospects of making the large discoveries.

\section{Finding Costs}

Finding costs per barrel of oil equivalent are defined as the "cost" of exploration and development, excluding expenditures on proved reserves, divided by reserve additions excluding net reserve purchases. For the same reasons cited with finding rates, finding costs in this report are calculated as 3-year weighted averages.

Throughout much of the 1980 's, domestic finding costs substantially exceeded foreign finding costs. However, because of improved technology and prospect highgrading, the FRS companies have been successful in reducing the cost of finding oil and gas reserves in the United States (Figure 16). Average finding costs are now little different in the United States than overseas. This is somewhat remarkable given that, as recently as 1987, finding costs in the U.S. were 35 percent higher than overseas. As of 1992, FRS finding costs in the U.S. were actually lower than in Canada and Europe.

\footnotetext{
${ }^{34}$ Calculated as a 3-year weighted average of reserves added, excluding reserve purchases, per exploration and development well. Gas was converted to its oil equivalent using the conversion factor of 0.178 barrels of oil per thousand cubic feet of gas. Energy Information Administration, Form EIA-28.

${ }^{35}$ This increase is particularly striking given that the criteria for a well to be deemed commercial, i.e., successful (in terms of initial flows), is much more stringent today than in 1985. There tends to be an inverse relationship between the profitability of oil and gas production and the finding rate. Higher prices enable producers to profitably drill smaller pool prospects. Lower prices render these prospects unprofitable, the result being increased emphasis on larger pool prospects.
} 
Figure 15. Extensions and Discoveries per Exploratory Well and Costs per Woll

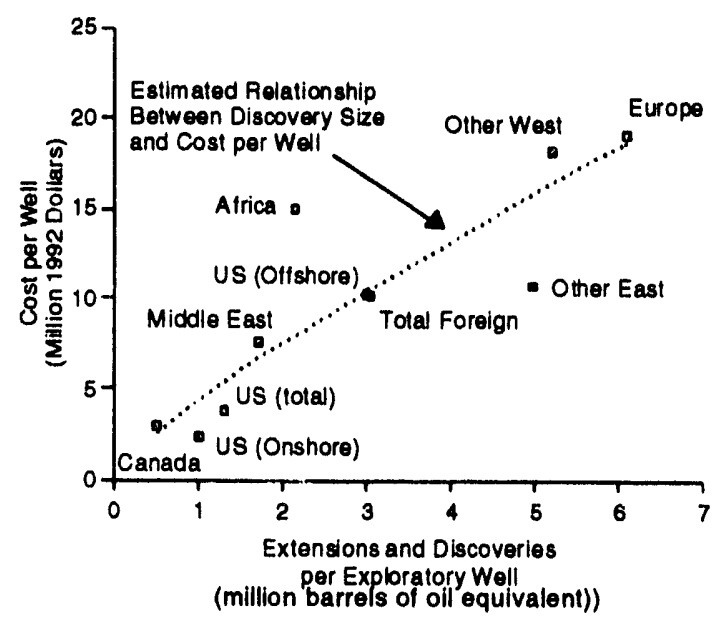

Note: Extensions and discoveries per exploratory well are calculated as a 3-year weighted average of extensions and discoveries on an oil equivalent basis. Gas was converted to its oil equivalent basis using a conversion factor of 0.178 barrels of crude oil per 1,000 cubic feet of gas. Cost per well was calculated as a 3-year weighted average of exploration expenditures (excluding unproved property costs) per exploratory well. All dollar conversions employed the GDP implicit price deflator. The fitted relationship in the figure is based on a regression analysis.

Source: Energy Information Administration, Form EIA-28.

Figure 16. Finding Costs in the United States and Outside North America

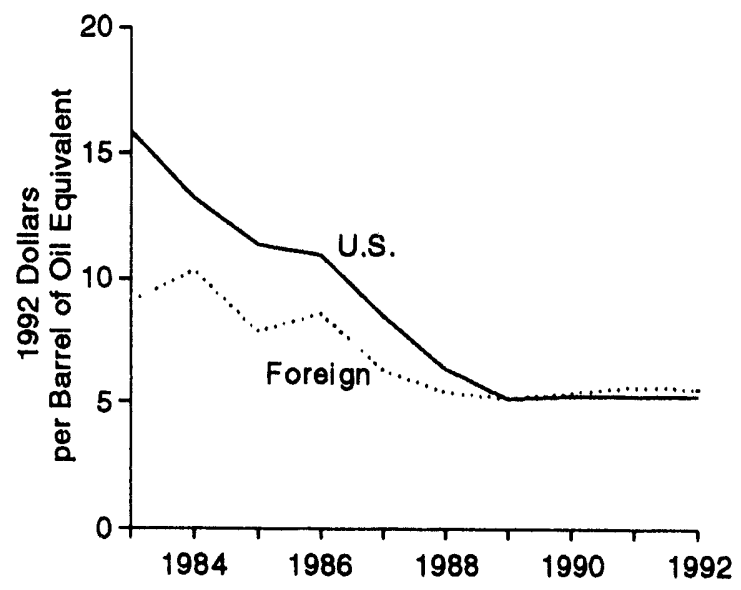

Source: Energy Information Administration, Form ElA-28.
The apparent convergence between foreign and domestic finding costs does not imply that the companies will increase, or at least not continue to reduce, the share of their expenditures allocated to the United States. The reason is that, in the absence of other considerations, exploration and development (E\&D) expenditures will be allocated on the basis of marginal finding costs, rather than average finding costs. While average finding costs in the United States are approximately equal to average foreign finding costs, U.S. marginal costs are apt to be far higher than those overseas since (1) marginal finding costs are inversely related to prospect size and (2) prospect size is far smaller in the United States than overseas. These points can be seen more clearly by examining the relationship between the average finding rate and average finding costs (Figure 17). If one considers Europe as an outlier, there is a clear negative relationship between average discovery size and the average cost per barrel of reserves added. Thus, while the search for "elephant fields" is expensive on a per-well basis, it is a strategy that has paid off for the FRS group of companies.

As the above discussion indicates, average U.S. and foreign finding costs for the FRS companies are roughly equal. This is not the case for 111 independents whose data were evaluated (Figure 18). The U.S. finding costs of these companies are substantially above their average foreign finding costs. In contrast to the FRS companies, who spend over half of their exploration and development budget overseas, these independents spent less than 20 percent of their budget outside the United States over the period 1990 through 1992. As a result of a relative underemphasis to date on foreign exploration and development, independents' overseas prospects tend to be far better at the margin (e.g., cheaper per barrel added to reserves) than they are in the United States. Prospectively, this differential suggests that the independents will continue to expand overseas exploration and development at the expense of their U.S. operations. Increased experience in foreign areas will further strengthen this trend.

\section{FRS Company Upstream Activity Highlights in 1992}

\section{The United States}

In 1992, major upstream petroleum activity in the United States was mainly limited to Alaska, some major 
Figure 17. Reserves Added per Well and the Finding Costs of the FRS Companies

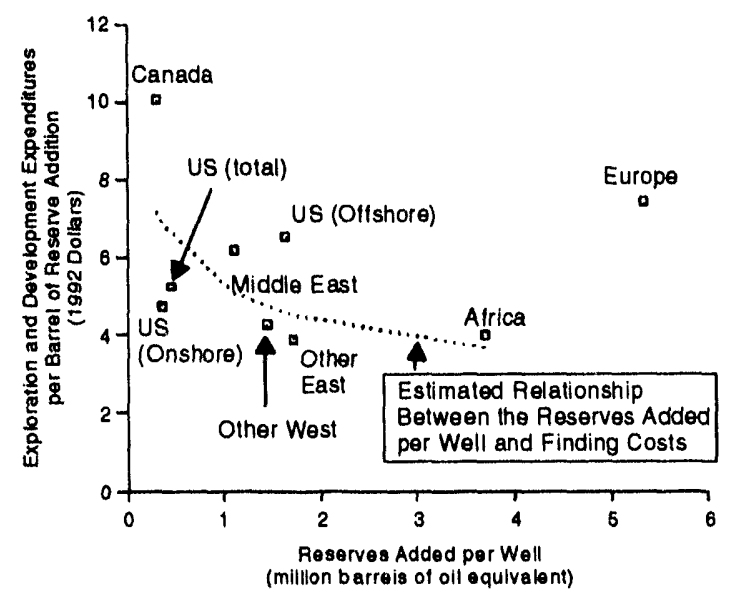

Note: Reserves added per exploration and development well are calculated as a 3-year weighted average of total reserve additions (excluding rescue purchases) divided by wells drilled. Exploration and development expenditures per barrel of reserve addition are measured as a 3-year weighted average of exploration and development expenditures (excluding expenditures on proved acreage) divided by barrels of reserve additions (excluding reserve purchases). Gas was converted to its oil equivalent using the conversion factor of 0.178 barrels of crude oil per 1,000 cubic feet of gas. All dollar conversions employed the GDP implicit price deflator. The estimated relationship between the reserves added per well and finding costs is based on a regression analysis. Because of the vastly different costs associated with offshore exploration and development, the U.S. offshore and Europe (North Sea) were excluded from the regression.

Source: Energy Information Administration, Form ElA-28.

plays in the deep waters of the Gulf of Mexico, and gas from unconventional sources. Oil production from the United States' largest oil field, Prudhoe Bay, has been declining since 1987. This has led to a decline in overall Alaskan oil production despite rising production from other fields such as Kuparuk River and Endicott. The decline was less than expected because BP America and its partners Exxon and ARCO undertook a project to slow the decline in production from Prudhoe Bay by reinjecting gas into the reservoir to maintain field pressure. The lives of the Alaskan Kuparuk River and Endicott fields are also expected to be extended using this type of recovery technique. The first phase of this \$1.9-billion Prudhoe Bay project was completed at a cost of $\$ 435$ million and is expected to recover an estimated 740 million additional barrels of oil. ${ }^{36}$
Figure 18. U.S. vs. Foreign Finding Costs for Independent Producers, 1988-1992

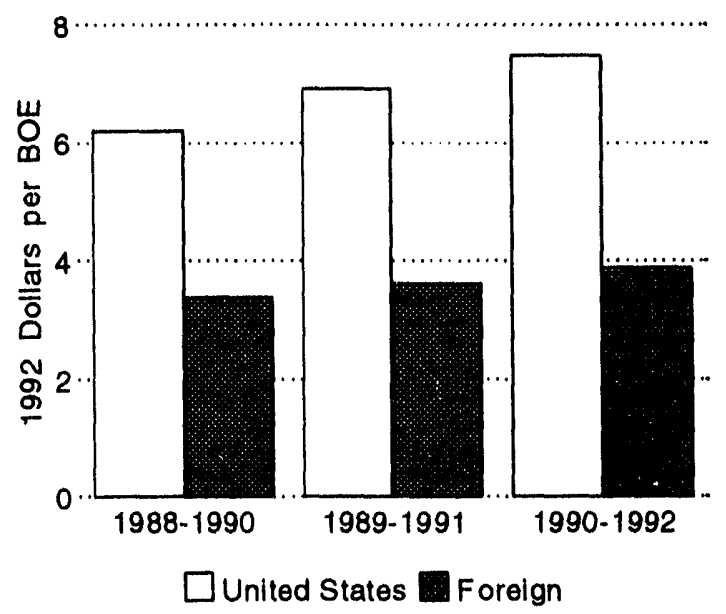

Note: Finding costs are measured as a 3-year weighted average of exploration and development expenditures, excluding expenditures on proved acreage, divided by oil equivalent reserve additions excluding reserve purchases. Gas was converted to its oil equivalent using the conversion factor 0.178 barrels of oil per thousand cubic feet of gas. Dollar values were converted to 1992 constant dollars using the implicit GDP deflator. The reported findings are based on a sample of 111 independents. Because of the large differential between finding costs in Canada and outside North America, the analysis excluded those independents whose primary foreign activities are in Canada.

Source: Arthur Andersen and Company reserve disclosure database.

New interest has been shown in Alaska's Cook Inlet, a region long written off for renewed major discoveries by most of the industry due to disappointing exploration results in the 1960 's. ARCO continued to believe in the potential for hydrocarbons in the Cook Inlet and its persistence paid off as a result of the discovery of the Sunfish field in December 1991. ARCO estimates that the Sunfish field could have substantial oil reserves..$^{37}$ The discovery of Sunfish is an example of the application of new technology to a region already extensively explored. ARCO reinterpreted their old data on the area and postulated a new geologic model of the oil trapping mechanism. ARCO made its discovery after the model had been tested and the prospect drilled. Since this initial discovery, ARCO has employed new 3-D seismic techniques to search the area north of Sunfish.

\footnotetext{
${ }^{36}$ Exxon, 1992 Annual Report, p. 11.

37"After Long Decline, Sunfish Strike Revives Interest in Cook Inlet," Offshore/Oilman Magazine, June 1993, p. 19.
} 
There were important developments in the Gulf of Mexico in 1992. Production facilities were improved in existing fields to boost production, while exploration of the deep waters of the Gulf continued. Shell concluded extensive redevelopment at South Timbalier 295 and in late 1992 production resumed at a rate of 10,000 barrels of oil per day. Previously, this field produced only 4,000 barrels per day. In the deep waters of the Gulf, Shell continued with the development of its Auger prospect, where production is expected to begin in early 1994. Shell's Bullwinkle project, located in 1,353 feet of water southwest of New Orleans, reached full capacity in 1992, with production averaging 45,000 barrels of crude oil and 62 million cubic feet of natural gas per day. ${ }^{38}$

In August 1992 Hurricane Andrew slammed into the Gulf of Mexico oil fields, damaging some production facilities. The Minerals Management Service estimated that 254 production platforms and satellite production facilities were damaged by the storm. Gas production from the Gulf was initially curtailed by 2.5 billion cubic feet per day due to storm damage, with full productive capacity not restored until December 1992. ${ }^{39}$

Onshore, much drilling was conducted for gas, particularly unconventional gas from tight sands and coalbed methane. Although drilling for coalbed methane reached record highs in 1991 and 1992, production was constrained by a lack of lease facilities. Phillips completed a gas gathering system in late 1992 for their coal-seam wells in the San Juan basin in New Mexico where its production averaged 185 million cubic feet per day. ${ }^{40}$

\section{North Sea - Emphasis on New Technology, Field Development, and Gas}

The North Sea has been an oil-producing center for many of the FRS companies since the late 1970's. However, production from most of the originallydiscovered fields is now in decline, and requires an expanded use of improved recovery techniques to maintain past levels. Additionally, smaller and less economic finds are becoming the rule. This is particularly the case in the U.K. sector where considerable effort is being expended on enhanced recovery and on the development of new technologies that allow for the development of smaller fields at relatively low cost.

The FRS companies have an array of North Sea projects that came on strearn in 1992 which should compensate for declining production from older fields. Some of the new production is coming from new fields, while the rest is due to the implementation of improved production technologies, such as fluid injection, applied to old fields. Horizontal drilling techniques are also being used to boost production.

One new technique for developing smaller fields uses North Sea production facilities already in place. Existing production platforms have been refurbished to produce from "satellite" wells which are drilled and completed many miles away. Using underwater completion techniques, wells can now be completed and linked to a remote production platform via a subsea production manifold and underwater pipe. Oil and gas are piped from the subsea completion area to the production platform, from where they are transported to shore using existing pipelines. The adoption of subsea completion techniques could eventually do away with the need to transport expensive production platforms to new fields. There are examples of hydrocarbons being piped as far as 60 miles from a subsea template to a production platform. Using the existing production facilities can cut development costs tremendously and allows for the development of fields that would otherwise be uneconomic.

The Scott field (operated by Amerada Hess) in the U.K. sector of the North Sea neared completion in 1992. Production from this field is expected to peak at 180,000 barrels of oil per day and 95 million cubic feet of natural gas per day. The development of the Scott field illustrates the new technologies that are now becoming commonplace in the North Sea. They include satellite production platforms, subsea production manifolds, and improved recovery through injection. ${ }^{41}$

Two of Europe's largest fields, the giant Statfjord and Oseberg fields in the Norwegian sector of the North Sea, provided the staging post for the development of a number of other satellite fields. The infrastructure currently existing in these fields allowed Mobil to begin the development of the Statfjord North, Statfjord East, and Oseberg East fields in a cost-effective way.

\footnotetext{
${ }^{38}$ Shell, 1992 Annual Report, p. 8.

${ }^{39}$ Natural Gas Issues and Trends, 1992, Energy Information Administration, DOE/EIA-0560(92), Washington DC, p. 7.

10Phillips, 1992 Annual Report, p. 11.

"Amerada Hess, 1992 Annual Report, p. 13.
} 


\section{Exploration Dominates in Africa}

To attract Western capital, many countries on the African West Coast are offering prime acreage for exploration under newly improved terms. Risk, whether geological or political, can be particularly high in some African countries. For instance, the Angolan civil war postponed further development of that countries' fields for many years. When the war abated during 1992, Chevron was one of the first FRS companies to become active in offshore Angola with five fields under development. ${ }^{42}$

Nigeria is the most prolific producing country in western Africa, accounting for production of almost 2 million barrels per day. Mobil and Chevron are very active in Nigeria, with Mobil laying claim to over 680 million barrels of reserves in the offshore Edop field. Mobil is also in the first phase of the development of the offshore Oso field with an estimated 500 million barrels of recoverable oil reserves. ${ }^{43}$ Amoco and Shell are currently exploring offshore Gabon, while Namibia has become a potentially attractive area, offering negotiable royalties rather than production-sharing agreements as an exploration inducement.

\section{Republics of the Former Soviet Union}

Although the FRS companies have not yet begun to report production statistics, or even exploration and development statistics, from the republics of the former Soviet Union, those republics have the potential to become a major source of production and income for the FRS companies in the near future. Amoco is active in negotiating the development of the Azeri field in the Azerbaijan sector of the Caspian Sea. The oil reserves potential of this field is estimated to exceed 1.5 billion barrels. A production-sharing agreement has been negotiated by BP for the Capaz field, also in the Caspian Sea, near the Turkmenistan frontier. Chevron has entered a production-sharing agreement with the government of Kazakhstan for production from the giant Tengiz gas field. Gas from this field is expected to supply the growing gas needs of Western Europe as well as more local markets.

Exploration and development in the republics of the former Soviet Union is fraught with risk-geological, economic, and political. In some cases, the extraction of more oil and gas will require an extensive overhaul of entire fields and the implementation of expensive enhanced recovery techniques. On the economic front, the disintegration of the Soviet Union and the industrial dislocation this has caused has led to shortages in oilfield equipment supplies. Furthermore, politically, the republics have yet to resolve disputes over resource ownership and other legal questions.

\section{Other Foreign Actlvity}

For the past few years, the FRS companies have been reentering the Middle Eastern arena, even though many of their assets were nationalized during the 1970's. Some FRS companies are selectively exploring in countries such as Yemen. Activity in Yemen accelerated in the early 1980's when a medium-sized independent oil company, Hunt Oil, discovered considerable oil reserves there. In Yemen, Shell Oil and partners drilled 18 exploratory wells in 1992 and made four discoveries. Also, Shell drilled seven production wells in five fields. Amoco was active in Sharjah in 1992, adding natural gas and liquids reserves, while Texaco resumed production from Neutral Zone fields damaged after the Gulf War. ${ }^{44}$

BP, Total, and an independent producer, Triton Energy, have been actively developing the giant Cuisiana field in Colombia, South America (originally discovered by another FRS company, Occidental). This is a prime example of the new receptiveness of foreign countries to the FRS companies and other international oil companies. In the negotiated production-sharing agreement, half the production from this field will go to Columbia's state oil company, Ecopetrol, with the remaining production shared among the major partners. Recoverable reserves in Cuisiana and a nearby field, Cupiagua, are estimated to be at least 2 billion barrels. ${ }^{45}$ The economics of the field's development are enhanced through the use of low-cost production modules that can be built and located within a year.

Other areas of South America which saw activity by the FRS companies in 1992 include Argentina, Bolivia, Guyana, Peru, and Venezuela. However, many of the projects underway in these countries are only in the preliminary exploration phase; for example, Mobil acquired 550 line-kilometers of seismic data in Argentina in 1992.

\footnotetext{
${ }^{42}$ Chevron, 1992 Annual Report, p. 10.

"3"Operators, Service Contractors Settle Down to New World Balance," Offshore Magazine, May 1992, p. 54.

"The Neutral Zone lies between Kuwait and Saudi Arabia.

45„Latin America's Oil Rush: Tapping into Foreign Investors," New York Times, July 11, 1993, p. 5.
} 
The FRS companies are continuing to expand their roles in Indonesia, entering into many joint projects with Pertamina, the state-owned petroleum company. Australia, which has always been receptive to foreign investment, has seen activity expand on its northwest offshore shelf. Chevron and partners are currently developing gas fields and nearby oil fields on the northwest shelf. It is expected that as with Indonesia, Australia will find ready markets in the expanding Far Eastern trade in liquefied natural gas.

Unocal was very active in the Gulf of Thailand in 1992, with production of 709 million cubic feet of gas per day. ${ }^{46}$ Seeking to supply a growing Thai market for natural gas, Unocal brought several fields on stream during 1992. Unocal is also active in Indonesia, producing gas for liquefaction and export.

${ }^{46}$ Unocal, 1992 Annual Report. 


\section{Downstream Petroleum in 1992}

In 1992, net investment in place in refining, marketing, and transportation for the FRS companies amounted to $\$ 104$ billion, which was 31 percent of total net investment in place of $\$ 332$ billion (Appendix $B$, Table B11). About two-thirds of these assets were in the United States. In the 1970's and early 1980's, refining and marketing operations worldwide yielded low profits, as high prices constrained demand for refined products. As a result, refining and marketing operations were subject to significant disinvestment, particularly outside the United States. Subsequent to the oil price collapse of 1986, growth in petroleum product demand began to recover and the profit outlook for crude oil processing improved. As a result, investment commitments to refining and marketing operations have risen both absolutely and in relative terms. These investments have generally yielded rates of return comparable to those earned from upstream petroleum operations. Profits in domestic refining and marketing in 1992, however, were poor.

\section{Income and Profitability}

\section{Domestic Refining and Marketing Profits in 1992}

For the first time since EIA began collecting line of business profit data in 1977, the FRS companies reported a net loss for the U.S. refining and marketing segment. FRS companies' return on investment in this U.S. downstream segment in 1992 was a negative 0.4 percent (Figure 19).

The loss would have been even greater had the FRS companies not benefitted from a fairly buoyant U.S. refinery product market in 1992. Total U.S. petroleum consumption grew 2 percent between 1991 and 1992. Motor gasoline consumption drove the rebound in refined product demand as higher personal income boosted motor vehicle travel. Partly due to increased transportation demand, distillate consumption also rose in 1992. Higher levels of industrial output along with relatively cooler temperatures, following an unusually

\author{
Figure 19. Refining and Marketing Return on \\ Investment for the FRS Companies, \\ 1981-1992
}

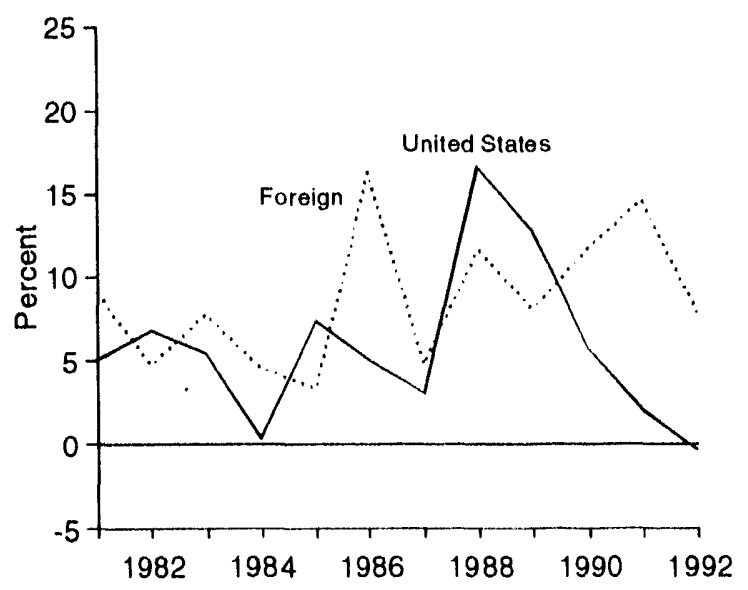

Note: Net income as a percent of net investment in place. Source: Energy Information Administration, Form EIA-28.

warm winter, also helped to lift the demand for diesel fuel and home heating distillates. ${ }^{47}$

U.S. refined product sales revenue for FRS companies was down 3 percent in 1992 (Table 25). Although sales volume was higher, the average product price fell by nearly a dollar a barrel, outpacing the decline in raw material costs of $\$ 0.75$ per barrel (Table 25 ) and causing a 3-percent decline in gross margins (Table 26). The value of refined product sales was also reduced by the departure of Total Petroleum (North America) from the roster of FRS companies. Absent Total in both 1991 and 1992, the FRS companies reported a 3-percent rise in company motor gasoline and distillate fuel sales. This improvement in product demand, however, was concentrated in the fourth quarter of 1992, and was insufficient to prevent refined product prices from falling by more than crude oil input costs for the year as a whole. As a consequence, the improvement in FRS refined product sales volumes was not matched by U.S. downstream revenue gains, income performance, or profitability.

\footnotetext{
${ }^{47}$ Energy Information Administration, Monthly Energy Review, September 1993, DOE/EIA-0035(93/09), ( Washington, DC, September 1993) pp. 48-68.
} 
Table 25. Sales, Expenses, and Income in U.S. Refining/Marketing for FRS Companies, 1991-1992

\begin{tabular}{|c|c|c|c|}
\hline Sales, Expenses, and Income & 1991 & 1992 & $\begin{array}{c}\text { Percent Change } \\
1991-1992\end{array}$ \\
\hline & \multicolumn{2}{|c|}{ (billion dollars) } & \\
\hline Refined Product Sales $\ldots \ldots \ldots \ldots \ldots \ldots \ldots \ldots \ldots \ldots$ & 128.0 & 124.1 & -3.0 \\
\hline Other Revenues $\ldots \ldots \ldots \ldots \ldots \ldots \ldots \ldots \ldots \ldots$ & 80.4 & 83.0 & 3.2 \\
\hline Total $\ldots \ldots \ldots \ldots$ & 208.5 & 207.2 & -0.6 \\
\hline Operating Income $\ldots \ldots$ & 1.4 & 0.1 & -90.7 \\
\hline \multirow[t]{2}{*}{ Contribution to Net Income } & 0.9 & -0.2 & -- \\
\hline & \multicolumn{2}{|c|}{ (million barrels per day) } & \\
\hline \multirow[t]{2}{*}{ Refined Product Sales } & 13.0 & 13.1 & 0.5 \\
\hline & \multicolumn{2}{|c|}{ (dollars per barrel sold) } & \\
\hline \multicolumn{4}{|l|}{ Average Sales Price } \\
\hline Gasoline ....... & 30.43 & 29.61 & -2.7 \\
\hline Distillate . . . . . . . . & 26.39 & 24.87 & -5.7 \\
\hline Other $\ldots \ldots \ldots \ldots \ldots \ldots \ldots \ldots \ldots \ldots$ & 20.64 & 19.98 & -3.2 \\
\hline All Refined Products & 26.94 & 25.98 & -3.6 \\
\hline $\begin{array}{l}\text { Raw Material Input and Product Purchases per Barrel .... } \\
\text { Average Sales Price Less Cost of Raw Materials }\end{array}$ & 19.86 & 19.11 & -3.8 \\
\hline and Product Purchases $\ldots \ldots \ldots \ldots \ldots \ldots \ldots \ldots$ & 7.08 & 6.87 & -3.0 \\
\hline Refined Product Margin & 0.74 & 0.38 & -48.6 \\
\hline
\end{tabular}

a See Appendix $\mathrm{b}$, Table B48 for the r.umponents to calculate the refined product margin.

$-=$ Not meaningful.

Note: Sum of compe ents may not equal total due to independent rounding. Percent changes were calculated from unrounded data.

Source: Energy Inform ation Administration, Form EIA-28.

Table 26. Component: of Refined Product Margin for FRS Companies, 1989-1992

\begin{tabular}{|c|c|c|c|c|c|c|}
\hline Componeitt & 1989 & 1990 & 1991 & 1992 & $\begin{array}{c}\text { Change } \\
\text { 1989-1992 }\end{array}$ & $\begin{array}{c}\text { Percent Change } \\
1989-1992\end{array}$ \\
\hline & \multicolumn{4}{|c|}{ (dollars per barrel) } & & \\
\hline Gross Margin ${ }^{a}$ & 6.61 & 7.17 & 7.08 & 6.87 & 0.26 & 3.9 \\
\hline Marketing Cost .... & 1.82 & 2.04 & 2.41 & 2.70 & 0.88 & 48.4 \\
\hline Other Refining Cost ${ }^{b}$ & 1.59 & 1.87 & 1.91 & 1.89 & 0.31 & 19.5 \\
\hline Energy Cost $\ldots \ldots \ldots \ldots$ & 1.06 & 1.13 & 1.17 & 1.12 & 0.06 & 5.7 \\
\hline Other Product Supply Cost & 0.67 & 0.95 & 0.80 & 0.78 & 0.11 & 16.4 \\
\hline Refined Product Margin . & 1.47 & 1.18 & 0.73 & 0.38 & -1.09 & -74.1 \\
\hline
\end{tabular}

${ }^{a}$ Refined product revenues less raw material input cost and refined product purchases.

${ }^{b}$ Excluding management fees.

Source: Energy Information Administration, Form EIA-28.

Refining and marketing costs per barrel of petroleum product rose in 1992, continuing a trend evident for over the past 5 years. Marketing costs (which include the costs of blending gasoline components such as MTBE, advertising costs, and credit card processing expenses) in 1992 were nearly 50 percent higher than in 1989, while other refining expenses also increased significantly over that time period, but fell slightly from the 1991 level (Table 26). The trend toward producing lighter products and using greater downstream processing capacity has increased operating costs. Environmental requirements for refinery emissions reduction, reformulated gasoline, and Reid Vapor Pressure standards have also added to operating costs. In 1992, new environmental requirements mandated under the Clean Air Act Amendments (CAAA) of 1990 took effect, involving the marketing of oxygenated gasoline in urban areas with poor air quality. Title II of 
the CAAA, enacted on November 15, 1990, sets forth several provisions related to mobile sources of air pollution:

Provision

Effective Date

Oxygenated gasoline . . . . . . . . . . November 1, 1992

Low-sulfur, on-highway diesel fuel . . October 1, 1993

Reformulated gasoline, phase 1 . . . J January 1, 1995

Leaded gasoline ban . . . . . . . . . J January 1, 1996

Clean-fueled fleet vehicles . . . . . . . . January 1, 1998

Reformulated gasoline, phase $2 \ldots$ January 1, 2000

On the basis of the CAAA, the Environmental Protection Agency (EPA) designated 39 areas of the country as mobile source carbon monoxide (CO) nonattainment areas. Beginning no later than November 1, 1992, all motor gasoline sold in the CO nonattainment areas (about 31 percent of total gasoline sales) during winter months (the "CO season") must contain no less than 2.7 percent oxygen by weight in the form of blended oxygenates. ${ }^{48}$ The $\mathrm{CO}$ season lasts a minimum of 4 months.

\section{The 1992-1993 Oxygenated Gasoline Season}

A serious concern prior to implementation of the oxygenate program was whether the U.S. refining industry would be able to recover the added costs to refiners. Refiners faced a number of potential problems: (1) a potential shortfall in the supply of methyl tertiary butyl ether (MTBE), (2) a potential oversupply of gasoline created by the blending of a large volume of oxygenates, and (3) logistical constraints in their abilities to market oxygenated gasoline only in nonattainment areas. The oversupply of gasoline and the sale of high-cost oxygenated gasoline outside of nonattainment areas, where it would not be able to command an appropriate price premium, could squeeze both refining margins and profits.
However, an oversupply of MTBE became evident even before the 1992-1993 oxygenated gasoline season ended, contributing to a collapse in MTBE spot market prices from 98 cents per gallon in June 1992 to 71 cents per gallon in January $1993 .^{49}$ Refiners who were committed to contract purchases of MTBE at over $\$ 1.00$ per gallon faced competition from blenders who could take advantage of the low-priced MTBE on the spot market. The impact of the oversupply of MTBE on the competitive performance of a company's refining operations depended, in part, on whether the MTBE was manufactured in-house, bought at contract prices, or purchased on the spot market.

Although FRS companies market in both attainment and nonattainment areas, some FRS companies are more heavily committed to nonattainment areas. FRS companies followed divergent paths to adapt to the demands of manufacturing oxygenated gasoline. Some FRS companies have decided to produce their own oxygenates, while other FRS companies chose to purchase these additives. These decisions were influenced in part by the geographic marketing area served by a particular company. For example, an appropriate refining strategy for a company marketing its gasoline exclusively in nonattainment areas might be inappropriate for a company marketing its gasoline strictly in attainment areas. Phillips Petroleum, for instance, which markets half of its gasoline in attainment areas, announced that it would buy oxygenates rather than manufacture them. ${ }^{50}$

A number of companies considered joint ventures as a means of obtaining an adequate supply of oxygenates. Chevron, for instance, which owns three MTBE units, contracted with ARCO to supply Chevron with ethyl tertiary butyl ether (ETBE). ${ }^{51}$ Mobil and BP jointly developed a new process for the production of MTBEs, ${ }^{52}$ while ARCO Chemical and Coastal reached an agreement in principle to produce ETBEs at Coastal's Corpus Christi MTBE facility. ${ }^{53}$

\footnotetext{
${ }^{48}$ Oxygenates are liquid organic compounds which contain oxygen, and are approved by the EPA as substantially similar to motor gasoline. Blended oxygenates significantly lower the level of carbon monoxide produced during gasoline combustion. Several alcohols and ethers can be used as oxygenates, but only two are used in significant quantities. These are methyl tertiary butyl ether (MTBE) and fuel ethanol.

${ }^{19}$ Platt's Oilgram Price Report, p. 1.

50Phillips Petroleum Company, Annual Report 1992, p. 17.

${ }^{51}$ Alcohols Week's New Fuels Report, Vol. 13 No. 39, September 28, 1992, p. 2. ETBE is an oxygenate blend stock formed by the catalytic etherification of isobutylene with ethanol. ARCO's plant in Corpus Christi, Texas is capable of producing either MTBE or ETBE. Refiners hesitate to use ETBE because ethanol is in direct competition with MTBE, a refinery byproduct. However, ETBE production may increase because of its lower reid vapor pressure characteristics, and concern over potential methanol supply problems in the future.

${ }^{52}$ Alcohol Week's New Fuels Report, Vol. 13 No. 27, July 6, 1992, p. 4.

${ }^{53}$ Oxy-Fuel News, September 7, 1992, p. 1.
} 


\section{Foreign Refining and Marketing Profltabllity}

Foreign downstream earnings declined 46 percent relative to 1991 (Table 27). Nevertheless, foreign refining operations were more profitable than domestic operations in 1992. The FRS companies' foreign earnings were $\$ 2.2$ billion and the return on investment was 7.8 percent (Table 27 and Figure 19).

Recession throughout most of Europe in $1992 \mathrm{kept}$ demand for refined products at the low levels of 1991.
Also, a mild winter reduced petroleum product demand in Western Europe in the fourth quarter of 1992 over 2 percent below $1991 . .^{54}$ Several FRS companies rely on sales to Europe for a major part of their foreign refining and marketing earnings. Exxon, alone, has 11 percent of the European Community refined product market. Exxon sells 40 percent of its worldwide refined products there, compared with 35 percent in North America. ${ }^{55}$ Mobil sells almost 30 percent of its refined products in Europe. ${ }^{56}$ European product sales volumes increased from 1991 for several

Table 27. Refining and Marketing Financial ltems and Operating Data for FRS Companles, 1981-1992

\begin{tabular}{|c|c|c|c|}
\hline Financial Items & 1991 & 1892 & $\begin{array}{c}\text { Percent Change } \\
1991-1992\end{array}$ \\
\hline & \multicolumn{2}{|c|}{ (billion dollars) } & \\
\hline United States $\ldots \ldots \ldots \ldots \ldots \ldots \ldots \ldots \ldots \ldots$ & 0.9 & -0.2 & $\cdots$ \\
\hline Foreign $\ldots \ldots \ldots \ldots \ldots \ldots \ldots \ldots \ldots \ldots$ & 4.2 & 2.2 & -45.7 \\
\hline Total $\ldots \ldots \ldots \ldots \ldots \ldots \ldots \ldots \ldots$ & 5.0 & 2.0 & -59.7 \\
\hline \multicolumn{4}{|l|}{$\begin{array}{l}\text { Additions to Investment in Place } \\
\text { United States }\end{array}$} \\
\hline Refining $\ldots \ldots \ldots \ldots \ldots \ldots \ldots \ldots \ldots$ & 4.8 & 5.2 & 8.3 \\
\hline Marketing $^{a} \ldots \ldots \ldots \ldots \ldots \ldots \ldots \ldots \ldots \ldots$ & 3.1 & 2.3 & -26.7 \\
\hline Total $\ldots \ldots \ldots \ldots \ldots \ldots \ldots \ldots$ & 7.9 & 7.4 & $\cdot \quad-5.5$ \\
\hline Foreign Refining and Marketing $\ldots \ldots \ldots \ldots \ldots$ & 3.9 & 3.6 & -6.1 \\
\hline United States $\ldots \ldots \ldots \ldots \ldots \ldots \ldots \ldots \ldots \ldots$ & 11,203 & 10,952 & -2.2 \\
\hline Foreign $\ldots \ldots \ldots \ldots \ldots \ldots \ldots \ldots \ldots \ldots \ldots \ldots \ldots \ldots \ldots$ & 4,622 & 4,648 & 0.6 \\
\hline \multirow[t]{2}{*}{ 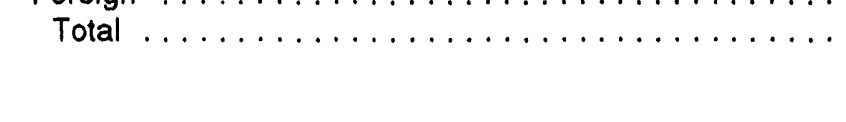 } & 15,825 & 15,600 & -1.4 \\
\hline & \multicolumn{2}{|c|}{ (percent) } & \\
\hline \multicolumn{4}{|l|}{ Refinery Utilization Rate } \\
\hline United States $\ldots \ldots \ldots \ldots \ldots \ldots \ldots \ldots \ldots \ldots$ & 86.9 & 88.3 & -- \\
\hline Foreign $\ldots \ldots \ldots \ldots \ldots \ldots \ldots \ldots \ldots \ldots$ & 80.4 & 79.9 & -- \\
\hline
\end{tabular}

ancludes refining and marketing transport.

-. = Not meaningful.

Note: Sum of components may not equal total due to independent rounding. Percent changes were calculated trom unrounded data.

Source: Energy Information Administration, Form EIA-28.

${ }^{54}$ International Energy Agency, Oil Market Report, April 6, 1993.

${ }^{55}$ International Petroleum Finance, Feb. 28, 1992, p. 7, and Exxon Corporation, 1992 Annual Report Supplement, p. 49.

${ }^{56} 1992$ Mobil Fact Book, p. 65. 
companies, but intense product market competition forced product prices and refining margins down, reducing FRS European earnings.

In Asia, refining margins were higher than in Europe. However, margins were down significantly from their high war-induced levels of 1991 (Figure 20). In 1991, Saudi Arabia had been forced to import rather than export certain refined products, while Kuwait's refining capacity was out of commission. The loss of Saudi and Kuwaiti refined products increased prices, to the benefit of other sellers of refined products. In early 1991, Operation Desert Storm ended, and product prices settled down to lower pre-war levels. Nonetheless, in 1992 Kuwait recovered barely half of its pre-war refinery capacity, leaving its Asian market open to its competitors. ${ }^{57}$ One of these competitors, Caltex, the Chevron/Texaco joint venture operating in Asia, earned $\$ 720$ million after taxes, down from 1991 levels, but higher than in $19900^{58}$ Exxon's product volumes sold in the Asia/Pacific region increased 6.5 percent from 1991, despite the sale of its marketing network in Australia in $1991 .^{59}$ Robust economic growth in countries such as Thailand, Indonesia, South Korea, China, and others provides an expanding market for refined products.

\section{Capital Expenditure for Refining and Marketing}

Despite an overall decline in profits of 60 percent between 1991 and 1992, additions to investment in place for FRS companies' worldwide refining and marketing operations fell by only 6 percent, to $\$ 11$ billion (Table 27). Notably, direct investments in U.S. refining operations rose 8 percent. The only significant reductions in investment expenditures were in U.S. petroleum marketing operations.

\section{U.S. Refining Investment Upgrading}

Much of the 8-percent increase in FRS refinery investment in the United States in 1992 was for upgrading refining facilities in order to yield more gasoline and diesel and to make cleaner-burning fuels in compliance with recent environmental regulations.

\section{Flgure 20. Forolgn Rofining Margins}

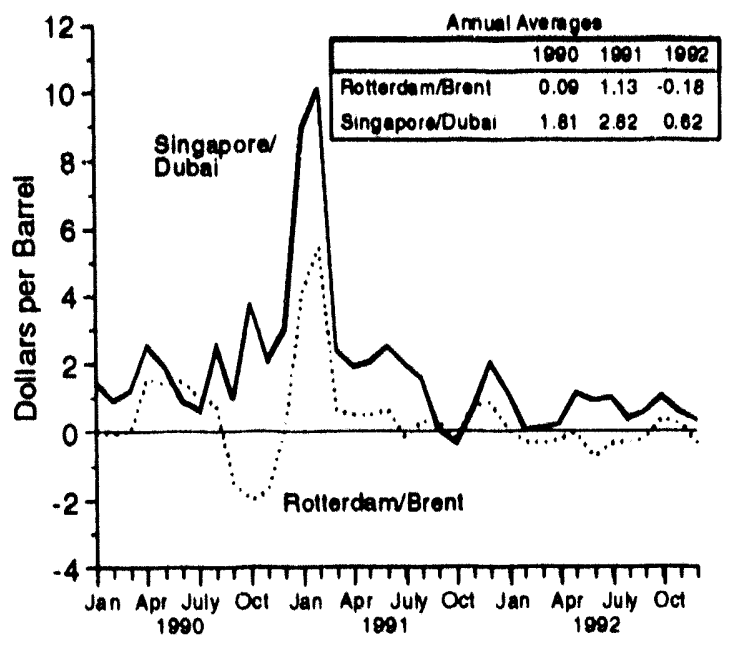

Note: Refining margin is defined as netback crude oil price less spot crude oll price. Netback price is calculated by multiplying the spot price of each refined product by its percentage share in the yield of a barrel of crude oil. Transport and out-of-pocket refining costs are then subtracted to arrive at netback price.

Source: Petroleum Market Intelligence, August 30, 1990; September 6, 1991; April 2, 1992; and February 4, 1993.

Amerada Hess, for instance, reported that a 90,000 barrel-per-day fluid catalytic cracking unit was under construction at the company's Virgin Islands refinery. ${ }^{60}$ The new cracking unit, in addition to other recent refinery upgrades, is expected to increase yields of gasoline at the Virgin Islands refinery by 50,000 to 132,000 barrels per day. Hess reported that the refinery will produce oxygenated and reformulated gasolines. Companies making sizable increases in refining investments include Mobil, which reported that its 1992 refining capital expenditures were directed both toward upgrades and refinery expansion. This was particularly evident at Mobil's Beaumont, Texas refinery where distillation capacity rose from 275,000 to 310,000 barrels per day between 1991 and 1992, while the refinery's ability to produce higher-end products from lower-end heavier crude also improved. ${ }^{61}$ In order to increase its low-sulfur diesel production capabilities, BP America installed new hydrorefining units at its Ferndale, Washington and its Toledo, Ohio refineries. ${ }^{62}$

\footnotetext{
${ }^{57}$ Platt's Oilgram News, December 7, 1992.

"2. Texaco, Inc., Form 10-K, p. 6.

${ }^{59}$ Exxon Corporation, 1992 Annual Report Supplement, p. 51.

${ }^{60}$ Amerada Hess Corporation, Amerada Hess 1992 Annual Report, $\Gamma 21$.

${ }^{61}$ Mobil Annual Report 1992, p. 11.

62BP America, 1991 Annual Report, p. 18.
} 
Despite increased FRS refining capital expenditures, FRS octane/unleaded boosting capacity fell from 4.6 to 4.5 million barrels per day between 1991 and 1992, while FRS heavy/sour crude capacity declined from 8.4 to 8.2 million barrels per day. Chevron's shutdown of its Port Arthur, Texas refinery along with Shell's sale of its Wilmington, California refinery accounts for much of these declines. One reason given for the Port Arthur shutdown was that the refinery lacked advanced facilities for the manufacture of MTBE and ETBE. ${ }^{63}$ In the United States, ${ }^{64}$ FRS companies operated 82 refineries in 1992, 6 fewer than in 1991. The 18 refiners reporting to the FRS for 1992 had 79,000 fewer barrels per day U.S. capacity at the end of 1992 than at the beginning that year..$^{65}$

\section{Marketing Investment and Upgrading In the United States}

Throughout most of the last decade, marketing investments in the United States were a growing target of FRS company capital expenditures. At the same time, FRS companies have been consolidating their petroleum marketing activities, with an emphasis on increasing investment in high-volume service stations and selling or closing low-volume retail operations. This consolidation has mostly involved a reduction in FRS company lessee-dealer and owner-operated stations. The FRS companies maintained a lessee-dealer, and owner-operator network of 90,407 stations in 1982 versus 36,631 stations in $1992{ }^{66}$ In 1982, FRS companies sold, on average, 26,000 gallons of gasoline per month per station through their dealer-operated stations. By 1992, FRS dealer-operated stations averaged 73,000 gallons of gasoline per month per station. In comparison, FRS companies have maintained a fairly steady number of company-operated stations. In 1982, the FRS companies owned and operated 10,739 stations versus 10,745 in 1991. A consolidation was, however, evident in 1992, as the number of company-operated stations declined by 810 (or by 163 , excluding the effects of Total's departure from the FRS survey group). ${ }^{67}$ Most FRS companies shed dealer-operated stations in 1992, with the notable exception of Marathon, which added 238 branded outlet stations to its marketing network. ${ }^{68}$ The average daily volume of gasoline sold per month at company-operated stations has also remained fairly steady throughout the past decade, although always at a much higher level than the volume sold by dealer-operated stations. In 1992, the average monthly volume of gasoline sold per company-operated station equaled 123,000 gallons.

The attractiveness of FRS marketing investments has diminished in recent years. In both 1991 and 1992, the FRS companies reduced their marketing capital expenditures. This may be, in part, related to recent environmental regulations. FRS marketing retrenchment has been particularly severe in the California retail gasoline market, where environmental standards affecting mobile sources of pollution are stricter than the national standards specified in the CAAA. In 1992, Exxon announced that it would withdraw from the retail gasoline market in the Los Angeles area, while BP America announced that it intended to sell 300 service stations located in Northern California and Florida. ${ }^{69}$ BP America's planned withdrawal marks a particularly striking turnaround, for until recently the company viewed these two areas as major targets of expansion. BP America had acquired most of its West Coast marketing operations as recently as 1989 , shortly after purchasing an 85,000 barrel-per-day refinery in Ferndale, Washington. ${ }^{70}$ Further, in their 1989 Operations Report, BP America stated "our retail strategy for 1990 and beyond emphasizes investments to build on our West Coast standing, (and) to achieve a first-tier position in the Southeast. . . . ${ }^{\prime \prime 1}$ In 1993, BP America agreed to sell its Ferndale, Washington refinery to Tosco along with the company's retail marketing assets located in Washington and Oregon. ${ }^{72}$ Also during 1992, Unocal announced that it would no longer market diesel fuel in the California market. Unocal stated that its departure from the California diesel market would save the company $\$ 100$ million in capital outlays. ${ }^{73}$

\footnotetext{
${ }^{63}$ Oxy-Fuel News, May 31, 1993, p. 9.

${ }^{64}$ For FRS purposes, the United States includes Puerto Rico and the Virgin Islands.

${ }^{65}$ Measured from end of 1991 to end of 1992 , the decrease was 251,000 barrels per day (as shown in Table 27), largely due to the departure of Total Petroleum from the FRS survey group.

${ }^{66}$ Energy Information Administration, Form EIA-28.

${ }^{67}$ The FRS companies reported 810 fewer company-owned stations in 1992, almost all of which was due to the loss of Total Petroleum from the FRS survey.

${ }^{68}$ National Petroleum News, Mid-June, 1992, p. 40; and, Mid-June 1993, p. 38.

${ }^{69}$ The Financial Times, June 26, 1992, p. 27.

${ }^{70}$ BP America Operations Report 1989, p. 15.

${ }^{71} B P$ America Operations Report, 1989, p. 16.

${ }^{n}$ The Wall Street Journal, September 28, 1993, p. B2.

${ }^{73}$ The Wall Street Journal, June 2, 1992, p. A9.
} 
Other noteworthy FRS marketing developments in 1992 were concentrated in the mid-Atlantic region and in the Southeast. These included Chevron's acquisition of 69 Shell service stations in the Atlantic Coast area, and the exchange of 60 mid-Atlantic outlets for Exxon outlets in Southeast Florida. ${ }^{74}$ Unocal said it will cease marketing gasoline in the Southeast altogether, ${ }^{75}$ while Ashland initiated the sale of 51 Florida retail outlets. ${ }^{76}$ Sun withdrew from gasoline marketing in Oklahoma. Missouri, and Iowa because of its earlier decision to reconfigure its Tulsa refinery to focus on the production of lubricants. ${ }^{77}$ This withdrawal reduced Sun's number of dealer-owned stations from 4,180 to 3,744 .

Although the overall level of FRS investment in U.S. refining/marketing declined between 1991 and 1992, many FRS companies continued to report increased efforis on the modernization and upgrading of service stations. For instance, in just the last few years, gasoline marketers have been introducing point of sales electronic payment systems. It appears that electronic payment systems may be well on their way toward becoming a common fixture at gas stations. Several of the FRS companies, including Amoco, ARCO, BP America, Chevron, Exxon, Mobil, Shell, Sun, and Texaco have committed resources to the intioduction of point of sales systems. ${ }^{78}$ Mobil announced that it would introduce electronic payment systems at 2,000 Mobil filling stations by the end of $1993 .^{79}$

\section{Foreign Refining Investments}

The FRS companies profited to an increasing extent from their foreign refining/marketing operations within two years of the collapse of oil prices in 1986 (Figure 19). ${ }^{80}$ After reaching a trough in the early 1980 's, demand for refined products outside the United States grew at an average annual rate of 6 percent, and the capacity utilization rate increased substantially (Table 28) ${ }^{81}$ The pace of growth varied across regions, with areas outside Europe consistently increasing in relative importance for petroleum. For example, Exxon's sales in Europe grew at an average annual rate of 1 percent after 1982, and its Other Eastern Hemisphere sales grew by 5 percent annually. ${ }^{82}$ Mobil's sales to Europe grew by 2 percent annually, while Mobil's sales to Other Eastern Hemisphere markets grew by 3 percent annually. Caltex's sales revenues grew 10 percent per year on average after $1986 .^{83}$ Growth in sales of refined products overseas has contributed to the general upward trend in the FRS companies' foreign refining and marketing profitability since 1986 (Figure 19).

\footnotetext{
${ }^{74}$ Herold's Oil Headliner, December 11, 1992.

${ }^{75}$ Energy Alert, March 3, 1992.

${ }^{76}$ Ashland Oil, Inc., 1992 Annual Report, p. 40.

${ }^{7}$ Sun Company, Inc., 1992 Annual Report, p. 15.

${ }^{78}$ National Petroleum News, July 1993, p. 4.

${ }^{79}$ PR Newswire Association, Inc., June 8, 1993, p. 1.

${ }^{80}$ Substantial divestitures of overseas refining operations occurred in the early 1980's. The majority of FRS (consolidated) refining capacity was in Europe. For a variety of reasons, in the early 1980's, prospects for selling refined products in Western Europe appeared dismal. The two oil crises had accelerated the construction of nuclear and coal-fired electric utilities, reducing demand for heavy fuel oil. Further, demand from the residential, commercial, and industrial sectors for heating fuel was increasingly met by natural gas from the North Sea, the Netherlands, and the former Soviet Union. Prospects of weak demand induced Exxon to shut down refineries in the United Kingdom and France in 1983, and sell refining and marketing operations in Sweden and West Germany in 1985, although Exxon upgraded its remaining refineries. Mobil closed its Amsterdam refinery in 1982, and reduced capacity at refineries in the United Kingdom, Italy, and France. Chevron sold nearly all its European downstream assets to Texaco in 1984 . Among the smaller FRS companies, Coastal disposed of its 4 European refineries in 1985, after giving up efforts to upgrade conversion capacity and reduce crude capacity. Gulf Oil sold its continental European refining and marketing operations to Kuwait Petroleum in 1983, the year before Gulf was acquired by Chevron. The divestitures tapered off after 1986, and the FRS companies concentrated investment efforts on upgrading remaining capacity.

${ }^{81}$ British Petroleum, p.l.c., BP Statistical Review of World Energy, 1992, p. 10

${ }^{82}$ Exxon, Financial and Statistical Supplement to the Annual Report, 1987, p. 42, 1992, p. 51; Mobil Corporation, Financial and Operating Statistics, 1986, p. 25, and 1992 Mobil Fact Book, p. 62.

${ }^{83}$ Chevron Corporation, Form 10-K 1988, "Caltex Group of Companies, Combined Financial Statements and Schedules," p. 4; Form 10-K 1991, "Caltex Group of Companies, Combined Financial Statements and Schedules," p. 5; and Texaco, Form 10-K 1992, "Caltex Group of Companies, Combined Financial Statements and Schedules," p. 6.
} 
Table 28. FRS Foreign Refining Capacity, Selected Years, 1974-1992

\begin{tabular}{|c|c|c|c|c|}
\hline Items & 1974 & 1981 & 1986 & 1992 \\
\hline Number of FRS Companies with Foreign Refineries . . . . & 13 & 11 & 7 & 7 \\
\hline Total FRS Capacity (Thousand Barrels per Day) . . . . . . . & 9,269 & 7,990 & 4,638 & 4,648 \\
\hline Top Four FRS Capacity (Thousand Barrels per Day) . . . . . & 7,606 & 6,622 & 4,262 & 4,255 \\
\hline Capacity Utilization (Percent) . . . . . . . . . . . . . . & 78 & 64 & 67 & 80 \\
\hline 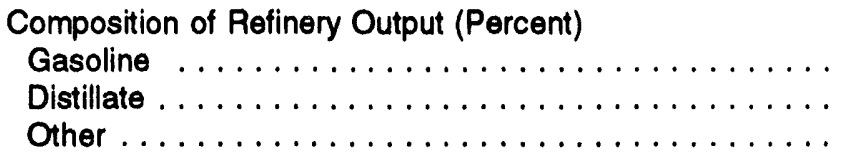 & $\begin{array}{l}\text { NA } \\
\text { NA } \\
\text { NA }\end{array}$ & $\begin{array}{l}22 \\
35 \\
44\end{array}$ & $\begin{array}{l}29 \\
37 \\
34\end{array}$ & $\begin{array}{l}30 \\
42 \\
28\end{array}$ \\
\hline
\end{tabular}

NA $=$ Not available.

Note: Sum of components of refinery output may not equal 100 percent, due to independent rounding.

Source: Energy Information Administration, Form EIA-28.

\section{Investment in 1992}

In the past, foreign demand for refined products was primarily for heavier products and distillate. Consequently, refineries producing for non-U.S. markets did not need elaborate downstream conversion capacity (See the box below on refinery configurations). However, environmental concerns overseas have in recent years prompted foreign refiners, including FRS companies, to invest in downstream capacity. The near-record $\$ 3.5$ billion spent by FRS companies on foreign refining and marketing investment in 1992 (Appendix B, Table B11) expanded conversion capacity in Western Europe and Asia, in addition to increasing capacity and marketing infrastructure in Asia and Eastern Europe.

\section{Refinery Configurations Reflect Product Demand}

Americans consume more gasoline than any other refined product. To meet this demand, refineries in the United States convert 46 percent of a barrel of crude oil into gasoline. ${ }^{a}$ This requires downstream units to break up the heavier crude fractions into lighter fractions, and to increase octane. Refineries in other countries use less elaborate downstream configurations, since the markets they serve demand less gasoline and other light products. In most other parts of the world, gasoil (distillate) and heavier products such as residual fuel oil make up the majority of refined product demand (Table 29).

Since a European or Asian refinery product slate includes much less gasoline, catalytic cracking is only 14 percent of a barrel of crude distillation capacity in Western European refineries, and 9 percent in Asian refineries, compared to 31 percent in North American refineries (Table 30). Investment in conversion capacity depends on supply as well as demand. Eastern European refineries, supplied by low-sulfur Soviet crude, lack hydrorefining desulfurization units. ${ }^{\text {b }}$

aEnergy Information Admiuistration, Petroleum Supply Annual, DOE/EIA-0340(92)/1, Table 19.

bCambridge Energy Research Associates, Private Report, "Oil and Eastern Europe: The Promise of Reintegration," March 1992, p. 7. 
Table 29. Worldwide Consumption of Refined Products, 1990

\begin{tabular}{|c|c|c|c|c|c|}
\hline \multirow[b]{2}{*}{ Reglon } & \multirow{2}{*}{$\begin{array}{c}\text { All Rofined Products } \\
\text { (thousand barrels per } \\
\text { calendar day) }\end{array}$} & \multicolumn{4}{|c|}{ Percent of Total } \\
\hline & & $\begin{array}{l}\text { Motor } \\
\text { Gascollne }\end{array}$ & $\begin{array}{l}\text { Distillato } \\
\text { Fuol OII }\end{array}$ & $\begin{array}{l}\text { Residual } \\
\text { Fuel OII }\end{array}$ & $\begin{array}{c}\text { Other } \\
\text { Products }\end{array}$ \\
\hline North America $\ldots \ldots \ldots \ldots \ldots \ldots \ldots$ & 20,410 & 40.4 & 17.8 & 9.3 & 32.5 \\
\hline Asia/Pacific & 13,614 & 16.0 & 25.7 & 22.9 & 35.3 \\
\hline Westem Europe & 12,964 & 22.8 & 33.9 & 18.1 & 25.2 \\
\hline Eastern Europe/ClS $\ldots \ldots \ldots$ & 10,007 & 20.7 & 23.1 & 32.4 & 23.8 \\
\hline Middle East and Africa $\ldots \ldots \ldots \ldots \ldots$ & 5,565 & 18.0 & 27.7 & 27.4 & 26.9 \\
\hline South America and Caribbean . ........ & 3,595 & 25.9 & 26.5 & 20.4 & 27.2 \\
\hline
\end{tabular}

Source: Energy Information Administration, International Energy Annual 1991, DOE/EIA-0219(91), Table 18.

Table 30. Worldwide Downstream Refining Capacity, January 1, 1993

\begin{tabular}{|c|c|c|c|c|c|c|}
\hline \multirow[b]{2}{*}{ Region } & \multirow{2}{*}{$\begin{array}{c}\text { Crude Diatillation } \\
\text { Capacity } \\
\text { (thousand barrels } \\
\text { per calendar day) }\end{array}$} & \multicolumn{5}{|c|}{ Downstream Capacity as a Percont of Crude Distllation Capacity } \\
\hline & & $\begin{array}{c}\text { Vacuum } \\
\text { Distlllation }\end{array}$ & $\begin{array}{l}\text { Catalytic } \\
\text { Cracking }\end{array}$ & $\begin{array}{l}\text { Catalytic } \\
\text { Reforming }\end{array}$ & $\begin{array}{l}\text { Hydro- } \\
\text { cracking }\end{array}$ & $\begin{array}{l}\text { Hyciro: } \\
\text { refining }\end{array}$ \\
\hline North America $\ldots \ldots \ldots \ldots$ & 18,605 & 43.1 & 31.3 & 22.2 & 7.8 & 13.1 \\
\hline Asia/Pacific & 13,395 & 23.2 & 8.6 & 9.7 & 2.6 & 14.4 \\
\hline Westem Europe . . . . . . . . . . & 14,384 & 36.1 & 14.0 & 15.5 & 3.2 & 14.6 \\
\hline Eastern Europe/CIS . . . . . . . & 12,873 & 26.1 & 4.3 & 2.3 & 0.5 & 9.6 \\
\hline Middle East and Africa $\ldots \ldots \ldots$ & 7,882 & 21.3 & 4.9 & 11.1 & 3.9 & 6.3 \\
\hline South America and Caribbean . . & 6,047 & 43.2 & 16.5 & 5.7 & 1.2 & 4.3 \\
\hline
\end{tabular}

Source: Oil and Gas Joumal, December 21, 1992.

Western Europe: Environmentalism. New environmental legislation will shift refined product demand in Western Europe to higher grades of gasoline and to low-sulfur distillate. The European Community (EC) has mandated that any vehicle sold after January 1993 must have a catalytic converter, which requires unleaded gasoline. In 1991, about 43 percent of the European members of the Organization for Economic Cooperation and Development's (OECD) gasoline sales were unleaded, compared with 98 percent in the
United States, where, since 1970, Federal legislation has restricted the use of lead in gasoline. ${ }^{84}$ Anticipating growing demand for unleaded gasoline, Exxon is adding an alkylation unit to its refinery in France. ${ }^{85}$ Mobil is constructing an isomerization unit at its U.K. refinery, to manufacture more (and higher-octane) gasoline, and has added an MTBE unit to its refinery in Germany. ${ }^{86}$ Texaco has commissioned an isomerization unit at its Wales refinery. ${ }^{87}$

\footnotetext{
${ }^{\text {B4}}$ Organization for Economic Cooperation and Development, International Energy Agency, Oil and Gas Information, and Energy Information Administration, Petroleum Supply Annual, DOE/EIA-0340(92)/1, Table 3.

${ }^{85}$ Exxon Corporation, 1992 Annual Report, p. 14.

${ }^{86} 1992$ Mobil Fact Book. p. 54.

${ }^{87}$ Texaco Inc., Annual Report, p. 16.
} 
In the past, Western European environmental concerns were focused on reducing sulfur emissions from diesel fuel. The sulfur content of refined products consumed in Western Europe was reduced by over 60 percent during the 1980 's, to meet the EC limit of 0.2-percent sulfur in gasoil and diesel fuel. The EC countries plan further reductions, to 0.05 percent over the next several years. ${ }^{88}$ Among the FRS companies, Exxon is adding a hydrocracker to its Rotterdam refinery to produce low-sulfur diesel fuel. ${ }^{89}$

Eastern Europe: Anticipating Demand. The prevalence of long lines and shortages at outdated service stations in Eastern Europe presents opportunities for Western product marketers. To reduce the risk of investing in Eastern Europe, the European Energy Charter, signed in December 1991, between Western and Eastern European nations, defines property rights and protects foreign investment. ${ }^{90}$ The Energy Charter is intended to create an open market in energy, and bring more efficient and cleaner Western refining and marketing technology to Eastern Europe.

Despite the Energy Charter, refinery investment in Eastern Europe is risky. One area of particular concern to foreign investors is that in purchasing East European refineries, they will be assuming all future environmental cleanup obligations at those facilities. Further, Eastern European refineries lack advanced downstream capacity, storage, and adequate port facilities. Many are tied by crude oil pipelines to the former Soviet Union. ${ }^{91}$ As a consequence, investors are cautious about pursuing projects in Eastern European refining operations. At the same time, chronic refinery overcapacity in Western Europe would appear to make Eastern Europe an increasingly attractive export market.
Early indications suggest interest in developing Eastern European marketing subsidiaries. ${ }^{92}$ New marketing outlets can promote early brand recognition to establish a market position for the time when more Eastern Europeans will own cars and use better roads. Exxon is committed to build or modernize 150 stations in Eastern Europe, including new stations in eastern Germany, Poland, and Hungary. ${ }^{93}$ DuPont's Conoco is expanding into eastern Germany and Czechoslovakia, to complement its ownership interest in a refinery in Karlsruhe, Germany. Other (non-FRS) Western companies have opened retail sites, including BP in eastern Germany.

Asia-Pacific: Growing Economies. Refined product demand in the Asia-Pacific region is expected to grow over 6 percent annually, to 12 million barrels per day by the year $2000 . .^{94}$ The FRS companies are involved in meeting this demand. Caltex, one of the most active refiner/marketers in the Pacific area, has begun a 130,000-barrel-per-day refinery in Thailand in a joint venture with the Thai government, and will upgrade its 500 retail outlets. ${ }^{95}$ Caltex also plans to expand crude capacity in Singapore, and upgrade capacity in Singapore, Japan, and the Philippines. Exxon has also allocated investment funds to the Pacific Basin region. In 1992, the company built 80 new service stations in Southeast Asia, and plans to double the size of its Thailand refinery by $1995 .{ }^{96}$

Asian governments are also concerned with the effect of oil products on the environment. Japan has instituted new low-sulfur requirements for diesel fuel, and the Exxon/Mobil Japanese affiliate, Tonen, will be installing desulfurization units at two refineries. ${ }^{97}$ Caltex reports that it has begun phasing out leaded gasoline in most of its marketing areas. ${ }^{98}$

\footnotetext{
${ }^{88}$ Petroleum Times Price Reports, "Refining and the environment: Counting the cost of product quality changes; World Refining Survey, 1993," May 1, 1993, p. S4; and Platt's Oilgram News, "Europia Seeks Analysis of Costs of Regulation," December 7, 1992, p. 2.

${ }^{89}$ Exxon Corporation, 1992 Annual Report, p. 14.

90" Energy Charter Charts Changes," Petroleum Economist, November 1991, p. 8.

${ }^{91}$ Cambridge Energy Research Associates, Private Report, "Oil and Eastern Europe: The Promise of Reintegration," March 1992, pp. 7-9.

${ }^{92}$ Cambridge Energy Research Associates, Private Report, "Oil and Eastern Europe: The Promise of Reintegration," March, 1992, p. 1.

${ }^{93}$ Exxon, 1991 Annual Report Supplement, p. 39.

${ }^{94}$ International Petroleum Finance, "Caltex Continues Upward Spending on New Refirieries," Dec 16, 1992, p. 8.

${ }^{95}$ Texaco, Inc., Financial and Operational Supplement, 1992. p. 9.

${ }^{96}$ Exxon Corporation, 1992 Annual Report Supplement, p. 44.

${ }^{97} 1992$ Mobil Fact Book, p. 55.

${ }^{96}$ Chevron, Annual Report, 1992, p. 19.
} 
Latin America: Private Capital. Refining and marketing in Latin American countries provide opportunities for expansion, as governments begin to seek private capital and to decontrol markets. Argentina's sale of stock in its state oil company in 1993 was perhaps the most dramatic example of recent Latin American privatizations. ${ }^{99}$ Ecuador has begun selling refining, transportation, and distribution assets. ${ }^{100}$ Venezuela has offered foreign investors joint ventures with Petroleos de Venezuela SA (PDVSA). ${ }^{101}$ In 1992, the Mexican government broke up the state oil company, Petroleos Mexicanos (Pemex), into four operating units, expecting each to turn a profit. ${ }^{102}$ The FRS companies have begun downstream joint ventures with national oil companies, although not to the same extent as in exploration and development (See Chapter 4). Mobil and Conoco are negotiating a refining joint venture with PDVSA. ${ }^{103}$

\section{Transportation}

For the FRS companies as a group, petroleum transportation represents a relatively small part of total energy operations. About 10 percent of net petroleum investment in place and additions to investment are allocated to transportation lines of business (Appendix B, Table B11). Petroleum transportation includes natural gas and liquids pipelines, and international marine operations.

\section{Natural Gas Pipelines}

The FRS companies' net income from interstate natural gas pipeline operations was $\$ 633$ million (excluding unusual items) in 1992, or 10 percent more than in 1991 (Table 31). The magnitude of the increase, however, does not reflect the substantial change in the composition of those operations.
In December of 1992, FRS natural gas pipeline companies accounted for 21 percent of total U.S. natural gas transportation volume. ${ }^{104}$ The natural gas pipeline segment of the FRS companies registered a 37-percent increase in revenue and a 50-percent increase in operating expenses between 1991 and 1992 (Table 31), due largely to the addition of Enron as an FRS respondent company for 1992. Enron has two interstate pipeline subsidiaries, Northern Natural Gas Pipeline (Northern) and Transwestern Pipeline. Northern serves the upper midwest and stretches from Texas to Michigan's Upper Peninsula and the Canadian Border. Transwestern serves principally the California market. ${ }^{105}$ The addition of Enron to the FRS group was partially offset by the elimination of Burlington's El Paso Natural Gas subsidiary. ${ }^{106}$ In June 1992, Burlington spun off El Paso Natural Gas to its shareholders, thereby concentrating the future focus of its operations on oil and gas exploration and production. $^{107}$

The FRS companies involved in interstate natural gas pipelines continued to adjust, in 1992, to new market and regulatory realities brought about by Federal Energy Regulatory Commission (FERC) Orders. In April 1992, FERC issued Order 636, known as the "Restructuring Rule." FERC Order 636 requires pipelines to further "unbundle" natural gas transportation services by offering transportation, sales, and storage services separately. Although FERC Order 636 has been challenged on appeals and by petitions for rehearing, the notion of open access is now widely accepted in the natural gas interstate market and fundamentally alters the way that natural gas is sold, transported, and stored in the United States. ${ }^{108}$ Between 1991 and 1992, natural gas pipelines continued to shift the focus of their operations to transportation and away from sales. Excluding Burlington, natural gas sales decreased 10 percent in 1992, while volumes transported rose 5 percent. ${ }^{109}$

\footnotetext{
${ }^{99}$ New York Times, June 28, 1993, "Argentina's Oil Company Going Public," p. 1.

${ }^{100}$ National Petroleum News, "Move to Free Market Opens Doors in Mexico, South America," November, 1992, p. 39.

${ }^{101}$ National Petroleum News, "Move to Free Market Opens Doors in Mexico, South America," November, 1992, p. 39.

${ }^{102}$ National Petroleum News, "Move to Free Market Opens Doors in Mexico, South America," November, 1992, p. 38.

${ }^{103}$ National Petroleum News, "Move to Free Market Opens Doors in Mexico, South America," November, 1992, p. 38.

${ }^{104}$ Energy Information Administration, Natural Gas Monthly, DOE/EIA-0130(93/03)(Washington, DC, March 1993 ), Table 13.

${ }^{105}$ Enron Corporation, 1992 Securities and Exchange Commission Form 10-K, pp. 2 and 3.

${ }^{106}$ Although the divestiture dropped El Paso Natural Gas from the FRS survey, due to its oil and natural gas operations, El Paso's former parent, Burlington Resources remains an FRS company.

${ }^{107}$ El Paso Natural Gas Company, 1992 Annual Report, Letter to Shareholders.

${ }^{108}$ Cambridge Energy Research Associates, Unfinished Business: North American Gas Strategies After Order 636, 1992 Edition, Cambridge, MA, 1992), p. 3.

${ }^{109}$ Occidental Petroleum Corporation, Supplement to the 1992 Annual Report, p. 31.; Coastal Corporation, 1992 Securities and Exchange Commission Form 10-K, p. 2.; and Enron Corporation, 1992 Securities and Exchange Commission Form 10-K, p. 20.
} 
Table 31. Financial Items for Transportation for FRS Companies, 1991-1992

\begin{tabular}{|c|c|c|c|}
\hline Financial Items & 1991 & 1992 & $\begin{array}{c}\text { Percent Change } \\
1991-1992\end{array}$ \\
\hline & \multicolumn{2}{|c|}{ (million dollars) } & \\
\hline \multicolumn{4}{|l|}{ Natural Gas Pipelines ${ }^{a}$} \\
\hline Revenues.......... & 4,891 & 6,685 & 36.7 \\
\hline Operating Expenses $\ldots \ldots \ldots \ldots \ldots \ldots \ldots \ldots \ldots$ & 3,936 & 5,919 & 50.4 \\
\hline Operating Income $e^{b} \ldots \ldots \ldots \ldots \ldots \ldots \ldots$ & 907 & 781 & -13.9 \\
\hline Net Income ${ }^{b} \ldots \ldots \ldots \ldots$ & 578 & 633 & 9.5 \\
\hline Additions to Investment in Place ${ }^{c}$ & 668 & 592 & -11.4 \\
\hline \multicolumn{4}{|l|}{ Liquids Pipelines ${ }^{d}$} \\
\hline Revenues . . . . . . . & 5,045 & 5,019 & -0.5 \\
\hline Operating Expenses & 3,042 & 3,127 & 2.8 \\
\hline Operating Income ${ }^{b}$. & 2,048 & 1,896 & -7.4 \\
\hline Net Income $\theta^{b} \ldots \ldots \ldots \ldots \ldots$ & 1,422 & 1,400 & -1.5 \\
\hline Additions to Investment in Place ${ }^{\mathrm{c}} \ldots \ldots \ldots \ldots \ldots$ & 620 & 413 & -33.4 \\
\hline \multicolumn{4}{|l|}{ International Marine } \\
\hline Revenues $\ldots \ldots \ldots \ldots \ldots \ldots \ldots \ldots \ldots \ldots$ & 3,067 & 2,415 & -21.3 \\
\hline Operating Expenses $\ldots \ldots \ldots \ldots \ldots \ldots \ldots \ldots \ldots$ & 2,886 & 2,451 & -15.1 \\
\hline Operating Income $\ldots \ldots \ldots \ldots \ldots \ldots \ldots \ldots \ldots$ & 181 & -36 & .. \\
\hline Net Income $e^{b} \ldots \ldots \ldots \ldots \ldots \ldots \ldots$ & 285 & -21 & -- \\
\hline Additions to Investment in Place ${ }^{c} \ldots \ldots \ldots \ldots$ & 294 & 223 & -24.1 \\
\hline
\end{tabular}

${ }^{a}$ Data are for FRS companies with pipeline assets primarily in natural gas transmission.

${ }^{b}$ Excludes special charges taken by FRS companies.

${ }^{c}$ Measured by additions to property, plant, and equipment (PP\&E) plus additions to investments and advances.

dData are for FRS companies with pipeline assets primarily in liquids pipelines.

Source: Energy Information Administration, Form ElA-28.

The impact of Order 636 on the structure of the natural gas transmission industry will continue to be shapea in the months ahead because the Order is not expected to be fully implemented until the winter heating season of 1993-94. ${ }^{110}$

\section{Liquids Pipelines}

In contrast to natural gas pipelines, liquids pipelines' financial performance and operating developments were relatively stable between 1991 and 1992. Both revenue and net income were down slightly (Table 31).
Developments in the Trans Alaskan Pipeline System (TAPS) are central to the financial performance of the FRS companies' liquids pipelines. ${ }^{111}$ The three FRS companies accounting for 92 percent of TAPS ownership (ARCO, BP America, and Exxon) ${ }^{112}$ account for 57 percent of the FRS companies' revenue from liquids pipelines. The 3-percent decline in total U.S. crude oil production in $1992^{113}$ coincided with the reduction in output from Prudhoe Bay in Alaska. Prudhoe Bay is the nation's largest oil field and accounts for the majority of TAPS throughput. The Prudhoe Bay field has entered its mature phase and production levels began to decline in 1989. However, in

\footnotetext{
${ }^{110}$ Based on a review of company disclosures, FRS companies' expected schedules of compliance with Order 636 appear as follows: Transwestern and Northern, Enron's subsidiaries, will fully implement FERC Order 636 in February and November 1993, respectively; Coastal's subsidiaries, ANR Pipeline, will fully implement Order 636 in November 1993, while Colorado Interstate Pipeline submitted compliance filing with FERC in October 1992 and is awaiting approval; Natural Gas Pipeline, Occidental's subsidiary, will fully implement FERC Order 636 in December 1993.

${ }^{111}$ The following FRS companies together own 100 percent of the Trans Alaska Pipeline System: Amerada Hess Corporation, Atlantic Richfield Corporation (ARCO), BP America, Exxon Corporation, Mobil Corporation, Phillips Petroleum Company, and Unocal Corporation. Source: Energy Alert, April 3, 1992.

${ }^{112}$ U.S. News and World Report, October 25, 1993, p. 38.

${ }^{113}$ Energy Information Administration, Monthly Energy Review, DOE/EIA-0035(93/09(Washington, DC, September 1993$)$, p. 48.
} 
1990, the largest producers of Alaskan oil installed the first phase of a gas handling system and reservoir stimulation program, GHX-1, which maintained production levels in 1990 and 1991. In spite of this, net production of Prudhoe Bay oil declined by 48,000 barrels a day in 1992, close to the underlying natural decline rate. ${ }^{114}$ Throughput of TAPS declined 4percent in 1992 compared with a 2-percent increase in 1991. Further, tariff rates fell to $\$ 3.26$ per barrel in 1992 from $\$ 3.72$ per barrel in $1991 .^{115}$ A second phase of gas handling expansion, GHX-2, will be installed in 1993 and 1994 at a cost of $\$ 1.3$ billion, and will increase the amount of gas that can be injected into the reservoir. Field production is expected to increase by 100,000 barrels per day by 1995 as a result of the GHX-2 program. ${ }^{16}$

\section{International Marine}

International marine revenues for the FRS companies fell 21 percent in 1992, to $\$ 2.4$ billion, partly due to a decline in tanker freight rates to their lowest level since 1989 (Table 31) ${ }^{117}$ Net income fell from $\$ 285$ million in 1991 to a negative $\$ 21$ million in 1992. The FRS international marine segment's rate of return fell to a negative 1-percent (Figure 21).

A near absence of demand for floating storage in 1992 due to the end of the Persian Gulf War placed serious financial pressure on international marine operations. In 1991, freight rates had increased dramatically due to the increased demand for the use of very large crude carriers (VLCCs) ${ }^{118}$ as floating storage by Saudi Arabia and Iran. ${ }^{119}$ However, when the Persian Gulf War ended, fewer VLCCs were needed for floating storage. In 1992, oil tankers used for floating storage fell by 56 percent from the prior year's level. The consequent surge of available tankers contributed to the 43-percent decline in freight rates in 1992. ${ }^{120}$ Although the overall volume of tankers sailing from the Middle East increased 8 percent, exports from the East Mediterranean continue to be curtailed due to the United Nations' embargo on crude oil exports from Iraq. ${ }^{121}$

\section{Figure 21. Rates of Return for Petroleum Transportation for FRS Companies, 1981-1991}

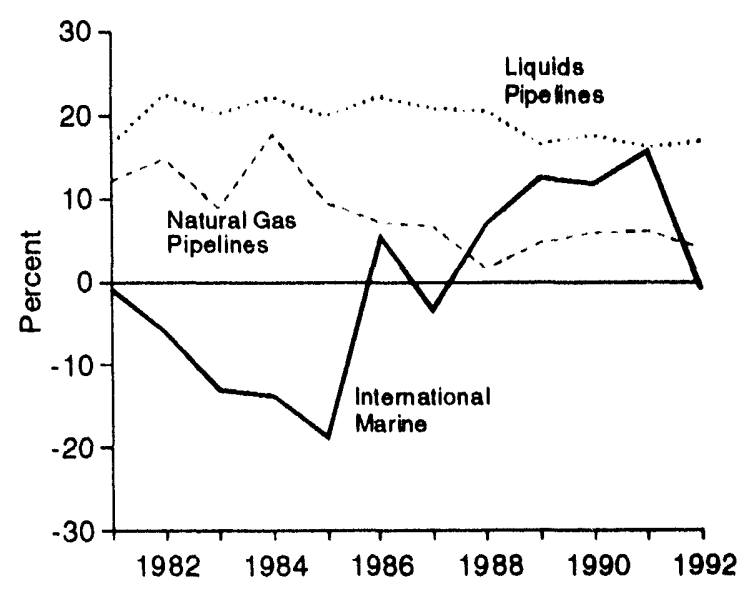

Source: Energy Information Administration, Form ElA-28.

The Oil Pollution and Liability Compensation Act of 1990 was enacted in response to the Exxon Valdez oil spill in 1989 and to other serious spills in offshore California and the Gulf of Mexico. A key provision of the Act is that all newly-built tankers sailing in United States waters have double-hulls by 1995 . It mandates a ban on all single-hull tankers from U.S. coastal waters by 2010 . Additionally, the Act raises the maximum limit on oil-spill liability at the Federal level, and sets no limits on the amount of liabilities states can seek. The Act also requires shippers plying United States waters to present evidence that they have credible oil spill response programs in place. ${ }^{122}$

The Act will tend to accelerate fleet-replacement schedules. Companies will place new orders for doublehull VLCCs before vessels are typically scrapped. However, the new vessels will add capacity to an industry that is already saturated, putting further downward pressure on freight rates.

\footnotetext{
${ }^{114}$ Alaska Business Monthly, Vol. 8, November 7, 1992, p. 53.

${ }^{115}$ Atlantic Richfield Corporation, 1992 Annual Report, p. 6.

${ }^{116}$ British Petroleum Company, 1992 Annual Report on Form 20-F, p. 14; Exxon Corporation, 1992 Form 10-K, p. 8; Atlantic Richfield Corporation, 1992 Form $10-K$, pp. 3 and 4.

${ }^{117}$ Cambridge Energy Research Associates, World Oil Trends, 1993 Edition, (Cambridge, MA, 1993), Table 33.

${ }^{118}$ Very large crude carriers are tankers over 200,000 million deadweight tons (DWT).

${ }^{119}$ Cambridge Energy Research Associates, World Oil Trends,1993 Edition, (Cambridge, MA, 1993), Table 32.

${ }^{120}$ Cambridge Energy Research Associates, World Oil Trends, 1993 Edition, (Cambridge, MA, 1993), Table 34.

${ }^{121}$ Cambridge Energy Research Associates, World Oil Trends, 1993 Edition, (Cambridge, MA, 1993), Table 33.

${ }^{12}$ U.S. Department of Energy, Transporting U.S. Oil Imports: The Impact of Oil Spill Legislation on the Tanker Market, DOE/EP/79095T-H1, (Washington, DC, June 1992), p. 91.
} 
Compliance with the Act could create a financial burden for FRS companies. With depressed freight rates, the profitability of investment in new double-hull tankers is uncertain. ${ }^{123}$ Nevertheless, some FRS companies have invested in double-hull tankers and are committed to invest more in the future. For example, Conoco, a subsidiary of DuPont, has purchased two double-hull tankers and anticipates placing two more in operation by the end of $1993 .{ }^{124}$ Chevron has purchased one double-hull tanker, and expects to acquire two more in 1993 to replace old tankers. ${ }^{125}$ Texaco purchased one double-hull tanker in $1992^{126}$ and Mobil will purchase one double-hull tanker in 1993. ${ }^{127}$

\footnotetext{
${ }^{123}$ The Shell Briefing Service, "The Tanker Industry in the 1990's," Number five, 1991 Edition, p. 7.

${ }^{124} \mathrm{Oil}$ and Gas Journal, January 27, 1992, p. 30.

${ }^{125}$ Oil and Gas Journal, February 8, 1993, p. 36.

${ }^{126}$ Texaco Corporation, 1992 Annual Report, p. 25.

${ }^{12}$ Oil and Gas Journal, September 6, 1993, p. 38
} 


\section{Coal, Alternative Energy, and Research and Development}

\section{Coal}

The ownership of coal assets in the United States changed considerably in 1992. For the FRS companies it was a year of net exit from the industry. Although the remaining FRS coal operations still represent some of the most viable businesses in the U.S. coal industry, the FRS companies' share of U.S. production dropped to 25 percent (Appendix B, Table B1), down from a high of 30 percent reached in 1988. Property, plant, and equipment additions by FRS companies for 1992 amounted to only $\$ 0.6$ billion (Appendix B, Table B11) compared to a high of $\$ 2.8$ billion set in 1981, when expectations of higher energy prices and coal's role as a source of energy for the electricity and industrial sectors were greater than today.

\section{Divestitures}

In recent years, the FRS companies' investments in the coal industry have not provided as good a return as have investments in their core lines of business (Figure 4 and Appendix B, Table B6). Recently held expectations that future turnaround was imminent appear to have diminished. In 1991 and 1992, five FRS companies either sold or announced plans to sell all or a significant portion of their U.S. coal operations. These divestitures followed BP America's sale of its coal assets in 1989 and 1990.

As of December 31, 1991, DuPont transferred its Consolidation Coal Company unit to the joint venture, Consol Energy, Inc., half-owned by DuPont and halfowned by RWE AG of Germany. In 1992, Occidental Petroleum treated its Island Creek Coal subsidiary as a discontinued operation as did Sun Company with its coal subsidiary. Both of these coal-producing subsidiaries were subsequently sold in 1993 . Shell Oil sold its U.S. coal operations to Zeigler Coal in 1992. Burlington Resources sold most of its coal properties to a limited partnership in 1992, retaining a production royalty. Most of the divested coal reserves, apart from Burlington Resources, are located in the higher-cost Eastern region of the U.S, close to export points. This favorable locational feature may have enhanced their value as future sources of supply to European markets as subsidies to local coal production are being scaled back in some European countries.

Interpretation of financial and operating performance for the FRS companies' coal operations for 1991 and 1992 is complicated by the effects of divestitures. Before examining the results for 1992, the main features of each company's transactions for the last two reporting years are summarized as follows:

DuPont. As part of a plan to concentrate DuPont's interests on its core lines of business, principally chemicals, DuPont entered into a joint venture with Germany's Rheinbraun AG to form Consol Energy Inc. (Consol). DuPont sold an approximate 34percent interest in its coal business, principally Consolidation Coal Company, to Rheinbraun, contributing the remainder of its coal business interests to the joint venture and leaving DuPont with a 50-percent equity ownership in the venture. ${ }^{128}$ Although Consol is expected to experience difficulties with marketing future production from its high-sulfur coal reserves because of more stringent U.S. environmental regulation, industry analysts speculate that partnership with Rheinbraun will ease entry into the German coal import market. The German market in the coming years is expected to expand as subsidies are gradually withdrawn. Most German coal is presently subsidized at two to three times world prices, so even Consol's eastern coal,

${ }^{128}$ DuPont, 1992 Annual Report, p. 40. 
which is priced higher in the United States, could enter German markets profitably. ${ }^{129,130}$ Since most German hard coal-fired power plants are already equipped with flue gas desulfurization units, sulfur content probably will not be a significant obstacle.

Although DuPont retains a 50)-percent interest in Consol, it now reports its coal income as earnings from an unconsolidated affiliate on its FRS data submission. In 1991, DuPont's total sales from coal operations amounted to nearly $\$ 1.8$ billion. ${ }^{131}$ Thus, the elimination of Consol accounts for much of the difference in coal production indicators between 1991 and 1992 (Table 32). Cash derived from this sale may contribute some of the capital needed for its core business activities, such as DuPont's development of chlorofluorocarbon alternatives and revitalization of its dacron polyester business.

Occidental. During 1992, Occidental continued to follow its strategy to concentrate on its oil, natural gas and chemical businesses. As a result it decided to exit the coal business and reclassified its coal operations as a discontinued operation for purposes of financial reporting. The $\$ 622$-million loss from discontinued operations included an after-tax charge of $\$ 600$ million to provide for a write-down in the value of assets for anticipated liabilities associated with coal operations, and a loss of $\$ 22$ million from ongoing coal operations for $1992 .{ }^{132}$

Table 32. Coal Production Indicators for the FRS Companies, 1991-1992

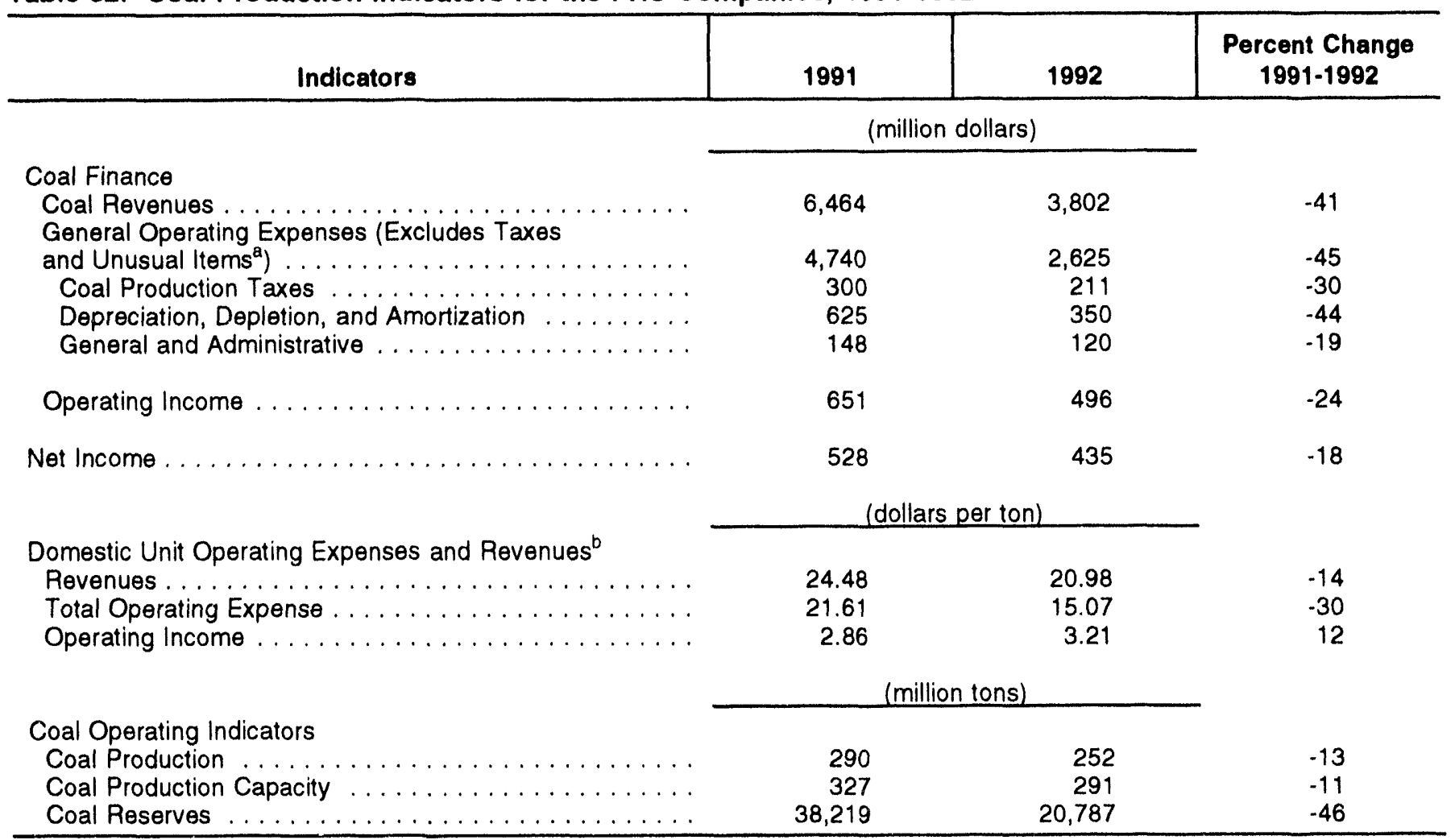

a Unusual items totaled $\$ 80$ million (pretax) in charges and $\$ 56$ million (after tax) in charges in 1991 , and $\$ 91$ million (pretax) in charges and $\$ 927$ million (after tax) in charges in 1992.

bExcludes unusual items and companies with foreign coal operations (Exxon and ARCO).

Sources: Energy Information Administration, Form EIA-28, and company annual reports for unusual items.

\footnotetext{
${ }^{129}$ Energy Information Administration, Annual Prospects for World Coal Trade 1989, DOE/EIA-0363(89) (Washington, DC, May 1989), pp. 36-37 and 47-48.

${ }^{130}$ See International Energy Agency (IEA), Energy Policies of IEA Countries - 1991 Review, (Paris, 1992), pp. 395-398. In 1991, the producer subsidy equivalent, as defined by the IEA, amounted to DM 180.5 per metric ton of coal produced.

${ }^{131}$ DuPont, DuPont Databook 1991, p. 4.

${ }^{132}$ Occidental Petroleum Corporation, 1992 Annual Report, p. 40.
} 
In mid-1993, Occidental completed the sale of its subsidiary, Island Creek Coal Corporation, to Consol. In 1991, Island Creek produced about 19 million tons of coal resulting in sales of $\$ 598$ million. ${ }^{133}$ When added to Consol's annual production of about 55 million tons, Island Creek is expected to strengthen Consol's competitive position as the second largest U.S. coal producer next to Hanson's subsidiary, Peabody Company. The financial consequences of this transaction were excluded from Table 32 because the sale was not concluded until 1993.

Sun. As part of a petroleum product strategy to concentrate on its more profitable areas, namely branded gasoline marketing, lubricants, chemicals and logistics, Sun agreed to sell its Western U.S. sub-bituminous steam coal operations for approximately $\$ 120$ million to RTZ Kennecott Corporation in 1992. ${ }^{134}$ Since the sale was completed in 1993, Sun reported coal production and income from discontinued operations in its 1992 FRS data submission, but neither operating revenue nor expenses. In 1992, Sun's production amounted to nearly 23 million tons. ${ }^{135}$

Shell. In 1992, Shell sold its U.S. mining operations to privately-owned Zeigler Coal Holding Company for cash and a 25-percent share in the equity of the purchaser. ${ }^{136}$ Since the sale was concluded at the end of 1992, Shell included production, operating income and expenses from its coal operations in its FRS data submission for 1992. In 1991, this amounted to about 24 million tons of production. ${ }^{137}$

Mobil. In 1991, following a strategy to sell assets that did not fit into its long-term strategy, Mobil exited the coal industry and reported a gain of $\$ 28$ million from the sale of its Wyoming coal mine. ${ }^{138}$ Since this sale was completed in 1991, no production, operating revenue or expenses were reported for coal operations in Mobil's 1992 FRS data submission, although ownership of 170 million tons of proved reserves were and remain for sale. In 1991, Mobil's coal production amounted to about 9 million tons yielding nearly $\$ 38$ million in revenue. ${ }^{139}$

Burlington Resources. In October 1992, Burlington, the largest private holder of coal reserves in the United States, sold nearly all of its coal properties to Great Northern Properties Limited Partnership, a private coal and timber company based in West Virginia. ${ }^{140,141}$ This included most of Burlington's 14 billion tons of coal reserves located in Montana, North Dakota, and Washington. Under the terms of the agreement, Burlington received $\$ 80$ million and will retain a production royalty on future sales from the more than 98 percent of the property that is presently unleased. In addition, Burlington held onto its Bull Mountain reserves in Montana, for which its subsidiary, Meridian Minerals Company, is seeking a permit to develop a mine with a projected annual capacity of 3 million tons.

Nerco. Although Nerco Coal Corporation was sold to RTZ Kennecott Company in April $1993,{ }^{142}$ it is included in the totals for 1992 FRS coal operations, because its parent company (Nerco, Inc.) has been added as a respondent to the FRS reporting program due to its growing oil interests. In 1992, Nerco produced less than 20 million tons of coal, down from 28 million for both 1990 and $1991 .^{143}$

\section{Financial and Operating Performance}

As a result of the above changes in investment, aggregate FRS companies' financial and operating results are considerably different for 1992, when compared to 1991 (Table 32). Coal revenues for worldwide FRS operations dropped $\$ 2.7$ billion dollars

\footnotetext{
${ }^{133}$ Occidental Petroleum Corporation, 1991 Annual Report Supplement, pp. 39-40.

${ }^{134}$ Sun Company, Inc., Form 10-K, December 1992, pp. 14-15.

${ }^{135}$ Sun Company, Inc., Form 10-K, December 1992, p. 10.

${ }^{136}$ Shell Oil Company, 1992 Annual Report, p. 11.

${ }^{137} 1993$ Ke'ystome Coal Industry Manual, p. 371.

${ }^{138}$ Mobil, Annual Report 1992, pp. 3 and 27.

${ }^{139}$ Mobil Corporation, 1992 Mobil lact Book, p. 76.

${ }^{140}$ See 1993 Keystone Coal Industry Manual, p. 379. According to this source, the U.S. Government was the largest holder of coal reserves with 155 billion short tons held. By comparison, Burlington held 14.6 billion short tons.

${ }^{141}$ The Billings Gazette, October 29, 1992, Section B, p. 1.

${ }^{12}$ Coal, April 1993, pp. 10-11.

${ }^{14}{ }^{3}$ Nerco, Inc., Form 10-K, December 1992, p. 37.
} 
or 41 percent. However, coal expenses dropped relatively more-by 45 percent, or $\$ 2.1$ billion. Production decreased 13 percent. This decrease is largely attributable to the absence of Consol's highercost Eastern U.S. coal production. Coal reserves held by FRS companies decreased 46 percent, for the most part due to Burlington's sale of its extensive reserves to a privately-held company. Excluding unusual items, net income from coal for FRS companies decreased 18 percent. Domestic unit operating income improved 12 percent, rising from $\$ 2.86$ per ton to $\$ 3.21$ per ton, primarily because of the underlying reduction in unit costs.

For a consistent set of FRS companies, 1992 production increased 7 percent from the 1991 level, although revenues and operating income fell (Table 33). Additions to property, plant, and equipment decreased by nearly 7 percent between the two years. In brief, aggregate FRS company reserves and output for 1993 will probably amount to less than half of the levels reported just one year earlier, representing a notable change in the FRS companies' investment pattern.

\section{Forelgn Interests}

Exxon and ARCO are the only FRS companies to continue to produce foreign coal. Exxon operates the giant Cerrejon coal mine in Colombia and has smaller interests in Australia and Canada. Exxon's foreign production was only 11 million metric tons in 1992. At only $\$ 10$ million, losses on all of its coal operations (domestic and foreign) in 1992 were considerably less than the $\$ 35$-million loss in 1990..$^{144}$ Some of this improvement is attributable to the closing of unprofitable underground operations at the Lemington mine in Australia and the sale of Exxon's 2-million-tona-year Byron Creek mine in Canada to Corbin Creek Resources, Ltd. in August 1992.

ARCO has extensive interests in Australian coal, mostly from large-scale surface mines producing high-quality coal. ARCO's Australian production was approximately 9 million tons in 1992, with 4 million tons of additional production expected from the developing Gordonstone mine in Queensland. ${ }^{145}$ Recently, ARCO's interests in developing coal resources in China took another step

Table 33. Financial Items in Coal for a Consistent Group of FRS Companies, 1991-1992

\begin{tabular}{|c|c|c|c|}
\hline Indicators & 1991 & 1992 & $\begin{array}{c}\text { Percent Change } \\
1991-1992\end{array}$ \\
\hline & \multicolumn{2}{|c|}{ (million dollars) } & \\
\hline \multicolumn{4}{|l|}{ Coal Finance } \\
\hline Revenues . . . . . . . . & 2,199 & 2,191 & -0.4 \\
\hline Operating Expenses ${ }^{b}$ & 1,898 & 1,894 & -0.2 \\
\hline Operating Income ${ }^{b}$ & 301 & 297 & -1.3 \\
\hline Net Income $e^{b} \ldots$ & 244 & 252 & 3.3 \\
\hline \multirow[t]{2}{*}{ Additions to Property, Plant, and Equipment. } & 256 & 239 & -6.6 \\
\hline & \multicolumn{2}{|c|}{ (million tons) } & \\
\hline \multicolumn{4}{|l|}{ Coal Operating Indicators } \\
\hline Coal Production $\ldots \ldots$ & 115 & 124 & 7.3 \\
\hline Coal Capacity .. & 139 & 137 & -1.2 \\
\hline Coal Reserves & 11,282 & 10,238 & -9.3 \\
\hline
\end{tabular}

${ }^{a}$ Data are for FRS coal producers reporting production and revenues in both 1991 and 1992. (Excludes companies with foreign coal operations.)

${ }^{b}$ Excludes unusual items.

Sources: Energy Information Administration, Form EIA-28 and company annual reports (for unusual items).

\footnotetext{
${ }^{144}$ Exxon Corporation, 1992 Annual Report, p. 19 and 1992 Annual Report Supplement, pp. 13 and 58-60.

${ }^{145}$ ARCO, 1992 Annual Report, pp. 22-23.
} 
forward with the announcement of a cooperation agreement between ARCO and China's Huaneng Coal Corporation to develop reserves in the ShenfuDongsheng coal field, and formation of ARCO Coal China, Inc. ${ }^{146}$ Although this is ARCO's first venture in coal operations in China, the firm already has oil and gas interests there.

\section{Alternative Energy}

Alternative energy is the FRS companies' smallest line of business and has been in most years the least profitable (Appendix B, Table B6). However, in 1992, the financial performance of alternative energy investments appeared to improve. Although revenues were hardly changed at $\$ 1.3$ billion (Table 34 ) between 1991 and 1992, operating income increased 20 percent while net income rose 53 percent (excluding unusual items). Much of the apparent improvement was due to the addition of Enron to the FRS group of companies in the 1992 reporting year. Excluding Enron, revenues were down 6-percent and operating income declined 22-percent. ${ }^{197}$

In 1992, the FRS companies' alternative energy investments consisted largely of tar sands operations and geothermal steam production. Investment in solar power manufacturing and cogeneration were of secondary importance. Sun and Exxon are largely responsible for FRS investment in Canadian synthetic crude oil production, while Unocal essentially accounts for the FRS companies' investment in geothermal production. Two companies, Coastal, and the recentlyadded Enron, account for a large share of FRS company investment in cogeneration facilities.

Exxon's and Sun's synthetic crude oil operations in Canadian tar sands represent the largest FRS company alternative energy investment. Lower prices for oil manufactured from tar sands reduced Sun's revenue and income from those crude oil operations in 1992.148 Exxon reported tar sands production of 45,000 barrels per day in 1992, while Sun reported a drop in production, due to a fire in its plant, ${ }^{149}$ from 61,000 barrels per day in 1991 to 59,000 barrels per day in 1992.

Table 34. Revenues, Income, and Investment in Other Energy for FRS Companies, 1991-1992

\begin{tabular}{|c|c|c|c|}
\hline Item & 1991 & 1992 & $\begin{array}{c}\text { Percent Change } \\
1991-1992\end{array}$ \\
\hline & \multicolumn{2}{|c|}{ (million dollars) } & \\
\hline \multicolumn{4}{|l|}{ Revenues and Expenses } \\
\hline Revenues $\ldots \ldots \ldots \ldots \ldots \ldots \ldots \ldots \ldots \ldots$ & 1,261 & 1,253 & -0.6 \\
\hline Operating Expenses $^{a} \ldots \ldots \ldots \ldots \ldots \ldots$ & 1,121 & 1,085 & -3.2 \\
\hline Operating Income $e^{a} \ldots \ldots \ldots \ldots \ldots \ldots \ldots$ & 140 & 168 & 20.0 \\
\hline 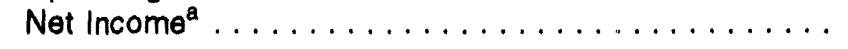 & 85 & 130 & 52.9 \\
\hline \multicolumn{4}{|l|}{ Net Investment in Place ${ }^{b}$} \\
\hline United States . . . . . . & 1,502 & 1,504 & 0.1 \\
\hline Foreign $\ldots \ldots \ldots \ldots \ldots \ldots \ldots \ldots \ldots \ldots \ldots \ldots \ldots \ldots \ldots$ & 1,438 & 1,306 & -9.2 \\
\hline Total $\ldots \ldots \ldots \ldots \ldots \ldots \ldots \ldots \ldots \ldots \ldots$ & 2,940 & 2,810 & -4.4 \\
\hline
\end{tabular}

${ }^{a}$ Excludes unusual items.

'Defined as the sum of net property, plant, and equipment and advances to unconsolidated subsidiaries.

Notes: Other energy includes nuclear fuel for all years.

Source: Energy Information Administration, Form ElA-28.

\footnotetext{
${ }^{146}$ See International Coal Report, August 20, 1993, pp. 10-11 and King's International Coal Trade, August 19, 1993, p. 13. ARCO first expressed interest in this venture in 1982 after inspecting Huaneng's mines. While this project looks promising (China already has domestic demand for over 1 billion tons of coal annually), it may take long to develop. Capital funds are needed not only for development of mining operations, but also for the development of related infrastructure, such as railroads and ports.

${ }^{147}$ Enron Corporation, 1992 Annual Report, p. 60.

${ }^{140}$ Sun Company, 1992 Annual Report, p. 54.

${ }^{149}$ Sun Company, 1992 Annual Report, p. 18., and Exxon Corporation, 1992 Supplement to Annual Report, p. 20.
} 
Unocal, the world's largest producer of geothermal power, has U.S. operations concentrated in California, and overseas operations in Indonesia and the Philippines. For 1992, Unocal reported both revenue and operating income that were unchanged from 1991, at $\$ 203$ million and $\$ 65$ million, respectively. ${ }^{150}$ In 1992, Unocal announced the planned sale of 3 geothermal power plants, with a combined capacity of 80 megawatts of geothermal capacity. Unocal also announced its intention to sell its geothermal properties in California's Imperial Valley, which accounts for 9 percent of its geothermal energy assets. ${ }^{151}$ Unocal's capital expenditures for geothermal operations rose to $\$ 37$ million in 1992 from $\$ 24$ million in 1991, in part due to expansion of its overseas operations. ${ }^{152}$

The addition of Enron to the ranks of the FRS companies added significantly to the FRS companies' involvement in cogeneration facilities in the United States and overseas. Cogeneration, which is the simultaneous production of steam and electricity from a single fuel source, is one of the largest growth markets for natural gas. In 1992, Enron acquired a 50percent interest in a cogeneration facility in Richmond, Virginia. In addition to Enron's cogeneration investments in the United States, Enron has 4 cogeneration plants in various stages of construction in Guatemala, the Philippines and the United Kingdom. ${ }^{153}$ Coastal is another major cogeneration investor, and is currently in the early stages of developing a gas-fired cogeneration plant in Gorzow, Poland, which is planned to have a capacity of 48 megawatts. ${ }^{154}$

Outside of tar sands, geothermal, and cogeneration, solar energy is the only remaining area of commercial alternative energy activity for the FRS companies. Because ARCO sold off its solar power manufacturing facility to Siemens in 1990, only Amoco and Mobil remain as FRS companies with solar power manufacturing facilities. ${ }^{155}$ However, neither Amoco nor Mobil publicly disclose financial data for their solar power subsidiaries. The U.S. Department of Energy announced in April 1992 that it would award $\$ 22$ million over the next three years to seven solar energy producers. Of the funds awarded, Solarex, Amoco's solar power subsidiary, will receive $\$ 5$ million, and Mobil Solar, will receive $\$ 4.1$ million. ${ }^{156}$

Chevron's sale of its uranium properties in New Mexico and Texas in 1991 marked the end of the FRS companies' involvement in uranium production. ${ }^{157}$ In 1992, Suncor, Sun's Canadian subsidiary, sold 4 million shares of the company's synthetic crude oil operations reducing the company's ownership share from 75percent to 68-percent. Sun also reported that it intends to further reduce its ownership interest in Suncor to 55 percent. ${ }^{158}$

\section{Research and Development}

The primary research and development (R\&D) efforts of the FRS companies in 1992 were in the areas of oil and gas recovery, chemical and petroleum refining processes, and petroleum and chemical product applications and development. In 1992, th FRS companies reported R\&D expenditures totaling $\$ 3.7$ billion, a decline of 6 percent from 1991 (Table 35). Although absolute R\&D expenditures have fluctuated from year to year, they have remained virtually constant as a percent of operating revenues.

FRS company research and development data includes data for DuPont, the owner of Conoco. DuPont's 1992 $R \& D$ expenditures accounted for a large percentage of total FRS company R\&D expenditures in that year. DuPont's primary business is chemical production or chemical-based manufacturing, rather than oil and gas production. In 1992, DuPont reported in their Securities and Exchange Commission Form 10-K that it spent $\$ 1.3$ billion on R\&D, primarily on chemicals. DuPont's relative $R \& D$ commitment plus its emphasis on nonenergy activities affects the distribution of total FRS company $R \& D$ expenditures.

\footnotetext{
${ }^{150}$ Unocal Corporation, 1992 Securities and Exchange Conımission Form 10-K, p. 50.

${ }^{151}$ Unocal Corporation, 1992 Securities and Exchange Commission Form 10-K, p. 12.

${ }^{152}$ Unocal Corporation, 1992 Securities and Exchange Commission Form 10-K, p. 51.

${ }^{153}$ Enron Corporation, 1992 Annual Report, p. 60.

${ }^{154}$ The Coastal Corporation, 1992 Securities and Exchange Commission Form 10-K, p. 22.

${ }^{155}$ The Wall Street Journal, March 27, 1991, p. A5.

156Inside Energy/with Federal Lands, April 27, 1992.

${ }^{157}$ American Nuclear Society, Nuclear News, July 1991, p. 82.

${ }^{158}$ Sun Company Incorporated, 1992 Annual Report, p. 17.
} 
Table 35. Worldwide Research and Development Expenciltures for FRS Companles, 1991-1992

\begin{tabular}{|c|c|c|c|}
\hline R\&D Applications & 1991 & 1992 & $\begin{array}{c}\text { Percent Change } \\
1991-1992\end{array}$ \\
\hline & \multicolumn{2}{|c|}{ (million dollars) } & \\
\hline \multicolumn{4}{|l|}{ Petroleum } \\
\hline Oil and Gas Recovery & 794 & 768 & -3.3 \\
\hline Other Petroleurn .... & 678 & 652 & -3.8 \\
\hline Total Petroleum & 1,472 & 1,420 & -3.5 \\
\hline Coal, Conventional ${ }^{\natural} \ldots \ldots$ & 17 & 14 & -75.0 \\
\hline Coal Gasification/Liquefaction ${ }^{\mathrm{a}}$ & 39 & 14 & -10.0 \\
\hline Other Energy ${ }^{b} \ldots \ldots \ldots \ldots \ldots$ & 95 & 80 & -15.8 \\
\hline Total Energy $\ldots \ldots \ldots \ldots \ldots \ldots \ldots \ldots \ldots \ldots \ldots$ & 1,623 & 1,514 & -6.7 \\
\hline Nonenergy $\ldots \ldots \ldots \ldots \ldots \ldots \ldots \ldots \ldots \ldots \ldots$ & 2,159 & 2,041 & -5.5 \\
\hline Unassigned .... & 120 & 117 & -2.5 \\
\hline Total $\ldots \ldots \ldots \ldots \ldots \ldots \ldots \ldots \ldots$ & 3,902 & 3,672 & -5.9 \\
\hline
\end{tabular}

${ }^{a}$ Conventional coal and coal gasification/liquefaction were combined in 1992 to avoid disclosure.

'Other Energy includes nuclear, oil shale, tar sands, solar, and geothermal.

Source: Energy Information A. .ministration, Form EIA-28.

As a chemical company, DuPont is representative of that industry in terms of its R\&D expenditures ( 3 to 4 percent of sales), whereas the oil and gas industry historically spends much less on $R \& D$ relative to sales ( 0.7 percent). The basic trends of FRS company aggregate R\&D data hold with or without DuPont in the calculation. However, with DuPont included, the nonenergy share of $R \& D$ expenditures gains as a percent of total R\&D expenditures at the expense of both petroleum and other energy, and the FRS companies R\&D-to-sales ratios are a little higher with DuPont included.
The decline in FRS company R\&D spending between 1991 and 1992 is attributable to R\&D cutbacks by more than half of the 20 companies who reportcd R\&D expenditures for 1992 . It reflects declining profits over the past two years in the FRS companies' petroleum operations and the resulting extensive restructuring the companies have undergone. The $\$ 230$-million decline is almost equally split between energy and nonenergy activities. The 75-percent decline in coal $R \& D$ is primarily attributable to a divestiture of coal operations by some of the FRS companies. 


\section{Appendix A \\ Structure of the Financial Reporting System - Form EIA-28}

\section{Reporting Format}

The FRS data system is designed to permit review of the functional performance of major energy-producing companies in total, as well as by specific functions and geographic areas of operation. The financial reporting schedules obtain data on revenues, cost, and profits, thereby indicating financial flows and performance characteristics. In addition, Form EIA- 28 collects balance sheet data (i.e., accumulated property, plant, and equipment, etc.), along with data on new investment in these accounts. To complement the financial data, a series of statistical schedules are included to trace physical activity patterns and to evaluate several physical/financial relationships.

In greater detail, the structure of the reporting package is as follows:

\section{Financial Reporting}

a. The starting point is the three basic financial statements required by the Securities and Exchange Commission (SEC) Form 10-K:

i. Consolidating Statement of Income (Schedule 5110)

ii. Selected Consolidating Financial Data (Balance Sheets) (Schedule 5120)

iii. Consolidated Statement of Cash Flows (Schedule 5131)

b. Corporate-wide financial information is first disaggregated by functional lines (segments) on Schedule 5110 and 5120 as follows:

i. Petroleum

ii. Coal

iii. Other Energy (includes Nuclear)

iv. Nonenergy (includes Chemicals) c. Nonenergy data is collected to describe corporate resource investment strategy and to allow aggregation of the FRS detailed schedules into the consolidated company amounts.

2. Operating and Statistical Information

a. For each type of energy activity, complementary operating information is obtained through the following schedules:

i. Petroleum (5211-5246)

ii. Coal (5341;

b. The schedules are designed to correspond to the financial information so that level of effort in the financial sense can be compared to physical results.

3. Complementary Schedules

a. Examine corporate research and development funding priorities (Schedule 5111)

b. Reveal impact of tax policy on financial results of reporting companies (Schedule 5112)

c. Monitor raw material acquisition and refined product disposition strategies of FRS companies (5211-5212)

d. Trace changes in reserves for petroleum (including natural gas) (5246) and coal (5341).

\section{Petroleum Segment Overview}

The petroleum line of business is further disaggregated into segments. ${ }^{159}$ These segments are presented as though each were a separate entity, with certain

\footnotetext{
${ }^{159}$ The other lines of business (Coal, Other Energy, and Nonenergy) were also disaggregated into segments but only through 1986.
} 
limitations, entering into transactions with other segments and third parties.

The following lists each segment within the petroleum line of business along with a brief description of that segment's principal revenue-generating product or service. (Further detail on the FRS petroleum segments may be found in the section on FRS Petroleum Supply and Trading Function and FRS Income Taxes.)

1. U.S. Production. Produces and sells U.S. crude oil, natural gas, and natural gas liquids. For FRS purpose sales of U.S. crude oil only can be made to the U.S. refining/marketing segment. Natural gas and natural gas liquids can be purchased from or sold directly to U.S./foreign third parties, unconsolidated affiliates, and other U.S./foreign segments.

2. U.S. Refining/Marketing. Purchases raw materials from the U.S. production segment, the foreign refining/marketing segment and third parties for refining or sale to third parties. The segment also purchases directly from the foreign production segment for those companies that do not have foreign refining/marketing and import all foreign production and purchases.

3. U.S. Pipelines. Transports crude oil, natural gas, and natural gas liquids through Federal or State regulated pipeline operations.

4. Foreign Production. Produces and sells foreign crude oil, natural gas, and natural gas liquids. Oil sales are made to the foreign refining/marketing segment unless the company does not have foreign refinery operations and imports all foreign oil production and purchases. Companies that meet these criteria may sell directly to the U.S. refining/marketing segment.

5. Foreign Refining/Marketing. Purchases raw materials from foreign production segments and U.S. refining/marketing segments, refines and sells to third parties, and refining/marketing segments.

6. International Marine. Provides marine transportation of foreign and U.S. source crude oil.

\section{Selection of FRS Reporting Companies}

Twenty-seven companies were initially notified of a requirement to file Form EIA-28. This group was initially chosen from the top 50 publicly-owned U.S. crude oil producers, in 1976, who had at least 1 percent of either the production or the reserves of oil, gas, coal, or uranium in the United States; or 1 percent of refining capacity or petroleum product sales in the United States. General Electric (GE) was originally included in the group, because of its interest in Pathfinder Mines Corporation (Pathfinder), which was a uraniumproducing company. However, GE did not file Form EIA- 28 because Pathfinders's financial statements were not consolidated into the financial statement of GE as a FRS reporting company. Pathfinder was not included in the FRS database.

Mergers, acquisitions and spinoffs together with the selection criteria applied to 1991 data resulted in the list of companies shown in the tabulation on the following page.

\section{Data Quality Assurance Program}

The data quality assurance program encompasses EIA's efforts to ensure the quality and integrity of FRS data. These efforts are evidenced in the design of the form and in the procedures applied to verify the data, i.e., the machine programmed checks and desk audit.

\section{Forms Design}

The Securities and Exchange Commission (SEC) Form $10-\mathrm{K}$ contains financial statements certified by independent certified public accountants. These financial statements, and the entire text of the annual report and Form 10-K, are reviewed by the SEC staff in order to provide the investing public with assurances that data filed on Form 10-K are accurate and are in accordance with generally accepted accounting principles and SEC Regulations.

In order to take advantage of the SEC review and the certification by certified public accountants, the FRS Form EIA-28 is designed in a multitier structure, which presents both the Form $10-\mathrm{K}$ figures and statistics and the more detailed data required by the FRS system. The top level FRS tier corresponds to Form $10-\mathrm{K}$; the second level tier is the first level disaggregated into the different sources of energy (e.g., petroleum, coal, etc.); and the third level tier is the second level disaggregated into the specific functional line-of-business segments within petroleum. (See the Petroleum Segment Overview section at the beginning of this appendix, which describes the FRS segments in detail.) The fourth level tier provides further detail within the individual 


\begin{tabular}{|c|c|c|c|c|c|c|c|c|c|}
\hline Company & $1977-81$ & 1982 & $1983-84$ & $1985-86$ & 1987 & 1988 & $1989-90$ & 1991 & 1992 \\
\hline Amerada Hess Corporation & $x$ & $x$ & $x$ & $x$ & $x$ & $x$ & $x$ & $x$ & $x$ \\
\hline American Petrofina Inc. & $x$ & $x$ & $x$ & $x$ & $x$ & $x$ & $x$ & & \\
\hline $\begin{array}{l}\text { Amoco Corporation } \\
\text { Anadarko Petroleum, Inc. }\end{array}$ & $x$ & $x$ & $x$ & $x$ & $x$ & $x$ & $x$ & $x$ & $\begin{array}{l}x \\
x\end{array}$ \\
\hline Ashland Oil, Inc. & $x$ & $x$ & $x$ & $x$ & $x$ & $x$ & $x$ & $x$ & $x$ \\
\hline Atlantic Richfield Co. (ARCO) & $x$ & $x$ & $x$ & $x$ & $x$ & $x$ & $x$ & $x$ & $x$ \\
\hline BP America, Inc. & & & & & $x$ & $x$ & $x$ & $x$ & $x$ \\
\hline Burlington Northem Inc. ${ }^{c}$ & $x$ & $x$ & $x$ & $x$ & $x$ & & & & \\
\hline Burlington Resources Inc. ${ }^{C}$ & & & & & & $x$ & $x$ & $x$ & $x$ \\
\hline Chevron Corporation ${ }^{d \theta}$ & $\underset{v}{x}$ & $\underset{v}{x}$ & $x$ & $x$ & $x$ & $x$ & $x$ & $x$ & $x$ \\
\hline $\begin{array}{l}\text { Cities Service } \\
\text { Coastal Corporation }\end{array}$ & $\begin{array}{l}x \\
x\end{array}$ & $x$ & & & & & & & \\
\hline $\begin{array}{l}\text { Coastal Corporation } \\
\text { Conoco }^{9}\end{array}$ & $\begin{array}{l}x \\
x\end{array}$ & $x$ & $x$ & $x$ & $x$ & $x$ & $x$ & $x$ & $x$ \\
\hline $\begin{array}{l}\text { E.I. du Pont de Nemours and Co. }{ }^{g} \\
\text { Enron Corporation }\end{array}$ & & $x$ & $x$ & $x$ & $\mathrm{x}$ & $x$ & $x$ & $x$ & $\begin{array}{l}x \\
x\end{array}$ \\
\hline $\begin{array}{l}\text { Exxon Corporation } \\
\text { Fina, Inc. }\end{array}$ & $x$ & $x$ & $x$ & $x$ & $x$ & $x$ & $x$ & $\begin{array}{l}x \\
x\end{array}$ & $\begin{array}{l}x \\
x\end{array}$ \\
\hline Getty Oil & $x$ & $x$ & $x$ & & & & & & \\
\hline Gulf Oil & $x$ & $x$ & $x$ & & & & & & \\
\hline Kerr-McGe日 Corporation & $x$ & $x$ & $x$ & $x$ & $x$ & $x$ & $x$ & $x$ & $x$ \\
\hline Marathon & $x$ & & & & & & & & \\
\hline $\begin{array}{l}\text { Mobil Corporation } \\
\text { Nerco, Inc. }\end{array}$ & $x$ & $x$ & $x$ & $x$ & $x$ & $x$ & $x$ & $x$ & $\begin{array}{l}x \\
x\end{array}$ \\
\hline Occidental Petroleum Corporation ${ }^{\dagger}$ & $x$ & $x$ & $\mathrm{x}$ & $x$ & $x$ & $\mathrm{x}$ & $x$ & $x$ & $\hat{x}$ \\
\hline Oryx Energy Company' & & & & & & $\ddot{x}$ & $x$ & $x$ & $x$ \\
\hline Phillips Petroleum Company & $x$ & $x$ & $x$ & $x$ & $x$ & $x$ & $x$ & $x$ & $x$ \\
\hline Shell Oil Company & $\ddot{x}$ & $\ddot{x}$ & $\ddot{x}$ & $x$ & $x$ & $x$ & $x$ & $x$ & $x$ \\
\hline Standard Oil Co. (Ohio) $(\mathrm{SOHIO})^{b}$ & $x$ & $x$ & $x$ & $x$ & & & & & \\
\hline Sun Company, Inc.! & $x$ & $x$ & $x$ & $x$ & $x$ & $x$ & $x$ & $x$ & $x$ \\
\hline Superior Oilk & $\mathrm{x}$ & $x$ & $x$ & & & & & & \\
\hline Tenneco Inc. ${ }^{m}$ & $x$ & $x$ & $x$ & $x$ & $x$ & $x$ & $\mathrm{x}$ & & \\
\hline $\begin{array}{l}\text { Texaco inc. } \\
\text { Total Petroleum (North America) Lid. }\end{array}$ & $x$ & $x$ & $x$ & $x$ & $x$ & $x$ & $\begin{array}{l}x \\
x\end{array}$ & $\begin{array}{l}x \\
x\end{array}$ & $x$ \\
\hline Union Pacific Corporation & $\mathrm{x}$ & $x$ & $x$ & $x$ & $x$ & $x$ & $\ddot{x}$ & $x$ & $x$ \\
\hline Unocal Corporation & $x$ & $x$ & $x$ & $x$ & $x$ & $\ddot{x}$ & $x$ & $x$ & $x$ \\
\hline USX Corporation & & $x$ & $x$ & $x$ & $x$ & $x$ & $x$ & $x$ & $\mathrm{x}$ \\
\hline
\end{tabular}

${ }^{a}$ Formerly Standard Oil Company (Indiana).

in 1987, BP America acquired all shares in Standard Oil Company (Ohio) that it did not already control.

'Burlington Resources was added to the FRS system and Burlington Northem was dropped for 1988. Data for Burlington Resources cover the full year 1988 even through that company was not created until May of that year.

${ }^{d}$ Formenly Standard Oil Sompany of Califomia.

${ }^{\circ}$ Chevron acquired Gulf Oil in 1984 but separate data for Gulf continued to be available for the full year 1984.

'Occidental acquired Cities Service in 1982 . Separate financial reports were available for 1982, so each company continued to be treated separately until 1983.

${ }^{9}$ Du Pont acquired Conoco in 1981. However, separate data for Conoco were available for 1981 and Du Pont was not included in the FRS system until 1982.

hAmerican Petrofina, Inc. changed its name to Fina, Inc. effective April 17, 1991.

'Texaco acquired Getty in 1984 but Getty was treated as a separate FRS company for that year.

U.S. Steel (now USX) acquired Marathon in 1982.

${ }^{k}$ Mobil acquired Superior in 1984 but both companies were treated separately for that year.

'Sun Company spun off Sun Exploration and Development Company (later renamed Oryx Energy Company) during 1988. Both companies are included in the FRS system for 1988 and some degree of double counting therefore exists for that year.

mTenneco sold its worldwide oil and gas assets and its refining and marketing assets in 1988. A number of other FRS companies purchased about 70 percent of Tenneco's assets.

"Effective June 1, 1991 Total's exploration, production and marketing operations conducted in Canada were spun off to Total Oil \& Gas, a new public entity.

" $X$ " indicates that the company was included in the FRS system for the year indicated.

Source: Energy Information Administration, Form ElA-28. 
segments, for example, the details of petroleum raw materials purchased and sold. Therefore, the lower level tiers can be aggregated to each successively higher tier until the consolidated Form 10-K figures are reached. In this way, the more detailed FRS data is tied to the more aggregated figures already reported publicly to the SEC and to individual company shareholders.

\section{Review Procedures}

Detailed machine editing and desk review procedures have been established for the incoming FRS data. The result of each review is the issuance of a letter to the reporting company containing questions regarding data elements. The reporting companies respond to each question, either by explaining the item or by amending any incorrect schedule. Amended schedules are reprocessed like the original with the full range of desk and machine checks. The result of this process is an internally consistent database which has been reconciled to the SEC Form 10-K, and from which the output reports can be compiled.

The FRS review procedures include:

- Machine programmed checks for mathematical accuracy (e.g., addition and subtraction);

- Machine programmed checks to insure that corresponding schedules are correctly crossreferenced;

- Desk reviews comparing reported FRS data to information from each company's Form 10-K and annual report;

- Desk reviews comparing reported data (e.g., average cost per foot drilled) for an individual FRS company to the average for all FRS reporting companies and to prior year information; and

- Desk reviews comparing reported data to other related data series to ascertain any unusual variance.

- Statistical disclosure avoidance procedures.

\section{Machine Programmed Checks}

There are 793 machine programmed checks for mathematical accuracy which ensure that each horizontal and vertical total equals the sum of the amounts within each line or column. There are also 49 machine programmed cross reference checks which ascertain that the amounts within a certain section of a schedule equal the amounts of the same description within a different schedule. The cross-reference checks are performed to ensure accuracy and consistency between different schedules. For example, the amount reported on Schedule 5210 for the U.S. production segment charges for depreciation, depletion and amortization is cross-referenced to ensure the same amount is reported on Schedule 5120 . Since the number and type of errors noted during these checks is an indicator of respondent understanding of the form, existing and potential problems are identified. The FRS review staff then can focus most of their attention on specific companies and areas where data accuracy may be more of a problem.

\section{Desk Review Procedures}

This is the detailed comparison of the data submitted to the FRS system to information contained in the Form $10-\mathrm{K}$ report and the annual report to shareholders as well as other publicly available information

As stated previously, the Form $10-\mathrm{K}$ report and the annual report contain financial information that has been examined and reported on by independent certified public accountants. This financial information along with textual and statistical information has also been reviewed by the SEC staff, which includes not only accountants, lawyers, and financial analysts, but also petroleum and mineral resource engineers. Hence, the data contained in these documents is considered a valuable reference in connection with the quality of FRS data.

The data contained in each respondent's submission is compared to the Form $10-\mathrm{K}$ and the annual report material using a detailed review program. Each review program step is performed by trained auditors supervised by CPA's with experience in auditing medium to large public companies.

These comparisons involve checking elements in both the financial and physical information areas (i.e., production, reserves, refinery statistics, etc.). Direct comparisons are made of specific data elements of the FRS form with corresponding items on Form 10-K or in the annual report. Indirect comparisons deal with information that is mentioned in Form $10-\mathrm{K}$ and the annual report but which is not quantified sufficiently for direct matching with FRS data. For example, if a respondent's annual report discussed an investment in coal, appropriate entries would be expected on the FRS schedule for coal. 
The FRS desk review procedures also include two other types of comparisons. The first type of comparison is made against prior year FRS data of the reporting company as well as current average data for all FRS reporting companies. These procedures assure consistency and reasonableness across reporting years.

The second type of desk review involves comparison to other related data series. Information contained in the FRS system is compared to data available from other DOE systems and published data, such as State mining surveys.

The FRS desk review procedures described above often lead to the issuance of a set of questions to the reporting companies each year. Response to these questions generates substantial interchange between the energy company staffs and the FRS staff. From this interchange the company personnel acquire a better understanding of the unique aspects of the FRS system, and the FRS staff learns more about each reporting company and the industry and how their accounting and reporting practices might affect the published FRS aggregate data.

\section{Statistical Disclosure Avoidance Procedures}

Procedures to prevent the disclosure of "individually identifiable energy information" have been applied to each table in this report. These tables provide summary, rather than company, level information. In most cases, the level of summarization is for all FRS companies. In certain cases, subcategories have been established that break the reports into size or other descriptive classes. Each table has been screened to ensure that no statistical disclosure will occur.

A large number of summary computer reports, generated from a single selected database, provide the basis for these tables. In conjunction with the summary reports, a parallel set of cell count reports were produced that tabulate for each report cell the number of nonzero values that were aggregated to produce the summary value. The cell count reports were then reviewed to identify whether potential disclosure problems would result from having an insufficient number of reporters or from having values that primarily represent dominant companies in a particular energy sector or activity.

If potential disclosure problems were identified, the tables were restructured to combine values or groups of individual cells in the tables so that the resultant tables were essentially disclosure free.

\section{Financial Analysis Guide}

\section{Indicators of Financial Performance}

To depict the activities of the FRS companies classified by the various energy industries, several indicators have been selected to show the amounts and geographic distribution of production, profits, cash generated, accumulated investment, and annual new investment. These indicators are compared across segments, across functions within segments, and geographically. They are the same, or similar, to indicators which have been in regular use by financial analysts and economists for many years. However, to avoid potential misunderstandings, a discussion follows of the measures used, their significance, and their limitations.

All of these measures are based upon the existing framework of financial reporting now used by industry, which relies on Generally Accepted Accounting Principles (GAAP). GAAP is the set of accounting principles by which industry reflects the financial results of operations, cash flows and financial position of individual business enterprises. The two primary problems one must contend with in using present GAAP-based data is that not all companies use the same GAAP accounting methods (e.g., full cost versus successful efforts in petroleum) and GAAP is based upon historical cost accounting principles (inflationary distortions and market values are not reflected). Both of these can cause a degree of noncomparability of reported data, across companies in the case of accounting methods, and through time in the case of historical cost accounting. In spite of these problems, the data are still regarded as meaningful, especially for trend analysis. (For a further discussion of these two problems see the Accounting Practices section of this appendix.)

The financial measure of the production and distribution of raw materials and refined products is operating revenues, or sales. Under GAAP this measure is based on arms-length transactions with third parties. However, in the FRS system the concept of sales has been extended to include sales from one segment to another. In such an approach, one segment's sales become another segment's costs, which must be eliminated in consolidation. The establishment of the FRS segments, the definition of sales (trading function), and the nontraceable and eliminations categories are discussed more fully in the Accounting Practices section of this appendix. 
Profits are the measure of financial return for company activities. In the FRS system, profits are expressed in terms of net income, operating income, and contribution to net income. The first term applies only to the consolidated company profits, and represents income after the provision for income tax expense. Operating income applies both to the segments and to the consolidated company and is the net of operating revenues and operating expenses. Excluded from this figure are such items as income taxes, and interest income and expense which are not allocated to the segments because they are "corporate level" items for FRS system purposes. (This is explained more fully in the Accounting Practices section of this appendix.) Contribution to net income is meant to be the equivalent of net income for individual segments. The term net income is not used for individual segment since several corporate level items are not allocated to the segment level.

"Cash flow from operations" is presented for the consolidated company and generally follows the indirect or reconciliation method of reporting cash flow from operations allowed by Statement of Financial Accounting Standards No. 95. The indirect method adjusts net income to remove the effects of changes during the year in receivables, payables, and inventory, and to adjust for the effects of depreciation, depletion, and amortization, gains or losses on disposition of property, plant, and equipment, and other items. "Cash flow from operations" represents the cash effects of producing and delivering the company's products and services. This presentation is useful in analyzing the ability to generate future positive cash flow, adequacy of cash flow in relation to current obligations, and the relationship of net income to cash flow.

Accumulated investment is expressed by (1) total assets, (2) net property, plant, and equipment (PP\&E), (3) investments and advances to unconsolidated affiliates, and (4) net investment in place.

Total assets is used in the context of the consolidated company figures, and is the total of the left-hand, or asset side, of the balance sheet.

Net PP\&E is frequently used as a measure of resources committed by an enterprise to an industry or segment. In the energy industry, net PP\&E accounts for the bulk of the consolidated assets.

Investments and advances to unconsolidated affiliates is of interest because many energy companies extend the range of their activities through subsidiaries which are less than 50-percent owned.
Finally, net investment in place is the total of: (1) net PP\&E and (2) investments and advances to unconsolidated affiliates.

Annual new investment is the measure of newly committed resources during any given year. In the FRS system, this is expressed in terms of: (1) additions to PP\&E; (2) current capitalized exploration and development (E\&D) expenditures; (3) current expenditures on E\&D; (4) additions to investment in unconsolidated affiliates; and (5) additions to net investment in place. The key words are: current, which means simply a current commitment of resources; and capitalized, which refers to expenditures which are classified as an addition to the PP\&E account in the balance sheet rather than as an expense of the current year in the income statement. Being capitalized indicates that the expenditure benefits future years and will be amortized to expense in the years benefitted. Being expensed means the benefit is to the current year and, therefore, the item should be shown as an expense of generating that year's revenues. The capitalization concept is at the heart of the difference between the successful efforts versus full cost accounting methods (discussed in the Accounting Practices section of this appendix.) Therefore, in the FRS system, total expenditures that are both expensed and capitalized are used as a measure of activity in order to standardize the measurement of resources invested.

\section{Reserve Interests (Foreign)}

This category includes all three categories of foreign reserves collected on the FRS form: (1) net ownership interest reserve; (2) proportionate interest in investee reserves and (3) foreign access reserves. These three foreign categories are added together for purposes of comparison with U.S. net working interest reserves because of the different nature of company interests in foreign production as compared to U.S. production.

Foreign petroleum reserve statistics are not strictly comparable to U.S. petroleum reserves because of the more complex and varying arrangements whereby companies obtain foreign crude oil. In addition, such arrangements have been known to be changed suddenly by those governments, thereby imposing a degree of uncertainty about what a reporting company can describe as their equity reserves. Foreign reserve statistics may be used as an indicator of the rate and magnitude of industry activity, but their different character from U.S. reserves must be recognized. 


\section{Accounting Practices}

\section{Relation of FRS to Generally Accepted Accounting Principles}

In completing the FRS form, with one exception noted below, companies use the same generally accepted accounting principles that they use in their financial statements filed with the SEC and in their annual reports to shareholders. Therefore, the amount and timing of income recognized and the capitalization policies will be the same, and net income in the FRS system will agree in total with that reported in each company's financial statements.

However, in the FRS system the presentation of the details of financial and statistical data will usually differ somewhat from that presented by most individual companies because current reporting standards do not require standardized business segments with standardized financial statement line items. In the FRS system, such standardization is necessary because of the need to aggregate a large number of companies (see Sec. 205(h), P.L. 95-91).

\section{FRS Petroleum Supply and Trading Function}

In establishing the FRS functional lines of business for reporting the activities of vertically integrated enterprises, it was necessary to define a set of trading rules. The rules define the activities which each segment can engage in. Otherwise, the segment data would be inconsistent across companies.

FRS defines the following segments within petroleum. (These segments are the main components of the 5200 series schedules.)

- U.S. Production

- U.S. Refining/Marketing

- U.S. Pipelines

- Foreign Production

- Foreign Refining/Marketing

- International Marine (Transportation).

A few of the more noteworthy rules, intended to make the trading activities of each FRS reporting company comparable to those of the other companies, are as follows:

1. Transfers (sales) between segments of the same company are recorded at arm's-length market prices. Where there are no comparable arm's-length transactions, field posted prices may be used. If third party realizations for specific raw material streams are below posted prices, the same lower prices should be used to value internal transfers of those raw materials.

2. All crude oil produced is recorded as a sale by the respective foreign or U.S. production segments to the corresponding foreign or U.S. refining/ marketing segments. The production segments are not permitted to sell crude oil directly to third parties but instead must transfer it to the company's refining/marketing segments which sells to the third parties. Companies that do not have foreign refining and import all foreign purchase may deviate from this practice and sell directly to U.S. refining/marketing.

3. Crude oil purchased from third parties is reflected as a purchase by the appropriate refining/ marketing segment: foreign refining/marketing for foreign source crude oil and U.S. refining/ marketing for U.S. source crude oil. Foreign source crude oil destined for a U.S. refining segment is then recorded as a sale by the foreign refining/ marketing segment to the U.S. refining/marketing segment.

4. Although production segments are neither sellers to, nor purchasers of, crude oil from third parties, by FRS system convention, natural gas may be both purchased and sold by production segments.

5. All transportation costs are incurred by the purchasing segment. Therefore, when U.S. refining/ marketing segments purchase crude oil from foreign refining/marketing segments, the U.S. refining/ marketing segment incurs the transportation cost.

6. With regard to sales to third parties, an export sale is a sale shipped free on board (f.o.b.) destination to a foreign location. In contrast, if a sale is made f.o.b. to a U.S. location, it is considered a U.S. sale even though the goods may ultimately be shipped overseas by a third party who purchased the goods.

7. A U.S. purchase is a purchase made from U.S. sources, even though in the case of goods purchased from third parties the materials purchased may be of foreign origin. In the FRS system the point of purchase and not the country of froduction is the determining factor. 


\section{Nontraceables and Eliminations}

One of the objectives of the FRS system is to allow economic and financial analysis of the energy industry to be performed by function. These functions, referred to in the FRS system as segments, are presented as separate entities with their own income statements. They reflect sales and purchases not only to and from unaffiliated parties, but also to and from other segments. Because the segments are not separate entities, but are part of an integrated firm, two special classifications are defined which allow reconciliation of consolidated company figures with those of the segments.

The first is the nontraceable classification, which covers those items included in the consolidated financial statements but not allocated to the segments. The second is the eliminations classification, which prevents double counting of intersegment transactions when the segments are consolidated into total company figures.

The nontraceable classification captures assets, liabilities, revenues, and expense items, which cannot be attributed to the activities of a egment. In the FRS data, this classifica:ion reflects general overhead for the consolidated firm and financial activities which represent corporate level activities.

While the financial transactions may play a key role in the firm's ability to do business, such transactions are not allocated to activities in an individual segment. The cash, corporate investments, interest income, and interest expense are examples of this. The accompanying example illustrates a nontraceable item, interest expense of $\$ 20$, and the $\$ 10$ corresponding tax effect (see "FRS Segment Tax Allocation Rules" in this appendix for further explanation).

The need for the eliminations classification arises when the product of one segment is sold to a second segment, which in turn sells the product again. In the accompanying example, $\$ 80$ of crude oil is sold by the U.S. production segment to the refining/marketing segment. The refining/marketing segment records $\$ 80$ of purchases of crude oil and, after processing, reflects sales of $\$ 160$ of refined product. If the segment figures were simply added to arrive at the consolidated total, the consolidated sales figure of $\$ 240(\$ 80+\$ 160)$ would be too high because of double counting. Thus, the eliminations classification subtracts $\$ 80$ of sales and $\$ 80$ of costs, leaving consolidated sales of $\$ 160$, the appropriate measure of the firm's consolidated transactions.

The nontraceables and eliminations classifications are treated as if they are segments for purposes of aggregating segment data to the consolidated level.

\section{FRS Income Taxes}

FRS Segment Tax Allocation Rules. In the FRS system, the tax allocated to each segment reflects a prorata share of consolidated income taxes. Where the consolidated company has income and pays a tax, but an individual segment has a loss, the segment with a loss reflects a tax benefit. This treatment is an FRS rule whose purpose is to reflect at the segment level the effect of the segment's operations on the consolidated income taxe's. The tax benefit reflected at the segment level is limited to the extent it offsets taxes in other segments on a consolidated basis.

\section{Example of Nontraceables and Eliminations}

\begin{tabular}{|c|c|c|c|c|c|}
\hline Financial Items & Consolidated & Elimination & Nontraceable & $\begin{array}{l}\text { Refining/ } \\
\text { Marketing }\end{array}$ & Production \\
\hline Revenues & 160 & (80) & - & 160 & 80 \\
\hline $\begin{array}{l}\text { Less Expenses: } \\
\text { General and }\end{array}$ & & & & & \\
\hline Administrative & 10 & - & 2 & 5 & 3 \\
\hline Other Operations & 10 & - & - & 5 & 5 \\
\hline Crude & - & $(80)$ & 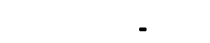 & 80 & - \\
\hline Operating Income & 140 & ? & (2) & 70 & 72 \\
\hline Less Interest Expense & 20 & - & 20 & - & - \\
\hline Less Income Taxes & 60 & - & (11) & 35 & 36 \\
\hline Net Income & 60 & - & (11) & 35 & 36 \\
\hline
\end{tabular}

Note: Numbers in parentheses are negative. 
In comparing an FRS company's segment to a specialized (nonintegrated) company in the same line of business, one must keep the above described rule in mind. The tax effect may be different, for a specialized company cannot report tax benefits for operating losses in the same year. It must carry the loss forward, or backward, against profits of other years, while a segment of an otherwise profitable consolidated firm can show a tax benefit by FRS conventions since a segment's loss can offset profits in other segments on a consolidated basis.

FRS Reporting Companies, Segments, and Tax Paying Entities. This section explains how FRS reporting companies and their segments differ from the entities which actually pay income taxes. The FRS system reports energy activities on a consolidated company basis, disaggregated into various energy lines of business. Accordingly, income tax expense, current and deferred, is reflected on a line-of-business basis. However, under the tax laws, taxes are not necessarily based upon FRS reporting company consolidated earnings of the FRS line-of-business segments.

The tax-paying entities of an FRS reporting company are its subsidiaries. Sorne are incorporated in the United States and some in foreign countries, and each may operate in the United States, foreign countries, or both. Income tax expense in the FRS system consists of both U.S. and foreign income taxes incurred by these subsidiaries. Taxes reflected by the consolidated company and each individual segment are allocated from taxes paid and deferred by the actual tax-paying entities.

Under U.S. tax law, U.S. income taxes are not required to be paid by foreign corporations on their foreign operations. Only earnings of foreign corporations earned in the United States or paid into the United States as dividends to the U.S. parent corporation (owner) are taxed by the United States. Foreign and U.S. earnings of U.S. corporations, including divisions and branch operations, are taxed by the United States. All income subject to U.S. tax, whether the entity is a foreign or U.S. corporation, is given the benefit of the foreign income tax credit (up to the statutory rate) to avoid double taxation. Each U.S. incorporated subsidiary of a U.S. corporation elects either to be included in a consolidated U.S. tax return or to file a separate return, depending on which election is most likely to minimize the aggregate U.S. and foreign taxes. The main point to be made here is that corporate organization and relationships are not purely a function of line-of-business financial reporting. This fact requires that allocations be made of taxes incurred so that they can be classified according to the FRS segment format. These allocations are required when a subsidiary is involved in both U.S. and foreign operations and/or in more that one line of energy business. For example, the FRS system has separate segments for the foreign and U.S. petroleum production business, as it also does for the foreign and U.S. refining/marketing business. Therefore, if an FRS reporting company has a foreign subsidiary involved in both petroleum production and refining/marketing of petroleum, a disaggregation of that subsidiary's activities, including income taxes, must be performed.

The disaggregation is further complicated by the existence of nontraceable items such as interest expense, which is quite large for most companies. In making the tax allocation, the nontraceable column must be treated as a separate segment. Therefore, the nontraceable columns should generate U.S. and foreign income tax benefits.

\section{Deferred Taxes}

The Financial Accounting Standards Board (FASB) began working on a project to reexamine the generally accepted accounting procedure for income taxes in September, 1982. Accounting Principles Board Opinion 11 ("APB 11"), issued in 1967, was the current standard for income taxes but faced criticism and concerns about the inconsistencies in its amendments and interpretations. In addition, problems created by new tax depreciation methods and changes in accounting for income taxes in other countries were making APB 11 outdated. In 1988, the FASB issued Statement of Financial Accounting Standards No. 96 "Accounting for Income Taxes" ("SFAS 96") to address the increased complexity and significance of deferred taxes in the balance sheet. However, because of its complex scheduling process and stringent tax asset provisions, SFAS 96 soon became a source of controversy among businesses, CPA firms, professional organizations, and industry trade groups. In response to the criticism, the FASB deferred the required implementation date of SFAS 96 three times (in SFAS 100,103, and 108), and set about developing a new standard which would not only address criticism of APB Opinion 11 but also the controversy surrounding SFAS 96. The result was SFAS 109, "Accounting for Income Taxes." Effective for periods beginning after December 15, 1992, SFAS 106 will supersede SFAS 96.

The objective of accounting for income taxes is the recognition and presentation in the financial statements of: 
- taxes currently payable or refundable, and

- deferred tax assets and liabilities for the future tax consequences of events that have been recognized in the financial statements or tax returns.

Deferred taxes reflect the future tax consequences of events already recognized in either the financial statements or tax returns or that result from enacted changes in tax laws or rates. SFAS 109 uses the balance sheet approach, also referred to as the liability method, to determine deferred taxes. This method, which was first introduced in SFAS 96, differs from APB 11, which used the income statement approach. SFAS 109 also requires a deferred tax asset to be recognized for deductible temporary differences and operating loss and tax credit carryforwards using the applicable tax rate.

In general, the income statement approach recognizes deferred taxes on the temporary timing differences between the pretax accounting income and taxable income each year. Temporary timing differences are those differences between accounting and taxable income which will ultimately reverse. For example, intangible drilling costs for a successful well is expensed when paid for tax purposes, but capitalized and depreciated for accounting purposes. If we assume intangible drilling costs of $\$ 100,000$ on one well was the only timing difference, and this cost was depreciated $\$ 20,000$ per year for accounting purposes, there would be an $\$ 80,000$ temporary timing difference in year one, as taxable income would be less than accounting income. This timing difference would reverse $\$ 20,000$ each year as the intangible drilling cost is depreciated for accounting purposes with no deduction for tax purposes. At the end of the fifth year, the timing difference would be completely reversed.

The liability approach recognizes deferred taxes on the temporary differences between the financial and tax bases of assets and liabilities. Both the deferred tax liability and the deferred tax asset must be measured using the applicable tax rate. The applicable tax rate is the enacted tax rate to be applied to the last dollar of taxable income for the year when the liability is expected to be settled or the assets recovered. A single flat tax rate may be used for companies for which graduated rates are not a significant factor. A deferred tax asset is recognized for existing alternative minimum tax credit carryforwards for tax purposes. When computing deferred tax assets and/or liabilities, if there is a change in the tax rate or tax law, the deferred tax assets and/or liabilities should be adjusted in the period that includes the enactment date. To the extent deferred tax balances are adjusted for the effects of such changes, income tax expense or benefit from continuing operations is charged or credited. Using the example from the preceding paragraph, the financial statement basis of the intangible drilling cost in year one would be $\$ 80,000$ ( $\$ 100,000$ less $\$ 20,000$ depreciation), while there would be no basis for tax purposes as the costs were totally deducted. Deferred taxes would be provided for the $\$ 80,000$ difference using enacted tax rates. Deferred taxes would be adjusted each year until the difference between the accounting and tax basis was fully eliminated at the end of year five.

Once deferred tax assets and liabilities relating to the future tax consequences of temporary differences and carryforwards have been measured, the deferred tax provision or benefit is based on the net change in a deferred tax balance during the year. The income tax expense or benefit for the period is derived from the total tax currently payable or refundable and the deferred tax expense or benefit.

As stated earlier, the effective date for implementation of SFAS 109 is for fiscal years beginning after December 15, 1992. There are two transition options available when adopting SFAS 109, prospective or retroactive application. A company may elect to restate the financial statements for any number of consecutive prior years (retroactive application) or may report a cumulative effect adjustment below "income from continuing operations" (prospective application).

As of December 31, 1992, seventeen FRS reporting companies had adopted the provisions of SFAS 109, which resulted in a net $\$ 163$ million benefit to their 1992 reported earnings. The remaining nine FRS reporting companies will be required to adopt in the first quarter of 1993, and they have estimated its effect will result in a $\$ 600$ million benefit to 1993 reported earnings. Of the nine companies not currently reporting under SFAS 109, five report under APB 11 and three report in accordance with SFAS 96.

\section{Corporate Acquisitions}

Under FRS reporting rules, no acquisitions are accounted for under the pooling of interest method. This is because under the pooling method, the financial statements do not reflect such transactions as new investment, since the historical financial statements are restated. One of the objectives of the FRS is to track new investment activities.

For FRS reporting purposes, acquisitions accounted for as pooling for annual report purposes must be reflected 
in the FRS filing under a modified purchase method. All purchase accounting rules are followed, except that the assets of the acquired company are not revalued, but are recorded at their book values as stated on the acquired company's books.

\section{Full Cost and Successful Efforts Accounting Methods}

FRS reporting companies are permitted to choose between two accounting methods "full cost" and "successful efforts" to account for their exploration and production activities. Twenty-three of the twenty-five FRS companies use the successful efforts method. The main difference between the two methods is the treatment of dry exploratory well cost.

Under full cost, the cost of a dry exploratory well is capitalized and then amortized to the income statement over the production life of successful wells. Thus, the costs of both dry and successful wells are capitalized and reflected in the balance sheet as part of producing properties.

Under successful efforts, the cost of a dry exploratory well is written off to expense in the year drilling is determined to be unsuccessful. There is no capitalized cost of such dry exploratory wells carried on the balance sheet.

In comparison to the successful efforts method, the full cost method will: (1) show less volatility of earnings, since the cost of unsuccessful wells is amortized over many years; (2) show a higher balance in accumulated property, plant, and equipment (PP\&E), since the account contains the costs of all wells drilled, including dry exploratory wells; (3) usually show higher earnings during years of intense exploratory activity when a number of dry wells are encountered; and (4) show the same cumulative earnings over a long period of years, since eventually all costs will be amortized to the income statement. These effects are minimized if the firm is large, since the exploratory activities of a large firm are usually smaller relative to total production operations than they are in a small production firm.

Usually one cannot determine the precise effect of using one method over the nther. However, one large firm switched from full cost to successful efforts in 1975 and restated 1973 and 1974 data to the successful efforts method. Thus, we have available the impact of this conversion on their comparative net income, net PP\&E, and return on net PP\&E for 1973 and 1974 (see text table).

Since twenty-three of the FRS companies presently use successful efforts accounting, comparability problems are inconsequential.

\section{Inventory Accounting-LIFO Versus FIFO}

The Last In-First Out (LIFO) and the First In-Last Out (FIFO) inventory methods are most often used in the preparation of the financial statements of industrial enterprises.

Under FIFO, the balance sheet valuation of inventory is based upon the most recent prices paid for the physical units on hand at year's end, and the income statement reflects the cost of units sold at the oldest unit cost. In periods of rapidly rising prices, the income statement

\section{A Comparison between Full Cost and Successful Efforts Accounting Methods}
Years
Full Cost
Successful Efforts

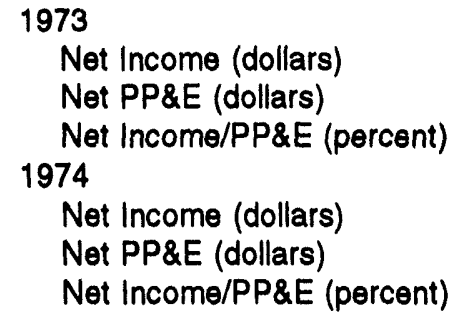

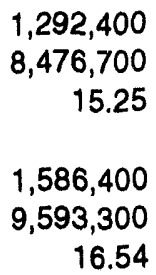

$1,243,300$

$7,511,300$

16.70

$1,544,700$

$8,563,500$

17.98

Source: Texaco, Inc., 1974 and 1977 Annual Report and Statistical Supplements. 
reflects higher profits than would be reflected if the units sold were priced at current replacement cost or under the LIFO method.

Under LIFO, the balance sheet valuation of inventory is based on the prices paid for the first units of each major type of inventory ever purchased. For example, crude oil could be carried at $\$ 10$ per barrel, which of course vastly understates the value of the inventory in terms of its replacement cost. The income statement reflects the cost of units sold at the most recent prices paid for the number of units sold. Thus, cost of goods sold reflects nearly a replacement cost amount, and profits are lower than under the FIFO method.

Since either method is permitted under the Federal tax laws, most companies use LIFO for operations subject to U.S. taxation because earnings and hence taxes are lower under this method. By 1979, most FRS reporting companies were primarily using the LIFO inventory method. Most analysts probably would agree that LIFO is the preferable method, since the income statement is more realistic than with FIFO. However, its disadvantage is that the balance sheet's inventory figure is understated, and hence the stockholder's equity amount is correspondingly understated.

In 1992, five FRS companies reported liquidation profits or losses, compared to 4 in both 1991 and 1990. The 1992 aggregate liquidation profits increased the reporting companies' operating income by $\$ 7$ million, which represented 0.1 percent of their aggregate operating income. This compares to a $\$(0) .1$ billion increase in both 1991 and 1990 which represented 0.5 percent of their respective aggregate operating income for those years.

\section{Forelgn Currency Translations}

In December 1981, the Financial Accounting Standards Board (FASB) issued Statement No. 52, "Foreign Currency Translations," which superseded FASB-8, "Accounting for the Translation of Foreign Currency Transactions and Foreign Currency Financial Statements." FASB-52 covers the translation of the foreign currency financial statements for the purposes of the consolidation, combination, or reporting by the equity method, and the translation of foreign currency transactions. The new statement required that assets, liabilities, and operations of an entity be stated in the currency of the primary economic environment in which the entity operates (termed, the "functional currency"). If a foreign entity has not kept its financial records in the functional currency, remeasurement is required prior to translation. Any gain or loss on remeasurement is recognized in current net income. The assets and liabilities of the foreign entity are translated from its functional currency to the reporting currency at the current rate of exchange.

Under FASB-52, gain or loss on the translation of foreign currency financial statements is shown as a separate component of stockholders' equity, whereas, under FASB-8, all non-monetary balance sheet items were translated at the historical rate of exchange. Thus, the change to FASB-52, which uses the current rate of exchange, had the most significant impact on inventories and fixed assets. With respect to the income statement, FASB-52 requires that only gains or losses from foreign currency transactions be included.

As the text table on the following page indicates, foreign currency translation losses decreased stockholders' equity by 2.1 percent in 1992, while foreign currency transaction gains increased pretax income by 1.7 percent.

\section{FRS Database History}

The Form EIA-28, Financial Reporting System (FRS), database has existed in three formats during its 18-year history (In addition, there have been minor, periodic adjustments since 1987 . The only one worth noting is the change from a Statement of Sources and Uses of Funds to a Statement of Cash Flows, effective in the 1986 reporting year). The first version of the Form EIA-28 and its database covered years 1974-1980. The second version covered years 1981-1986. The third and current version began with the 1987 reporting year and is approved through the 1992 reporting year.

The first full reporting year for the first version of the form was 1977. It consisted of 47 separate schedules containing 8,775 data elements, and was 136 pages long. ${ }^{160}$ This version of the database contained a significant amount of detail at the consolidated level, at each line of business, and in the breadth of operating statistics. However, not all of the data collected was loaded into the database. About 1,000 elements were not unique to individual companies-such as joint venture information-and were maintained only in their hard copy format.

\footnotetext{
${ }^{160}$ In order to extend the range of data back through 1974, an abbreviated version of the form was collected for the years 1974 through 1976. Almost 2,900 data elements (one-third of the total) were collected for each of these years, and consisted primarily of summary data from 26 of the 47 schedules.
} 
The Impact of FASB-62, Forelgn Currency Translations, on Stockholders' Equily and Pretax Income, 1982-1992

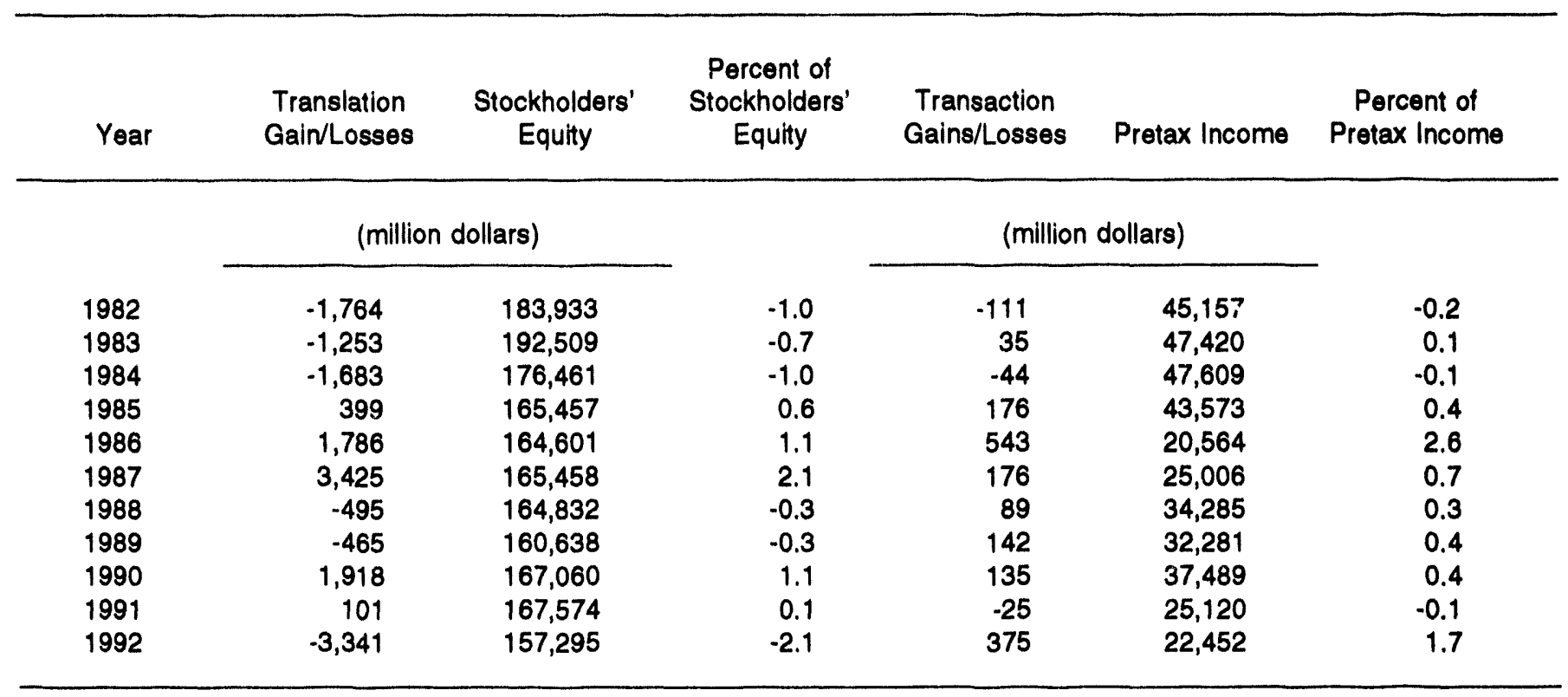

In 1982 (for the 1981 reporting year) the form was shortened by 72 percent, to 2,468 elements. The format was still the same, with data collected at the consolidated level, four energy lines of business (petroleum, coal, nuclear, and other energy), and nonenergy. The 1981-1986 form consisted of 19 schedules, and was 35 pages long. Although data was still collected by each line of business, most of the decline was at the line of business level, where more than 81 percent of the form was eliminated compared to a 58-percent decline at the consolidated level.
In 1988 (for the 1987 reporting year) the form was shortened by another 33 percent, to 1,650 elements. The consolidated level was shortened by 32 percent, primarily by combining other energy with nuclear energy. Petroleum data declined by 10 percent, coal by 74 percent, and separate income statement schedules for the remaining lines of business (coal, nuclear and other energy, and nonenergy) were eliminated altogether (although income statements for each of these lines of business were incorporated into Schedule 5110, Consolidating Statement of Income). The form currently has 14 schedules, and is 27 pages long. 


\section{Appendix B}

\section{Detailed Statistical Tables}

Table B1. Selected U.S. Operating Statistics for FRS Companies and U.S. Industry, 1991 and 1992

\begin{tabular}{|c|c|c|c|c|c|c|c|c|}
\hline \multirow{2}{*}{ Operating Statietics } & \multicolumn{3}{|c|}{ FRS Companies } & \multicolumn{3}{|c|}{ U.S. Induatry 1} & \multicolumn{2}{|c|}{$\begin{array}{l}\text { FAS as a Percent } \\
\text { of U.S. Industry }\end{array}$} \\
\hline & 1991 & 1992 & $\begin{array}{l}\text { Percent } \\
\text { Change }\end{array}$ & 1991 & 1992 & $\begin{array}{l}\text { Percent } \\
\text { Change }\end{array}$ & 1991 & 1992 \\
\hline \multicolumn{9}{|l|}{$\begin{array}{l}\text { Petroleum } \\
\text { Net Production }\end{array}$} \\
\hline $\begin{array}{l}\text { (million barrels) } \\
\text { Natural Gas }\end{array}$ & $1,818.1$ & $1,750.2$ & -3.7 & $3,266.0$ & $3,219.0$ & -1.4 & 55.7 & 54.4 \\
\hline $\begin{array}{l}\text { (billion cubic foet) } \\
\text { Net Imports }\end{array}$ & $7,509.5$ & $7,877.7$ & 4.9 & $17,202.0$ & $17,423.0$ & 1.3 & 43.7 & 45.2 \\
\hline $\begin{array}{l}\text { Crude Oil and Natural Gas Liquids } \\
\text { (million barrels) } \\
\text { Refinery Capacity }\end{array}$ & 917.9 & 868.8 & -5.4 & $2,243.7$ & $2,383.0$ & 6.2 & 40.9 & 36.5 \\
\hline $\begin{array}{l}\text { (thousand barrels per day) } \\
\text { Refinery Output } 2\end{array}$ & $11,203.0$ & $10,952.0$ & -2.2 & $16,452.6$ & $15,804.4$ & -3.9 & 68.1 & 69.3 \\
\hline 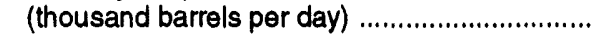 & $11,122.0$ & $10,994.0$ & -1.2 & & $15,932.0$ & 0.4 & 70.1 & 69.0 \\
\hline $\begin{array}{l}\text { Bituminous Coal and Lignite Production } \\
\text { (million tons) }\end{array}$ & 289.6 & 251.9 & -13.0 & & 997.5 & 0.2 & 29.1 & 25.3 \\
\hline
\end{tabular}

1 U.S. area defined to include the 50 States, District of Columbia, U.S. Virgin Islands, and Puerto Rico.

2 For FRS companies, includes refinery output at own refineries for own account and at others' refineries for own account.

Note: The data for total U.S. production of crude oil and natural gas liquids and natural gas (dry) utilized in this report are taken from Energy Information Administration, Form ElA-23, see U.S. Crude Oil, Natural Gas, and Natural Gas Liquids Reserves 1992 Annual Report (October 1993). This source is utilized in order to preserve consistency between production reported in the context of oil and gas reserves and reserve additions and production reported elsewhere in this report. However, the official Energy Information Administration U.S. totals for crude oil and natural gas plant production are 3,292.5 million barrels in 1992 and 3,346.3 million barrels in 1991 (see Energy Information Administration, Petroleum Supply Annual 1992, Volume 1 (May 1993), p. 2). For dry natural . .s production, the official Energy Information Administration U.S. totals are 17,775 billion cubic feet in 1992 and 17,751 billion cubic feet in 1991 (see Energy information Administration, Natural Gas Monthly, September 1993, p. 3).

Sources: Industry data - Petroleum net production: Energy Information Administration, Form ElA-23, see U.S. Crude Oil, Natural Gas, and Natural Gas Liquids Resenes, 1992 Annual Report (October 1993). Net imports: data compiled for the Intemational Energy Agency by the Petroleum Supply Division, Office of Oil and Gas, Energy Information Administration. Refinery capacity and refinery output: Energy Information Administration, Forms EIA-820 and EIA-810, see Petroleum Supply Annual, 1991 and 1992. Coal production: Energy Information Administration, Form EIA-7A, seo Coal Production 1992, (October 1993). 
Table B2. Selected U.S. Operating Statistics for FRS Companies and U.S. Industry, 1986-1992

\begin{tabular}{|c|c|c|c|c|c|c|c|}
\hline Operating Statlotice & 1886 & 1987 & 1888 & 1989 & 1990 & 1991 & 1992 \\
\hline \multicolumn{8}{|l|}{$\begin{array}{l}\text { Petroloum } \\
\text { Net Production } \\
\text { Crude Oil and Natural Gas Liquids } \\
\text { (million barrels) }\end{array}$} \\
\hline 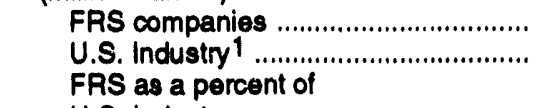 & $\begin{array}{l}2,089.6 \\
3,711,0\end{array}$ & $\begin{array}{l}2,069.5 \\
3,620.0\end{array}$ & $\begin{array}{l}2,102.1 \\
3,565.0\end{array}$ & $\begin{array}{l}1,911.1 \\
3,317.0\end{array}$ & $\begin{array}{l}1,814.0 \\
3,237.0\end{array}$ & $\begin{array}{l}1,818.1 \\
3,266.0\end{array}$ & $\begin{array}{l}1,750.2 \\
3,219.0\end{array}$ \\
\hline $\begin{array}{l}\text { U.S. Industry } \\
\text { Natural Gas } \\
\text { (billion cubic feet) }\end{array}$ & 56.3 & 57.2 & 59.0 & 57.6 & 56.0 & 55.7 & 54.4 \\
\hline $\begin{array}{l}\text { FRS companies } \\
\text { U.S. Industry }{ }^{1} \ldots \ldots \ldots \ldots \ldots \ldots \ldots \ldots \ldots \ldots \ldots \ldots \\
\text { FRS as a percent of }\end{array}$ & $\begin{array}{r}7,143.6 \\
15,610.0\end{array}$ & $\begin{array}{r}7,214.1 \\
16,114.0\end{array}$ & $\begin{array}{r}7,627.3 \\
16,670.0\end{array}$ & $\begin{array}{r}7,480.7 \\
16,983.0\end{array}$ & $\begin{array}{r}7,578.2 \\
17,233.0\end{array}$ & $\begin{array}{r}7,509.5 \\
17,202.0\end{array}$ & $\begin{array}{r}7,877.7 \\
17,423.0\end{array}$ \\
\hline $\begin{array}{l}\text { U.S. Industry .................................. } \\
\text { Net Imports } \\
\text { Crude Oil and Natural Gas Liquids } \\
\text { (million barrels) }\end{array}$ & 45.8 & 44.8 & 45.8 & 44.0 & 44.0 & 43.7 & 45.2 \\
\hline 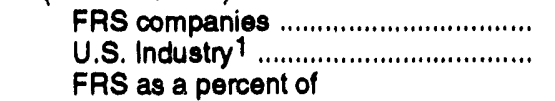 & $\begin{array}{r}871.3 \\
1,697.7\end{array}$ & $\begin{array}{r}898.9 \\
1,877.7\end{array}$ & $\begin{array}{r}906.4 \\
2,003.0\end{array}$ & $\begin{array}{r}834.3 \\
2,289.3\end{array}$ & $\begin{array}{r}975.2 \\
2,324.7\end{array}$ & $\begin{array}{r}917.9 \\
2,243.7\end{array}$ & $\begin{array}{r}868.8 \\
2,383.0\end{array}$ \\
\hline $\begin{array}{l}\text { U.S. Industry } \\
\text { Refinery Capacity } \\
\text { (thousand barrels per day) }\end{array}$ & 51.3 & 47.9 & 45.3 & 36.4 & 41.9 & 40.9 & 36.5 \\
\hline $\begin{array}{l}\text { FRS companies } \\
\text { U.S. Industry }{ }^{1} \ldots \ldots \ldots \ldots \ldots \ldots \ldots \ldots \ldots \ldots \ldots \ldots \ldots \\
\text { FRS as a percent of }\end{array}$ & $\begin{array}{l}12,526.0 \\
16,234.0\end{array}$ & $\begin{array}{l}12,462.0 \\
16,581.0\end{array}$ & $\begin{array}{l}12,281.0 \\
16,285.0\end{array}$ & $\begin{array}{l}11,489.0 \\
16,238.0\end{array}$ & $\begin{array}{l}11,372.0 \\
16,430.4\end{array}$ & $\begin{array}{l}11,203.0 \\
16,452.6\end{array}$ & $\begin{array}{l}10,952.0 \\
15,804.4\end{array}$ \\
\hline $\begin{array}{l}\text { U.S. Industry } \\
\text { Refinery Output } \\
\text { (thousand barrels per day) }\end{array}$ & 77.2 & 75.2 & 75.4 & 70.8 & 69.2 & 68.1 & 69.3 \\
\hline $\begin{array}{l}\text { FRS companies } \\
\text { U.S. Industry }{ }^{1} \\
\text { FRS as a percent of }\end{array}$ & $\begin{array}{l}11,459.0 \\
14,927.0\end{array}$ & $\begin{array}{l}11,712.0 \\
15,085.0\end{array}$ & $\begin{array}{l}12,033.0 \\
15,426.0\end{array}$ & $\begin{array}{l}11,413.0 \\
15,654.6\end{array}$ & $\begin{array}{l}11,312.0 \\
15,911.2\end{array}$ & $\begin{array}{l}11,122.0 \\
15,872.2\end{array}$ & $\begin{array}{l}10,994.0 \\
15,932.0\end{array}$ \\
\hline 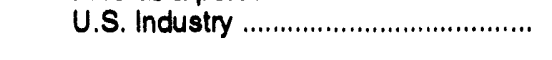 & 76.8 & 77.6 & 78.0 & 72.9 & 71.1 & 70.1 & 69.0 \\
\hline \multicolumn{8}{|l|}{$\begin{array}{l}\text { Bltuminous Coal and Lignito } \\
\text { Production } \\
\text { (million tons) }\end{array}$} \\
\hline $\begin{array}{l}\text { FRS companies } \\
\text { U.S. Industry }{ }^{1} \ldots \ldots \ldots \ldots \ldots \ldots \ldots \ldots \ldots \\
\text { FRS as a percent of }\end{array}$ & $\begin{array}{l}227.6 \\
886.0\end{array}$ & $\begin{array}{l}255.3 \\
915.2\end{array}$ & $\begin{array}{l}285.3 \\
950.3\end{array}$ & $\begin{array}{l}286.9 \\
980.7\end{array}$ & $\begin{array}{r}282.0 \\
1,029.1\end{array}$ & $\begin{array}{l}289.6 \\
996.0\end{array}$ & $\begin{array}{l}251.9 \\
997.5\end{array}$ \\
\hline 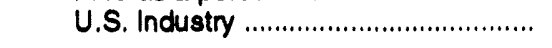 & 25.7 & 27.9 & 30.0 & 29.3 & 27.4 & 29.1 & 25.3 \\
\hline
\end{tabular}

1 U.S. area defined to include the 50 States, District of Columbia, U.S. Virgin Islands, and Puerto Rico.

2 For FRS companies, includes refinery output at own refineries for own account and at others' refineries for own account.

Note: The data for total U.S. production of crude oil and natural gas liquids and natural gas (dry) utilized in this report are taken from Energy Information Administration, Form ElA-23, see U.S. Crude Oil, Natural Gas, and Natural Gas Liquids Reserves 1992 Annual Report (October 1993). This source is utilized in order to preserve consistency between production reported in the context of oil and gas reserves and reserve additions and production reported elsewhere in this report. However, the official Energy Information Administration U.S. totals for crude oil and natural gas plant production are 3,292.5 million barrels in 1992 and 3,346.3 million barrels in 1991 (see Energy Information Administration, Petroleum Supply Annual 1992, Volume 1 (May 1993), p. 2). For dry natural gas production, the official Energy Information Administration U.S. totals are 17,775 billion cubic feet in 1992 and 17,751 billion cubic feet in 1991 (see Energy Information Administration, Natural Gas Monthly, September 1993, p. 3).

Sources: Industry data - Petroleum net production: Energy Information Administration, Form EIA-23, see U.S. Crude Oil, Natural Gas, and Natural Gas Liquids Reserves, 1992 Annual Report (October 1993). Net imports: data compiled for the Intemational Energy Agency by the Petroleum Supply Division, Office of Oil and Gas, Energy Information Administration. Refinery capacity and refinery output: Energy Information Administration, Forms EIA-820 and EIA-810, see Petroleum Supply Annual, 1991 and 1992. Coal production: Energy Information Administration, Form ElA-7A, soo Coal Production 1992 (October 1993). 
Table B3. A Comparison of Selected Financial Items for FRS Companies and the S\&P 400, 1992 and Percent Change from 1991

\begin{tabular}{|c|c|c|c|c|}
\hline \multirow[b]{2}{*}{ Solected Financlal Items } & \multicolumn{2}{|c|}{ FRS Companies } & \multicolumn{2}{|c|}{ S\&P 400} \\
\hline & $\begin{array}{c}1992 \\
\text { (bililion dollare) }\end{array}$ & $\begin{array}{c}\text { Percent Change } \\
\text { from } 1991\end{array}$ & $\begin{array}{c}1092 \\
\text { (bililon dollaro) }\end{array}$ & $\begin{array}{c}\text { Peroent Change } \\
\text { from } 1991\end{array}$ \\
\hline $\begin{array}{l}\text { Income Statement } \\
\text { Operating Revenues } \\
\text { Operating Expenses } \\
\text { Operating Income } \\
\text { Other Income } \\
\text { Income Taxes } \\
\text { Net Income }\end{array}$ & $\begin{array}{r}472.8 \\
-449.5 \\
23.3 \\
-12.9 \\
-8.6 \\
1.8\end{array}$ & $\begin{array}{r}1.9 \\
2.6 \\
-10.4 \\
1,787.1 \\
-18.8 \\
-88.0\end{array}$ & $\begin{array}{r}2,652.7 \\
-2,443.2 \\
209.5 \\
-140.2 \\
-52.6 \\
16.7\end{array}$ & $\begin{array}{r}0.6 \\
0.7 \\
-0.4 \\
69.5 \\
-4.6 \\
-76.8\end{array}$ \\
\hline 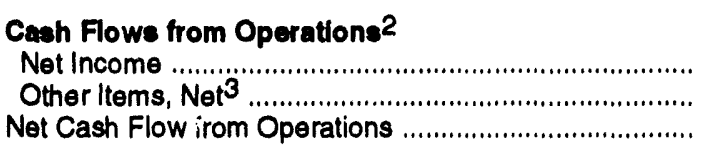 & $\begin{array}{r}1.8 \\
43.0 \\
44.8\end{array}$ & $\begin{array}{r}-88.0 \\
29.8 \\
-6.4\end{array}$ & $\begin{array}{r}16.7 \\
229.2 \\
245.9\end{array}$ & $\begin{array}{r}-76.9 \\
35.5 \\
1.7\end{array}$ \\
\hline 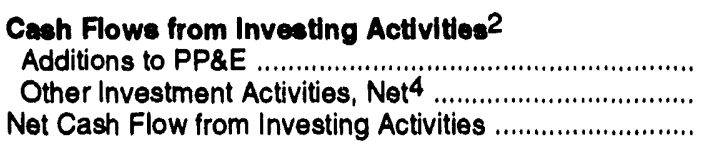 & $\begin{array}{r}-40.5 \\
4.2 \\
-36.3\end{array}$ & $\begin{array}{r}-9.8 \\
-45.7 \\
-2.4\end{array}$ & $\begin{array}{r}-167.8 \\
-26.0 \\
-193.9\end{array}$ & $\begin{array}{r}-5.9 \\
56.6 \\
-0.6\end{array}$ \\
\hline 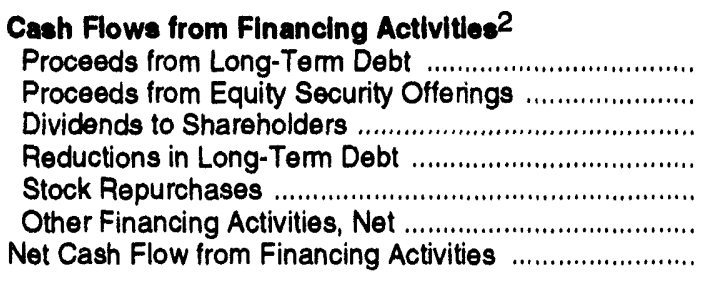 & $\begin{array}{r}24.7 \\
3.4 \\
-3.5 \\
-5.3 \\
-0.8 \\
2.3 \\
-9.1\end{array}$ & $\begin{array}{r}11.9 \\
600.2 \\
0.2 \\
37.3 \\
(5)^{-58.2} \\
-25.4\end{array}$ & $\begin{array}{r}242.1 \\
26.2 \\
-58.9 \\
-227.8 \\
-21.8 \\
-4.5 \\
-44.7\end{array}$ & $\begin{array}{r}0.0 \\
5.0 \\
2.5 \\
9.5 \\
19.8 \\
-79.2 \\
16.3\end{array}$ \\
\hline Effect of Exchange Rate Changes on Cash ............... & -0.4 & 160.1 & -2.8 & 135.6 \\
\hline Increase (Decrease) in Cash and Cash Equivalents .. & -1.0 & $\left({ }^{5}\right)$ & 4.5 & $\left({ }^{5}\right)$ \\
\hline
\end{tabular}

1 'Other Income' includes other revenue and expense, discontinued operations, extraordinary items, and accounting changes.

2 llems that add to cash are positive, and items that use cash are shown as negative values.

3 'Other Items, Net' includes: DD\&A, deferred taxes, dry hole expense, minority interest, recognized undistributed eamings/(losses) of unconsolidated affiliates, (gain)hoss on disposition of PP\&E, changes in operating assets and liabilities, and other noncash items, excluding net change in short-term debt; other cash items, net.

4 'Other Investment Activities, Net' includes additions to iivestments and advances and proceeds from disposals of PP\&E.

5 Not meaningful.

Sources: S\&P 400 data - Compustat, Inc. FRS companies' data - Energy Information Administration, Form EIA-28. 
Table B4. Consolidating Statement of Ineome for FRS Companies, 1992

(Million Dollars)

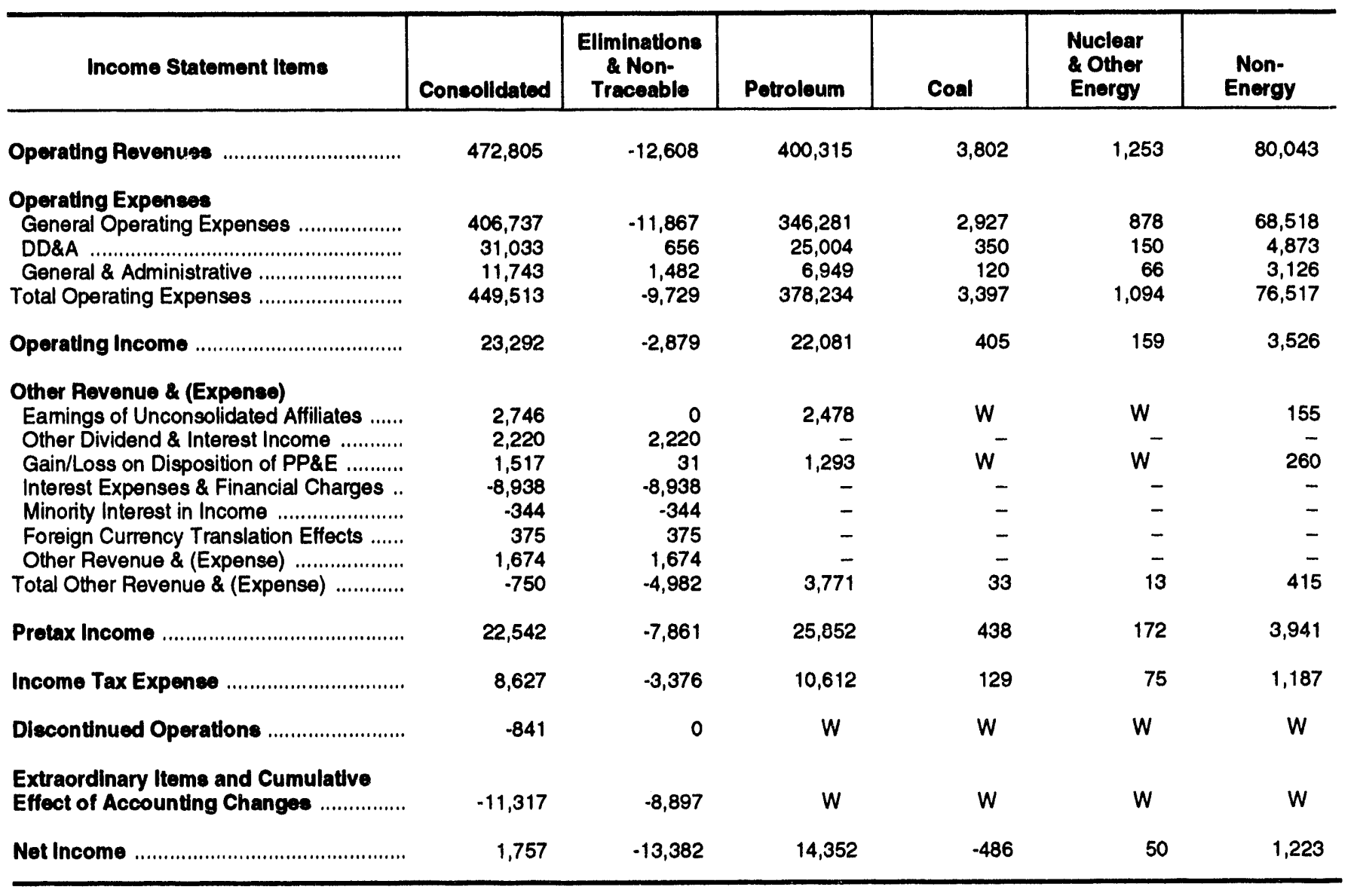

$\bar{W}=$ Not available.

W = Data withheld to avoid disclosure.

Source: Energy Information Administration, Form ElA-28. 
Table B5. Consolidating Statement of Income for FRS Companies, U.S. and Foreign Petroleum Segments, 1992

(Million Dollars)

\begin{tabular}{|c|c|c|c|c|c|c|c|c|}
\hline \multirow[b]{2}{*}{ Income Statement Iteme } & \multicolumn{4}{|c|}{ U.S. Potroleum } & \multicolumn{4}{|c|}{ Forelgn Petroleum } \\
\hline & $\begin{array}{c}\text { Consoll- } \\
\text { dated }\end{array}$ & Production & $\begin{array}{l}\text { Refining } \\
\text { Marketing }\end{array}$ & Plpelines & $\begin{array}{c}\text { Consoll- } \\
\text { dated }\end{array}$ & Production & $\begin{array}{l}\text { Rofining } \\
\text { Marketing }\end{array}$ & $\begin{array}{c}\text { Int'I } \\
\text { Marine }\end{array}$ \\
\hline 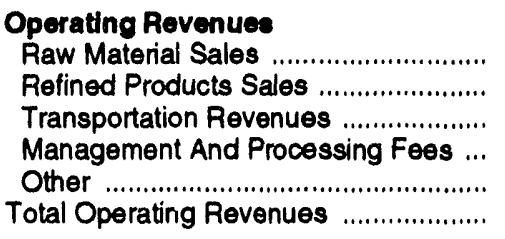 & $\begin{array}{r}87,896 \\
123,879 \\
7,035 \\
1,240 \\
7,826 \\
227,876\end{array}$ & $\begin{array}{r}46,490 \\
W \\
217 \\
W \\
1,238 \\
48,432\end{array}$ & $\begin{array}{r}72,145 \\
124,140 \\
3,160 \\
903 \\
6,847 \\
207,195\end{array}$ & $\begin{array}{r}2,101 \\
W \\
8,723 \\
W \\
220 \\
11,704\end{array}$ & $\begin{array}{r}62,537 \\
125,755 \\
1,446 \\
1,159 \\
3,212 \\
194,109\end{array}$ & $\begin{array}{r}35,753 \\
W \\
143 \\
171 \\
582 \\
36,711\end{array}$ & $\begin{array}{r}49,560 \\
125,876 \\
203 \\
1,019 \\
2,708 \\
179,366\end{array}$ & $\begin{array}{r}0 \\
0 \\
2,374 \\
W \\
W \\
2,415\end{array}$ \\
\hline $\begin{array}{l}\text { Operating Expenses } \\
\text { General Operating Expenses ............. } \\
\text { DD\&A ............................................ } \\
\text { General \& Admiristrative ................... } \\
\text { Total Operating Expenses .................... }\end{array}$ & $\begin{array}{r}195,616 \\
17,027 \\
4,583 \\
217,226\end{array}$ & $\begin{array}{r}26,473 \\
12,330 \\
1,773 \\
40,576\end{array}$ & $\begin{array}{r}201,135 \\
3,532 \\
2,402 \\
207,069\end{array}$ & $\begin{array}{r}7,427 \\
1,165 \\
454 \\
9,046\end{array}$ & $\begin{array}{r}172,301 \\
7,977 \\
2,400 \\
182,678\end{array}$ & $\begin{array}{r}20,226 \\
6,403 \\
876 \\
27,505\end{array}$ & $\begin{array}{r}174,119 \\
1,459 \\
1,527 \\
177,105\end{array}$ & $\begin{array}{r}2,279 \\
W \\
W \\
2,451\end{array}$ \\
\hline Operating Income & 10,650 & 7,856 & 126 & 2,658 & 11,431 & 9,206 & 2,261 & -36 \\
\hline $\begin{array}{l}\text { Other Revenue penee) } \\
\text { Eamings of Unce dated Affiliates } \\
\text { Gain(Loss) On Dispusition of PP\&E ... } \\
\text { Total Other Revenue \& (Expense) ....... }\end{array}$ & $\begin{array}{r}597 \\
429 \\
1,026\end{array}$ & $\begin{array}{l}130 \\
281 \\
411\end{array}$ & $\begin{array}{r}56 \\
74 \\
130\end{array}$ & $\begin{array}{r}412 \\
65 \\
477\end{array}$ & $\begin{array}{r}1,881 \\
864 \\
2,745\end{array}$ & $\begin{array}{r}1,226 \\
508 \\
1,734\end{array}$ & $\begin{array}{l}652 \\
341 \\
993\end{array}$ & $\begin{array}{l}W \\
15 \\
18\end{array}$ \\
\hline Pretax Income & 11,676 & 8,267 & 256 & 3,135 & 14,176 & 10,940 & 3,254 & -18 \\
\hline 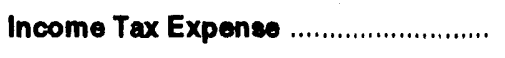 & 3,659 & 2,348 & 217 & 1,104 & 6,953 & 5,929 & 1,020 & 4 \\
\hline Dlecontinued Operations ..................... & W & W & W & $w$ & $w$ & $w$ & 0 & 0 \\
\hline $\begin{array}{l}\text { Extraordinary Items and Cumulattve } \\
\text { Effect of Accounting Changes }\end{array}$ & $w$ & W & W & $w$ & W & W & 0 & 0 \\
\hline Contribution To Net Income ............... & 7,483 & 5,588 & -213 & 2,080 & 6,869 & 4,657 & 2,234 & .22 \\
\hline
\end{tabular}

$W=$ Data withheld to avoid disclosure.

Source: Energy Information Administration, Form ElA-28. 
Table B6. Profit Rates for Lines of Business and Petroleum Segments for FRS Companies, 1986-1992 (Percent)

\begin{tabular}{|c|c|c|c|c|c|c|c|}
\hline Line of Bualnese & 1986 & 1987 & 1988 & 1989 & 1990 & 1991 & 1992 \\
\hline 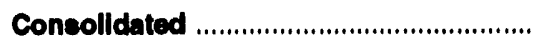 & 3.0 & 3.6 & 7.2 & 6.4 & 6.8 & 4.5 & 0.5 \\
\hline 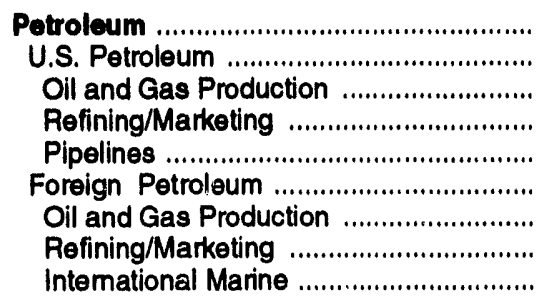 & $\begin{array}{r}5.5 \\
3.0 \\
0.8 \\
4.5 \\
13.2 \\
12.8 \\
11.6 \\
16.3 \\
5.3\end{array}$ & $\begin{array}{r}6.2 \\
4.9 \\
4.1 \\
2.9 \\
12.8 \\
9.5 \\
9.5 \\
12.4 \\
4.7 \\
-3.6\end{array}$ & $\begin{array}{r}7.3 \\
6.3 \\
2.8 \\
14.7 \\
9.6 \\
9.9 \\
9.2 \\
11.6 \\
6.8\end{array}$ & $\begin{array}{r}6.7 \\
5.8 \\
2.9 \\
11.5 \\
10.2 \\
8.7 \\
8.9 \\
8.0 \\
12.4\end{array}$ & $\begin{array}{r}9.5 \\
7.9 \\
8.5 \\
5.1 \\
11.2 \\
12.5 \\
13.1 \\
11.2 \\
11.7\end{array}$ & $\begin{array}{r}7.0 \\
4.9 \\
5.1 \\
2.0 \\
10.7 \\
11.0 \\
9.1 \\
14.6 \\
15.6\end{array}$ & $\begin{array}{r}5.6 \\
4.4 \\
5.9 \\
-0.4 \\
8.4 \\
7.9 \\
8.2 \\
7.8 \\
-1.2\end{array}$ \\
\hline 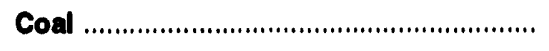 & 2.7 & 5.1 & 6.7 & 5.0 & 3.3 & 8.7 & -9.3 \\
\hline Nuclear and Other Energy .......................... & .0 .8 & 0.5 & -2.5 & -2.3 & 2.6 & 2.8 & 1.8 \\
\hline 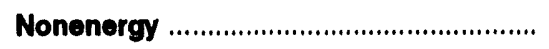 & 5.1 & 12.2 & 20.3 & 17.3 & 7.8 & 2.9 & 2.1 \\
\hline
\end{tabular}

Note: Profit rate measured as contribution to net income/net investment in place.

Source: Energy Information Administration, Form EIA-28. 
Table B7. Profit Rates for Petroleum Segments for FRS Companies Ranked by Total Energy Assets, 1990-1982

\section{(Percent)}

\begin{tabular}{|c|c|c|c|c|c|c|c|c|c|}
\hline \multirow{2}{*}{ Petroleum Segments } & \multicolumn{3}{|c|}{ Top Four } & \multicolumn{3}{|c|}{ Five Through Twelve } & \multicolumn{3}{|c|}{ All Other } \\
\hline & 1990 & 1991 & 1992 & 1990 & 1991 & 1992 & 1990 & 1991 & 1992 \\
\hline 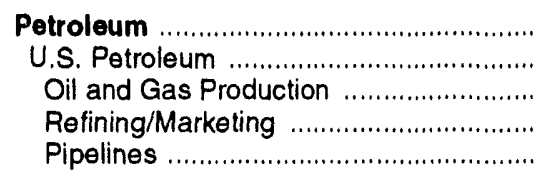 & $\begin{array}{r}9.9 \\
6.4 \\
7.2 \\
2.2 \\
20.4\end{array}$ & $\begin{array}{r}8.9 \\
3.5 \\
3.3 \\
1.8 \\
16.8\end{array}$ & $\begin{array}{r}8.1 \\
5.4 \\
6.8 \\
1.3 \\
16.2\end{array}$ & $\begin{array}{l}9.0 \\
8.5 \\
9.3 \\
5.8 \\
9.5\end{array}$ & $\begin{array}{l}5.9 \\
6.2 \\
6.6 \\
3.4 \\
9.9\end{array}$ & $\begin{array}{l}4.1 \\
4.6 \\
5.5 \\
0.6 \\
6.6\end{array}$ & $\begin{array}{r}9.3 \\
9.5 \\
9.2 \\
9.7 \\
10.0\end{array}$ & $\begin{array}{r}4.0 \\
4.0 \\
5.1 \\
-0.7 \\
9.2\end{array}$ & $\begin{array}{r}2.5 \\
2.5 \\
5.0 \\
-4.9 \\
9.9\end{array}$ \\
\hline $\begin{array}{l}\text { Foreign Petroleum } \\
\text { Oil and Gas Production } \\
\text { Refining/Marketing } \\
\text { Intemational Marine }\end{array}$ & $\begin{array}{r}13.7 \\
16.8 \\
9.4 \\
12.5\end{array}$ & $\begin{array}{l}14.1 \\
13.9 \\
14.3 \\
13.8\end{array}$ & $\begin{array}{r}10.7 \\
13.4 \\
8.0 \\
1.1\end{array}$ & $\begin{array}{r}10.7 \\
8.3 \\
42.7 \\
8.0\end{array}$ & $\begin{array}{r}4.7 \\
2.5 \\
28.4 \\
33.5\end{array}$ & $\begin{array}{r}1.8 \\
0.9 \\
13.7 \\
-27.7\end{array}$ & $\begin{array}{r}8.5 \\
8.9 \\
5.8 \\
-12.5\end{array}$ & $\begin{array}{r}4.1 \\
4.4 \\
2.1 \\
-5.9\end{array}$ & $\begin{array}{r}2.4 \\
3.3 \\
-5.8 \\
16.7\end{array}$ \\
\hline
\end{tabular}

Note: Profit rate measured as contribution to net income/net investment in place.

Source: Energy Information Administration, Form ElA-28. 
Table B8. A Comparison of Balance Sheet Items for FRS Companies and the S\&P 400, 1992 and Percent Change from 1991

\begin{tabular}{|c|c|c|c|c|}
\hline \multirow[b]{2}{*}{ Balance Sheet Items } & \multicolumn{2}{|c|}{ FRS Companies } & \multicolumn{2}{|c|}{ S\&P 400} \\
\hline & $\begin{array}{c}1992 \\
\text { (billion dollars) }\end{array}$ & $\begin{array}{c}\text { Percent Change } \\
\text { from } 1991\end{array}$ & $\begin{array}{c}1992 \\
\text { (billion dollars) }\end{array}$ & $\begin{array}{c}\text { Percent Change } \\
\text { from } 1991\end{array}$ \\
\hline \multicolumn{5}{|l|}{ Assets } \\
\hline \multicolumn{5}{|l|}{$\begin{array}{l}\text { Noncurrent Assets } \\
\text { Property, Plant, and Equipment }\end{array}$} \\
\hline 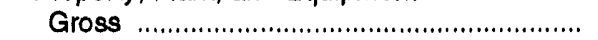 & 599.9 & 3.2 & $1,808.3$ & 2.2 \\
\hline Accumulated DD\&A .................................... & -290.2 & 5.2 & -827.1 & 4.3 \\
\hline Net & 309.7 & 1.3 & 981.2 & 0.5 \\
\hline Investments and Advances ............................ & 21.9 & 9.0 & 61.2 & -6.0 \\
\hline 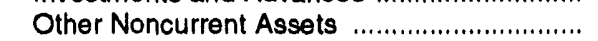 & 24.2 & 17.6 & $1,115.2$ & 2.4 \\
\hline 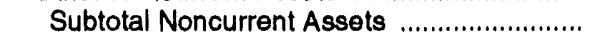 & 355.7 & 2.8 & $2,157.7$ & 1.3 \\
\hline 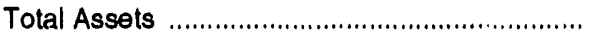 & 453.6 & 1.5 & $2,834.6$ & 1.0 \\
\hline \multicolumn{5}{|l|}{ Liablilties and Stockholders' Equity } \\
\hline \multicolumn{5}{|l|}{ Liabilities } \\
\hline 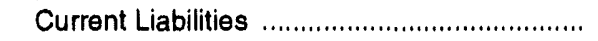 & 101.9 & -2.1 & 642.3 & 3.0 \\
\hline Long-Term Debt ............................................ & 93.5 & 2.8 & 583.6 & -1.4 \\
\hline Other Long-Term Items .................................... & 96.1 & 19.7 & 774.1 & 12.9 \\
\hline 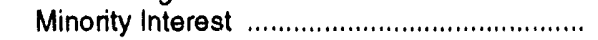 & 4.8 & 14.0 & 24.2 & 12.0 \\
\hline Subtotal Liabilities and Other Items ............. & 296.3 & 6.0 & $2,024.3$ & 5.3 \\
\hline \multicolumn{5}{|l|}{ Stockholders' Equity } \\
\hline 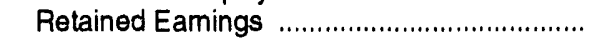 & 139.2 & -6.6 & 660.3 & -11.5 \\
\hline 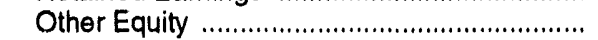 & 18.1 & -2.6 & 150.0 & 8.3 \\
\hline 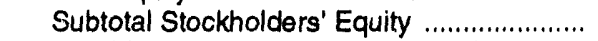 & 157.3 & -6.1 & 810.3 & -8.4 \\
\hline Total Liabilities and Stockholders' Equity ........... & 453.6 & 1.5 & $2,834.6$ & 1.0 \\
\hline
\end{tabular}

Sources: S\&P 400 data - Compustat, Inc. FRS companies' data - Energy Information Administration, Form EIA-28. 
Table B9. Consolidated Balance Sheet for FRS Companles, 1986-1992

(Billion Dollars)

\begin{tabular}{|c|c|c|c|c|c|c|c|}
\hline Balance Sheet Items & 1986 & 1987 & 1988 & 1989 & 1990 & 1991 & 1992 \\
\hline \multicolumn{8}{|l|}{ Aseats } \\
\hline \multicolumn{8}{|l|}{ Current Assets } \\
\hline $\begin{array}{l}\text { Cash \& Marketable Securities ................... } \\
\text { Trade Accounts and Notes Receivable ..... } \\
\text { Inventories }\end{array}$ & $\begin{array}{l}25.2 \\
34.9\end{array}$ & $\begin{array}{l}25.7 \\
40.2\end{array}$ & $\begin{array}{l}16.8 \\
43.7\end{array}$ & $\begin{array}{l}16.4 \\
45.4\end{array}$ & $\begin{array}{l}14.9 \\
56.6\end{array}$ & $\begin{array}{l}12.4 \\
47.2\end{array}$ & $\begin{array}{l}12.1 \\
44.6\end{array}$ \\
\hline 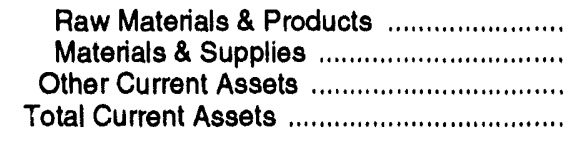 & $\begin{array}{r}26.7 \\
5.5 \\
11.1 \\
103.3\end{array}$ & $\begin{array}{r}29.1 \\
5.6 \\
8.8 \\
109.4\end{array}$ & $\begin{array}{r}26.9 \\
5.3 \\
12.2 \\
105.0\end{array}$ & $\begin{array}{r}26.2 \\
5.3 \\
9.2 \\
102.4\end{array}$ & $\begin{array}{r}28.0 \\
5.3 \\
10.5 \\
115.4\end{array}$ & $\begin{array}{r}27.0 \\
5.2 \\
9.2 \\
101.0\end{array}$ & $\begin{array}{r}26.2 \\
4.6 \\
10.4 \\
97.9\end{array}$ \\
\hline \multicolumn{8}{|l|}{$\begin{array}{l}\text { Non-current Assets } \\
\text { Property, Plant \& Equipment }\end{array}$} \\
\hline Gross & 495.2 & 525.5 & 526.7 & 536.0 & 565.0 & 581.4 & 599.9 \\
\hline Accumulated DD\&A & 204.1 & 227.9 & 233.0 & 242.8 & 262.5 & 275.9 & 290.2 \\
\hline Investments \& Advances to & 291.1 & 297.6 & 293.6 & 293.2 & 302.5 & 305.5 & 309.7 \\
\hline 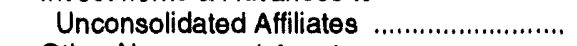 & 18.9 & 18.8 & 16.0 & 16.7 & 17.2 & 20.1 & 21.9 \\
\hline Other Non-current Assets ............................ & 13.8 & 17.9 & 23.2 & 22.2 & 22.2 & 20.6 & 24.2 \\
\hline 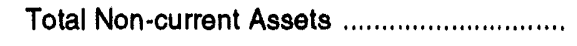 & 323.7 & 334.2 & 332.8 & 332.1 & 341.8 & 346.2 & 355.7 \\
\hline Total Assets & 427.0 & 443.6 & 437.8 & 434.5 & 457.2 & 447.1 & 453.6 \\
\hline $\begin{array}{l}\text { Liabilities \& Stockholder's Equity } \\
\text { Liabilities } \\
\text { Current Liabilities }\end{array}$ & & & & & & & \\
\hline Trade Accounts \& Notes Payable ............ & 42.5 & 48.3 & 45.9 & 51.9 & 64.6 & 56.5 & 53.1 \\
\hline Other Current Liabilities ............................. & 46.5 & 49.6 & 48.5 & 47.1 & 50.2 & 47.6 & 48.7 \\
\hline Long Term Debt .......................................... & 92.1 & 95.3 & 93.2 & 90.7 & 88.5 & 90.9 & 93.5 \\
\hline Deferred Income Tax Credits ........................ & 49.2 & 51.1 & 50.4 & 49.8 & 50.3 & 47.0 & 44.7 \\
\hline Other Deferred Credits ................................ & 10.7 & 10.8 & 11.8 & 10.9 & 12.3 & 12.2 & 16.5 \\
\hline Other Long Term Items & 18.7 & 19.7 & 19.4 & 19.3 & 19.8 & 21.1 & 34.9 \\
\hline Minority Interest in Consolidated Affiliates & 2.9 & 3.4 & 3.6 & 4.2 & 4.4 & 4.2 & 4.8 \\
\hline Total Liabilities ............................................... & 262.4 & 278.2 & 272.9 & 273.9 & 290.1 & 279.6 & 296.3 \\
\hline \multicolumn{8}{|l|}{ Stockholders' Equity } \\
\hline Retained Eamings & 144.8 & 143.2 & 143.8 & 140.9 & 148.7 & 148.9 & 139.2 \\
\hline 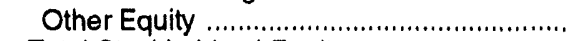 & 19.8 & 22.2 & 21.0 & 19.7 & 18.4 & 18.6 & 18.1 \\
\hline Total Stockholders' Equity ................................. & 164.6 & 165.5 & 164.8 & 160.6 & 167.1 & 167.6 & 157.3 \\
\hline Total Llabilitles \& Stockholders' Equity .... & 427.0 & 443.6 & 437.8 & 434.5 & 457.2 & 447.1 & 453.6 \\
\hline \multicolumn{8}{|l|}{$\begin{array}{l}\text { Memo: } \\
\text { Foreign Currency Translation Adjustment }\end{array}$} \\
\hline $\begin{array}{l}\text { Cumulative at Year End ............................... } \\
\text { Foreign Currency Translation Adjustment }\end{array}$ & -2.2 & -4.0 & -4.7 & -4.3 & -3.3 & -3.2 & -6.6 \\
\hline 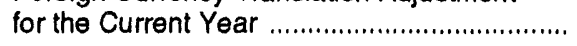 & 1.8 & 3.4 & -0.5 & -0.5 & 1.9 & 0.1 & -3.3 \\
\hline
\end{tabular}

Source: Energy Information Administration, Form ElA-28. 
Table B10. Distribution of Net Investment In Place for FRS Companies, United States and Forelgn, 1992

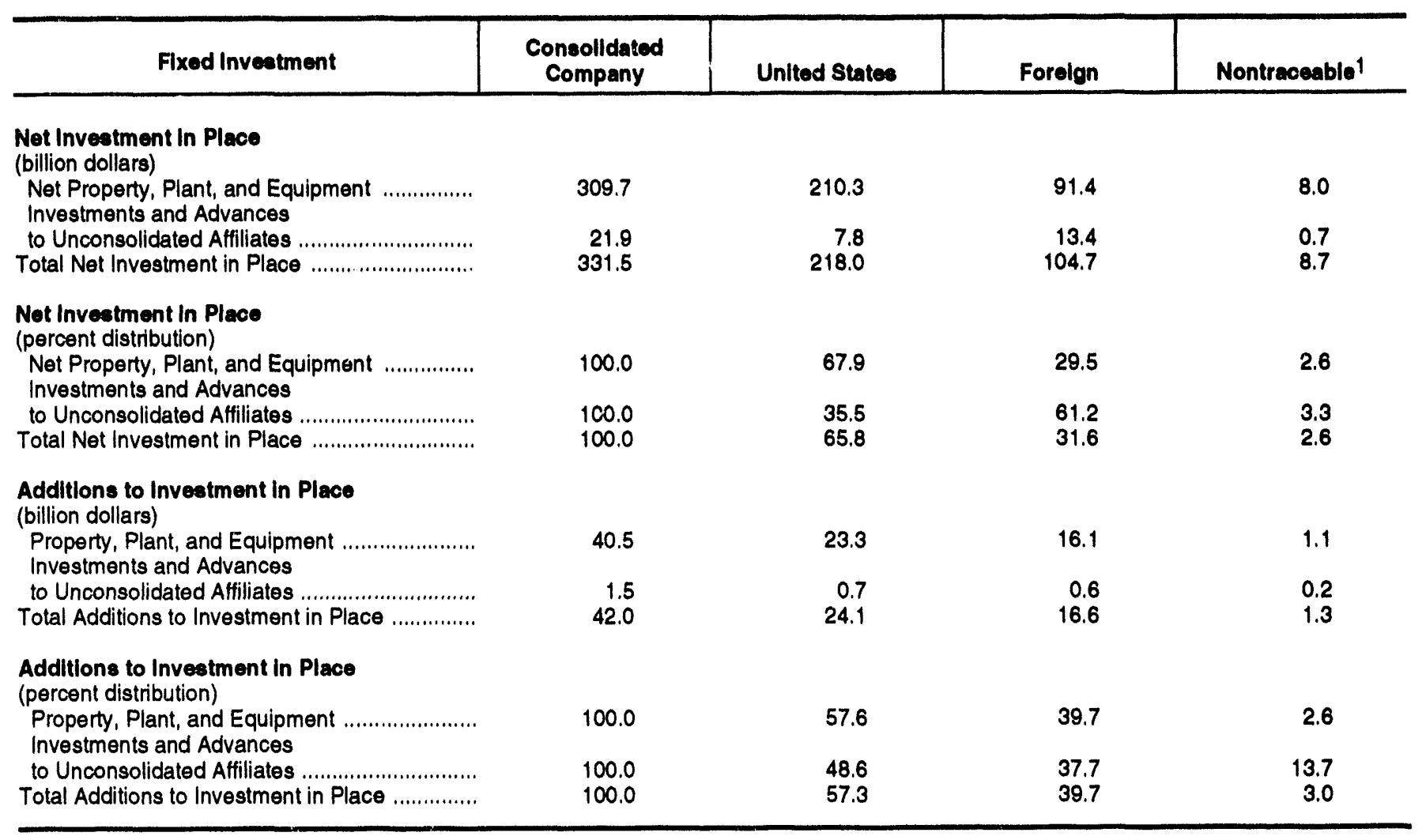

1 Includes items in consolidated balance sheet that cannot be allocated to segments (nontraceables). In this table, this column is derived as a residual.

Source: Energy Information Administration, Form ElA-28. 
Table B11. Net Property, Plant and Equipment (PP\&E), Addlitions to PP\&E, Investments and Advances, and Depreciation, Depletion and Amortization (DD\&A), by Lines of Business for FRS Companies, 1992 (Million Dollars)

\begin{tabular}{|c|c|c|c|c|c|}
\hline \multirow[b]{2}{*}{ Line of Businese } & \multicolumn{2}{|c|}{ Year End Balance } & \multicolumn{3}{|c|}{ Actlvity During Year } \\
\hline & Not PP\&E & $\begin{array}{l}\text { Inveatmente } \\
\text { and } \\
\text { Advances }\end{array}$ & $\begin{array}{l}\text { Additions } \\
\text { to PP\&E }\end{array}$ & $\begin{array}{l}\text { Additione } \\
\text { to Investments } \\
\text { and Advances }\end{array}$ & DD\&A \\
\hline 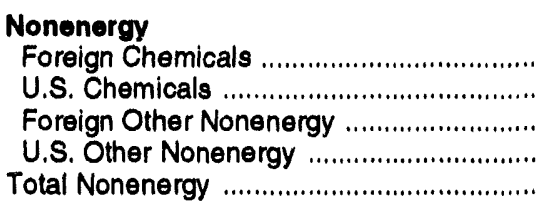 & $\begin{array}{r}8,436 \\
26,931 \\
3,306 \\
14,739 \\
53,412\end{array}$ & $\begin{array}{r}2,241 \\
1,542 \\
284 \\
1,254 \\
5,322\end{array}$ & $\begin{array}{r}1,644 \\
4,164 \\
380 \\
1,612 \\
7,800\end{array}$ & $\begin{array}{r}225 \\
64 \\
W \\
W \\
468\end{array}$ & $\begin{array}{r}805 \\
2,973 \\
W \\
W \\
4,873\end{array}$ \\
\hline 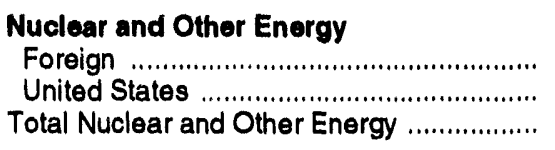 & $\begin{array}{l}1,273 \\
1,435 \\
2,708\end{array}$ & $\begin{array}{c}W \\
W \\
123\end{array}$ & $\begin{array}{r}133 \\
27 \\
160\end{array}$ & $\begin{array}{l}W \\
W \\
W\end{array}$ & $\begin{array}{r}81 \\
69 \\
150\end{array}$ \\
\hline 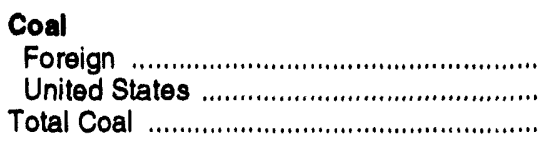 & $\begin{array}{r}W \\
W \\
4,179\end{array}$ & $\begin{array}{c}W \\
W \\
1,047\end{array}$ & $\underset{624}{W}$ & $\underset{307}{W}$ & $\begin{array}{r}W \\
W \\
350\end{array}$ \\
\hline $\begin{array}{l}\text { Petroleum } \\
\text { United States } \\
\text { Production } \\
\text { Refining/Marketing }\end{array}$ & 94,342 & 792 & 8,793 & $\cdot$ & 12,330 \\
\hline 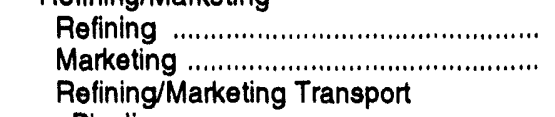 & $\begin{array}{l}26,781 \\
16,286\end{array}$ & $\begin{array}{l}892 \\
323\end{array}$ & $\begin{array}{l}5,144 \\
1,898\end{array}$ & $\begin{array}{l}28 \\
10\end{array}$ & $\begin{array}{l}1,982 \\
1,206\end{array}$ \\
\hline 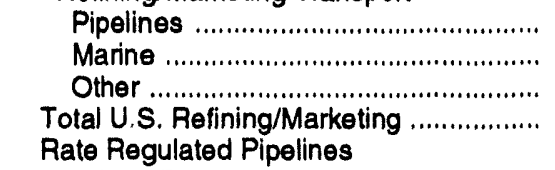 & $\begin{array}{r}1,658 \\
1,924 \\
746 \\
47,395\end{array}$ & $\begin{array}{r}85 \\
W \\
W \\
1,357\end{array}$ & $\begin{array}{r}178 \\
55 \\
112 \\
7,387\end{array}$ & $\begin{array}{l}11 \\
W \\
W \\
55\end{array}$ & $\begin{array}{r}126 \\
157 \\
61 \\
3,532\end{array}$ \\
\hline 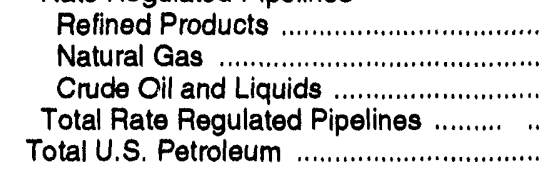 & $\begin{array}{r}1,270 \\
15,375 \\
6,386 \\
23,031 \\
164,768\end{array}$ & $\begin{array}{r}336 \\
871 \\
491 \\
1,698 \\
3,847\end{array}$ & $\begin{array}{r}96 \\
518 \\
325 \\
939 \\
17,119\end{array}$ & $\begin{array}{r}W \\
56 \\
W \\
66 \\
132\end{array}$ & $\begin{array}{r}73 \\
620 \\
472 \\
1,165 \\
17,027\end{array}$ \\
\hline 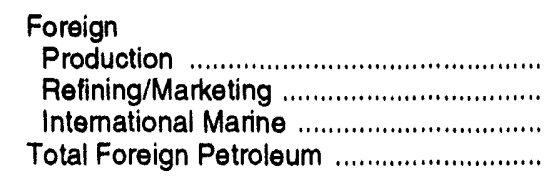 & $\begin{array}{r}53,841 \\
20,914 \\
1,836 \\
76,591\end{array}$ & $\begin{array}{r}3,187 \\
7,599 \\
6 \\
10,792\end{array}$ & $\begin{array}{r}9,967 \\
3,520 \\
225 \\
13,712\end{array}$ & $\begin{array}{c}202 \\
W \\
W \\
298\end{array}$ & $\begin{array}{r}6,403 \\
1,459 \\
115 \\
7,977\end{array}$ \\
\hline 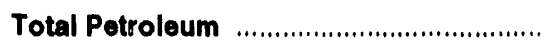 & 241,359 & 14,639 & 30,831 & 430 & 25,004 \\
\hline 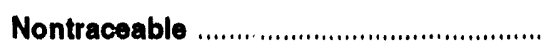 & 8,005 & 730 & 1,063 & W & 6ES \\
\hline 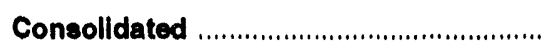 & 309,663 & 21,861 & 40,478 & 1,483 & 31,033 \\
\hline
\end{tabular}

$W=$ Data withheld to avoid disclosure.

Source: Energy Information Administration, Form ElA-28. 
Table B12. Income and Investment Patterns in Worldwide Petroleum for FRS Companies Ranked by Total Energy Assets, 1992 and Percent Change from 1991

\begin{tabular}{|c|c|c|c|}
\hline Income and Inveatment & Worldwide & United Statee & Forelgn \\
\hline & \multicolumn{3}{|c|}{ (million dollars) } \\
\hline \multicolumn{4}{|l|}{$\begin{array}{l}1992 \\
\text { Contribution to Net Income }\end{array}$} \\
\hline Top Four & $9,294.0$ & $3,002.0$ & $6,292.0$ \\
\hline 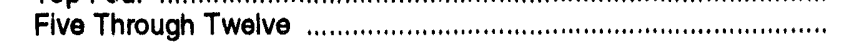 & $3,939,0$ & $3,593.0$ & 346.0 \\
\hline 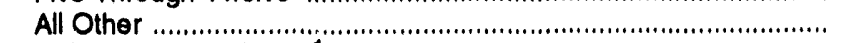 & $1,119.0$ & 888.0 & 231.0 \\
\hline \multicolumn{4}{|l|}{ Net Investment in Place 1} \\
\hline Top Four & $114,244.0$ & $55,290.0$ & $58,954.0$ \\
\hline Five Through Twelve & $96,947.0$ & $78,244.0$ & $18,703.0$ \\
\hline All Other & $44,807.0$ & $35,081.0$ & $9,726.0$ \\
\hline \multicolumn{4}{|l|}{ Additions to Investment in Place } \\
\hline \multirow{4}{*}{ 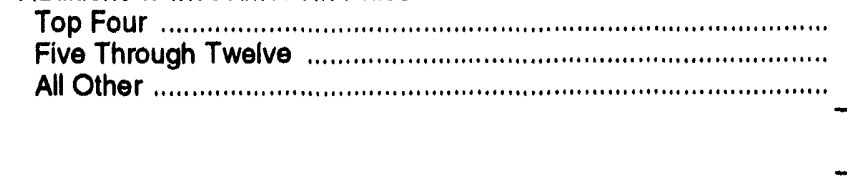 } & $14,024.0$ & $5,588.0$ & $8,436.0$ \\
\hline & $10,648.0$ & $6,957.0$ & $3,681.0$ \\
\hline & $6,589.0$ & $4,706.0$ & $1,883.0$ \\
\hline & \multicolumn{3}{|c|}{ (percent) } \\
\hline \multirow{2}{*}{\multicolumn{4}{|c|}{$\begin{array}{l}\text { Distrlbution, } 1992 \\
\text { Contribution to Net Income }\end{array}$}} \\
\hline & & & \\
\hline Top Four & 100.0 & 32.3 & 67.7 \\
\hline 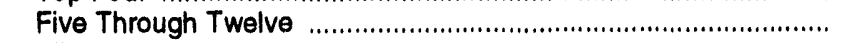 & 100.0 & 91.2 & 8.8 \\
\hline 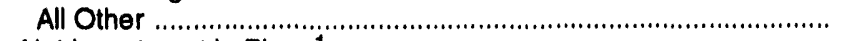 & 100.0 & 79.4 & 20.6 \\
\hline \multicolumn{4}{|l|}{ Net Investment in Place 1} \\
\hline 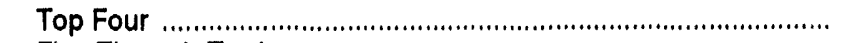 & 100.0 & 48.4 & 51.6 \\
\hline Five Through Twelve & 100.0 & 80.7 & 19.3 \\
\hline 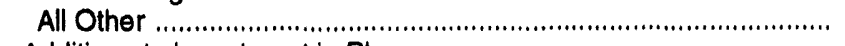 & 100.0 & 78.3 & 21.7 \\
\hline \multicolumn{4}{|l|}{ Additions to Investment in Place } \\
\hline 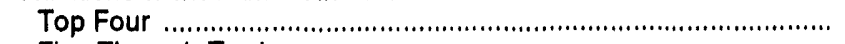 & 100.0 & 39.8 & 60.2 \\
\hline 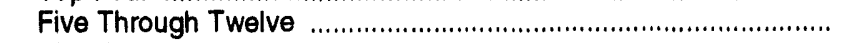 & 100.0 & 65.3 & 34.7 \\
\hline 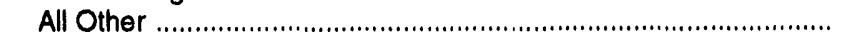 & 100.0 & 71.4 & 28.6 \\
\hline \multicolumn{4}{|l|}{ Change from 1991} \\
\hline \multicolumn{4}{|l|}{ Contribution to Net Income } \\
\hline Top Four & -11.2 & 49.7 & -25.7 \\
\hline 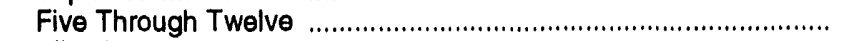 & -31.2 & -24.4 & -64.4 \\
\hline 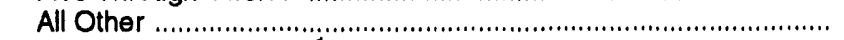 & -26.3 & -24.9 & -31.5 \\
\hline \multicolumn{4}{|l|}{ Net Investment in Place 1} \\
\hline Top Four & -3.2 & -4.4 & -2.0 \\
\hline 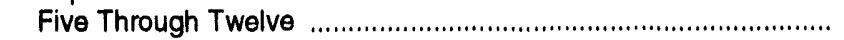 & 0.0 & 2.8 & -10.1 \\
\hline All Other & 19.2 & 19.5 & 18.0 \\
\hline \multicolumn{4}{|l|}{ Additions to Investment in Place } \\
\hline 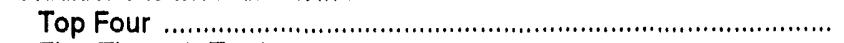 & -7.8 & -18.6 & 1.1 \\
\hline 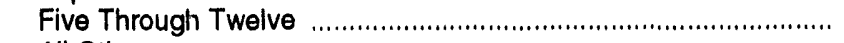 & -21.0 & -25.5 & -10.8 \\
\hline 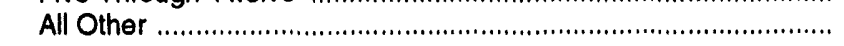 & -4.7 & -5.4 & -2.8 \\
\hline
\end{tabular}

1 Measured as net property, plant, and equipment plus inyestments and advances.

Note: Sum of components may not equal total due to independent rounding, eliminations, and nontraceables.

Source: Energy Information Administration, Form EIA-28. 
Table B13. Income and Investment Patterns by Petroleum Segments for FRS Companies Ranked by Total Energy Assets, 1992 and Percent Change from 1991

\begin{tabular}{|c|c|c|c|c|c|c|c|c|}
\hline \multirow[b]{2}{*}{ Income and Inveatment } & \multicolumn{4}{|c|}{ United States } & \multicolumn{4}{|c|}{ Forelgn } \\
\hline & $\begin{array}{l}\text { Consoll- } \\
\text { dated }\end{array}$ & Production & $\begin{array}{l}\text { Rofining } \\
\text { Marketing }\end{array}$ & Pipollnes & $\begin{array}{l}\text { Consolli- } \\
\text { dated }\end{array}$ & Produotion & $\begin{array}{l}\text { Rofining } \\
\text { Marketing }\end{array}$ & $\begin{array}{l}\text { Inter- } \\
\text { natlonal } \\
\text { Marline }\end{array}$ \\
\hline & \multicolumn{8}{|c|}{ (million dollars) } \\
\hline \multirow{3}{*}{ 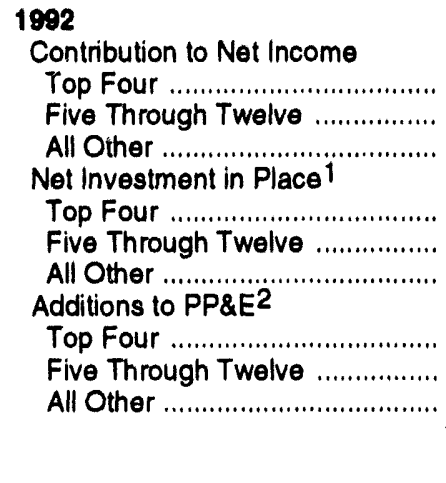 } & $\begin{array}{r}3,002.0 \\
3,593.0 \\
888.0\end{array}$ & $\begin{array}{r}2,311.0 \\
2,360.0 \\
917.0\end{array}$ & $\begin{array}{r}234.0 \\
114.0 \\
.561 .0\end{array}$ & $\begin{array}{r}457.0 \\
1,118.0 \\
505.0\end{array}$ & $\begin{array}{r}6,292.0 \\
346.0 \\
231.0\end{array}$ & $\begin{array}{r}4,221.0 \\
150.0 \\
286.0\end{array}$ & $\begin{array}{r}2,053.0 \\
240.0 \\
-59.0\end{array}$ & $\begin{array}{r}18.0 \\
-44.0 \\
4.0\end{array}$ \\
\hline & $\begin{array}{l}55,290.0 \\
78,244.0 \\
35,081.0\end{array}$ & $\begin{array}{l}33,913.0 \\
42,723.0 \\
18,498.0\end{array}$ & $\begin{array}{l}18,563.0 \\
18,706.0 \\
11,483.0\end{array}$ & $\begin{array}{r}2,814.0 \\
16,815.0 \\
5,100.0\end{array}$ & $\begin{array}{r}58,954.0 \\
18,703.0 \\
9,726.0\end{array}$ & $\begin{array}{r}31,561.0 \\
16,789.0 \\
8,678.0\end{array}$ & $\begin{array}{r}25,734.0 \\
1,755.0 \\
1,024.0\end{array}$ & $\begin{array}{r}1,659.0 \\
159.0 \\
24.0\end{array}$ \\
\hline & $\begin{array}{l}5,553.0 \\
6,925.0 \\
4,641.0\end{array}$ & $\begin{array}{l}2,816.0 \\
3,409.0 \\
2,568.0\end{array}$ & $\begin{array}{l}2,571.0 \\
3,050.0 \\
1,766.0\end{array}$ & $\begin{array}{l}166.0 \\
466.0 \\
307.0\end{array}$ & $\begin{array}{l}8,277.0 \\
3,577.0 \\
1,858.0\end{array}$ & $\begin{array}{l}4,969.0 \\
3,219.0 \\
1,779.0\end{array}$ & $\begin{array}{r}3,108.0 \\
339.0 \\
73.0\end{array}$ & $\begin{array}{r}200.0 \\
19.0 \\
6.0\end{array}$ \\
\hline
\end{tabular}

Distribution, 1992

Contribution to Net Income

All Other ...................................

Net Investment in Place 1

Top Four .................................

Five Through Twelve .................

All Other ..............................

$\begin{array}{ll}100.0 & 65.7\end{array}$

100.0

103.3

100.0

100.0

100.0

Additions to PP\&E

Top Four

Five Through Twelve

All Other

100.0

100.0

100.0

\section{3}

54.6

52.7

50.7

49.2

55.3

7.8
3.2
-63.2

33.6
23.9
32.7

46.3
44.0
38.1

$\begin{array}{rr}15.2 & 100.0 \\ 31.1 & 100.0 \\ 56.9 & 100.0 \\ & \\ 5.1 & 100.0 \\ 21.5 & 100.0 \\ 14.5 & 100.0 \\ & \\ 3.0 & 100.0 \\ 6.7 & 100.0 \\ 6.6 & 100.0\end{array}$

100.0

100.0

67.1

43.4

123.8

69.4

$-25.5$

0.3

53.5

89.8

89.2

43.7

9.4

10.5

60.0

90.0

95.7

37.5

9.5

3.9

2.8

0.9

0.2

2.4

0.5

Change from 1991

Contribution to Net Income

Top Four ...............................

All Other ..................................
Net Investment in Place 1

\begin{tabular}{|c|c|c|c|c|c|c|c|}
\hline $\begin{array}{r}49.7 \\
-24.4 \\
-24.9\end{array}$ & $\begin{array}{r}89.9 \\
-23.7 \\
24.1\end{array}$ & $\begin{array}{r}-27.6 \\
-82.3 \\
776.6\end{array}$ & $\begin{array}{r}-1.7 \\
10.1 \\
0.2\end{array}$ & $\begin{array}{l}-25.7 \\
-64.4 \\
-31.5\end{array}$ & $\begin{array}{r}-7.8 \\
-68.8 \\
-9.5\end{array}$ & $\begin{array}{l}-43.9 \\
\left(3^{-44.4}\right.\end{array}$ & $\begin{array}{l}-92.0 \\
\left(\begin{array}{l}3 \\
3\end{array}\right)\end{array}$ \\
\hline $\begin{array}{r}-4.4 \\
2.8 \\
19.5\end{array}$ & $\begin{array}{r}-8.6 \\
-9.3 \\
28.4\end{array}$ & $\begin{array}{r}3.2 \\
-0.2 \\
21.0\end{array}$ & $\begin{array}{r}1.8 \\
63.7 \\
-6.5\end{array}$ & $\begin{array}{r}-2.0 \\
-10.1 \\
18.0\end{array}$ & $\begin{array}{r}-4.2 \\
-12.1 \\
21.2\end{array}$ & $\begin{array}{r}0.5 \\
15.3 \\
-3.8\end{array}$ & $\begin{array}{r}1.8 \\
-12.6 \\
41.2\end{array}$ \\
\hline $\begin{array}{r}-18.2 \\
-23.6 \\
-5.4\end{array}$ & $\begin{array}{r}-28.7 \\
-37.8 \\
11.0\end{array}$ & $\begin{array}{r}-3.5 \\
-1.8 \\
-13.5\end{array}$ & $\begin{array}{r}-5.7 \\
-2.1 \\
-44.2\end{array}$ & $\begin{array}{r}3.9 \\
-14.0 \\
-2.4\end{array}$ & $\begin{array}{r}7.2 \\
-18.2 \\
9.1\end{array}$ & $\begin{array}{r}1.1 \\
72.1 \\
-71.7\end{array}$ & $\begin{array}{l}-22.2 \\
-32.1 \\
-57.1\end{array}$ \\
\hline
\end{tabular}

1 Measured as net property, plant, and equipment plus investments and advances.

2 Property, plant, and equipment.

3 Not meaningful.

Note: Sum of components may not equal total due to independent rounding, eliminations, and nontraceables.

Source: Energy Information Administration, Form EIA-28. 
Table B14. Size Distribution of Income and Investment Within Worldwide Petroleum for FRS Companies Ranked by Total Energy Assots, 1980-1992

(Percent)

\begin{tabular}{|c|c|c|c|c|c|c|c|c|c|}
\hline \multirow{2}{*}{$\begin{array}{l}\text { Patterne Acrose } \\
\text { Slze Croupe }\end{array}$} & \multicolumn{3}{|c|}{ Worldwids } & \multicolumn{3}{|c|}{ United States } & \multicolumn{3}{|c|}{ Fordign } \\
\hline & 1900 & 1991 & 1982 & 1800 & 1991 & 1092 & 1980 & 1991 & 1892 \\
\hline \multicolumn{10}{|l|}{ Contribution to Not Income } \\
\hline 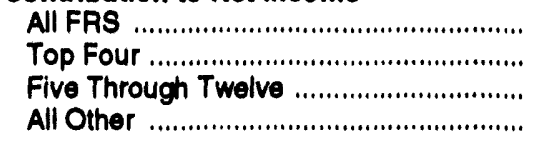 & $\begin{array}{r}100.0 \\
48.6 \\
37.5 \\
14.0\end{array}$ & $\begin{array}{r}100.0 \\
59.1 \\
32.3 \\
8.6\end{array}$ & $\begin{array}{r}100.0 \\
64.8 \\
27.4 \\
7.8\end{array}$ & $\begin{array}{r}100.0 \\
28.7 \\
51.0 \\
20.3\end{array}$ & $\begin{array}{r}100.0 \\
25.3 \\
59.9 \\
14.9\end{array}$ & $\begin{array}{r}100.0 \\
40.1 \\
48.0 \\
11.9\end{array}$ & $\begin{array}{r}100.0 \\
73.2 \\
20.7 \\
6.1\end{array}$ & $\begin{array}{r}100.0 \\
86.6 \\
10.0 \\
3.4\end{array}$ & $\begin{array}{r}100.0 \\
91.6 \\
5.0 \\
3.4\end{array}$ \\
\hline \multicolumn{10}{|l|}{ Not Investment In Pisco 1} \\
\hline 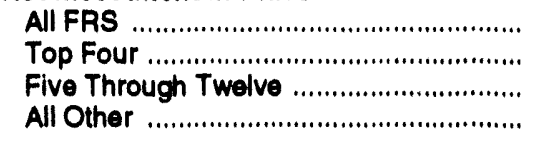 & $\begin{array}{r}100.0 \\
46.3 \\
39.4 \\
14.3\end{array}$ & $\begin{array}{r}100.0 \\
46.7 \\
38.4 \\
14.9\end{array}$ & $\begin{array}{r}100.0 \\
44.6 \\
37.9 \\
17.5\end{array}$ & $\begin{array}{r}100.0 \\
35.7 \\
47.3 \\
17.0\end{array}$ & $\begin{array}{r}100.0 \\
35.4 \\
46.6 \\
18.0\end{array}$ & $\begin{array}{r}100.0 \\
32.8 \\
46.4 \\
20.8\end{array}$ & $\begin{array}{r}100.0 \\
67.0 \\
24.1 \\
9.0\end{array}$ & $\begin{array}{r}100.0 \\
67.4 \\
23.3 \\
9.2\end{array}$ & $\begin{array}{r}100.0 \\
67.5 \\
21.4 \\
11.1\end{array}$ \\
\hline \multicolumn{10}{|l|}{ Additlons to Inveotment In Plece } \\
\hline
\end{tabular}

1 Measured as net property, plant, and equipment plus investments and advances.

Source: Energy Iniomation Administration, Form EIA-28. 


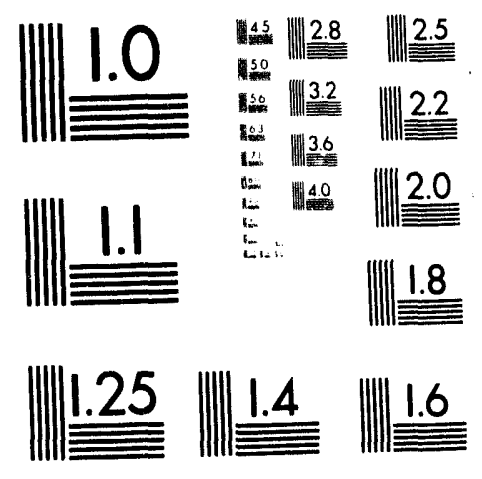



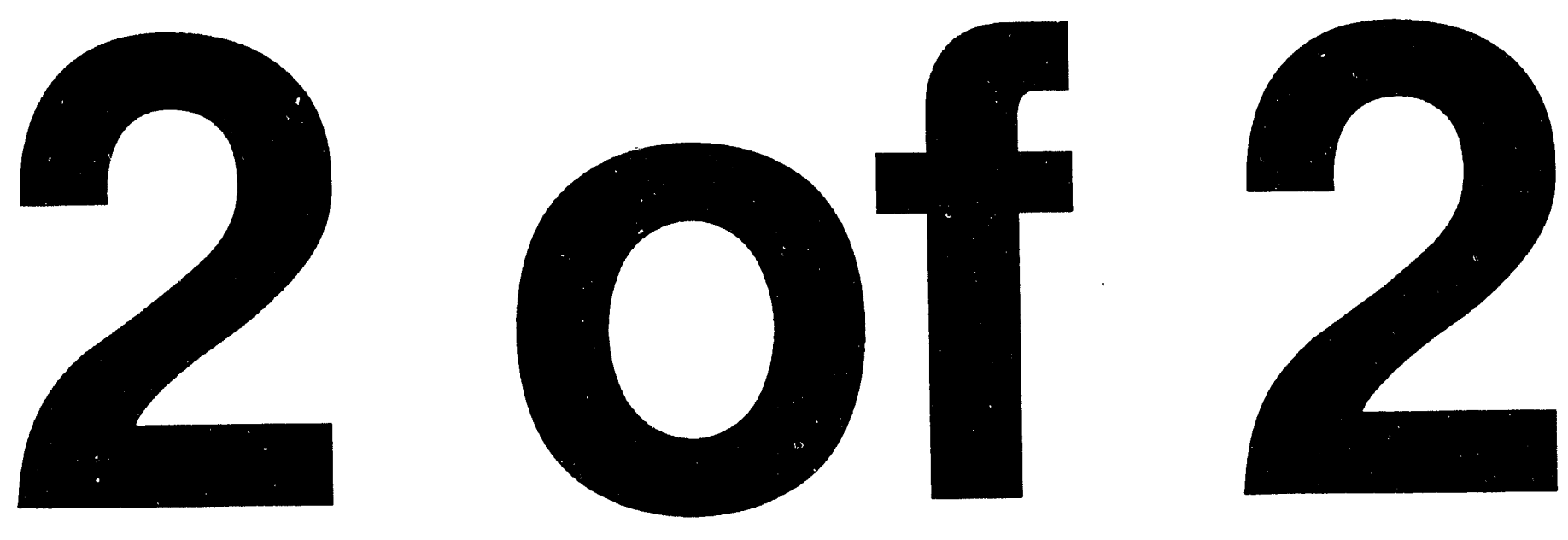
Table B15. Consolidated Statement of Cash Flows for FRS Companies, 1986-1992

(Million Dollars)

\begin{tabular}{|c|c|c|c|c|c|c|c|}
\hline Cash Flows 1 & 1986 & 1987 & 1988 & 1989 & 1990 & 1991 & 1992 \\
\hline \multicolumn{8}{|l|}{ Cash Flows From Operations } \\
\hline Net Income & 9,167 & 11,257 & 22,339 & 19,784 & 21,608 & 14,679 & 1,757 \\
\hline 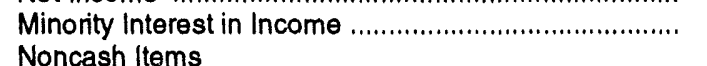 & 398 & 573 & 585 & 424 & 408 & 235 & 344 \\
\hline DD\&A & 31,239 & 30,673 & 31,052 & 29,598 & 30,739 & 30,017 & 31,033 \\
\hline Dry Hole Expense, This Year ........................ & 3,385 & 1,780 & 2,764 & 2,258 & 2,796 & 2,841 & 1,986 \\
\hline \multicolumn{4}{|l|}{ Rocognized Undistributed (Eamings)/Losses } & 189 & -39 & $-2,062$ & $-3,929$ \\
\hline 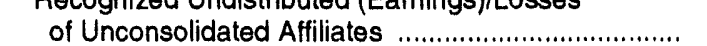 & -594 & -280 & -338 & .794 & -777 & -829 & -350 \\
\hline (Gain)/Loss on Disposition of PP\&E .............................. & $-1,573$ & $-1,561$ & $-2,064$ & $-3,335$ & .795 & $-1,808$ & $-1,294$ \\
\hline 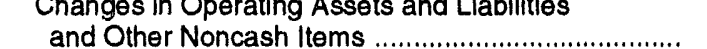 & $-3,719$ & 1,847 & $-4,741$ & 809 & 2,883 & 2,744 & 15,442 \\
\hline Other Cash Items, Net & 2,085 & 2,085 & $-2,449$ & -649 & $-1,930$ & 2,002 & -231 \\
\hline Net Cash Flow From Operations .................................... & 44,194 & 47,142 & 48,427 & 48,284 & 54,893 & 47,819 & 44,758 \\
\hline \multicolumn{8}{|l|}{ Cash Flows From Investing Activities } \\
\hline 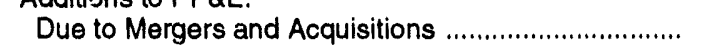 & $-9,857$ & $-5,830$ & $-15,144$ & $-8,676$ & $-3,467$ & $-1,075$ & -874 \\
\hline Other & $-27,891$ & $-28,950$ & $-34,653$ & $-34,847$ & $-41,122$ & $-43,812$ & $-39,604$ \\
\hline Total Additions to PP\&E & $-37,748$ & $-34,780$ & $-49,797$ & $-43,523$ & $-44,589$ & $-44,887$ & $-40,478$ \\
\hline 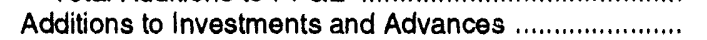 & $-1,947$ & .31 & 121 & $-1,468$ & -886 & $-1,520$ & $-1,483$ \\
\hline 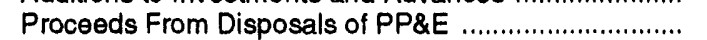 & 11,202 & 6,367 & 15,960 & 13,404 & 7,143 & 9,359 & 7,268 \\
\hline 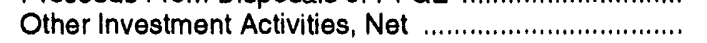 & 2,676 & $-5,347$ & 4,623 & $-2,209$ & 327 & -103 & $-1,584$ \\
\hline 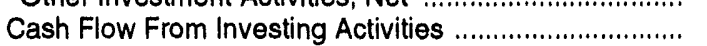 & $-25,817$ & $-33,791$ & $-29,093$ & $-33,796$ & $-38,005$ & $-37,151$ & $-36,277$ \\
\hline \multicolumn{8}{|l|}{ Cash Flows From Financing Activities } \\
\hline Proceeds From Long-Term Debt ................................. & 30,431 & 19,748 & 19,313 & 20,668 & 15,759 & 22,120 & 24,745 \\
\hline Proceeds From Equity Security Offerings .................... & 5,048 & 2,312 & 2,709 & 4,248 & 1,501 & 491 & 3,438 \\
\hline Reductions in Lona-Term Debt & -30.068 & -20209 & -28.775 & .19 .820 & $-17,223$ & $-18,411$ & $.25,284$ \\
\hline Purchase of Treasury Stock & $-2,794$ & $-3,839$ & $-6,637$ & $-6,190$ & $-5,435$ & $-1,973$ & -824 \\
\hline 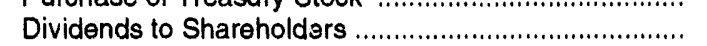 & $-11,319$ & $-10,593$ & $-12,443$ & $-16,699$ & $-13,300$ & $-13,497$ & $-13,521$ \\
\hline Other Financing Activities, Including Net Change & & & & & & & \\
\hline 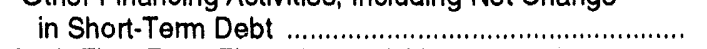 & $-4,568$ & $-2,478$ & 413 & 2,111 & 243 & -978 & 2,308 \\
\hline Cash Flow From Financing Activities .............................. & $-13,270$ & $.15,059$ & $-25,420$ & $-15,682$ & $-18,455$ & $-12,248$ & $-9,138$ \\
\hline 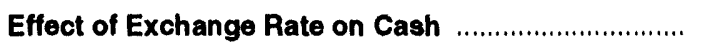 & 127 & 457 & -247 & -286 & 74 & -138 & -359 \\
\hline \multicolumn{8}{|l|}{ Net Increase/(Decrease) in Cash and Cash } \\
\hline 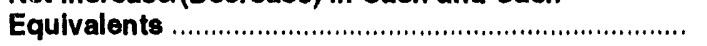 & 5,234 & $-1,251$ & $-6,333$ & $-1,480$ & $-1,493$ & $-1,718$ & $\cdot 1,016$ \\
\hline
\end{tabular}

1 Items that add to cash are positive, and items that use cash are shown as negative values.

Source: Energy Information Administration, Form EIA-28. 
Table B16. A Comparison of Key Financial Indicators, Selected Performance Measures, and Patterns of Finance for FRS Companies and for the S\&P 400, 1990-1992

(Percent)

\begin{tabular}{|c|c|c|c|c|c|c|}
\hline \multirow{2}{*}{ Financial Indicatore } & \multicolumn{3}{|c|}{ FRS Companies } & \multicolumn{3}{|c|}{ S\&P 400} \\
\hline & 1990 & 1991 & 1992 & 1990 & 1991 & 1992 \\
\hline $\begin{array}{l}\text { Profitabllity Measure } \\
\text { Net Income to Total Assets .......................................... } \\
\text { Net Income to Stockholders' Equity ........................... } \\
\text { Net Income Plus Interest to Total Invested Capital ........ }\end{array}$ & $\begin{array}{r}4.7 \\
12.9 \\
12.8\end{array}$ & $\begin{array}{l}3.3 \\
8.8 \\
9.5\end{array}$ & $\begin{array}{l}0.4 \\
1.1 \\
4.3\end{array}$ & $\begin{array}{r}4.1 \\
13.0 \\
14.1\end{array}$ & $\begin{array}{r}2.6 \\
8.2 \\
10.7\end{array}$ & $\begin{array}{l}0.6 \\
2.1 \\
6.5\end{array}$ \\
\hline $\begin{array}{l}\text { Cash Flow from Operations and Usea of Cash } \\
\text { Net Cash Flow from Operations to Total Assets ............ } \\
\text { Additions to PP\&E to Net Cash Flow from Operations... } \\
\text { Dividends to Net Cash Flow from Operations ..................... }\end{array}$ & $\begin{array}{l}12.0 \\
81.2 \\
24.2\end{array}$ & $\begin{array}{l}10.7 \\
93.9 \\
28.2\end{array}$ & $\begin{array}{r}9.9 \\
90.4 \\
30.2\end{array}$ & $\begin{array}{r}8.8 \\
76.3 \\
24.1\end{array}$ & $\begin{array}{r}8.6 \\
73.8 \\
23.8\end{array}$ & $\begin{array}{r}8.7 \\
68.2 \\
24.0\end{array}$ \\
\hline 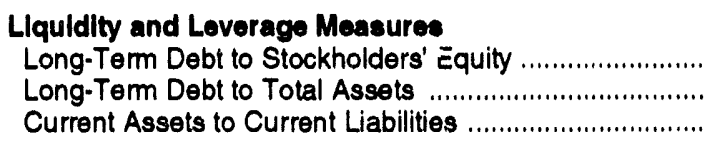 & $\begin{array}{r}53.0 \\
19.4 \\
100.5\end{array}$ & $\begin{array}{l}54.3 \\
20.3 \\
97.0\end{array}$ & $\begin{array}{l}59.4 \\
20.6 \\
96.1\end{array}$ & $\begin{array}{r}65.4 \\
20.8 \\
109.6\end{array}$ & $\begin{array}{r}66.9 \\
21.1 \\
108.6\end{array}$ & $\begin{array}{r}72.0 \\
20.6 \\
105.4\end{array}$ \\
\hline
\end{tabular}

Sources: S\&P 400 data - Compustat, Inc. FRS companies' data - Energy Information Administration, Form ElA-28. 
Table B17. Worldwide Income Taxes for FRS Companies, 1991 and 1992

\begin{tabular}{|c|c|c|c|c|c|}
\hline \multirow{2}{*}{$\begin{array}{c}\text { Taxes by } \\
\text { Geographlc Sector }\end{array}$} & \multicolumn{2}{|c|}{ Bililon Dollars } & \multirow{2}{*}{$\begin{array}{l}\text { Percent Change } \\
\text { from } 1991\end{array}$} & \multicolumn{2}{|c|}{$\begin{array}{c}\text { Income Taxes as a } \\
\text { Percent of Pretax Income }\end{array}$} \\
\hline & 1991 & 1992 & & 1991 & 1992 \\
\hline Pretax Income ${ }^{1}$ & 25.1 & 22.5 & -10.3 & 100.0 & 100.0 \\
\hline 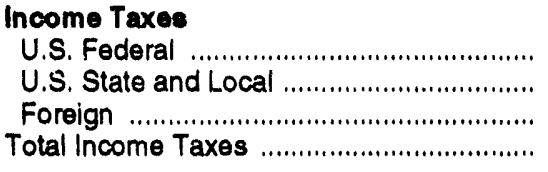 & $\begin{array}{r}1.5 \\
0.6 \\
8.5 \\
10.6\end{array}$ & $\begin{array}{l}0.4 \\
0.8 \\
7.4 \\
8.6\end{array}$ & $\begin{array}{r}-71.1 \\
24.4 \\
-12.7 \\
-18.8\end{array}$ & $\begin{array}{r}6.0 \\
2.5 \\
33.8 \\
42.3\end{array}$ & $\begin{array}{r}1.9 \\
3.5 \\
32.9 \\
38.3\end{array}$ \\
\hline 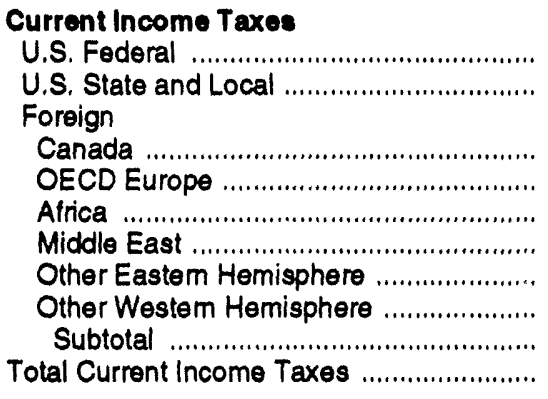 & $\begin{array}{r}0.1 \\
2.7 \\
1.6 \\
1.1 \\
2.2 \\
0.4 \\
8.1 \\
12.7\end{array}$ & $\begin{array}{r}0.6 \\
2.1 \\
1.5 \\
1.3 \\
2.2 \\
0.4 \\
8.0 \\
11.5\end{array}$ & $\begin{array}{r}368.9 \\
-23.8 \\
-3.5 \\
17.2 \\
-3.0 \\
10.5 \\
-1.2 \\
-9.2\end{array}$ & $\begin{array}{r}0.5 \\
10.8 \\
6.2 \\
4.3 \\
8.9 \\
1.5 \\
32.3 \\
50.6\end{array}$ & $\begin{array}{r}12.3 \\
3.4 \\
\\
2.5 \\
9.2 \\
6.7 \\
5.7 \\
9.7 \\
1.9 \\
35.5 \\
51.2\end{array}$ \\
\hline 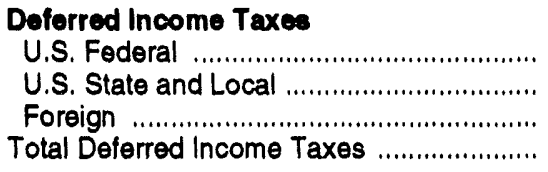 & $\begin{array}{r}-2.4 \\
-0.1 \\
0.4 \\
-2.1\end{array}$ & $\begin{array}{r}-2.3 \\
0.0 \\
-0.6 \\
-2.9\end{array}$ & $\begin{array}{l}-3.0 \\
\left(\begin{array}{l}2 \\
2\end{array}\right) \\
\left(\begin{array}{l}39.2 \\
3\end{array}\right.\end{array}$ & $\begin{array}{r}-9.6 \\
-0.3 \\
1.5 \\
-8.3\end{array}$ & $\begin{array}{r}-10.3 \\
0.1 \\
-2.6 \\
-12.9\end{array}$ \\
\hline
\end{tabular}

1 Excludes discontinued operations, extraordinary items, and cumulative effect of accounting changes.

2 Not meaningful.

Source: Energy Information Administration, Form ElA-28. 
Table B18. U.S. Federal Income Taxes for FRS Companies, 1991 and 1992

\begin{tabular}{|c|c|c|c|c|c|}
\hline \multirow{2}{*}{ U.S. Tax Determination } & \multicolumn{2}{|c|}{ Billion Dollars } & \multirow{2}{*}{$\begin{array}{l}\text { Percent Change } \\
\text { from } 1991\end{array}$} & \multicolumn{2}{|c|}{$\begin{array}{c}\text { Percent of Net Income } \\
\text { Before Taxes }\end{array}$} \\
\hline & 1991 & 1992 & & 1991 & 1992 \\
\hline \multicolumn{6}{|l|}{ Pretax Income 1} \\
\hline 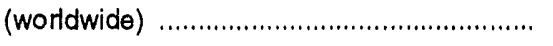 & 25.1 & 22.5 & -10.3 & 100.0 & 100.0 \\
\hline \multicolumn{6}{|l|}{ Adjustments to Income } \\
\hline $\begin{array}{l}\text { Income Not Subject to U.S. Taxes ........... } \\
\text { Deductions for Income }\end{array}$ & -3.7 & -2.8 & -25.0 & -14.6 & -12.2 \\
\hline Taxes Paid in Other Jurisdictions ............. & -1.7 & -1.9 & 12.3 & -6.6 & -8.3 \\
\hline 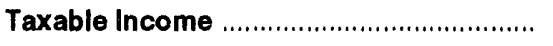 & 19.8 & 17.9 & 9.4 & 78.8 & 79.5 \\
\hline \multicolumn{6}{|l|}{ Expected Tax Computed at U.S. } \\
\hline 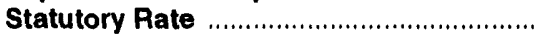 & 6.7 & 6.1 & -9.5 & 26.7 & 27.0 \\
\hline \multicolumn{6}{|l|}{ Cause of Increase or Decrease In Taxes } \\
\hline Statutory Depletion ................................ & -0.1 & -0.1 & -23.3 & -0.3 & -0.3 \\
\hline 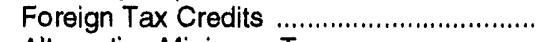 & -5.3 & -4.6 & -12.7 & -21.0 & -20.4 \\
\hline Altemative Minimum Tax ....................... & 0.0 & -0.1 & $(2)$ & 0.0 & -0.4 \\
\hline Investment Tax Credits ............................ & -0.1 & -0.1 & 23.9 & J.3 & -0.4 \\
\hline 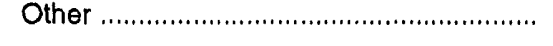 & 0.1 & -0.8 & $\left({ }^{2}\right)$ & 0.3 & -3.7 \\
\hline \multicolumn{6}{|l|}{ U.S. Federal Income Tax Expense on } \\
\hline U.S. Taxable Income .............................. & 1.4 & 0.4 & -69.4 & 5.5 & 1.9 \\
\hline 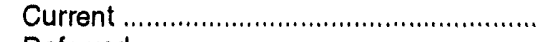 & 3.9 & 2.8 & -29.2 & 15.5 & 12.3 \\
\hline 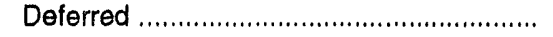 & -2.4 & -2.3 & -3.0 & -9.6 & -10.3 \\
\hline
\end{tabular}

1 Excludes discontinued operations, extraordinary items, and cumulative effect of accounting changes.

2 Not meaningful.

Source: Energy Information Administration, Form ElA-28. 
Table B19. Analysis of Income Taxes for FRS Companies, 1986-1992

(Million Dollars)

\begin{tabular}{|c|c|c|c|c|c|c|c|}
\hline Income Taxes & 1986 & 1987 & 1888 & 1889 & 1990 & 1991 & 1992 \\
\hline 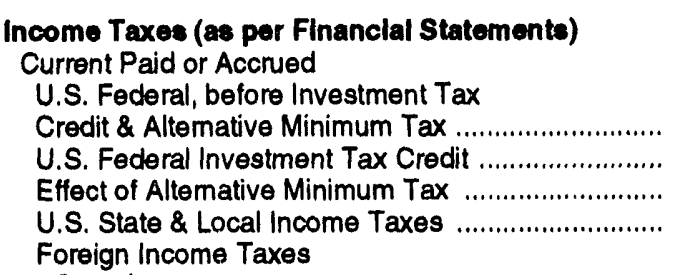 & $\begin{array}{r}-526 \\
-749 \\
0 \\
387\end{array}$ & $\begin{array}{r}4,099 \\
-365 \\
40 \\
694\end{array}$ & $\begin{array}{r}4,283 \\
-449 \\
174 \\
901\end{array}$ & $\begin{array}{r}4,071 \\
-48 \\
24 \\
1,068\end{array}$ & $\begin{array}{r}5,008 \\
-75 \\
534 \\
901\end{array}$ & $\begin{array}{r}3,543 \\
-52 \\
412 \\
695\end{array}$ & $\begin{array}{r}2,355 \\
-41 \\
450 \\
759\end{array}$ \\
\hline 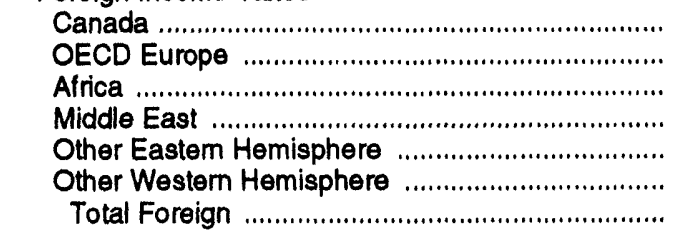 & $\begin{array}{r}654 \\
2,988 \\
1,392 \\
734 \\
1,204 \\
628 \\
7,600\end{array}$ & $\begin{array}{r}890 \\
3,083 \\
1,479 \\
1,099 \\
1,287 \\
703 \\
8,541\end{array}$ & $\begin{array}{r}501 \\
2,840 \\
1,176 \\
670 \\
1,421 \\
700 \\
7,308\end{array}$ & $\begin{array}{r}700 \\
2,261 \\
1,620 \\
997 \\
1,483 \\
620 \\
7,681\end{array}$ & $\begin{array}{r}901 \\
2,864 \\
2,110 \\
1,310 \\
2,261 \\
862 \\
10,308\end{array}$ & $\begin{array}{r}119 \\
2,710 \\
1,563 \\
1,088 \\
2,248 \\
380 \\
8,108\end{array}$ & $\begin{array}{r}558 \\
2,066 \\
1,509 \\
1,275 \\
2,180 \\
420 \\
8,008\end{array}$ \\
\hline Total Current & 6,712 & 13,009 & 12,217 & 12,796 & 16,676 & 12,706 & 11,531 \\
\hline 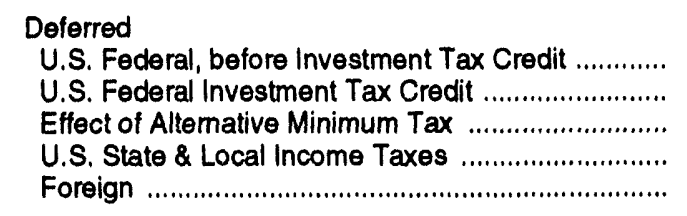 & $\begin{array}{r}2,423 \\
201 \\
0 \\
137 \\
1,046\end{array}$ & $\begin{array}{r}474 \\
188 \\
-31 \\
23 \\
114\end{array}$ & $\begin{array}{r}1,260 \\
405 \\
-173 \\
-54 \\
-159\end{array}$ & $\begin{array}{r}45 \\
23 \\
-13 \\
-30 \\
192\end{array}$ & $\begin{array}{r}420 \\
55 \\
-474 \\
24 \\
-178\end{array}$ & $\begin{array}{r}-1,846 \\
2 \\
-558 \\
-69 \\
385\end{array}$ & $\begin{array}{r}-1,723 \\
-43 \\
-564 \\
20 \\
-594\end{array}$ \\
\hline 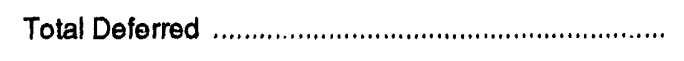 & 3,806 & 768 & 1,279 & 217 & $\cdot 153$ & $-2,086$ & $-2,904$ \\
\hline 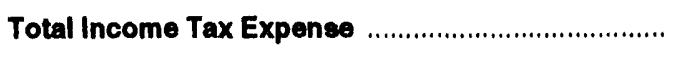 & 10,518 & 13,777 & 13,496 & 13,013 & 16,523 & 10,620 & 8,627 \\
\hline $\begin{array}{l}\text { Reconcillation of Accrued U.S. Federal Income } \\
\text { Tax Expense To Statutory Rate } \\
\text { Consolidated Pretax Income/(Loss) ........................... }\end{array}$ & 20,564 & 25,006 & 34,285 & 32,281 & 37,489 & 25,120 & 22,542 \\
\hline 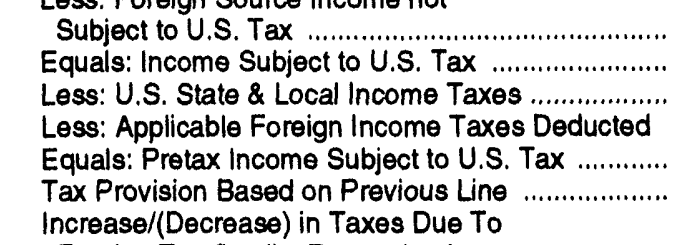 & $\begin{array}{r}4,768 \\
15,796 \\
617 \\
425 \\
14,754 \\
6,787\end{array}$ & $\begin{array}{r}3,670 \\
21,336 \\
717 \\
475 \\
20,144 \\
8,145\end{array}$ & $\begin{array}{r}3,830 \\
30,455 \\
841 \\
578 \\
29,036 \\
9,873\end{array}$ & $\begin{array}{r}4,036 \\
28,245 \\
1,023 \\
663 \\
26,559 \\
9,030\end{array}$ & $\begin{array}{r}3,836 \\
33,653 \\
634 \\
1,174 \\
31,845 \\
10,821\end{array}$ & $\begin{array}{r}3,671 \\
21,449 \\
757 \\
907 \\
19,785 \\
6,717\end{array}$ & $\begin{array}{r}2,753 \\
19,789 \\
748 \\
1,121 \\
17,020 \\
6,082\end{array}$ \\
\hline 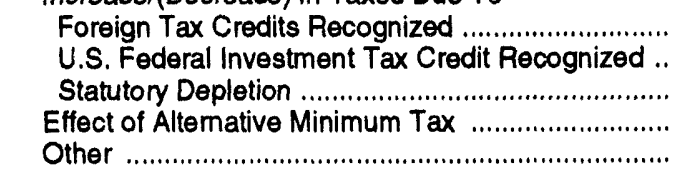 & $\begin{array}{r}-7,046 \\
-618 \\
-130 \\
0 \\
2,355\end{array}$ & $\begin{array}{r}-5,454 \\
-177 \\
-115 \\
10 \\
1,997\end{array}$ & $\begin{array}{r}-4,763 \\
-145 \\
-111 \\
1 \\
642\end{array}$ & $\begin{array}{r}-5,014 \\
-26 \\
-114 \\
10 \\
216\end{array}$ & $\begin{array}{r}-6,031 \\
-42 \\
-116 \\
34 \\
802\end{array}$ & $\begin{array}{r}-5,263 \\
-67 \\
-86 \\
-3 \\
87\end{array}$ & $\begin{array}{r}-4,596 \\
-83 \\
-66 \\
-87 \\
-826\end{array}$ \\
\hline Actual U.S. Federal Tax Provision (Refund) ............ & 1,348 & 4.406 & 5,497 & 4,102 & 5,468 & 1,385 & 424 \\
\hline
\end{tabular}

Source: Energy Information Administration, Form ElA-28. 
Table B20. U.S. Taxes Other Than Income Taxes for FRS Companies, 1992 and Percent Change from 1991

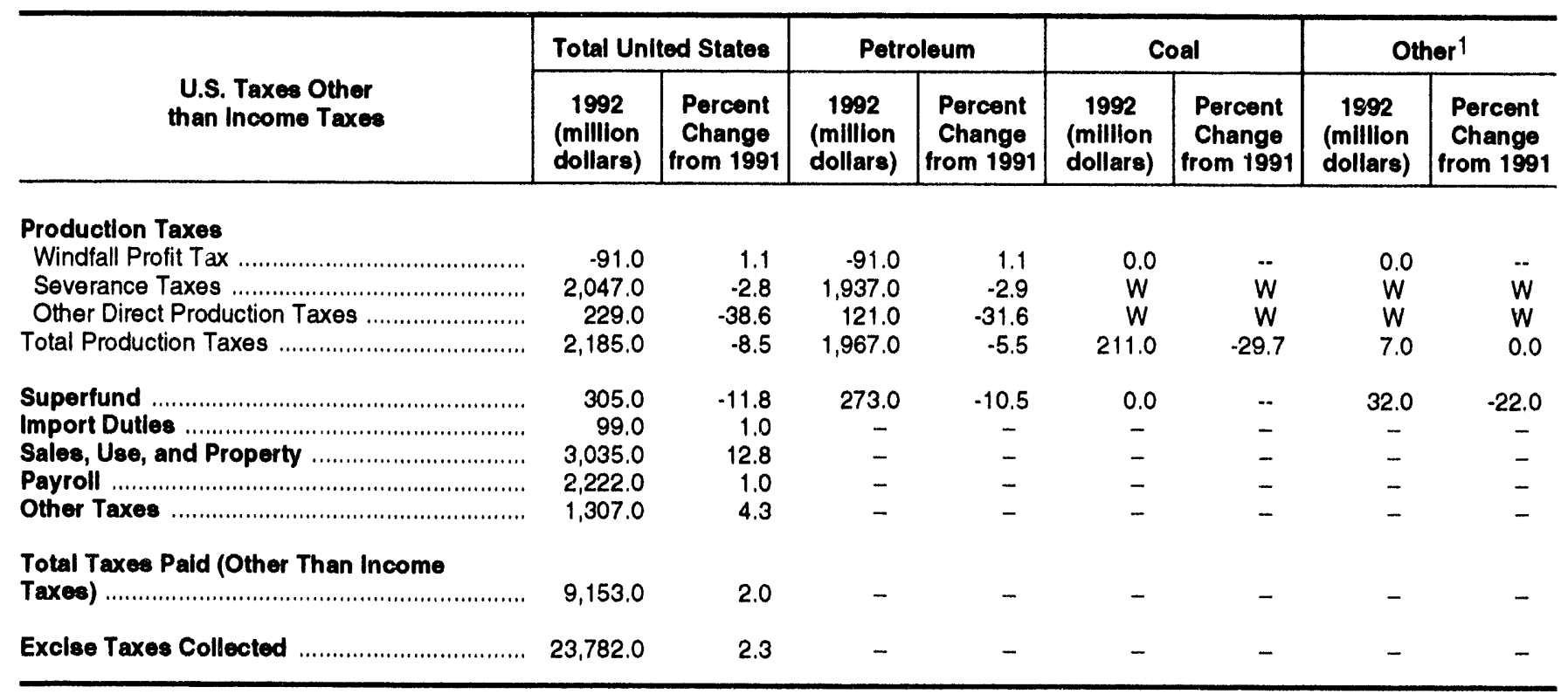

\footnotetext{
Nuclear, Other Energy, and Nonenergy.

$\bar{W}=$ Not available.

$W=$ Data withheld to avoid disclosure.

- = Not applicable.

Source: Energy Information Administration, Form ElA-28.
} 
Table B21. Petroleum Exploration and Development Expenditures for FRS Companies, United States and Foreign, 1992 and Percent Change from 1991

\begin{tabular}{|c|c|c|c|c|c|c|c|}
\hline \multirow[b]{2}{*}{$\begin{array}{l}\text { Exploration } \\
\text { and } \\
\text { Development } \\
\text { Expenditures }\end{array}$} & \multirow{2}{*}{\begin{tabular}{|c|}
$\begin{array}{c}\text { Worldwide } \\
\text { Expendltures }\end{array}$ \\
$\begin{array}{c}\text { FRS } \\
\text { Companies } \\
\text { (million } \\
\text { dollars) } \\
1992\end{array}$ \\
\end{tabular}} & \multicolumn{3}{|c|}{ U.S. Expenditures } & \multicolumn{3}{|c|}{ Forelgn Expenditures } \\
\hline & & $\begin{array}{c}\text { FRS } \\
\text { Companies } \\
\text { (million } \\
\text { dollars) } \\
1992\end{array}$ & $\begin{array}{c}\text { Percent } \\
\text { Change } \\
\text { from } 1991\end{array}$ & $\begin{array}{c}\text { U.S. FRS } \\
\text { as a Percent } \\
\text { of Total FRS } \\
1992\end{array}$ & $\begin{array}{c}\text { FRS } \\
\text { Companies } \\
\text { (million } \\
\text { dollars) } \\
1992\end{array}$ & $\begin{array}{l}\text { Percent } \\
\text { Change } \\
\text { from } 1991\end{array}$ & $\begin{array}{c}\text { FRS Forelgn } \\
\text { as a Porcent } \\
\text { of Total FRS } \\
1992\end{array}$ \\
\hline \multicolumn{8}{|l|}{ Exploration } \\
\hline Acquisition of Unproved Acreage ........ & 432.0 & 257.0 & -54.8 & 59.5 & 175.0 & -49.9 & 40.5 \\
\hline Goological and Geophysical .............. & $1,602.0$ & 475.0 & -26.7 & 29.7 & $1,127.0$ & -1.3 & 70.3 \\
\hline Drilling and Equipping & $2,803.0$ & $1,185.0$ & -40.8 & 42.3 & $1,618.0$ & -38.7 & 57.7 \\
\hline Other & $1,881.0$ & 758.0 & -27.9 & 40.3 & $1,123.0$ & -0.1 & 59.7 \\
\hline 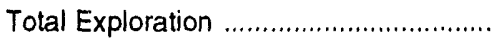 & $6,718.0$ & $2,675.0$ & -37.3 & 39.8 & $4,043.0$ & -23.0 & 60.2 \\
\hline \multicolumn{8}{|l|}{ Development } \\
\hline Acquisition of Proved Acreage ............ & 684.0 & 541.0 & -52.4 & 79.1 & 143.0 & -20.1 & 20.9 \\
\hline Lease Equipment ................................ & $3,832.0$ & $1,450.0$ & -34.5 & 37.8 & $2,382.0$ & 14.8 & 62.2 \\
\hline 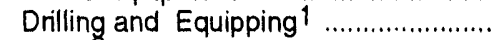 & $7,329.0$ & $3,487.0$ & -18.0 & 47.6 & $3,842.0$ & 0.5 & 52.4 \\
\hline Other ${ }^{2}$ & $4,660.0$ & $2,161.0$ & -7.4 & 46.4 & $2,499.0$ & 5.2 & 53.6 \\
\hline 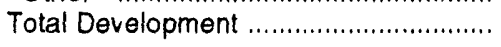 & $16,505.0$ & $7,639.0$ & -23.1 & 46.3 & $8,866.0$ & 4.9 & 53.7 \\
\hline Total Exploration and Development . & $23,223.0$ & $10,314.0$ & -27.4 & 44.4 & $12,909.0$ & -5.8 & 55.6 \\
\hline
\end{tabular}

1 Expenditure incurred in a given year not cumulative (includes work in progress adjustment).

2 Includes support equipment.

Source: Energy Information Administration, Form EIA-28. 
Table B22. U.S. and Foreign Exploration and Development Expenditures and Production (Lifting) Costs for FRS Companies, 1992

(Million Dollars)

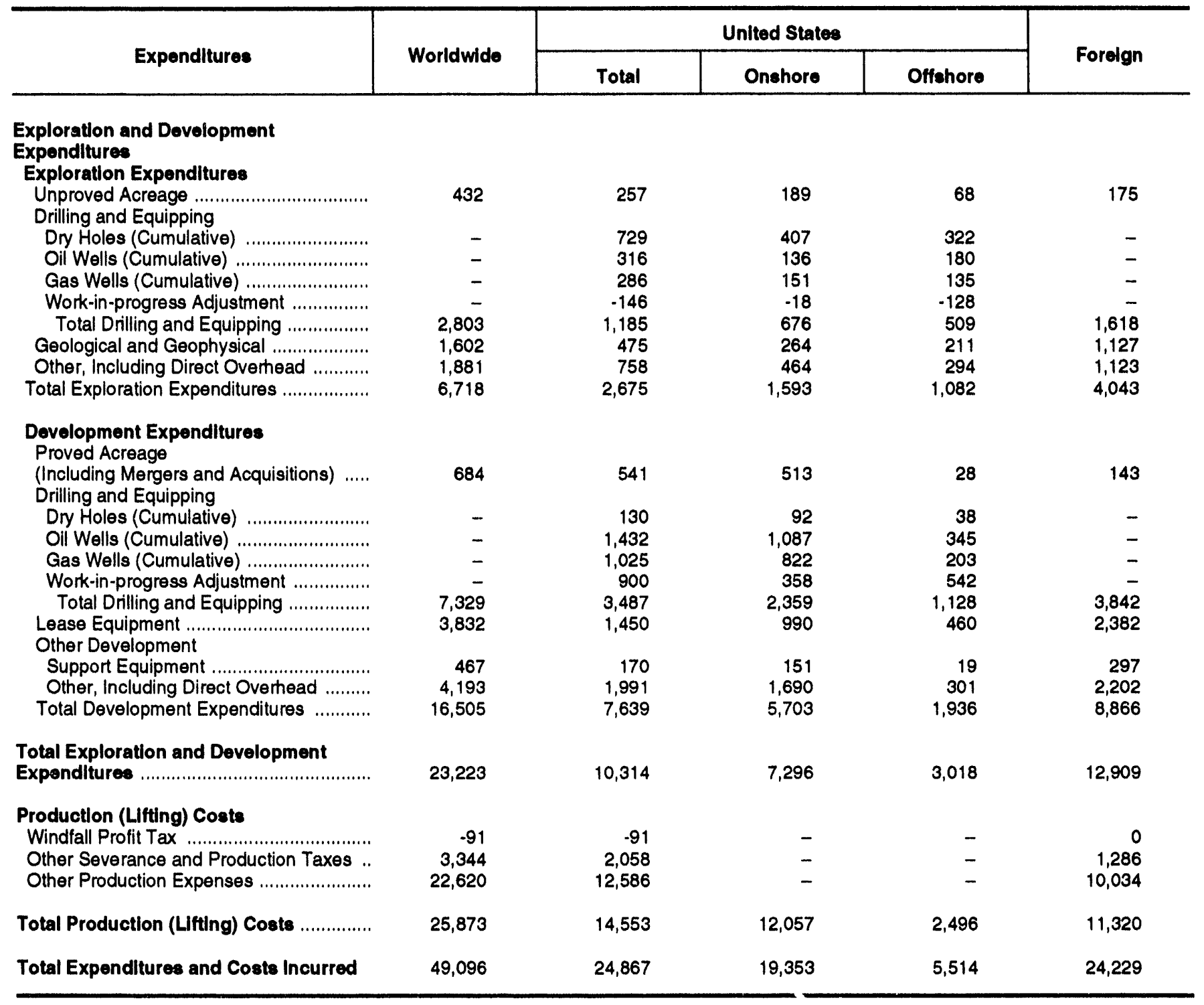

- = Not available.

Source: Energy Information Administration, Form ElA-28. 
Table B23. Total Exploratory and Development Wells Drilled in the United States for FRS Companies and U.S. Industry, 1991 and 1992

\begin{tabular}{|c|c|c|c|c|c|c|}
\hline \multirow{2}{*}{ Wells Drilled } & \multicolumn{2}{|c|}{ U.S. Induetry } & \multicolumn{2}{|c|}{ FRS } & \multicolumn{2}{|c|}{ All Other } \\
\hline & 1991 & 1992 & 1991 & 1992 & 1991 & 1992 \\
\hline 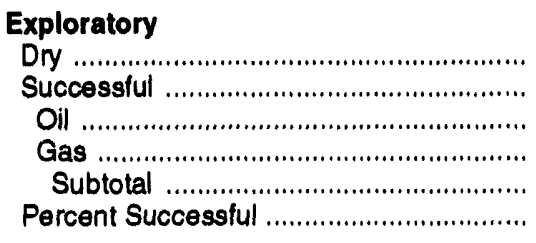 & $\begin{array}{r}3,340 \\
1,045 \\
564 \\
481 \\
4,386 \\
23,8\end{array}$ & $\begin{array}{r}2,509 \\
775 \\
438 \\
337 \\
3,285 \\
23.6\end{array}$ & $\begin{array}{r}390 \\
534 \\
196 \\
338 \\
924 \\
57.8\end{array}$ & $\begin{array}{r}344 \\
283 \\
132 \\
151 \\
627 \\
45.1\end{array}$ & $\begin{array}{r}2,950 \\
511 \\
368 \\
143 \\
3,461 \\
14.8\end{array}$ & $\begin{array}{r}2,165 \\
492 \\
306 \\
186 \\
2,657 \\
18.5\end{array}$ \\
\hline 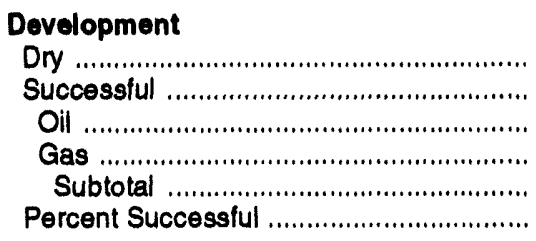 & $\begin{array}{r}4,462 \\
19,984 \\
11,314 \\
8,670 \\
24,446 \\
81.7\end{array}$ & $\begin{array}{r}3,872 \\
15,578 \\
8,188 \\
7,390 \\
19,451 \\
80.1\end{array}$ & $\begin{array}{r}345 \\
4,301 \\
2,866 \\
1,435 \\
4,646 \\
92.6\end{array}$ & $\begin{array}{r}212 \\
3,403 \\
1,775 \\
1,628 \\
3,615 \\
94.1\end{array}$ & $\begin{array}{r}4,117 \\
15,683 \\
8,448 \\
7,235 \\
19,800 \\
79.2\end{array}$ & $\begin{array}{r}3,660 \\
12,175 \\
6,413 \\
5,762 \\
15,836 \\
76.8\end{array}$ \\
\hline 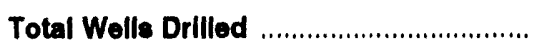 & 28,832 & 22,735 & 5,570 & 4,242 & 23,262 & 18,493 \\
\hline
\end{tabular}

Note: Sum of components may not equal total due to independent rounding.

Sources: Industry data - Special compilation provided by the Office of Oil and Gas, Energy Information Administration. Totals are based on data which appeared in the Energy Information Administration's Monthly Energy Review, September 1993, p. 87. FRS companies data - Energy Information Administration, Form ElA-28. 
Table B24. Completed Well Costs, Oi!, Gas, and Dry, for FRS Companies and U.S. Industry, 1991 and 1992

\begin{tabular}{|c|c|c|c|c|c|c|c|c|}
\hline \multirow{2}{*}{$\begin{array}{c}\text { Drllling } \\
\text { and } \\
\text { Equipping Measures }\end{array}$} & \multicolumn{3}{|c|}{ FRS Companies } & \multicolumn{3}{|c|}{ U.S. Industry } & \multicolumn{2}{|c|}{$\begin{array}{c}\text { FRS as a Percent of } \\
\text { U.S. Industry }\end{array}$} \\
\hline & 1991 & 1992 & $\begin{array}{l}\text { Percent } \\
\text { Change }\end{array}$ & 1991 & 1992 & $\begin{array}{l}\text { Percent } \\
\text { Change }\end{array}$ & 1991 & 1992 \\
\hline
\end{tabular}

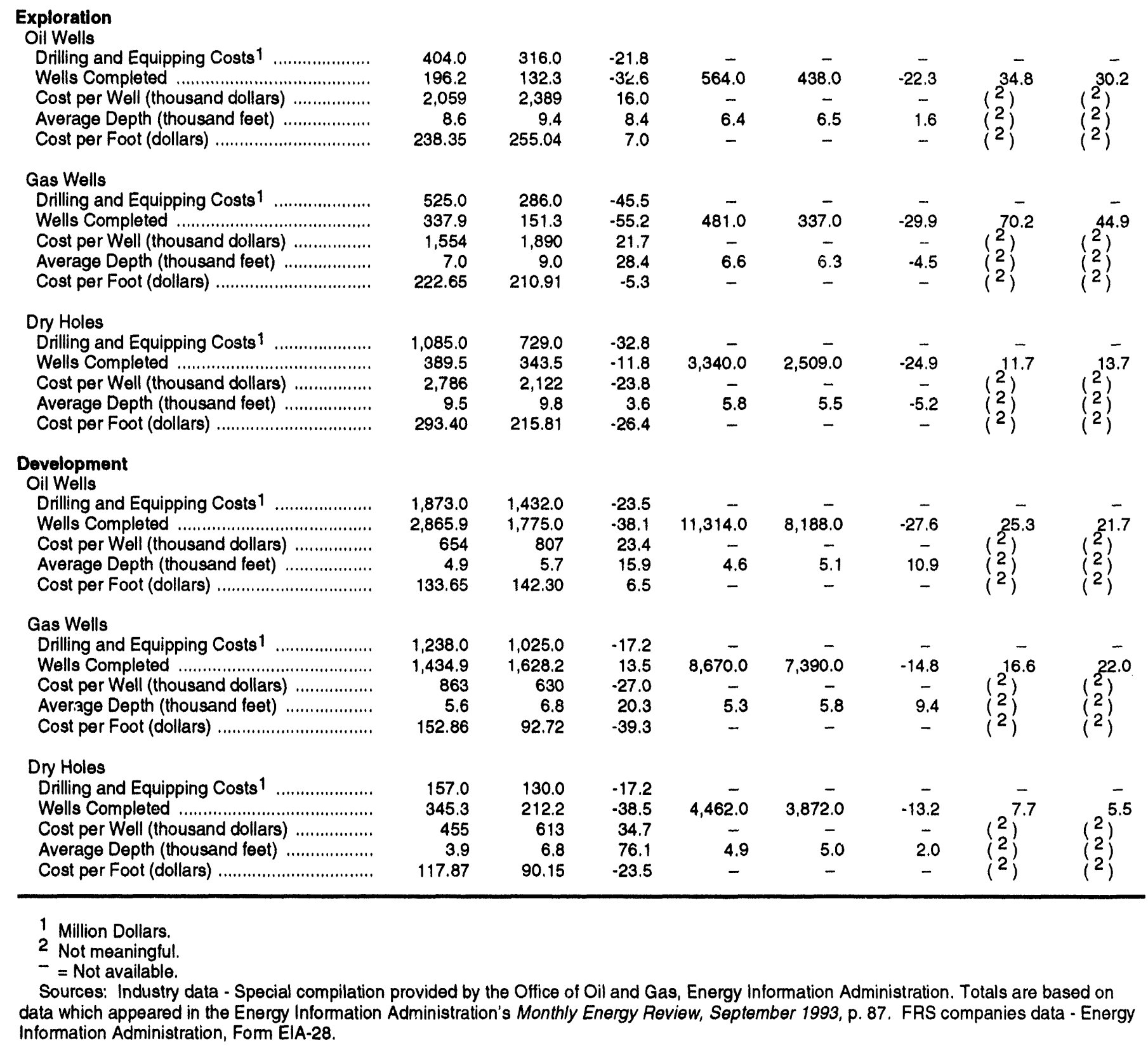


Table B25. Completed Well Costs, Oil, Gas, and Dry, Onshore and Offshore, for FRS Companies, 1991 and 1992

\begin{tabular}{|c|c|c|c|c|c|c|c|c|c|}
\hline \multirow{2}{*}{$\begin{array}{c}\text { Drilling } \\
\text { and } \\
\text { Equipping Measures }\end{array}$} & \multicolumn{3}{|c|}{ Total United States } & \multicolumn{3}{|c|}{ U.S. Onshore } & \multicolumn{3}{|c|}{ U.S. Offshore } \\
\hline & 1991 & 1992 & $\begin{array}{l}\text { Percent } \\
\text { Change }\end{array}$ & 1991 & 1992 & $\begin{array}{l}\text { Percent } \\
\text { Change }\end{array}$ & 1991 & 1992 & $\begin{array}{l}\text { Percent } \\
\text { Change }\end{array}$ \\
\hline \multicolumn{10}{|l|}{ Exploration } \\
\hline Drilling and Equipping Costs 1 ......... & 404.0 & 316.0 & -21.8 & 175.0 & 136.0 & -22.3 & 229.0 & 180.0 & -21.4 \\
\hline 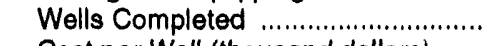 & 196.2 & 132.3 & -32.6 & 155.1 & 111.8 & -27.9 & 41.1 & 20.5 & -50.1 \\
\hline Cost per Well (thousand dcllars) ..... & 2,059 & 2,389 & 16.0 & 1,128 & 1,216 & 7.8 & 5,572 & 8,780 & 57.6 \\
\hline Average Depth (thousand feet) ....... & 8.6 & 9.4 & 8.4 & 7.8 & 8.6 & 10.7 & 11.8 & 13.4 & 13.2 \\
\hline Cost per Foot (dollars) ....................... & 238.35 & 255.04 & 7.0 & 144.87 & 141.08 & -2.6 & 470.23 & 654.55 & 39.2 \\
\hline \multicolumn{10}{|l|}{ Gas Wells } \\
\hline Drilling and Equipping Costs 1 ........ & 525.0 & 286.0 & -45.5 & 275.0 & 151.0 & -45.1 & 250.0 & 135.0 & -46.0 \\
\hline 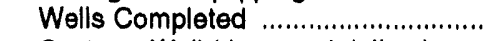 & 337.9 & 151.3 & -55.2 & 282.9 & 126.7 & -55.2 & 55.0 & 24.6 & -55.3 \\
\hline Cost per Well (thousand dollars) ..... & 1,554 & 1,890 & 21.7 & 972 & 1,192 & 22.6 & 4,545 & 5,488 & 20.7 \\
\hline Average Depth (thousand feet) ....... & 7.0 & 9.0 & 28.4 & 6.0 & 8.2 & 35.1 & 11.8 & 13.0 & 10.9 \\
\hline 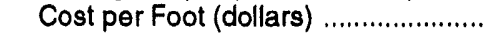 & 222.65 & 210.91 & -5.3 & 160.72 & 145.89 & -9.2 & 386.40 & 420.56 & 8.8 \\
\hline \multicolumn{10}{|l|}{ Dry Holes } \\
\hline Drilling and Equipping Costs 1 ......... & $1,085.0$ & 729.0 & -32.8 & 428.0 & 407.0 & -4.9 & 657.0 & 322.0 & -51.0 \\
\hline Wells Completed .............................. & 389.5 & 343.5 & -11.8 & 297.1 & 294.0 & -1.0 & 92.4 & 49.5 & -46.4 \\
\hline Cost per Well (thousand dollars) ..... & 2,786 & 2,122 & -23.8 & 1,441 & 1,384 & -3.9 & 7,110 & 6,505 & -8.5 \\
\hline Average Depth (thousand feet) ........ & $\begin{array}{r}9.5 \\
20301\end{array}$ & $\begin{array}{r}9.8 \\
21581\end{array}$ & 3.6 & $\begin{array}{r}8.8 \\
16302\end{array}$ & $\begin{array}{r}8.9 \\
155.17\end{array}$ & $\begin{array}{r}1.5 \\
-53\end{array}$ & $\begin{array}{r}11.8 \\
604.62\end{array}$ & $\begin{array}{r}15.3 \\
296.49\end{array}$ & 29.6 \\
\hline Cost per Foot (dollars) ...................... & 293.40 & 215.81 & -26.4 & 163.92 & 155.17 & -5.3 & 604.42 & 426.49 & -29.4 \\
\hline \multicolumn{10}{|l|}{$\begin{array}{l}\text { Development } \\
\text { Oil Wells }\end{array}$} \\
\hline Drilling and Equipping Costs 1 ......... & $1,873.0$ & $1,432.0$ & -23.5 & $1,472.0$ & $1,087.0$ & -26.2 & 401.0 & 345.0 & -14.0 \\
\hline 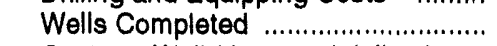 & $2,865.9$ & $1,775.0$ & -38.1 & $2,738.4$ & $1,664.1$ & -39.2 & 127.5 & 110.9 & -13.0 \\
\hline Cost per Well (thousand dollars) ..... & 654 & 807 & 23.4 & 538 & 653 & 21.5 & 3,145 & 3,111 & -1.1 \\
\hline Average Depth (thousand feet) ....... & 4.9 & 5.7 & 15.9 & 4.7 & 5.5 & 17.0 & 8.5 & 7.9 & -7.8 \\
\hline Cost per Foot (dollars) ...................... & 133.65 & 142.30 & 6.5 & 113.86 & 118.26 & 3.9 & 369.24 & 396.10 & 7.3 \\
\hline \multicolumn{10}{|l|}{ Gas Wells } \\
\hline Drilling and Equipping Costs 1 ......... & $1,238.0$ & $1,025.0$ & -17.2 & 930.0 & 822.0 & -11.6 & 308.0 & 203.0 & -34.1 \\
\hline Wells Completed ............................... & $1,434.9$ & $1,628.2$ & 13.5 & $1,354.3$ & $1,582.3$ & 16.8 & 80.6 & 45.9 & -43.1 \\
\hline Cost per Well (thousand dollars) ..... & 863 & 630 & -27.0 & 687 & 519 & -24.3 & 3,821 & 4,423 & 15.7 \\
\hline Average Depth (thousand feet) ........ & 5.6 & 6.8 & 20.3 & 5.5 & 6.7 & 22.7 & 8.8 & 10.2 & 15.1 \\
\hline 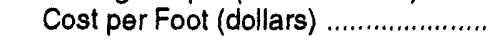 & 152.86 & 92.72 & -39.3 & 125.88 & 77.63 & -38.3 & 433.19 & 435.62 & 0.6 \\
\hline \multicolumn{10}{|l|}{ Dry Holes } \\
\hline Drilling and Equipping Costs 1 ......... & 157.0 & 130.0 & -17.2 & 110.0 & 92.0 & -16.4 & 47.0 & 38.0 & -19.1 \\
\hline 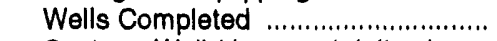 & 345.3 & 212.2 & -38.5 & 325.7 & 193.0 & -40.7 & 19.6 & 19.2 & -2.0 \\
\hline Cost per Well (thousand dollars) ..... & 455 & 613 & 34.7 & 338 & 477 & 41.1 & 2,398 & 1,979 & -17.5 \\
\hline Average Depth (thousand feet) ....... & 3.9 & 6.8 & 76.2 & 3.5 & 6.6 & 89.7 & 10.3 & 9.0 & -13.1 \\
\hline Cost per Foot (dollars) ...................... & 117.87 & 90.15 & -23.5 & 97.35 & 72.44 & -25.6 & 232.67 & 220.93 & -5.0 \\
\hline
\end{tabular}

1 Million Dollars.

Source: Energy Information Administration, Form ElA-28. 
Table B26. U.S. Net Wells Completed, and Net In-Progress Wells for FRS Companies, 1986-1992

\begin{tabular}{|c|c|c|c|c|c|c|c|}
\hline Wells & 1986 & 1987 & 1988 & 1989 & 1990 & 1991 & 1992 \\
\hline \multicolumn{8}{|l|}{$\begin{array}{l}\text { Number of Net Wells Completed } \\
\text { During Year } \\
\text { Onshore } \\
\text { Net Exploratory Wells }\end{array}$} \\
\hline 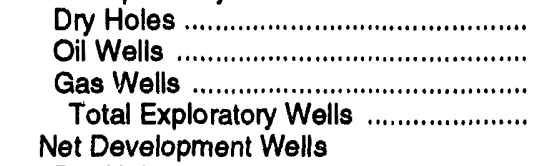 & $\begin{array}{r}655 \\
282 \\
153 \\
1,089\end{array}$ & $\begin{array}{l}498 \\
253 \\
127 \\
877\end{array}$ & $\begin{array}{l}574 \\
164 \\
202 \\
940\end{array}$ & $\begin{array}{l}395 \\
105 \\
270 \\
769\end{array}$ & $\begin{array}{r}411 \\
132 \\
490 \\
1,033\end{array}$ & $\begin{array}{l}297 \\
155 \\
283 \\
735\end{array}$ & $\begin{array}{l}294 \\
112 \\
127 \\
533\end{array}$ \\
\hline 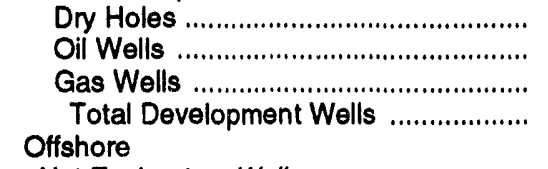 & $\begin{array}{r}493 \\
4,066 \\
645 \\
5,204\end{array}$ & $\begin{array}{r}330 \\
4,096 \\
615 \\
5,040\end{array}$ & $\begin{array}{r}388 \\
3,742 \\
1,022 \\
5,153\end{array}$ & $\begin{array}{r}299 \\
2,604 \\
1,161 \\
4,064\end{array}$ & $\begin{array}{r}260 \\
3,337 \\
1,681 \\
5,277\end{array}$ & $\begin{array}{r}326 \\
2,738 \\
1,354 \\
4,418\end{array}$ & $\begin{array}{r}193 \\
1,664 \\
1,582 \\
3,439\end{array}$ \\
\hline 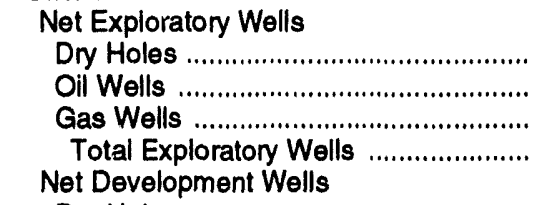 & $\begin{array}{r}159 \\
34 \\
47 \\
240\end{array}$ & $\begin{array}{r}109 \\
23 \\
40 \\
172\end{array}$ & $\begin{array}{r}164 \\
34 \\
66 \\
264\end{array}$ & $\begin{array}{r}100 \\
27 \\
61 \\
189\end{array}$ & $\begin{array}{r}114 \\
31 \\
76 \\
222\end{array}$ & $\begin{array}{r}92 \\
41 \\
55 \\
189\end{array}$ & $\begin{array}{l}50 \\
21 \\
25 \\
95\end{array}$ \\
\hline 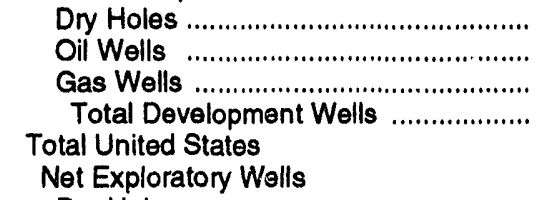 & $\begin{array}{r}43 \\
243 \\
93 \\
375\end{array}$ & $\begin{array}{r}29 \\
163 \\
60 \\
252\end{array}$ & $\begin{array}{r}33 \\
161 \\
83 \\
277\end{array}$ & $\begin{array}{r}31 \\
161 \\
92 \\
285\end{array}$ & $\begin{array}{r}32 \\
143 \\
146 \\
321\end{array}$ & $\begin{array}{r}20 \\
128 \\
81 \\
228\end{array}$ & $\begin{array}{r}19 \\
111 \\
46 \\
176\end{array}$ \\
\hline 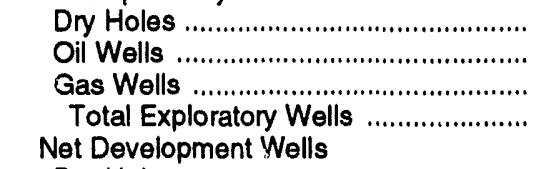 & $\begin{array}{r}814 \\
316 \\
200 \\
1,330\end{array}$ & $\begin{array}{r}606 \\
276 \\
166 \\
1,049\end{array}$ & $\begin{array}{r}738 \\
198 \\
268 \\
1,204\end{array}$ & $\begin{array}{l}495 \\
132 \\
331 \\
958\end{array}$ & $\begin{array}{r}525 \\
163 \\
566 \\
1,254\end{array}$ & $\begin{array}{l}390 \\
196 \\
338 \\
924\end{array}$ & $\begin{array}{l}344 \\
132 \\
151 \\
627\end{array}$ \\
\hline 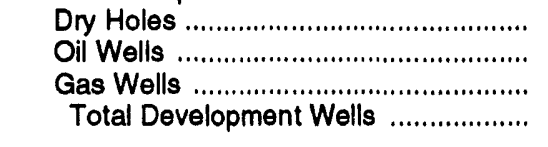 & $\begin{array}{r}537 \\
4,309 \\
738 \\
5,583\end{array}$ & $\begin{array}{r}359 \\
4,259 \\
675 \\
5,293\end{array}$ & $\begin{array}{r}422 \\
3,903 \\
1,105 \\
5,430\end{array}$ & $\begin{array}{r}330 \\
2,765 \\
1,253 \\
4,349\end{array}$ & $\begin{array}{r}293 \\
3,479 \\
1,826 \\
5,598\end{array}$ & $\begin{array}{r}345 \\
2,866 \\
1,435 \\
4,646\end{array}$ & $\begin{array}{r}212 \\
1,775 \\
1,628 \\
3,615\end{array}$ \\
\hline $\begin{array}{l}\text { Number of Net In-Progress Wells } \\
\text { At Year End } \\
\text { Onshore }\end{array}$ & & & & & & & \\
\hline 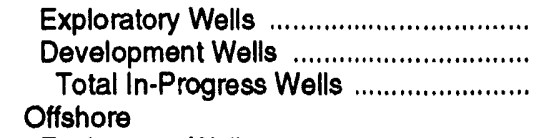 & $\begin{array}{l}170 \\
555 \\
725\end{array}$ & $\begin{array}{r}220 \\
798 \\
1,019\end{array}$ & $\begin{array}{l}152 \\
694 \\
846\end{array}$ & $\begin{array}{r}301 \\
813 \\
1,113\end{array}$ & $\begin{array}{r}275 \\
1,100 \\
1,375\end{array}$ & $\begin{array}{l}125 \\
650 \\
775\end{array}$ & $\begin{array}{r}97 \\
795 \\
892\end{array}$ \\
\hline 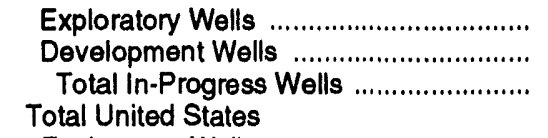 & $\begin{array}{r}88 \\
92 \\
180\end{array}$ & $\begin{array}{l}136 \\
113 \\
249\end{array}$ & $\begin{array}{r}73 \\
128 \\
201\end{array}$ & $\begin{array}{r}62 \\
109 \\
171\end{array}$ & $\begin{array}{r}72 \\
64 \\
137\end{array}$ & $\begin{array}{l}49 \\
36 \\
85\end{array}$ & $\begin{array}{l}39 \\
57 \\
96\end{array}$ \\
\hline 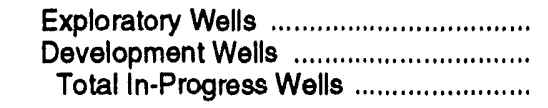 & $\begin{array}{l}258 \\
647 \\
905\end{array}$ & $\begin{array}{r}356 \\
911 \\
1,267\end{array}$ & $\begin{array}{r}224 \\
822 \\
1,047\end{array}$ & $\begin{array}{r}363 \\
922 \\
1,285\end{array}$ & $\begin{array}{r}347 \\
1,164 \\
1,512\end{array}$ & $\begin{array}{l}174 \\
686 \\
860\end{array}$ & $\begin{array}{l}136 \\
852 \\
988\end{array}$ \\
\hline
\end{tabular}

Source: Energy Information Administration, Form ElA-28. 
Table B27. Exploration and Development Net Drilling Footage for FRS Companies, 1986-1992 (Thousand Feet)

\begin{tabular}{|c|c|c|c|c|c|c|c|}
\hline $\begin{array}{l}\text { Exploration, Development, and } \\
\text { Production Statistics }\end{array}$ & 1986 & 1987 & 1988 & 1989 & 1990 & 1991 & 1992 \\
\hline 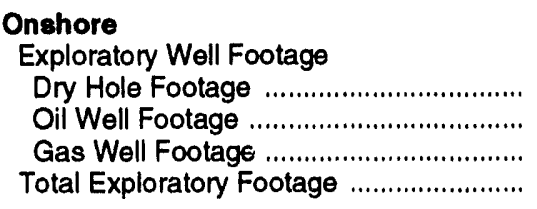 & $\begin{array}{l}6,072 \\
2,440 \\
1,288 \\
9,800\end{array}$ & $\begin{array}{r}4,388 \\
1,988 \\
981 \\
7,357\end{array}$ & $\begin{array}{l}5,014 \\
1,367 \\
1,438 \\
7,819\end{array}$ & $\begin{array}{r}3,143 \\
888 \\
1,520 \\
5,551\end{array}$ & $\begin{array}{l}3,660 \\
1,069 \\
2,126 \\
6,855\end{array}$ & $\begin{array}{l}2,611 \\
1,208 \\
1,711 \\
5,530\end{array}$ & $\begin{array}{r}2,623 \\
964 \\
1,035 \\
4,622\end{array}$ \\
\hline 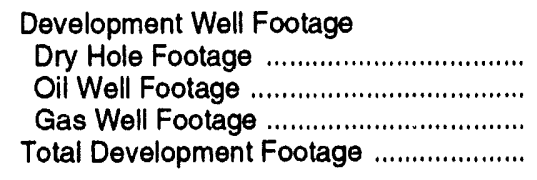 & $\begin{array}{r}3,821 \\
17,784 \\
5,963 \\
27,568\end{array}$ & $\begin{array}{r}2,251 \\
17,036 \\
4,878 \\
24,165\end{array}$ & $\begin{array}{r}2,426 \\
15,909 \\
6,654 \\
24,989\end{array}$ & $\begin{array}{r}1,858 \\
11,289 \\
7,079 \\
20,226\end{array}$ & $\begin{array}{r}1,758 \\
14,442 \\
10,593 \\
26,793\end{array}$ & $\begin{array}{r}1,130 \\
12,928 \\
7,388 \\
21,446\end{array}$ & $\begin{array}{r}1,270 \\
9,192 \\
10,589 \\
21,051\end{array}$ \\
\hline 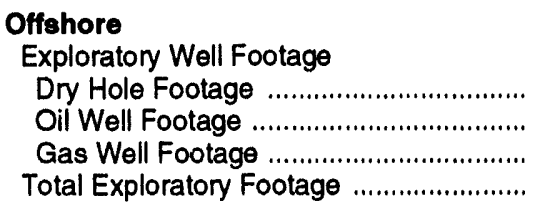 & $\begin{array}{r}1,827 \\
396 \\
570 \\
2,793\end{array}$ & $\begin{array}{r}1,303 \\
252 \\
511 \\
2,066\end{array}$ & $\begin{array}{r}1,847 \\
342 \\
771 \\
2,960\end{array}$ & $\begin{array}{r}1,086 \\
285 \\
694 \\
2,065\end{array}$ & $\begin{array}{r}1,268 \\
400 \\
809 \\
2,477\end{array}$ & $\begin{array}{r}1,087 \\
487 \\
647 \\
2,221\end{array}$ & $\begin{array}{r}755 \\
275 \\
321 \\
1,351\end{array}$ \\
\hline 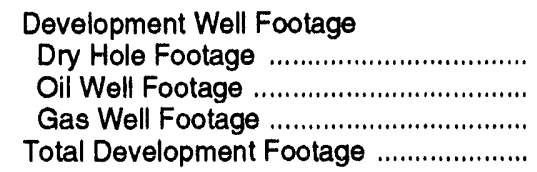 & $\begin{array}{r}439 \\
2,532 \\
905 \\
3,876\end{array}$ & $\begin{array}{r}291 \\
1,690 \\
683 \\
2,664\end{array}$ & $\begin{array}{r}295 \\
1,551 \\
892 \\
2,738\end{array}$ & $\begin{array}{r}260 \\
1,521 \\
983 \\
2,764\end{array}$ & $\begin{array}{r}201 \\
1,247 \\
1,074 \\
2,522\end{array}$ & $\begin{array}{r}202 \\
1,086 \\
711 \\
1,999\end{array}$ & $\begin{array}{r}172 \\
871 \\
466 \\
1,509\end{array}$ \\
\hline
\end{tabular}

Source: Energy Information Administration, Form EIA-28. 
Table B28. U.S. Not Producing Wells and U.S. Acreage for FRS Companies, 1986-1992

\begin{tabular}{|c|c|c|c|c|c|c|c|}
\hline Welle and Acronge & 1086 & 1987 & 1888 & 1989 & 1890 & 1991 & 1992 \\
\hline 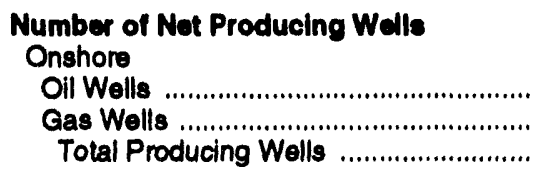 & $\begin{array}{r}178,027 \\
45,721 \\
223,748\end{array}$ & $\begin{array}{r}174,568 \\
43,711 \\
218,279\end{array}$ & $\begin{array}{r}167,018 \\
42,918 \\
209,936\end{array}$ & $\begin{array}{r}143,852 \\
43,088 \\
186,940\end{array}$ & $\begin{array}{r}133,889 \\
43,124 \\
177,013\end{array}$ & $\begin{array}{r}123,426 \\
43,591 \\
167,017\end{array}$ & $\begin{array}{r}112,782 \\
46,308 \\
159,089\end{array}$ \\
\hline 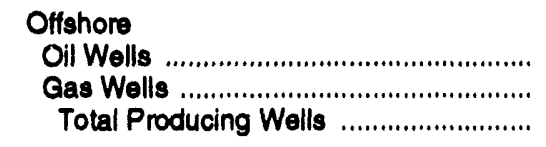 & $\begin{array}{r}7,420 \\
3,342 \\
10,762\end{array}$ & $\begin{array}{r}6,573 \\
3,571 \\
10,144\end{array}$ & $\begin{array}{l}6,377 \\
3,026 \\
9,402\end{array}$ & $\begin{array}{l}5,849 \\
3,205 \\
9,054\end{array}$ & $\begin{array}{l}5,795 \\
3,150 \\
8,944\end{array}$ & $\begin{array}{l}5,337 \\
2,887 \\
8,224\end{array}$ & $\begin{array}{l}5,021 \\
2,709 \\
7,730\end{array}$ \\
\hline 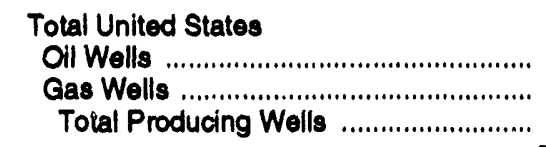 & $\begin{array}{r}185,446 \\
49,063 \\
234,509\end{array}$ & $\begin{array}{r}181,141 \\
47,283 \\
228,424\end{array}$ & $\begin{array}{r}173,395 \\
45,944 \\
219,339\end{array}$ & $\begin{array}{r}149,701 \\
46,293 \\
195,994\end{array}$ & $\begin{array}{r}139,684 \\
46,274 \\
185,958\end{array}$ & $\begin{array}{r}128,763 \\
46,478 \\
175,241\end{array}$ & $\begin{array}{r}117,803 \\
49,016 \\
166,819\end{array}$ \\
\hline & \multicolumn{7}{|c|}{ (thousand acres) } \\
\hline \multicolumn{8}{|l|}{$\begin{array}{l}\text { Net Acreage } \\
\text { Onshore }\end{array}$} \\
\hline 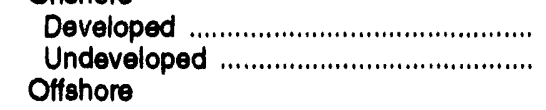 & $\begin{array}{r}33,351 \\
108,227\end{array}$ & $\begin{array}{l}31,208 \\
89,731\end{array}$ & $\begin{array}{l}33,068 \\
80,033\end{array}$ & $\begin{array}{l}32,864 \\
67,898\end{array}$ & $\begin{array}{l}31,345 \\
59,085\end{array}$ & $\begin{array}{l}31,043 \\
53,923\end{array}$ & $\begin{array}{l}29,590 \\
44,433\end{array}$ \\
\hline 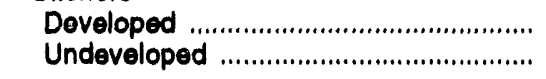 & $\begin{array}{r}4,508 \\
14,520\end{array}$ & $\begin{array}{r}6,296 \\
16,055\end{array}$ & $\begin{array}{r}5,188 \\
19,619\end{array}$ & $\begin{array}{r}5,423 \\
22,010\end{array}$ & $\begin{array}{r}6,089 \\
23,095\end{array}$ & $\begin{array}{r}5,237 \\
22,993\end{array}$ & $\begin{array}{r}5,202 \\
20,837\end{array}$ \\
\hline $\begin{array}{l}\text { Groes Acreage } \\
\text { Onshore }\end{array}$ & & & & & & & \\
\hline 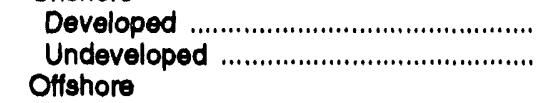 & $\begin{array}{r}70,146 \\
165,582\end{array}$ & $\begin{array}{r}66,280 \\
135,463\end{array}$ & $\begin{array}{r}64,801 \\
117,028\end{array}$ & $\begin{array}{r}63,804 \\
104,114\end{array}$ & $\begin{array}{l}62,908 \\
92,037\end{array}$ & $\begin{array}{l}61,178 \\
84,382\end{array}$ & $\begin{array}{l}53,389 \\
68,413\end{array}$ \\
\hline 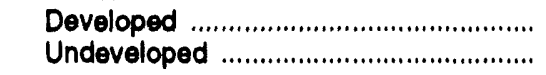 & $\begin{array}{l}10,242 \\
24,584\end{array}$ & $\begin{array}{l}10,552 \\
25,697\end{array}$ & $\begin{array}{l}11,134 \\
35,438\end{array}$ & $\begin{array}{l}10,532 \\
33,343\end{array}$ & $\begin{array}{l}10,829 \\
35,584\end{array}$ & $\begin{array}{l}10,673 \\
35,126\end{array}$ & $\begin{array}{l}10,602 \\
26,692\end{array}$ \\
\hline
\end{tabular}

Source: Energy Information Administration, Form EIA-28. 
Table B29. U.S. Net Petroleum Acreage for FRS Companies, Ranked by Total Energy Assets, 1992 and Percent Change from 1991

\begin{tabular}{|c|c|c|c|c|c|c|}
\hline \multirow[b]{2}{*}{$\begin{array}{c}\text { Petroloum } \\
\text { Aoroage }\end{array}$} & \multicolumn{2}{|c|}{ Undeveloped Acreage } & \multicolumn{2}{|c|}{ Developed Acreage } & \multicolumn{2}{|c|}{ Total Acreage } \\
\hline & $\begin{array}{c}\text { Thoueand } \\
\text { Acres }\end{array}$ & $\begin{array}{l}\text { Porcent } \\
\text { Chango } \\
\text { from } 1991\end{array}$ & $\begin{array}{c}\text { Thoueand } \\
\text { Acres }\end{array}$ & $\begin{array}{l}\text { Percont } \\
\text { Change } \\
\text { from } 1991\end{array}$ & $\begin{array}{c}\text { Thoueand } \\
\text { Acres }\end{array}$ & $\begin{array}{l}\text { Peroent } \\
\text { Change } \\
\text { from } 1901\end{array}$ \\
\hline 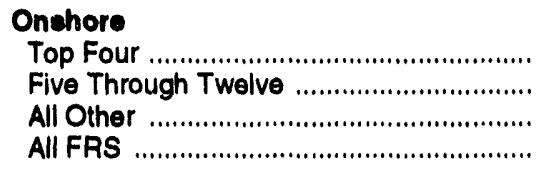 & $\begin{array}{l}10,933 \\
16,382 \\
17,118 \\
44,433\end{array}$ & $\begin{array}{r}-28.9 \\
-20.4 \\
-4.7 \\
-17.6\end{array}$ & $\begin{array}{r}10,229 \\
9,191 \\
10,170 \\
29,590\end{array}$ & $\begin{array}{r}-10.8 \\
-12.0 \\
11.5 \\
-4.7\end{array}$ & $\begin{array}{l}21,162 \\
25,573 \\
27,288 \\
74,023\end{array}$ & $\begin{array}{r}-21.2 \\
-17.6 \\
0.7 \\
-12.9\end{array}$ \\
\hline 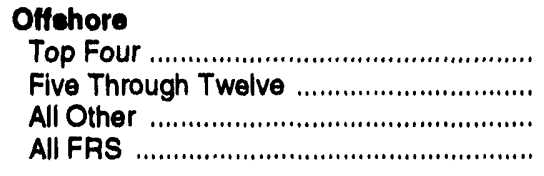 & $\begin{array}{r}6,588 \\
10,042 \\
4,207 \\
20,837\end{array}$ & $\begin{array}{r}-3.2 \\
-21.5 \\
23.7 \\
-9.4\end{array}$ & $\begin{array}{l}\mathbf{2}, 397 \\
1,524 \\
1,281 \\
5,202\end{array}$ & $\begin{array}{r}-14.4 \\
4.0 \\
31.8 \\
-0.7\end{array}$ & $\begin{array}{r}8,985 \\
11,566 \\
5,488 \\
26,039\end{array}$ & $\begin{array}{r}-6.4 \\
-18.9 \\
25.5 \\
-7.8\end{array}$ \\
\hline 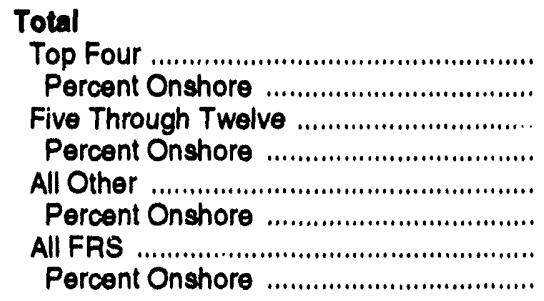 & $\begin{array}{r}17,521 \\
62.4 \\
26,424 \\
62.0 \\
21,325 \\
80.3 \\
65,270 \\
68.1\end{array}$ & $\begin{array}{r}-21.0 \\
. . \\
-20.8 \\
. . \\
-0.2 \\
. . \\
-15.1 \\
. .\end{array}$ & $\begin{array}{r}12,626 \\
81.0 \\
10,715 \\
85.8 \\
11,451 \\
88.8 \\
34,792 \\
85.0\end{array}$ & $\begin{array}{r}-11.5 \\
. . \\
-10.1 \\
. . \\
13.4 \\
. . \\
-4.1 \\
. .\end{array}$ & $\begin{array}{r}30,147 \\
70.2 \\
37,139 \\
68.9 \\
32,776 \\
83.3 \\
100,062 \\
74.0\end{array}$ & $\begin{array}{r}-17.3 \\
-18.0 \\
. \\
4.2 \\
. . \\
-11.6 \\
. .\end{array}$ \\
\hline
\end{tabular}

$\because=$ Not applicable.

Source: Energy Information Administration, Form ElA-28. 
Table B30. U.S. Net Ownership Interest Petroleum Reserves and Production for FRS Companies and U.S. Industry, 1992

\begin{tabular}{|c|c|c|c|c|}
\hline \multirow{2}{*}{ Reserves and Production } & \multicolumn{2}{|c|}{$\begin{array}{l}\text { Crude Oll and } \\
\text { Natural Gas Liquide } \\
\text { (billion barrels) }\end{array}$} & \multicolumn{2}{|c|}{$\begin{array}{c}\text { Natural Gas } \\
\text { (trillion cublc feet) }\end{array}$} \\
\hline & $\begin{array}{c}\text { FRS } \\
\text { Companies }\end{array}$ & $\begin{array}{c}\text { U.S. } \\
\text { Industry }\end{array}$ & $\begin{array}{c}\text { FRS } \\
\text { Companies }\end{array}$ & $\begin{array}{c}\text { U.S. } \\
\text { Industry }\end{array}$ \\
\hline \multicolumn{5}{|l|}{ Onshore } \\
\hline 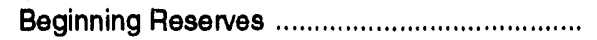 & 16.3 & 28.4 & 62.9 & 136.1 \\
\hline 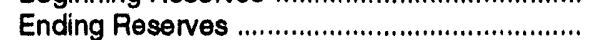 & 15.3 & 27.6 & 60.3 & 136.1 \\
\hline 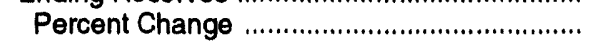 & -5.7 & -2.9 & -4.2 & 0.0 \\
\hline 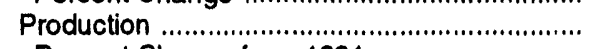 & 1.4 & 2.8 & 5.1 & 12.7 \\
\hline 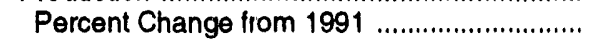 & -5.4 & -2.4 & 5.8 & 3.1 \\
\hline \multicolumn{5}{|l|}{ Offahore } \\
\hline 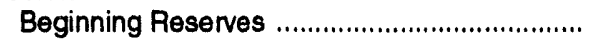 & 2.9 & 3.7 & 21.5 & 31.0 \\
\hline 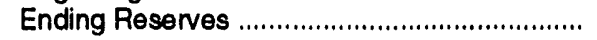 & 2.8 & 3.6 & 19.6 & 29.0 \\
\hline Percent Change & -3.8 & -3.3 & -8.5 & -6.6 \\
\hline Production & 0.3 & 0.5 & 2.8 & 4.8 \\
\hline 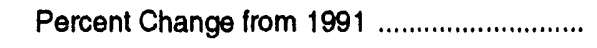 & 4.7 & 4.8 & 3.3 & -3.3 \\
\hline \multicolumn{5}{|l|}{ Total } \\
\hline 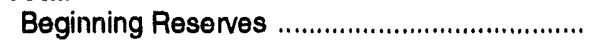 & 19.2 & 32.1 & 84.3 & 167.1 \\
\hline 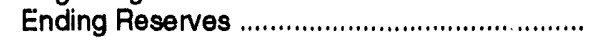 & 18.1 & 31.2 & 79.9 & 165.0 \\
\hline Percent Change & -5.4 & .3 .0 & -5.3 & -1.2 \\
\hline 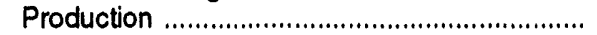 & 1.8 & 3.2 & 7.9 & 17.4 \\
\hline Percent Change from 1991 ........................... & -3.7 & .1 .4 & 4.9 & 1.3 \\
\hline
\end{tabular}

Note: 'Net Ownership Interest' is defined as Net working interest plus own royalty interest.

Sources: Industry data - Energy Information Administration Form ElA-23, seo U.S. Crude Oil, Natural Gas, and Natural Gas Liquids

Reserves Annual Report, 1991 and 1992 (September 1992 and October 1993). FRS companies data - Energy Informatior Administration, Form EIA-28. 
Table B31. Proved Petroleum Reserves for FRS Companies, United States and Foreign, 1992

\begin{tabular}{|c|c|c|c|c|c|c|c|}
\hline \multirow{2}{*}{ Reserves Statistios } & \multirow{2}{*}{$\begin{array}{c}\text { Worldwide } \\
\text { Total }\end{array}$} & \multicolumn{3}{|c|}{ United States } & \multicolumn{3}{|c|}{ Forelgn } \\
\hline & & Total & Onshore & Offshore & Total & Canada & Other \\
\hline & \multicolumn{7}{|c|}{ (million barrels) } \\
\hline \multirow[t]{2}{*}{ 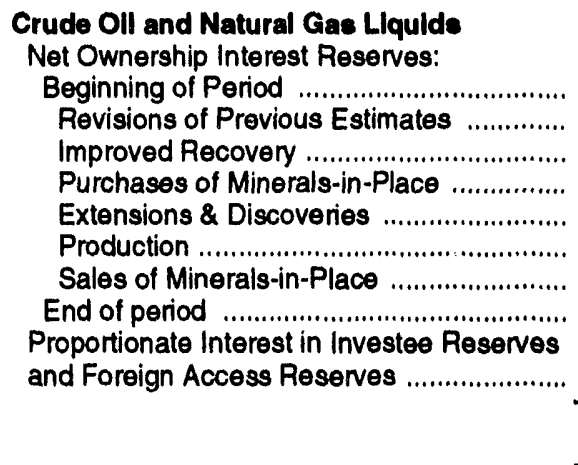 } & $\begin{array}{r}31,270 \\
731 \\
468 \\
231 \\
1,006 \\
-3,043 \\
-644 \\
30,019 \\
1,479\end{array}$ & $\begin{array}{r}19,158 \\
198 \\
279 \\
147 \\
498 \\
-1,750 \\
-403 \\
18,127 \\
-.\end{array}$ & $\begin{array}{r}16,259 \\
84 \\
277 \\
142 \\
365 \\
-1,442 \\
-346 \\
15,339\end{array}$ & $\begin{array}{r}2,900 \\
114 \\
2 \\
5 \\
133 \\
-308 \\
-57 \\
2,788\end{array}$ & $\begin{array}{r}12,112 \\
533 \\
189 \\
84 \\
508 \\
-1,292 \\
-241 \\
11,892 \\
1,479\end{array}$ & $\begin{array}{r}2,373 \\
24 \\
6 \\
63 \\
13 \\
-177 \\
-164 \\
2,139 \\
W\end{array}$ & $\begin{array}{r}9,739 \\
509 \\
183 \\
21 \\
494 \\
-1,115 \\
-77 \\
9,753 \\
W\end{array}$ \\
\hline & \multicolumn{7}{|c|}{ (billion cubic feet) } \\
\hline 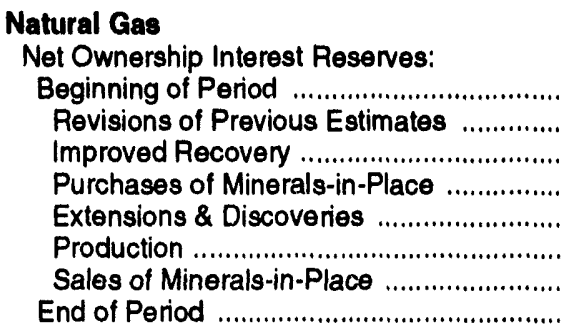 & $\begin{array}{r}138,579 \\
1,514 \\
851 \\
1,538 \\
7,258 \\
-11,742 \\
-4,231 \\
133,767\end{array}$ & $\begin{array}{r}84,334 \\
1,451 \\
224 \\
502 \\
3,767 \\
-7,878 \\
-2,505 \\
79,896\end{array}$ & $\begin{array}{r}62,879 \\
985 \\
203 \\
422 \\
2,641 \\
-5,094 \\
-1,774 \\
60,262\end{array}$ & $\begin{array}{r}21,455 \\
466 \\
21 \\
80 \\
1,126 \\
-2,784 \\
-730 \\
19,634\end{array}$ & $\begin{array}{r}54,245 \\
63 \\
627 \\
1,037 \\
3,491 \\
-3,865 \\
-1,726 \\
53,872\end{array}$ & $\begin{array}{r}12,702 \\
-233 \\
26 \\
679 \\
248 \\
-925 \\
-1,551 \\
10,946\end{array}$ & $\begin{array}{r}41,543 \\
296 \\
601 \\
358 \\
3,243 \\
-2,939 \\
-176 \\
42,925\end{array}$ \\
\hline
\end{tabular}


Table B32. U.S. Reserve Additions, Exploration and Development Expenditures, and Expenditures per Barrel of Reserve Additions for FRS Companies Ranked by Total Energy Assets and for U.S. Industry, 1990-1992

\begin{tabular}{|c|c|c|c|c|c|c|c|c|c|}
\hline \multirow{2}{*}{$\begin{array}{l}\text { Reserve Additions, } \\
\text { Expenditures, and Welle }\end{array}$} & \multicolumn{3}{|c|}{1990} & \multicolumn{3}{|c|}{1991} & \multicolumn{3}{|c|}{1992} \\
\hline & Onahore & OHshore & Total & Onshore & Offahore & Total & Onehore & Offehore & Total \\
\hline & \multicolumn{9}{|c|}{ (million barrels) } \\
\hline \multirow[t]{2}{*}{ 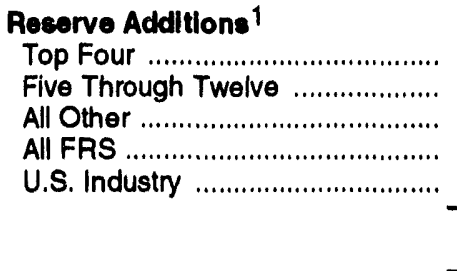 } & $\begin{array}{r}758.0 \\
1,028.4 \\
521.1 \\
2,307.5 \\
4,899.5\end{array}$ & $\begin{array}{r}338.1 \\
450.9 \\
-36.8 \\
752.2 \\
1,375.9\end{array}$ & $\begin{array}{r}1,096.0 \\
1,479.3 \\
484.2 \\
3,059.6 \\
6,275.4\end{array}$ & $\begin{array}{r}713.1 \\
616.7 \\
346.0 \\
1,675.9 \\
3,607.2\end{array}$ & $\begin{array}{r}338.3 \\
129.7 \\
88.5 \\
556.5 \\
620.2\end{array}$ & $\begin{array}{r}1,051.4 \\
746.5 \\
434.5 \\
2,232.3 \\
4,227.4\end{array}$ & $\begin{array}{r}568.4 \\
484.8 \\
355.1 \\
1,408.3 \\
4,195.4\end{array}$ & $\begin{array}{l}212.9 \\
186.7 \\
136.1 \\
535.6 \\
810.5\end{array}$ & $\begin{array}{r}781.3 \\
671.4 \\
491.2 \\
1,943.9 \\
5,005.9\end{array}$ \\
\hline & \multicolumn{9}{|c|}{ (million dollars) } \\
\hline \multirow[t]{2}{*}{ 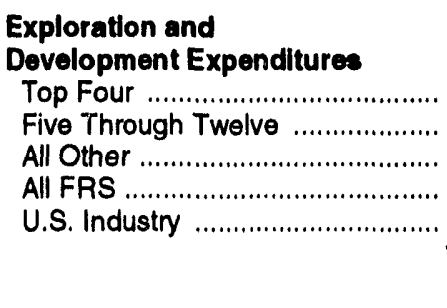 } & $\begin{array}{l}3,044.0 \\
3,901.0 \\
1,890.0 \\
8,835.0 \\
-\end{array}$ & $\begin{array}{r}1,642.0 \\
2,511.0 \\
748.0 \\
4,901.0 \\
-\end{array}$ & $\begin{array}{r}4,686.0 \\
6,412.0 \\
2,638.0 \\
13,736.0 \\
20,965.0\end{array}$ & $\begin{array}{c}3,032.0 \\
3,824.0 \\
1,631.0 \\
8,487.0 \\
-\end{array}$ & $\begin{array}{r}1,654.0 \\
2,246.0 \\
681.0 \\
4,581.0 \\
-\end{array}$ & $\begin{array}{r}4,686.0 \\
6,070.0 \\
2,312.0 \\
13,068.0 \\
-\end{array}$ & $\begin{array}{l}2,311.0 \\
2,814.0 \\
1,658.0 \\
6,783.0 \\
-\end{array}$ & $\begin{array}{r}1,014.0 \\
1,330.0 \\
646.0 \\
2,990.0 \\
-\end{array}$ & $\begin{array}{l}3,325.0 \\
4,144.0 \\
2,304.0 \\
9,773.0 \\
-\end{array}$ \\
\hline & \multicolumn{9}{|c|}{ (number of wells) } \\
\hline \multirow[t]{2}{*}{ 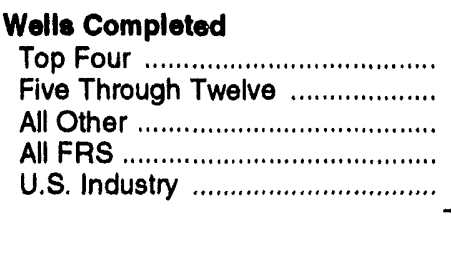 } & $\begin{array}{r}1,959.2 \\
2,857.3 \\
1,493.4 \\
6,309.9 \\
30,450.0\end{array}$ & $\begin{array}{r}167.0 \\
288.3 \\
85.9 \\
542.6 \\
1,045.0\end{array}$ & $\begin{array}{r}2,126.2 \\
3,145.6 \\
1,579.3 \\
6,852.5 \\
31,495.0\end{array}$ & $\begin{array}{r}1,651.2 \\
2,368.7 \\
1,133.6 \\
5,153.5 \\
28,085.0\end{array}$ & $\begin{array}{r}122.0 \\
208.6 \\
85.6 \\
416.2 \\
747.0\end{array}$ & $\begin{array}{r}1,773.2 \\
2,577.3 \\
1,219.2 \\
5,569.7 \\
28,832.0\end{array}$ & $\begin{array}{r}945.0 \\
1,717.5 \\
1,309.4 \\
3,971.9 \\
22,375.0\end{array}$ & $\begin{array}{r}66.0 \\
136.6 \\
68.0 \\
270.6 \\
360.0\end{array}$ & $\begin{array}{r}1,011.0 \\
1,854.1 \\
1,377.4 \\
4,242.5 \\
22,735.0\end{array}$ \\
\hline & \multicolumn{9}{|c|}{ (dollars per barrel) } \\
\hline \multirow[t]{2}{*}{ 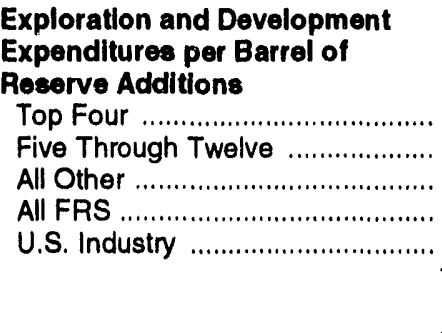 } & $\begin{array}{r}4.02 \\
3.79 \\
3.63 \\
3.83 \\
-\end{array}$ & $\begin{array}{r}4.86 \\
5.57 \\
-20.31 \\
6.52 \\
-\end{array}$ & $\begin{array}{l}4.28 \\
4.33 \\
5.45 \\
4.49 \\
3.34\end{array}$ & $\begin{array}{r}4.25 \\
6.20 \\
4.71 \\
5.06 \\
-\end{array}$ & $\begin{array}{r}4.89 \\
17.31 \\
7.70 \\
8.23 \\
-\end{array}$ & $\begin{array}{r}4.46 \\
8.13 \\
5.32 \\
5.85 \\
-\end{array}$ & $\begin{array}{r}4.07 \\
5.81 \\
4.67 \\
4.82 \\
-\end{array}$ & $\begin{array}{r}4.76 \\
7.13 \\
4.75 \\
5.58 \\
-\end{array}$ & $\begin{array}{r}4.26 \\
6.17 \\
4.69 \\
5.03 \\
-\end{array}$ \\
\hline & \multicolumn{9}{|c|}{ (thousand barrels) } \\
\hline $\begin{array}{l}\text { Reserve Additions per } \\
\text { Well Completed }\end{array}$ & & & & & & & & & \\
\hline 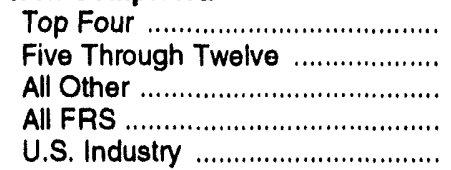 & $\begin{array}{l}386.5 \\
359.1 \\
348.1 \\
365.0 \\
160.5\end{array}$ & $\begin{array}{r}2,016.8 \\
1,560.6 \\
-429.5 \\
1,381.9 \\
1,312.3\end{array}$ & $\begin{array}{l}514.5 \\
469.2 \\
305.8 \\
445.5 \\
198.8\end{array}$ & $\begin{array}{l}431.3 \\
260.0 \\
304.4 \\
324.7 \\
128.1\end{array}$ & $\begin{array}{r}2,764.9 \\
619.8 \\
1,031.2 \\
1,333.2 \\
827.2\end{array}$ & $\begin{array}{l}591.9 \\
289.1 \\
355.4 \\
400.0 \\
146.2\end{array}$ & $\begin{array}{l}600.5 \\
281.7 \\
270.3 \\
353.8 \\
187.1\end{array}$ & $\begin{array}{l}3,217.7 \\
1,363.5 \\
1,996.0 \\
1,974.7 \\
2,245.3\end{array}$ & $\begin{array}{l}771.3 \\
361.4 \\
355.5 \\
457.2 \\
219.6\end{array}$ \\
\hline
\end{tabular}

1 Excludes net purchases of minerals in place, includes crude oil and natural gas liquids (measured in millions of barrels) and natural gas (measured in millions of barrels of crude equivalent). The conversion factor for natural gas is 0.178 barrels of crude / 1000 cubic feet. Reserve additions include the net of corrections and adjustments.

- = Not available.

Sources: Reserve additions - Energy Information Administration Form EIA-23, see U.S. Crude Oil, Natural Gas, and Natural Gas Liquids Reserves, 1990, 1991, and 1992 Annual Reports. Exploration and development expenditures - American Petroleum Institute, Survey on Oil ane Gas Expenditures, 1990 (Washington DC, November 1991). Wells completed - special compilation provided by the Office of Oil and Gas, Energy Information Administration. Totals are based on data which appeared in the Energy Information's Monthly Energy Review, September 1993 , p. 87. FRS companies data - Energy Information Administration, Form EIA-28. 
Table B33. Foreign Petroleum Exploration, Development, Reserves, and Production Statistics by Geographic Area for FRS Companies and Foreign Industry, 1992 and Percent Change from 1991

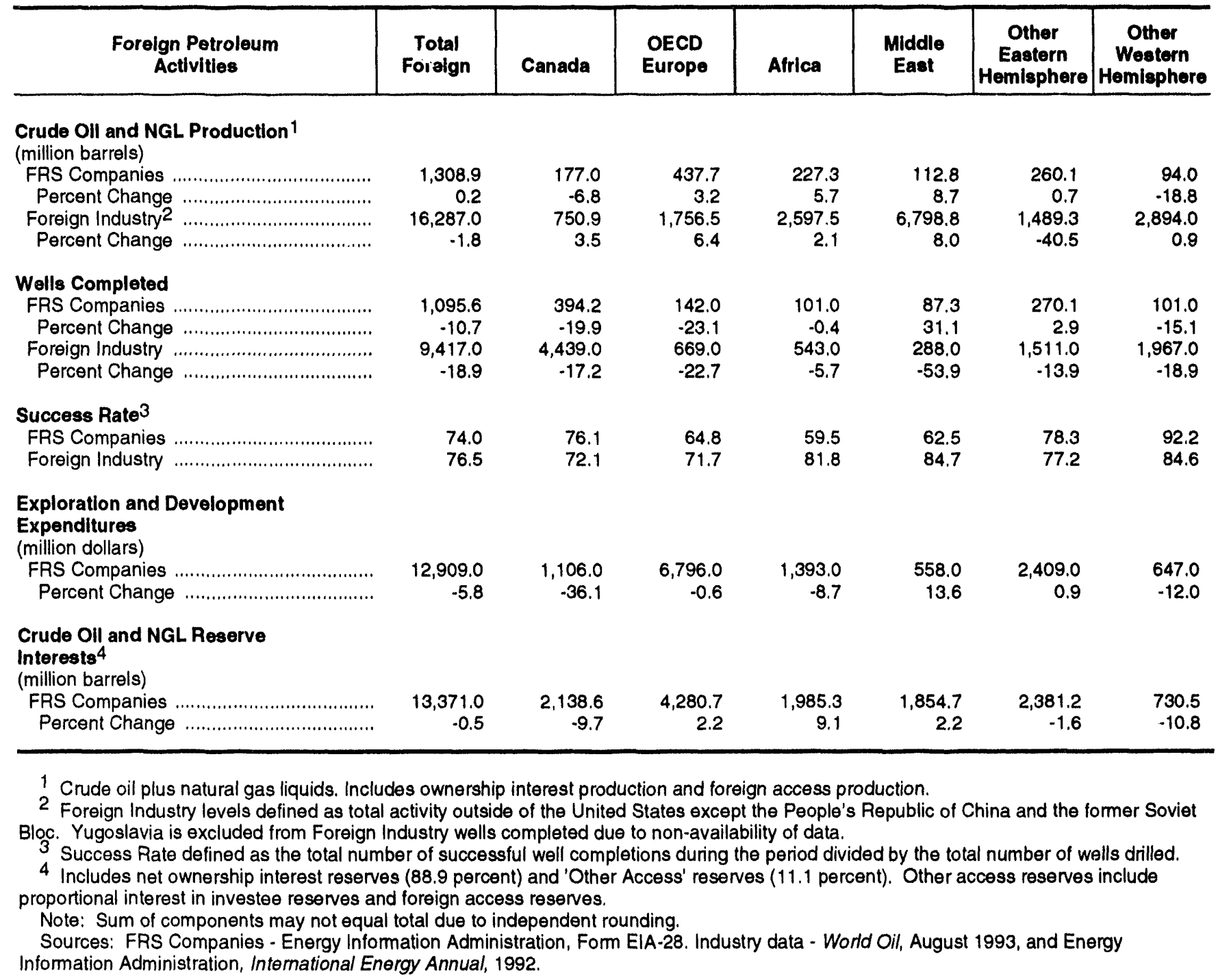


Table B34. Foreign Exploration and Development Expenditures by Region for FRS Companies, 1986-1992 (Million Dollars)

\begin{tabular}{|c|c|c|c|c|c|c|c|}
\hline Foreign Expenditures by Region & 1986 & 1987 & 1988 & 1989 & 1990 & 1991 & 1992 \\
\hline 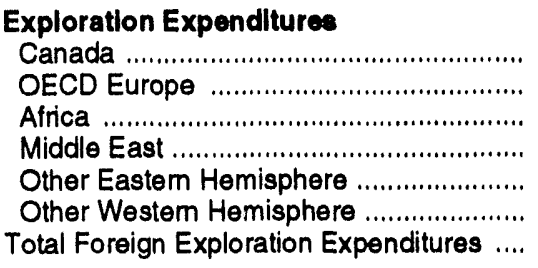 & $\begin{array}{r}508 \\
1,194 \\
647 \\
110 \\
456 \\
297 \\
3,213\end{array}$ & $\begin{array}{r}562 \\
1,095 \\
418 \\
124 \\
604 \\
266 \\
3,069\end{array}$ & $\begin{array}{r}1,124 \\
1,465 \\
494 \\
223 \\
604 \\
316 \\
4,226\end{array}$ & $\begin{array}{r}1,141 \\
1,132 \\
585 \\
197 \\
1,186 \\
304 \\
4,545\end{array}$ & $\begin{array}{r}753 \\
2,233 \\
618 \\
302 \\
1,017 \\
327 \\
5,250\end{array}$ & $\begin{array}{r}661 \\
2,192 \\
680 \\
258 \\
1,028 \\
435 \\
5,254\end{array}$ & $\begin{array}{r}336 \\
1,544 \\
738 \\
273 \\
869 \\
283 \\
4,043\end{array}$ \\
\hline 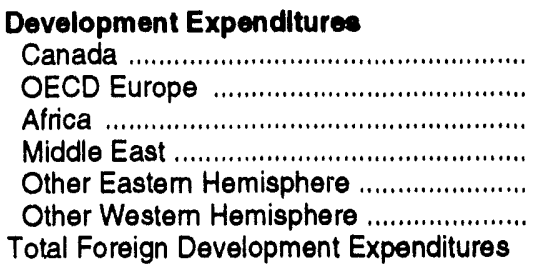 & $\begin{array}{r}618 \\
1,974 \\
417 \\
230 \\
730 \\
345 \\
4,313\end{array}$ & $\begin{array}{r}1,309 \\
1,889 \\
337 \\
261 \\
2,162 \\
194 \\
6,152\end{array}$ & $\begin{array}{r}4,277 \\
2,854 \\
346 \\
153 \\
765 \\
419 \\
8,814\end{array}$ & $\begin{array}{r}5,125 \\
2,407 \\
439 \\
209 \\
1,098 \\
305 \\
9,583\end{array}$ & $\begin{array}{r}1,065 \\
4,383 \\
807 \\
296 \\
1,416 \\
343 \\
8,310\end{array}$ & $\begin{array}{r}1,070 \\
4,643 \\
845 \\
233 \\
1,359 \\
300 \\
8,450\end{array}$ & $\begin{array}{r}770 \\
5,252 \\
655 \\
285 \\
1,540 \\
364 \\
8,866\end{array}$ \\
\hline 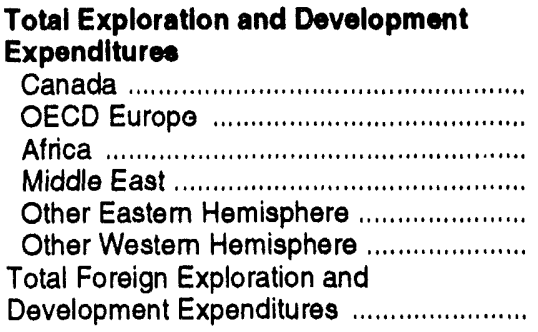 & $\begin{array}{r}1,125 \\
3,168 \\
1,064 \\
340 \\
1,186 \\
642\end{array}$ & $\begin{array}{r}1,871 \\
2,984 \\
755 \\
385 \\
2,766 \\
460\end{array}$ & $\begin{array}{r}5,401 \\
4,319 \\
840 \\
376 \\
1,369 \\
735\end{array}$ & $\begin{array}{r}6,266 \\
3,539 \\
1,024 \\
406 \\
2,284 \\
609\end{array}$ & $\begin{array}{r}1,818 \\
6,616 \\
1,425 \\
598 \\
2,433 \\
670\end{array}$ & $\begin{array}{r}1,731 \\
6,835 \\
1,525 \\
491 \\
2,387 \\
735\end{array}$ & $\begin{array}{r}1,106 \\
6,796 \\
1,393 \\
558 \\
2,409 \\
647\end{array}$ \\
\hline
\end{tabular}

Source: Energy Information Administration, Form ElA-28. 
Table B35. Distribution of Foreign Exploration and Development Expenditures for FRS Companies Ranked by Total Energy Assets, 1992 and Percent Change from 1991

\begin{tabular}{|c|c|c|c|c|c|c|}
\hline $\begin{array}{c}\text { Exploration and Development } \\
\text { Expendituree }\end{array}$ & $\begin{array}{l}\text { Total } \\
\text { Forolgn }\end{array}$ & Canada & $\begin{array}{l}\text { OECD } \\
\text { Europe }\end{array}$ & $\begin{array}{l}\text { Africa } \\
\text { and } \\
\text { Mideast }\end{array}$ & $\begin{array}{c}\text { Other } \\
\text { Eastern } \\
\text { Hemlephere }\end{array}$ & $\begin{array}{c}\text { Other } \\
\text { Western } \\
\text { Homlephere }\end{array}$ \\
\hline \multirow{3}{*}{ 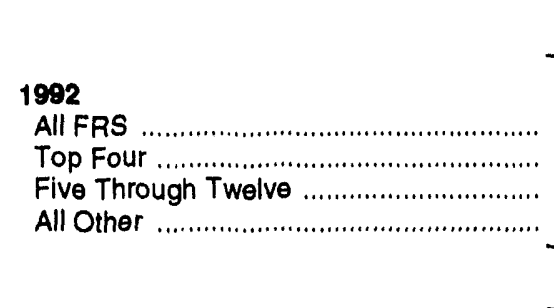 } & \multicolumn{6}{|c|}{ (million dollars) } \\
\hline & $\begin{array}{r}12,909.0 \\
6,603.0 \\
4,030.0 \\
2,276.0\end{array}$ & $\begin{array}{r}1,106.0 \\
634.0 \\
234.0 \\
238.0\end{array}$ & $\begin{array}{l}6,796.0 \\
3,590.0 \\
1,809.0 \\
1,397.0\end{array}$ & $\begin{array}{r}1,951.0 \\
796.0 \\
947.0 \\
208.0\end{array}$ & $\begin{array}{r}2,409.0 \\
1,376.0 \\
675.0 \\
358.0\end{array}$ & $\begin{array}{r}647.0 \\
207.0 \\
365.0 \\
75.0\end{array}$ \\
\hline & \multicolumn{6}{|c|}{ (percent) } \\
\hline 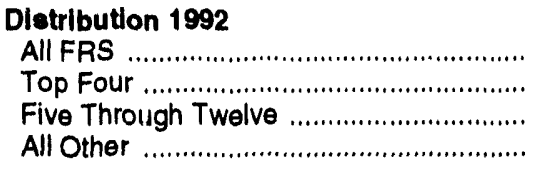 & $\begin{array}{l}100.0 \\
100.0 \\
100.0 \\
100.0\end{array}$ & $\begin{array}{r}8.6 \\
9.6 \\
5.8 \\
10.5\end{array}$ & $\begin{array}{l}52.6 \\
54.4 \\
44.9 \\
61.4\end{array}$ & $\begin{array}{r}15.1 \\
12.1 \\
23.5 \\
9.1\end{array}$ & $\begin{array}{l}18.7 \\
20.8 \\
16.7 \\
15.7\end{array}$ & $\begin{array}{l}5.0 \\
3.1 \\
9.1 \\
3.3\end{array}$ \\
\hline 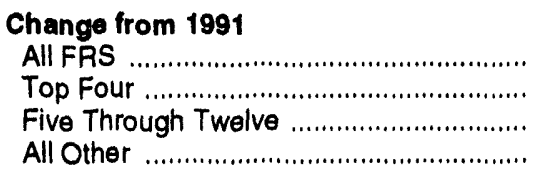 & $\begin{array}{r}-5.8 \\
2.0 \\
-21.1 \\
7.2\end{array}$ & $\begin{array}{l}-36.1 \\
-30.5 \\
-52.8 \\
-26.3\end{array}$ & $\begin{array}{r}-0.6 \\
14.3 \\
-26.7 \\
13.9\end{array}$ & $\begin{array}{r}-3.2 \\
0.8 \\
-13.9 \\
65.1\end{array}$ & $\begin{array}{r}0.9 \\
0.2 \\
4.0 \\
-1.9\end{array}$ & $\begin{array}{r}-12.0 \\
-20.1 \\
-6.9 \\
-10.7\end{array}$ \\
\hline
\end{tabular}

Source: Energy Information Administration, Form EIA-28. 
Table B36. Number of Net Wells Completed, Net In-Progress Wells, and Net Producing Wells in Foreign Areas for FRS Companies, 1986-1992

\begin{tabular}{|c|c|c|c|c|c|c|c|}
\hline Number of Wells & 1986 & 1987 & 1988 & 1989 & 1990 & 1991 & 1992 \\
\hline \multicolumn{8}{|l|}{ Canada } \\
\hline \multicolumn{8}{|l|}{$\begin{array}{l}\text { Net Wells Completed During Year } \\
\text { Exploratory Wells }\end{array}$} \\
\hline 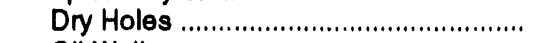 & 208.4 & 154.9 & 155.3 & 113.9 & 104.9 & 101.3 & 65.1 \\
\hline 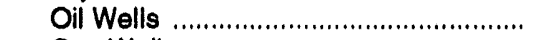 & 117.1 & 114.4 & 84.1 & 56.3 & 61.7 & 38.2 & 19.7 \\
\hline 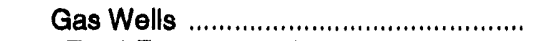 & 63.9 & 35.3 & 54.5 & 38.3 & 48.3 & 54.0 & 29.6 \\
\hline Total Exploratory Wells .......................... & 389.4 & 304.6 & 293.9 & 208.5 & 214.9 & 193.5 & 114.4 \\
\hline \multicolumn{8}{|l|}{ Development Wells } \\
\hline Dry Holes & 57.8 & 32.2 & 58.2 & 34.7 & 47.2 & 32.3 & 29.3 \\
\hline 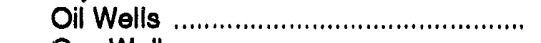 & 486.8 & 660.2 & 690.8 & 168.3 & 225.7 & 169.6 & 211.1 \\
\hline 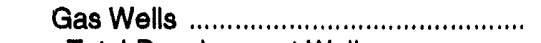 & 52.6 & 49.2 & 66.6 & 39.8 & 97.1 & 97.0 & 39.4 \\
\hline Total Development Wells ...................... & 597.2 & 741.6 & 815.6 & 242.8 & 370.0 & 298.9 & 279.8 \\
\hline $\begin{array}{l}\text { Net In-Progress Wells at Year End ......... } \\
\text { Net Producing Wells }\end{array}$ & 237.6 & 178.1 & 163.5 & 126.3 & 63.9 & 29.3 & 31.7 \\
\hline 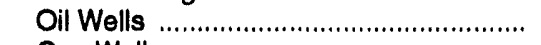 & $13,072.7$ & $13,187.5$ & $16,087.6$ & $15,880.1$ & $15,044.9$ & $13,996.6$ & $12,597.5$ \\
\hline 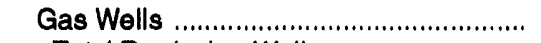 & $3,466.2$ & $3,783.3$ & $7,795.9$ & $7,162.6$ & $6,635.8$ & $6,094.0$ & $5,927.2$ \\
\hline Total Producing Wells ............................ & $16,538.9$ & $16,970.8$ & $23,883.5$ & $23,042.7$ & $21,680.7$ & $20,090.6$ & $18,524.7$ \\
\hline \multirow{2}{*}{\multicolumn{8}{|c|}{$\begin{array}{l}\text { OECD Europe } \\
\text { Net Wells Completed During Year } \\
\text { Exploratory Wells }\end{array}$}} \\
\hline & & & & & & & \\
\hline 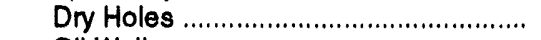 & 85.4 & 56.1 & 68.5 & 75.1 & 74.9 & 77.6 & 47.4 \\
\hline Oil Wells & 15.9 & 14.6 & 15.8 & 13.7 & 16.1 & 8.2 & 16.2 \\
\hline 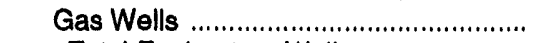 & 13.6 & 19.0 & 20.1 & 14.9 & 15.9 & 15.0 & 11.8 \\
\hline Total Exploratory Wells ........................... & 114.9 & 89.7 & 104.4 & 103.7 & 106.9 & 100.8 & 75.4 \\
\hline \multicolumn{8}{|l|}{ Development Wells } \\
\hline 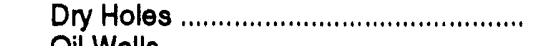 & 3.6 & 3.0 & 8.6 & 4.9 & 3.7 & 5.4 & 2.6 \\
\hline 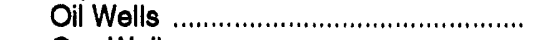 & 65.9 & 46.9 & 54.1 & 52.3 & 54.4 & 52.0 & 38.2 \\
\hline 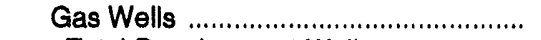 & 24.4 & 7.8 & 25.4 & 27.1 & 22.5 & 26.5 & 25.8 \\
\hline Total Development Wells ....................... & 93.9 & 57.7 & 88.1 & 84.3 & 80.6 & 83.9 & 66.6 \\
\hline $\begin{array}{l}\text { Net In-Progress Wells at Year End .......... } \\
\text { Net Producing Wells }\end{array}$ & 51.3 & 68.9 & 83.5 & 65.6 & 78.4 & 77.0 & 70.5 \\
\hline 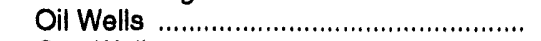 & $1,736.5$ & $1,750.7$ & $1,532.9$ & $1,436.8$ & $1,475.8$ & $1,462.0$ & $1,459.3$ \\
\hline 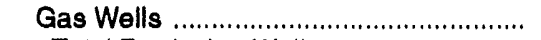 & 447.5 & 455.8 & 586.1 & 621.7 & 643.6 & 645.4 & 647.5 \\
\hline Total Producing Wells ............................. & $2,184.0$ & $2,206.5$ & $2,119.0$ & $2,058.5$ & $2,119.4$ & $2,107.4$ & $2,106.8$ \\
\hline \multirow{2}{*}{\multicolumn{8}{|c|}{$\begin{array}{l}\text { Afrlca and Middle East } \\
\text { Net Wells Completed During Year } \\
\text { Exploratory Wells }\end{array}$}} \\
\hline & & & & & & & \\
\hline 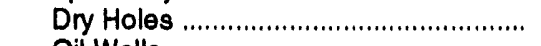 & 48.2 & 44.9 & 55.3 & 37.8 & 51.4 & 54.5 & 65.3 \\
\hline 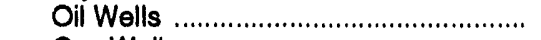 & $W$ & W & W & 14.5 & W & $W$ & W \\
\hline 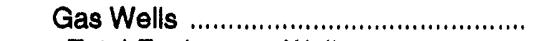 & $W$ & W & W & 1.7 & $W$ & $W$ & W \\
\hline Total Exploratory Wells ......................... & 62.7 & 57.1 & 74.3 & 54.0 & 67.5 & 73.9 & 84.8 \\
\hline \multicolumn{8}{|l|}{ Development Wells } \\
\hline 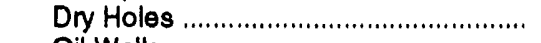 & $W$ & 5.0 & W & W & 6.6 & W & W \\
\hline Oil Wells ................................................ & 61.2 & 52.2 & 79.0 & 85.6 & 77.5 & 82.7 & 91.1 \\
\hline 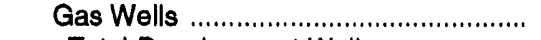 & W & 0.0 & W & W & 2.0 & $W$ & W \\
\hline Total Development Wells ....................... & 70.9 & 57.2 & 95.0 & 93.1 & 86.1 & 94.1 & 103.5 \\
\hline $\begin{array}{l}\text { Net In-Progress Wells at Year End .......... } \\
\text { Net Producing Wells }\end{array}$ & 58.5 & 52.8 & 47.0 & 48.0 & 29.0 & 44.0 & 34.4 \\
\hline 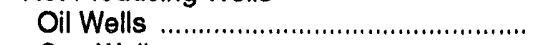 & 848.9 & 889.5 & $1,332.1$ & $1,349.2$ & $1,240.7$ & $1,294.2$ & $1,374.1$ \\
\hline 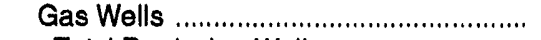 & 22.6 & 38.0 & 19.9 & 20.4 & 20.0 & 20.6 & 26.8 \\
\hline Total Producing Wells .............................. & 871.5 & 927.5 & $1,352.0$ & $1,369.6$ & $1,260.7$ & $1,314.8$ & $1,400.9$ \\
\hline
\end{tabular}

See footnotes at end of table. 
Table B36. Number of Not Wolls Complotod, Not In-Progress Wells, and Not Producing Wolls in Foreign Areas for FAS Companies, 1986-1992 (Continued)

\begin{tabular}{l|l|l|l|l|l|l|l|l|}
\hline Number of Wolle & 1986 & 1987 & 1988 & 1909 & 1900 & 1991 & 1902 \\
\hline
\end{tabular}

Other Eastern Hemlephere

Net Wells Completed During Year

Exploratory Wells

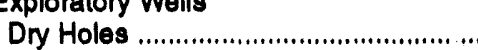

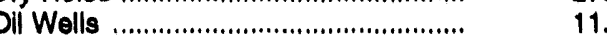

Total Exploratory Wells ....................

Development Wells

Dry Holes

Oil Wolls

Gas Wells ........................................

Total Development Wells ...................

Net in-Progress Wells at Year End

Net Producing Wells

Oil Wells

Gas Wells

Total Producing Wells

$\begin{array}{rrr}27.3 & 35.5 & 70.4 \\ 11.1 & 13.3 & 16.9 \\ 2.8 & 12.8 & 22.1 \\ 41.2 & 61.6 & 109.4 \\ & & \\ 3.9 & 1.0 & 2.9 \\ 145.1 & 76.6 & 105.8 \\ 29.1 & 22.0 & 29.8 \\ 178.1 & 99.6 & 138.6 \\ 40.4 & 51.3 & 58.9 \\ & & \\ 1,211.6 & 1,202.6 & 1,312.2 \\ 175.1 & 244.1 & 271.9 \\ 1,386.7 & 1,446.7 & 1,584.1\end{array}$

61.1
19.8
15.2
96.2

5.5
130.1
41.3
176.8
65.4
$1,468.3$
279.8
$1,748.1$

57.4
18.0
11.0
86.4

4.5

124.6

47.2

176.3

85.5

$1,632.9$

324.8

$1,857.7$

$\begin{array}{rr}60.5 & 47.6 \\ 21.1 & 22.9 \\ 11.4 & 10.0 \\ 93.0 & 80.6 \\ 14.5 & 11.0 \\ 106.4 & 108.7 \\ 48.6 & 71.9 \\ 169.5 & 189.6 \\ 89.4 & 71.5 \\ & \\ 1,532.1 & 1,650.2 \\ 321.1 & 373.2 \\ 1,853.2 & 2,023.4\end{array}$

Other Western Hemlephere

Net Wells Completed During Year

Exploratory Wells

Dry Holes

Oil Wells

Gas Wells

Total Exploratory Wells

Development Wells

Dry Holes

Oil Wells

Gas Wells

Total Development Wells

Net In-Progress Wells at Year End

Net Producing Wells

Oil Wells

Gas Wells

Total Producing Wells

29.3

W

$W$
41.0

W

125.6

158.2

13.0

$3,424.6$

127.4

$3,552.0$

$$
\begin{gathered}
16.1 \\
W \\
W \\
25.7 \\
W \\
W \\
117.7 \\
W \\
121.7 \\
17.0
\end{gathered}
$$

$3,413.8$

109.4

$3,523.2$
16.7

$W$
$W$

24.5

W

140.6

W

141.4

35.0

$3,277.0$

92.3

$3,369.3$

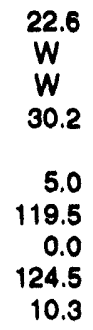

$3,276.8$

88.4

$3,365.2$
19.7

$$
\text { W }
$$

22.7

W

87.4

W

89.9

15.1

$3,102.0$

48.4

$3,150.4$
15.1

W

25.6

W

87.4

W

93.4

9.6

$3,145.5$

44.5

$3,190.0$

$2,938.3$

42.0

$2,980.3$

Total Forelgn

Net Wells Completed During Year

Exploratory Wells

Dry Holes

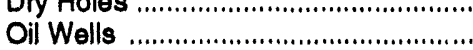

Gas Wells

Total Exploratory Wells

Development Wells

Dry Holes

Oil Wells

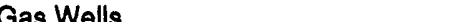

Total Development Wells ..................

Net In-Progress Wells at Year End

Net Producing Wells

Oil Wells

Gas Wells ......................................... $\quad 4,238.8$

398.6

307.5

159.9

71.3

366.2

310.5

308.3

309.0

232.3

83.6

649.2

538.7

100.6

107.9

74.2

112.7

77.4

95.5

81.0

606.5

492.6

498.4

486.8

367.1

90.7

42.2

84.1

57.2

123.0

953.6

82.0

$1,070.4$

124.2

$1,077.8$

$1,278.7$

555.8

108.6

64.5

61.3

52.2

569.6

168.8

498.1

534.1

142.2

$1,098.3$

721.6

802.9

728.5

215.5

$4,238.8$

$20,444.1$

$23,541.8$

$23,411.2$

271.8

249.3

$W=$ Data withheld to avoid disclosure.

Source: Energy Information Administration, Form ElA-28. 
Table B37. Forelgn Proved OII and Gas Reserves for FRS Companies, 1992

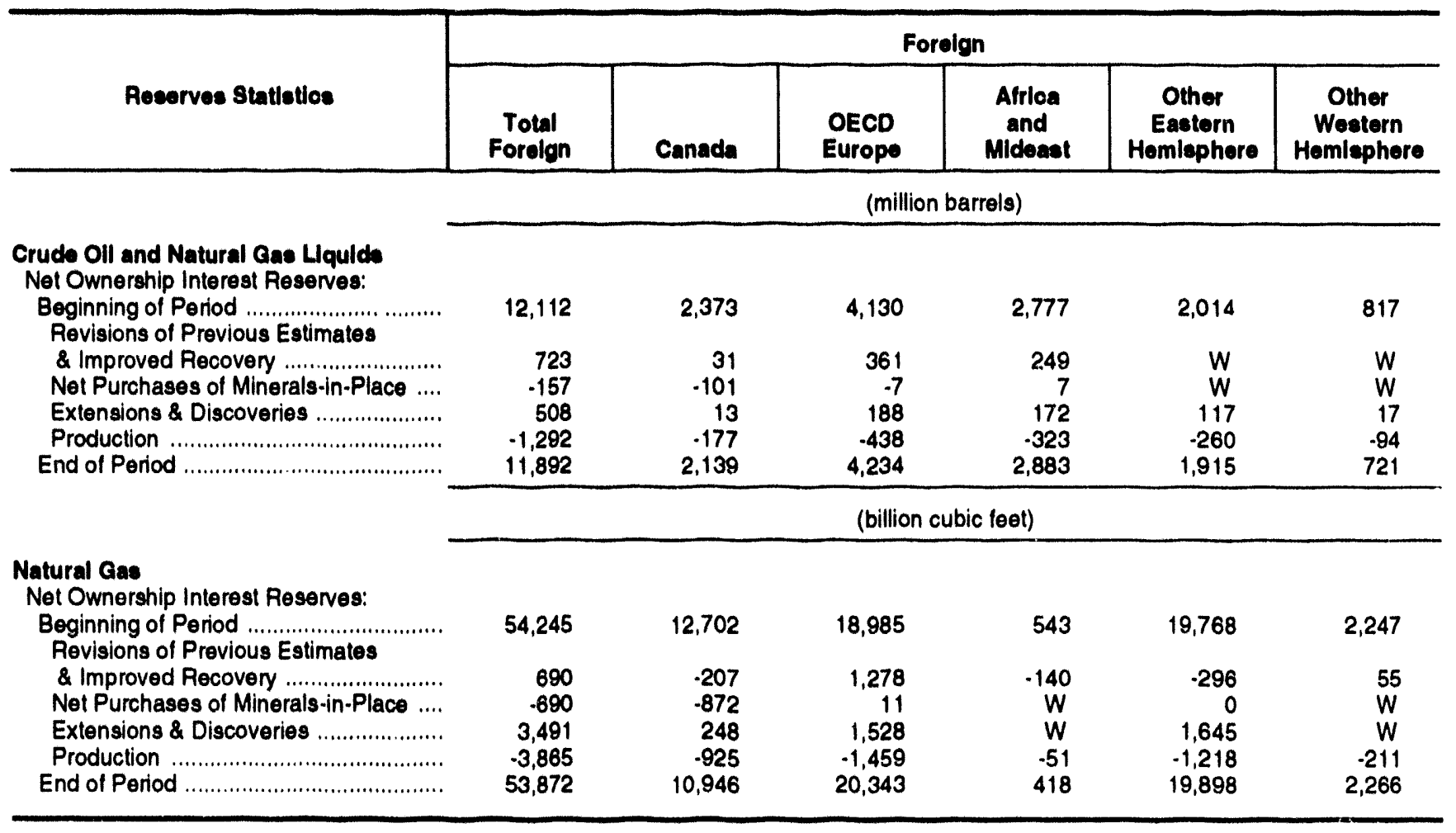

$W$ = Data withheld to avoid disclosure.

Source: Energy Information Administration, Form EIA-28. 
Table B38. Foreign Production (Lifting) Costs for FRS Companies, 1986-1992

(Million Dollars)

\begin{tabular}{|c|c|c|c|c|c|c|c|}
\hline Production Costs by Region & 1986 & 1987 & 1988 & 1989 & 1990 & 1991 & 1992 \\
\hline 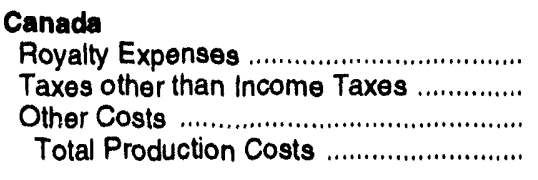 & $\begin{array}{r}W \\
W \\
996 \\
1,241\end{array}$ & $\begin{array}{r}W \\
W \\
976 \\
1,091\end{array}$ & $\begin{array}{r}W \\
W \\
1,323 \\
1,437\end{array}$ & $\begin{array}{r}19 \\
94 \\
1,528 \\
1,641\end{array}$ & $\begin{array}{r}W \\
W \\
1,736 \\
1,814\end{array}$ & $\begin{array}{r}W \\
W \\
1,797 \\
1,893\end{array}$ & $\begin{array}{r}W \\
W \\
1,894 \\
1,970\end{array}$ \\
\hline 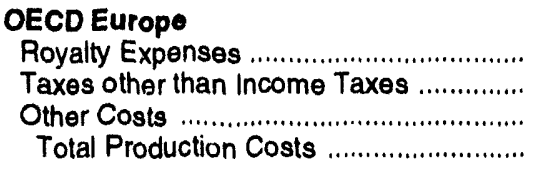 & $\begin{array}{r}402 \\
144 \\
2,189 \\
2,734\end{array}$ & $\begin{array}{r}420 \\
166 \\
2,991 \\
3,577\end{array}$ & $\begin{array}{r}300 \\
153 \\
3,147 \\
3,600\end{array}$ & $\begin{array}{r}224 \\
100 \\
3,073 \\
3,397\end{array}$ & $\begin{array}{r}544 \\
270 \\
3,692 \\
4,506\end{array}$ & $\begin{array}{r}495 \\
229 \\
4,353 \\
5,077\end{array}$ & $\begin{array}{r}465 \\
257 \\
4,199 \\
4,921\end{array}$ \\
\hline 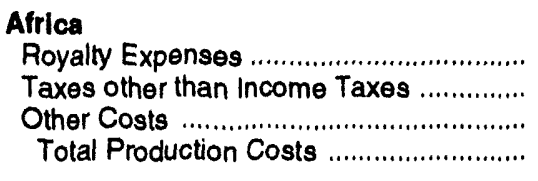 & $\begin{array}{r}553 \\
21 \\
671 \\
1,245\end{array}$ & $\begin{array}{r}438 \\
15 \\
495 \\
948\end{array}$ & $\begin{array}{r}170 \\
31 \\
575 \\
776\end{array}$ & $\begin{array}{r}210 \\
14 \\
480 \\
704\end{array}$ & $\begin{array}{l}W \\
W \\
625 \\
951\end{array}$ & $\begin{array}{l}W \\
W \\
680 \\
989\end{array}$ & $\begin{array}{r}W \\
W \\
776 \\
1,079\end{array}$ \\
\hline 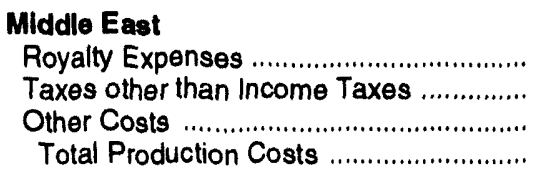 & $\begin{array}{l}128 \\
118 \\
309 \\
555\end{array}$ & $\begin{array}{l}146 \\
154 \\
286 \\
586\end{array}$ & $\begin{array}{r}103 \\
72 \\
273 \\
448\end{array}$ & $\begin{array}{c}W \\
W \\
295 \\
454\end{array}$ & $\begin{array}{c}W \\
W \\
305 \\
468\end{array}$ & $\begin{array}{c}W \\
W \\
217 \\
316\end{array}$ & $\begin{array}{r}62 \\
292 \\
324 \\
678\end{array}$ \\
\hline 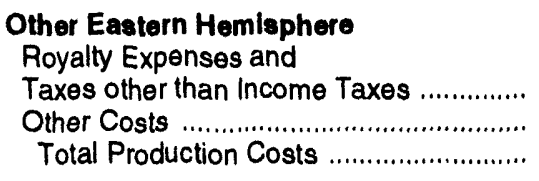 & $\begin{array}{r}797 \\
801 \\
1,598\end{array}$ & $\begin{array}{r}914 \\
755 \\
1,669\end{array}$ & $\begin{array}{r}608 \\
920 \\
1,528\end{array}$ & $\begin{array}{r}566 \\
972 \\
1,538\end{array}$ & $\begin{array}{r}687 \\
1,318 \\
2,005\end{array}$ & $\begin{array}{r}730 \\
1,420 \\
2,150\end{array}$ & $\begin{array}{r}685 \\
1,400 \\
2,085\end{array}$ \\
\hline $\begin{array}{l}\text { Other Western Hemisphere } \\
\text { Royalty Expenses and } \\
\text { Taxes other than Income Taxes .............. } \\
\text { Other Costs ...................................... } \\
\text { Total Production Costs ......................... }\end{array}$ & $\begin{array}{l}287 \\
393 \\
681\end{array}$ & $\begin{array}{l}302 \\
412 \\
714\end{array}$ & $\begin{array}{l}196 \\
387 \\
583\end{array}$ & $\begin{array}{l}210 \\
482 \\
692\end{array}$ & $\begin{array}{l}312 \\
530 \\
842\end{array}$ & $\begin{array}{l}230 \\
481 \\
711\end{array}$ & $\begin{array}{l}137 \\
450 \\
587\end{array}$ \\
\hline 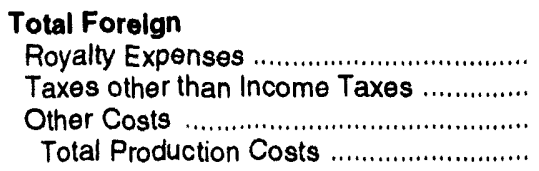 & $\begin{array}{l}1,259 \\
1,435 \\
5,359 \\
8,053\end{array}$ & $\begin{array}{l}1,217 \\
1,453 \\
5,915 \\
8,585\end{array}$ & $\begin{array}{r}697 \\
1,050 \\
6,625 \\
8,372\end{array}$ & $\begin{array}{r}618 \\
978 \\
6,830 \\
8,426\end{array}$ & $\begin{array}{r}1,107 \\
1,273 \\
8,206 \\
10,586\end{array}$ & $\begin{array}{r}968 \\
1,220 \\
8,948 \\
11,136\end{array}$ & $\begin{array}{r}991 \\
1,286 \\
9,043 \\
11,320\end{array}$ \\
\hline
\end{tabular}

$W$ = Data withheld to avoid disclosure.

Source: Energy Information Administration, Form ElA-28. 
Table B39. U.S. Refining/Marketing Dispositions of Refined Products by Channel of Distribution for FRS Companies, 1986-1992

\begin{tabular}{|c|c|c|c|c|c|c|c|}
\hline U.S. Dispositions & 1986 & 1987 & 1988 & 1989 & 1980 & 1991 & 1992 \\
\hline & \multicolumn{7}{|c|}{ Values (million dollars) } \\
\hline \multicolumn{8}{|l|}{ Motor Gasoline } \\
\hline $\begin{array}{l}\text { Intersegment Sales ....................................... } \\
\text { U.S. Third-Party Sales }\end{array}$ & 163 & 189 & 194 & 244 & 247 & 568 & 231 \\
\hline $\begin{array}{l}\text { Wholesale-Resellers ................................. } \\
\text { Company Operated Automotive }\end{array}$ & 24,796 & 26,394 & 25,313 & 26,451 & 33,255 & 28,854 & 26,641 \\
\hline $\begin{array}{l}\text { Outlets } \\
\text { Company Lessee and Open }\end{array}$ & 8,419 & 9,101 & 9,733 & 11,308 & 14,238 & 13,059 & 12,049 \\
\hline $\begin{array}{l}\text { Automotive Outlets ................................ } \\
\text { Other (Industrial, Commercial }\end{array}$ & 17,271 & 19,445 & 20,284 & 23,050 & 25,373 & 22,459 & 23,061 \\
\hline 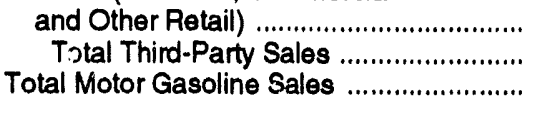 & $\begin{array}{r}3,486 \\
53,972 \\
54,136\end{array}$ & $\begin{array}{r}5,107 \\
60,047 \\
60,236\end{array}$ & $\begin{array}{r}5,045 \\
60,375 \\
60,569\end{array}$ & $\begin{array}{r}4,566 \\
65,375 \\
65,619\end{array}$ & $\begin{array}{r}4,576 \\
77,442 \\
77,689\end{array}$ & $\begin{array}{r}4,043 \\
68,415 \\
68,983\end{array}$ & $\begin{array}{r}5,713 \\
67,464 \\
67,695\end{array}$ \\
\hline \multicolumn{8}{|l|}{ Dlstillate Fuels } \\
\hline 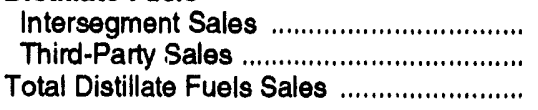 & $\begin{array}{r}231 \\
27,111 \\
27,342\end{array}$ & $\begin{array}{r}214 \\
29,523 \\
29,737\end{array}$ & $\begin{array}{r}311 \\
28,218 \\
28,529\end{array}$ & $\begin{array}{r}398 \\
32,277 \\
32,675\end{array}$ & $\begin{array}{r}473 \\
40,222 \\
40,695\end{array}$ & $\begin{array}{r}483 \\
35,052 \\
35,535\end{array}$ & $\begin{array}{r}550 \\
33,370 \\
33,920\end{array}$ \\
\hline 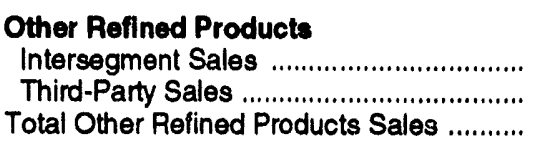 & $\begin{array}{r}4,468 \\
17,060 \\
21,528\end{array}$ & $\begin{array}{r}4,283 \\
20,481 \\
24,764\end{array}$ & $\begin{array}{r}4,404 \\
17,388 \\
21,792\end{array}$ & $\begin{array}{r}4,511 \\
19,124 \\
23,635\end{array}$ & $\begin{array}{r}5,093 \\
20,945 \\
26,038\end{array}$ & $\begin{array}{r}4,435 \\
19,032 \\
23,467\end{array}$ & $\begin{array}{r}4,671 \\
17,854 \\
22,525\end{array}$ \\
\hline 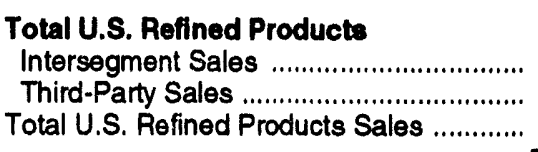 & $\begin{array}{r}4,863 \\
98,143 \\
103,006\end{array}$ & $\begin{array}{r}4,686 \\
110,051 \\
114,737\end{array}$ & $\begin{array}{r}4,909 \\
105,981 \\
110,890\end{array}$ & $\begin{array}{r}5,153 \\
116,776 \\
121,929\end{array}$ & $\begin{array}{r}5,813 \\
138,609 \\
144,422\end{array}$ & $\begin{array}{r}5,486 \\
122,499 \\
127,985\end{array}$ & $\begin{array}{r}5,452 \\
118,688 \\
124,140\end{array}$ \\
\hline & \multicolumn{7}{|c|}{ Volumes (million barrels) } \\
\hline Motor Gasoline & & & & & & & \\
\hline 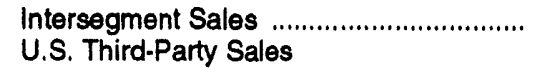 & 8 & 8 & 9 & 12 & 8 & 18 & 9 \\
\hline $\begin{array}{l}\text { Wholesale-Resellers ................................. } \\
\text { Company Operated Automotive }\end{array}$ & 1,173 & 1,109 & 1,107 & 1,007 & 1,072 & 996 & 972 \\
\hline $\begin{array}{l}\text { Outlets . } \\
\text { Company Lessee and Open }\end{array}$ & 312 & 318 & 340 & 356 & 384 & 367 & 350 \\
\hline 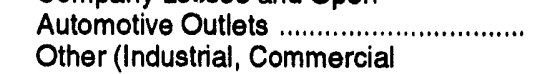 & 687 & 718 & 742 & 768 & 719 & 734 & 740 \\
\hline 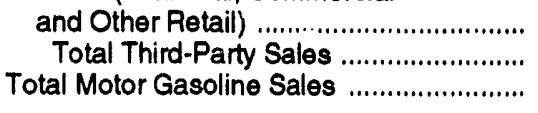 & $\begin{array}{r}163 \\
2,334 \\
2,342\end{array}$ & $\begin{array}{r}245 \\
2,390 \\
2,399\end{array}$ & $\begin{array}{r}262 \\
2,451 \\
2,460\end{array}$ & $\begin{array}{r}184 \\
2,314 \\
2,325\end{array}$ & $\begin{array}{r}163 \\
2,338 \\
2,346\end{array}$ & $\begin{array}{r}151 \\
2,248 \\
2,267\end{array}$ & $\begin{array}{r}216 \\
2,277 \\
2,286\end{array}$ \\
\hline Distillate Fuels & & & & & & & \\
\hline 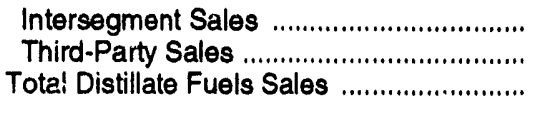 & $\begin{array}{r}13 \\
1,309 \\
1,321\end{array}$ & $\begin{array}{r}10 \\
1,345 \\
1,355\end{array}$ & $\begin{array}{r}16 \\
1,395 \\
1,411\end{array}$ & $\begin{array}{r}16 \\
1,345 \\
1,361\end{array}$ & $\begin{array}{r}16 \\
1,356 \\
1,372\end{array}$ & $\begin{array}{r}19 \\
1,328 \\
1,347\end{array}$ & $\begin{array}{r}24 \\
1,340 \\
1,364\end{array}$ \\
\hline $\begin{array}{l}\text { Other Refined Products } \\
\text { Intersegment Sales .................................. } \\
\text { Third-Party Sales ................................. } \\
\text { Total Other Refined Products Sales ........... }\end{array}$ & $\begin{array}{r}270 \\
367 \\
1,237\end{array}$ & $\begin{array}{r}251 \\
1,044 \\
1,295\end{array}$ & $\begin{array}{r}272 \\
1,010 \\
1,281\end{array}$ & $\begin{array}{r}232 \\
1,004 \\
1,236\end{array}$ & $\begin{array}{r}230 \\
879 \\
1,108\end{array}$ & $\begin{array}{r}212 \\
925 \\
1,137\end{array}$ & $\begin{array}{r}232 \\
896 \\
1,128\end{array}$ \\
\hline 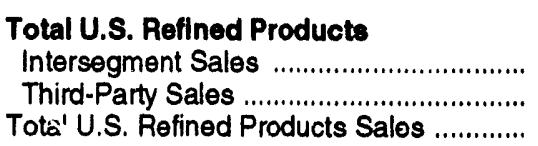 & $\begin{array}{r}291 \\
4,610 \\
4,901\end{array}$ & $\begin{array}{r}270 \\
4,779 \\
5,049\end{array}$ & $\begin{array}{r}296 \\
4,855 \\
5,152\end{array}$ & $\begin{array}{r}260 \\
4,663 \\
4,923\end{array}$ & $\begin{array}{r}253 \\
4,573 \\
4,826\end{array}$ & $\begin{array}{r}249 \\
4,502 \\
4,751\end{array}$ & $\begin{array}{r}264 \\
4,513 \\
4,778\end{array}$ \\
\hline
\end{tabular}

See footnotes at end of table. 
Table B39. U.S. Refining/Marketing Dispositions of Refined Products by Channel of Distribution for FRS Companies, 1986-1992 (Continued)

\begin{tabular}{|c|c|c|c|c|c|c|c|}
\hline U.S. Dispositions & 1986 & 1987 & 1988 & 1989 & 1990 & 1991 & 1992 \\
\hline & \multicolumn{7}{|c|}{ Number of Automotive Outlets } \\
\hline \multirow{2}{*}{ 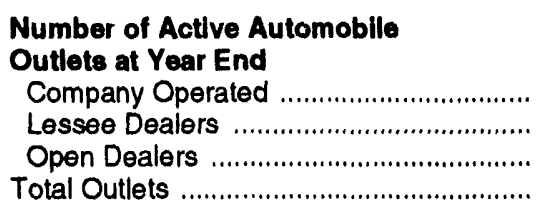 } & & & & & & & \\
\hline & $\begin{array}{r}9,327 \\
24,200 \\
30,033 \\
63,560\end{array}$ & $\begin{array}{r}9,837 \\
23,103 \\
28,279 \\
61,219\end{array}$ & $\begin{array}{l}10,712 \\
22,569 \\
32,919 \\
66,200\end{array}$ & $\begin{array}{l}10,995 \\
21,114 \\
21,475 \\
53,584\end{array}$ & $\begin{array}{l}11,177 \\
20,376 \\
19,532 \\
51,085\end{array}$ & $\begin{array}{l}10,745 \\
19,891 \\
17,969 \\
48,605\end{array}$ & $\begin{array}{r}9,935 \\
19,334 \\
17,297 \\
46,566\end{array}$ \\
\hline
\end{tabular}

Source: Energy Information Administration, Form ElA-28. 
Table B40. Sales of U.S. Refined Products, by Volume and Price, for FRS Companies Ranked by Total Energy Assets, 1991 and 1992

(Million Barrels and Dollars per Barrel)

\begin{tabular}{|c|c|c|c|c|c|c|c|c|}
\hline \multirow{2}{*}{ Product Distrlbution Channel } & \multicolumn{2}{|c|}{ All FRS } & \multicolumn{2}{|c|}{ Top Four } & \multicolumn{2}{|c|}{$\begin{array}{l}\text { Five Through } \\
\text { Twelve }\end{array}$} & \multicolumn{2}{|c|}{ All Other } \\
\hline & Volume & Price & Volume & Price & Volume & Price & Volume & Price \\
\hline \multicolumn{9}{|l|}{$\begin{array}{l}\text { Gasoline } \\
\text { Intra-Company Sales }\end{array}$} \\
\hline 1992 & $\begin{array}{r}9.2 \\
18.4\end{array}$ & $\begin{array}{l}25.10 \\
30.81\end{array}$ & $\begin{array}{l}7.7 \\
8.1\end{array}$ & $\begin{array}{l}25.28 \\
27.31\end{array}$ & $\begin{array}{l}0.1 \\
9.0\end{array}$ & $\begin{array}{l}25.32 \\
34.37\end{array}$ & $\begin{array}{l}1.4 \\
1.3\end{array}$ & $\begin{array}{l}24.11 \\
27.82\end{array}$ \\
\hline $\begin{array}{l}\text { Percent Change .......................................... } \\
\text { Wholesale/Resellers }\end{array}$ & -50.1 & -18.5 & -5.1 & -7.4 & -99.1 & -26.3 & 12.1 & -13.3 \\
\hline 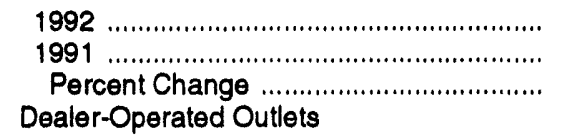 & $\begin{array}{r}971.5 \\
996.2 \\
-2.5\end{array}$ & $\begin{array}{r}27.42 \\
28.96 \\
-5.3\end{array}$ & $\begin{array}{r}366.2 \\
343.9 \\
6.5\end{array}$ & $\begin{array}{r}26.69 \\
28.23 \\
-5.4\end{array}$ & $\begin{array}{r}368.2 \\
450.0 \\
-18.2\end{array}$ & $\begin{array}{r}28.83 \\
29.67 \\
-2.8\end{array}$ & $\begin{array}{r}237.2 \\
202.3 \\
17.2\end{array}$ & $\begin{array}{r}26.36 \\
28.65 \\
-8.0\end{array}$ \\
\hline $1992 \ldots$ & 740.0 & 31.16 & 275.5 & 32.34 & 316.0 & 30.68 & 148.6 & 29.99 \\
\hline $1991 \ldots \ldots \ldots \ldots \ldots \ldots$ & 734.3 & 30.58 & 275.9 & 31.45 & 307.4 & 30.12 & 151.1 & 29.94 \\
\hline $\begin{array}{l}\text { Percent Change } \\
\text { Company-Operated Outlets }\end{array}$ & 0.8 & 1.9 & -0.1 & 2.8 & 2.8 & 1.9 & -1.7 & 0.2 \\
\hline 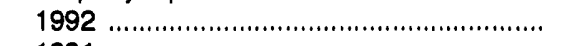 & 349.7 & 34.45 & 97.8 & 34.87 & 167.0 & 34.59 & 84.9 & 33.71 \\
\hline 1991 & 367.0 & 35.58 & 104.5 & 34,52 & 163.4 & 35.20 & 99.1 & 37.32 \\
\hline 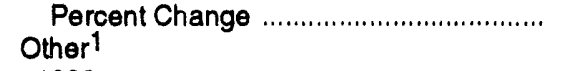 & -4.7 & -3.2 & -6.4 & 1.0 & 2.2 & -1.7 & -14.3 & -9.7 \\
\hline $1992, \ldots \ldots \ldots \ldots \ldots \ldots$ & 215.9 & 26.47 & 21.3 & 29.14 & 92.8 & 26.63 & 101.8 & 25.76 \\
\hline 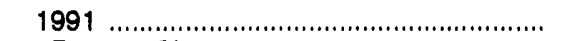 & 150.8 & 26.81 & 22.3 & 28.81 & 56.8 & 28.29 & 71.7 & 25.01 \\
\hline 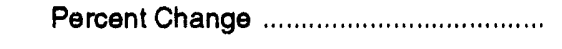 & 43.1 & -1.3 & -4.7 & 1.2 & 63.4 & -5.8 & 41.9 & 3.0 \\
\hline \multicolumn{9}{|l|}{ Total Gasoline } \\
\hline 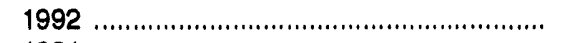 & $2,286.3$ & 29.61 & 768.4 & 29.81 & 944.0 & 30.25 & 573.9 & 28.28 \\
\hline 1991 & $2,266.8$ & 30.43 & 754.7 & 30.29 & 986.6 & 30.69 & 525.5 & 30.16 \\
\hline 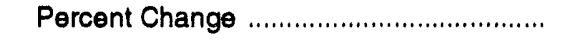 & 0.9 & -2.7 & 1.8 & -1.6 & -4.3 & -1.4 & 9.2 & -6.2 \\
\hline \multicolumn{9}{|l|}{ Distlllate } \\
\hline 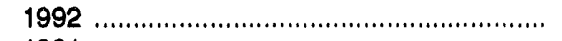 & $1,363.7$ & 24.87 & 499.1 & 24.66 & 487.6 & 25.16 & 377.0 & 24.79 \\
\hline 1991 & $1,346.7$ & 26.39 & 474.1 & 26.32 & 527.4 & 26.32 & 345.1 & 26.59 \\
\hline 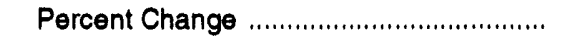 & 1.3 & -5.7 & 5.3 & -6.3 & -7.5 & -4.4 & 9.2 & -6.8 \\
\hline \multicolumn{9}{|l|}{ All Other Products } \\
\hline 1992 & $1,127.6$ & 19.98 & 379.6 & 22.14 & 371.0 & 19.04 & 377.0 & 18.72 \\
\hline 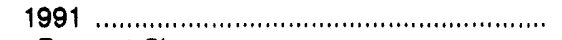 & $1,137.1$ & 20.64 & 369.2 & 22.59 & 456.0 & 19.38 & 311.8 & 20.17 \\
\hline 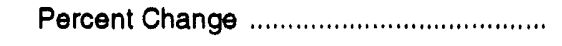 & -0.8 & -3.2 & 2.8 & -2.0 & -18.6 & $\cdot 1.8$ & 20.9 & -7.2 \\
\hline \multicolumn{9}{|l|}{ Total Refined Producte } \\
\hline $1992 \ldots \ldots \ldots$ & $4,777.6$ & 25.98 & $1,647.1$ & 26.48 & $1,802.6$ & 26.57 & $1,327.9$ & 24.57 \\
\hline $1991 \ldots \ldots \ldots \ldots \ldots$ & $4,750.6$ & 26.94 & $1,598.1$ & 27.33 & $1,970.0$ & 26.90 & $1,182.5$ & 26.48 \\
\hline 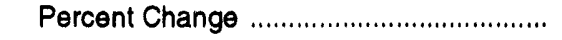 & 0.6 & -3.6 & 3.1 & -3.1 & -8.5 & -1.2 & 12.3 & -7.2 \\
\hline
\end{tabular}

1 Includes direct sales to industrial and commercial customers and sales to unconsolidated affiliates.

Note: Sum of components may not equal total due to independent rounding.

Source: Energy Information Administration, Form ElA-28. 
Table B41. U.S. Petroleum Refining/Marketing, General Operating Expenses for FRS Companies, 1986-1992 (Billion Dollars)

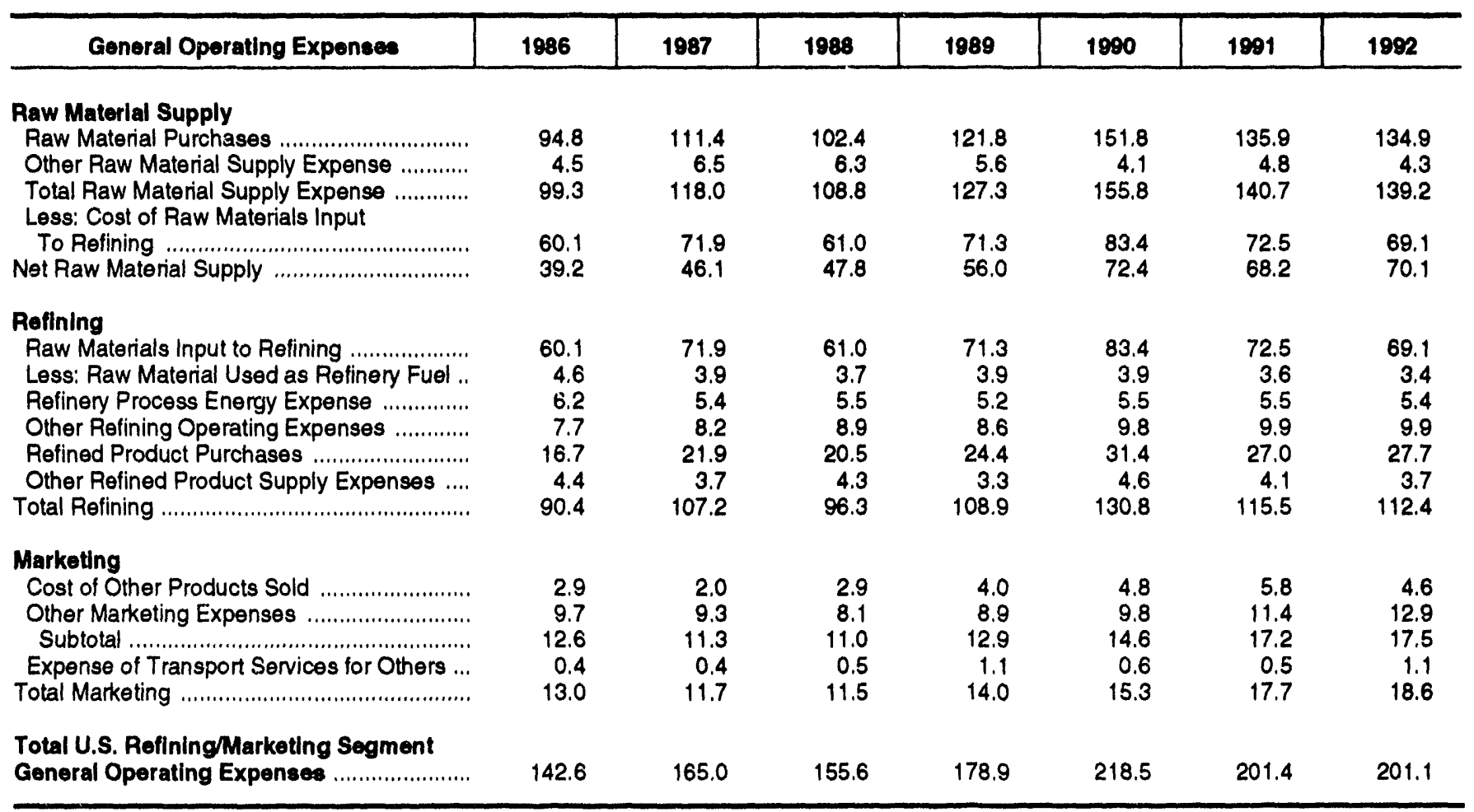

Source: Energy Information Administration, Form ElA-28. 
Table B42. U.S. Petroleum Segments Purchases and Sales of Raw Materials and Refined Products for FRS Companies, 1986-1992

\begin{tabular}{|c|c|c|c|c|c|c|c|}
\hline Purchases and Sales & 1986 & 1987 & 1988 & 1989 & 1990 & 1991 & 1992 \\
\hline & \multicolumn{7}{|c|}{ Values (million dollars) } \\
\hline \multicolumn{8}{|l|}{$\begin{array}{l}\text { Purchases } \\
\text { U.S. Refining/Marketing Segment } \\
\text { Raw Materials }\end{array}$} \\
\hline 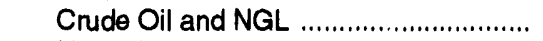 & 89,168 & 105,881 & 97,203 & 116,552 & 144,973 & 129,380 & 124,868 \\
\hline 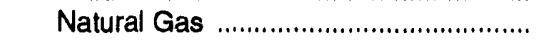 & 3,081 & 2,993 & 2,878 & 3,237 & 3,935 & 4,367 & 7,504 \\
\hline Other Raw Materials ............................... & 2,513 & 2,532 & 2,354 & 1,973 & 2,848 & 2,195 & 2,496 \\
\hline $\begin{array}{l}\text { Total Raw Materials .......................................... } \\
\text { Refined Products }\end{array}$ & 94,763 & 111,406 & 102,435 & 121,762 & 151,756 & 135,942 & 134,868 \\
\hline 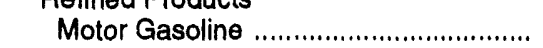 & 7,648 & 9,987 & 10,332 & 11,095 & 13,927 & 12,106 & 12,315 \\
\hline Distillate Fuels ......................................... & 3,299 & 4,393 & 3,642 & 5,274 & 7,006 & 5,738 & 6,008 \\
\hline Other Refined Products ........................... & 5,717 & 7,516 & 6,489 & 8,016 & 10,497 & 9,136 & 9,349 \\
\hline Total Refined Products ......................... & 16,664 & 21,896 & 20,463 & 24,385 & 31,430 & 26,980 & 27,672 \\
\hline \multicolumn{8}{|l|}{ U.S. Production Segment } \\
\hline 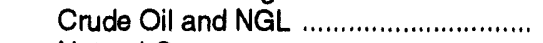 & 1,112 & 1,700 & 1,745 & 2,138 & 2,702 & 4,186 & 2,816 \\
\hline 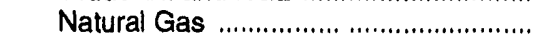 & 2,732 & 2,034 & 2,702 & 2,845 & 3,167 & 3,223 & 4,192 \\
\hline Total Raw Materials ............................... & 3,845 & 3,734 & 4,447 & 4,983 & 5,869 & 7,409 & 7,008 \\
\hline \multicolumn{8}{|l|}{ Sales } \\
\hline \multicolumn{8}{|l|}{$\begin{array}{l}\text { U.S. Refining/Marketing Segment } \\
\text { Raw Materials }\end{array}$} \\
\hline 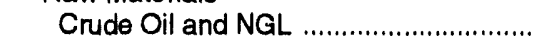 & 35,663 & 43,983 & 46,072 & 55,078 & 69,037 & 64,948 & 63,564 \\
\hline 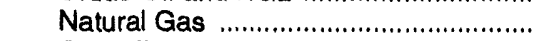 & 2,240 & 2,548 & 2,188 & 2,262 & 3,226 & 3,873 & 7,406 \\
\hline Other Raw Materials ............................... & 992 & 1,490 & 1,509 & 1,084 & 1,271 & 929 & 1,175 \\
\hline $\begin{array}{l}\text { Total Raw Materials ............................. } \\
\text { Refined Products }\end{array}$ & 38,895 & 48,021 & 49,769 & 58,424 & 73,534 & 69,750 & 72,145 \\
\hline 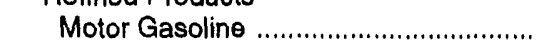 & 54,136 & 60,236 & 60,569 & 65,619 & 77.689 & 68,983 & 67,695 \\
\hline Distillate Fuels ...................................... & 27,342 & 29,737 & 28,529 & 32,675 & 40,695 & 35,535 & 33,920 \\
\hline Other Refined Products ......................... & 21,528 & 24,764 & 21,792 & 23,635 & 26,038 & 23,467 & 22,525 \\
\hline Total Refined Products ........................ & 103,006 & 114,737 & 110,890 & 121,929 & 144,422 & 127,985 & 124,140 \\
\hline \multicolumn{8}{|l|}{ U.S. Production Segment } \\
\hline 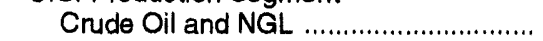 & 28,364 & 32,430 & 27,640 & 30,936 & 38,088 & 32,372 & 29,585 \\
\hline 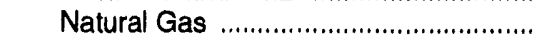 & 14,894 & 12,789 & 15,241 & 14,965 & 15,999 & 14,071 & 16,905 \\
\hline Total Raw Materials ............................... & 43,259 & 45,219 & 42,881 & 45,901 & 54,087 & 46,443 & 46,490 \\
\hline
\end{tabular}

See footnotes at end of table. 
Table B42. U.S. Petroleum Segments Purchases and Sales of Raw Materials and Refined Products for FRS Companies, 1986-1992 (Continued)

\begin{tabular}{|c|c|c|c|c|c|c|c|}
\hline Purchases and Sales & 1986 & 1987 & 1988 & 1989 & 1980 & 1991 & 1992 \\
\hline & \multicolumn{7}{|c|}{ Volumes } \\
\hline \multicolumn{8}{|l|}{$\begin{array}{l}\text { Purchaees } \\
\text { U.S. Refining/Marketing Segment } \\
\text { Raw Materials }\end{array}$} \\
\hline $\begin{array}{l}\text { Crude Oil and NGL (million barrels) .... } \\
\text { Natural Gas (billion cubic feet) }\end{array}$ & $\begin{array}{l}6,332 \\
1,639\end{array}$ & $\begin{array}{l}6,462 \\
1,911\end{array}$ & $\begin{array}{l}7,065 \\
1,726\end{array}$ & $\begin{array}{l}7,031 \\
1,960\end{array}$ & $\begin{array}{l}6,991 \\
2,276\end{array}$ & $\begin{array}{l}6,985 \\
2,884\end{array}$ & $\begin{array}{l}7,176 \\
4,593\end{array}$ \\
\hline $\begin{array}{l}\text { Refined Protucts (million barrels) } \\
\text { Motor Gasoline ................................... } \\
\text { Distillate Fuels ................................. } \\
\text { Other Refined Products ...................... } \\
\text { Total Refined Products .................... }\end{array}$ & $\begin{array}{l}376 \\
157 \\
370 \\
903\end{array}$ & $\begin{array}{r}446 \\
216 \\
371 \\
1,032\end{array}$ & $\begin{array}{r}479 \\
195 \\
383 \\
1,058\end{array}$ & $\begin{array}{r}447 \\
236 \\
442 \\
1,125\end{array}$ & $\begin{array}{r}454 \\
242 \\
399 \\
1,094\end{array}$ & $\begin{array}{r}427 \\
226 \\
407 \\
1,059\end{array}$ & $\begin{array}{r}464 \\
253 \\
413 \\
1,129\end{array}$ \\
\hline $\begin{array}{l}\text { U.S. Production Segment } \\
\text { Crude Oil and NGL (million barrels) .... } \\
\text { Natural Gas (billion cubic feet) ............ }\end{array}$ & $\begin{array}{r}95 \\
1,607\end{array}$ & $\begin{array}{r}152 \\
1,401\end{array}$ & $\begin{array}{r}166 \\
1,761\end{array}$ & $\begin{array}{r}184 \\
1,802\end{array}$ & $\begin{array}{r}177 \\
1,875\end{array}$ & $\begin{array}{r}222 \\
2,067\end{array}$ & $\begin{array}{r}206 \\
2,408\end{array}$ \\
\hline \multicolumn{8}{|l|}{$\begin{array}{l}\text { Sales } \\
\text { U.S. Refining/Marketing Segment } \\
\text { Raw Materials }\end{array}$} \\
\hline $\begin{array}{l}\text { Crude Oil and NGL (million barrels) .... } \\
\text { Natural Gas (billion cubic feet) } \\
\text { Refine.......... }\end{array}$ & $\begin{array}{l}2,336 \\
1,220\end{array}$ & $\begin{array}{l}2,577 \\
1,489\end{array}$ & $\begin{array}{l}3,122 \\
1,310\end{array}$ & $\begin{array}{l}3,226 \\
1,350\end{array}$ & $\begin{array}{l}3,286 \\
1,851\end{array}$ & $\begin{array}{l}3,359 \\
2,457\end{array}$ & $\begin{array}{l}3,572 \\
4,198\end{array}$ \\
\hline 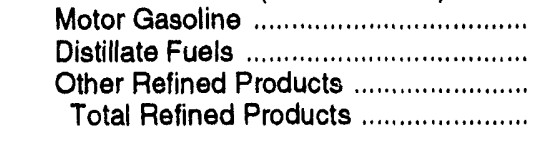 & $\begin{array}{l}2,342 \\
1,321 \\
1,237 \\
4,901\end{array}$ & $\begin{array}{l}2,399 \\
1,355 \\
1,295 \\
5,049\end{array}$ & $\begin{array}{l}2,460 \\
1,411 \\
1,281 \\
5,152\end{array}$ & $\begin{array}{l}2,325 \\
1,361 \\
1,236 \\
4,923\end{array}$ & $\begin{array}{l}2,346 \\
1,372 \\
1,108 \\
4,826\end{array}$ & $\begin{array}{l}2,267 \\
1,347 \\
1,137 \\
4,751\end{array}$ & $\begin{array}{l}2,286 \\
1,364 \\
1,128 \\
4,778\end{array}$ \\
\hline $\begin{array}{l}\text { U.S. Production Segment } \\
\text { Crude Oil and NGL (million barrels) .... } \\
\text { Natural Gas (billion cubic feet) ............ }\end{array}$ & $\begin{array}{l}2,278 \\
7,697\end{array}$ & $\begin{array}{l}2,294 \\
7,811\end{array}$ & $\begin{array}{l}2,347 \\
8,718\end{array}$ & $\begin{array}{l}2,180 \\
8,622\end{array}$ & $\begin{array}{l}2,088 \\
8,979\end{array}$ & $\begin{array}{l}2,078 \\
8,761\end{array}$ & $\begin{array}{l}2,044 \\
9,712\end{array}$ \\
\hline
\end{tabular}

Source: Energy Information Administration, Form ElA-28. 
Table B43. U.S. and Foreign Refining/Marketing Segment, Sources and Dispositions of Crude Oll and Natural Gas Liquids for FRS Companies, 1986-1992

(Million Barrels)

\begin{tabular}{|c|c|c|c|c|c|c|c|}
\hline Sources and Dispositions & 1986 & 1987 & 1988 & 1889 & 1990 & 1991 & 1992 \\
\hline \multicolumn{8}{|l|}{$\begin{array}{l}\text { U.S. Refining/Marketing } \\
\text { Sources }\end{array}$} \\
\hline $\begin{array}{l}\text { Acquisitions from U.S. Production Segment .. } \\
\text { Purchases from Other U.S. Segments .......... } \\
\text { Purchases from Third Parties and }\end{array}$ & $\begin{array}{r}2,105 \\
293\end{array}$ & $\begin{array}{r}2,029 \\
270\end{array}$ & $\begin{array}{r}2,091 \\
424\end{array}$ & $\begin{array}{r}1,943 \\
337\end{array}$ & $\begin{array}{r}1,788 \\
308\end{array}$ & $\begin{array}{r}1,753 \\
309\end{array}$ & $\begin{array}{r}1,745 \\
567\end{array}$ \\
\hline $\begin{array}{l}\text { Unconsolidated Affiliates } \\
\text { Net Transfers from Foreing }\end{array}$ & 3,063 & 3,264 & 3,643 & 3,917 & 3,920 & 4,005 & 3,995 \\
\hline $\begin{array}{c}\text { Refining/Marketing Segment } \\
\text { Total Sources }\end{array}$ & $\begin{array}{r}871 \\
6,332\end{array}$ & $\begin{array}{r}899 \\
6,462\end{array}$ & $\begin{array}{r}906 \\
7,065\end{array}$ & $\begin{array}{r}834 \\
7,031\end{array}$ & $\begin{array}{r}975 \\
6,991\end{array}$ & $\begin{array}{r}918 \\
6,985\end{array}$ & $\begin{array}{r}869 \\
7,176\end{array}$ \\
\hline \multicolumn{8}{|l|}{ Dispositions } \\
\hline 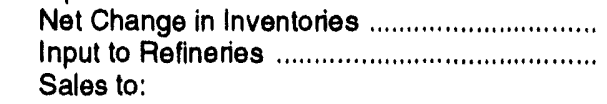 & $\begin{array}{r}-42 \\
4,039\end{array}$ & $\begin{array}{r}-15 \\
3,900\end{array}$ & $\begin{array}{r}.22 \\
3,965\end{array}$ & $\begin{array}{r}15 \\
3,790\end{array}$ & $\begin{array}{r}28 \\
3,678\end{array}$ & $\begin{array}{r}-32 \\
3,658\end{array}$ & $\begin{array}{r}-8 \\
3,611\end{array}$ \\
\hline $\begin{array}{l}\text { Unaffiliated Third Parties ................................ } \\
\text { Other Segments Excluding Foreign }\end{array}$ & 2,181 & 2,528 & 2,734 & 2,849 & 2,957 & 3,040 & 3,171 \\
\hline 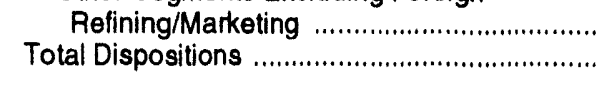 & $\begin{array}{r}154 \\
6,332\end{array}$ & $\begin{array}{r}50 \\
6,462\end{array}$ & $\begin{array}{r}388 \\
7,065\end{array}$ & $\begin{array}{r}377 \\
7,031\end{array}$ & $\begin{array}{r}329 \\
6,991\end{array}$ & $\begin{array}{r}320 \\
6,985\end{array}$ & $\begin{array}{r}401 \\
7,176\end{array}$ \\
\hline \multicolumn{8}{|l|}{$\begin{array}{l}\text { Foreign Refining/Marketing } \\
\text { Sources } \\
\text { Acquisitions from Foreign }\end{array}$} \\
\hline $\begin{array}{l}\text { Production Segment ......................................... } \\
\text { Purchases }\end{array}$ & 1,298 & 1,261 & 1,253 & 1.196 & 1,246 & 1,241 & 1,150 \\
\hline 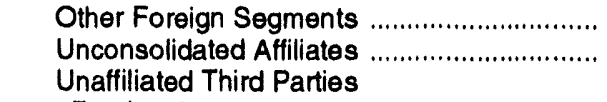 & $\begin{array}{r}41 \\
425\end{array}$ & $\begin{array}{r}68 \\
271\end{array}$ & $\begin{array}{r}49 \\
428\end{array}$ & $\begin{array}{r}22 \\
260\end{array}$ & $\begin{array}{r}28 \\
246\end{array}$ & $\begin{array}{r}61 \\
311\end{array}$ & $\begin{array}{l}77 \\
79\end{array}$ \\
\hline 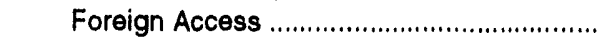 & 134 & 155 & 129 & 156 & 178 & 131 & 111 \\
\hline $\begin{array}{l}\text { Foreign Govemments (Open Market) ......... } \\
\text { Other Unaffiliated Third Parties .................. } \\
\text { Net Transfers to U.S. Refining/ }\end{array}$ & $\begin{array}{r}467 \\
1,187\end{array}$ & $\begin{array}{r}370 \\
1,645\end{array}$ & $\begin{array}{r}374 \\
1,696\end{array}$ & $\begin{array}{r}495 \\
1,900\end{array}$ & $\begin{array}{r}690 \\
1,903\end{array}$ & $\begin{array}{r}580 \\
1,972\end{array}$ & $\begin{array}{r}774 \\
1,885\end{array}$ \\
\hline $\begin{array}{l}\text { Marketing Segment } \\
\text { Total Sources }\end{array}$ & $\begin{array}{r}-871 \\
2,682\end{array}$ & $\begin{array}{r}.899 \\
2,870\end{array}$ & $\begin{array}{r}-906 \\
3,023\end{array}$ & $\begin{array}{r}-834 \\
3,194\end{array}$ & $\begin{array}{r}-975 \\
3,315\end{array}$ & $\begin{array}{r}-918 \\
3,379\end{array}$ & $\begin{array}{r}-869 \\
3,207\end{array}$ \\
\hline \multicolumn{8}{|l|}{ Dispositions } \\
\hline Net Change in Inventories & 60 & 3 & 1 & -13 & 12 & -4 & -8 \\
\hline 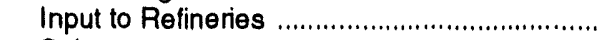 & 1,200 & 1,326 & 1,401 & 1,346 & 1,361 & 1,508 & 1,367 \\
\hline 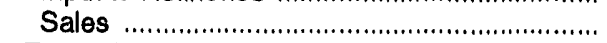 & 1,422 & 1,541 & 1,620 & 1,861 & 1,942 & 1,874 & 1,849 \\
\hline 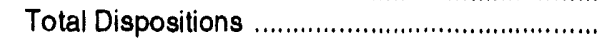 & 2,682 & 2,870 & 3,023 & 3,194 & 3,315 & 3,379 & 3,207 \\
\hline
\end{tabular}

Source: Energy Information Administration, Form ElA-28. 
Table B44. U.S. and Foreign Oil Raw Materials Balance for FRS Companies Ranked by Total Energy Assets, 1990-1992

(Million Barrels)

\begin{tabular}{|c|c|c|c|c|c|}
\hline \multirow[b]{2}{*}{ Geographical Sector } & \multicolumn{4}{|c|}{ Raw Materlal Acquisitions } & \multirow[b]{2}{*}{$\begin{array}{c}\text { Total } \\
\text { Reflnery } \\
\text { Input }\end{array}$} \\
\hline & $\begin{array}{l}\text { Direct } \\
\text { Oll } \\
\text { Access } 1\end{array}$ & $\begin{array}{c}\text { Not } \\
\text { Oil } \\
\text { Purchases } 2\end{array}$ & $\begin{array}{c}\text { Net } \\
\text { Oll } \\
\text { Imports }\end{array}$ & $\begin{array}{c}\text { Oll } \\
\text { Stock } \\
\text { Changes }\end{array}$ & \\
\hline \multicolumn{6}{|l|}{$\begin{array}{l}\text { United States } \\
\text { All FRS }\end{array}$} \\
\hline 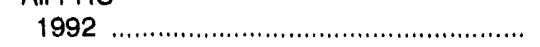 & $2,108.3$ & 626.5 & 868.8 & 7.7 & $3,611,4$ \\
\hline 1991 & $1,891.2$ & 816.7 & 917.9 & 32.4 & $3,658.3$ \\
\hline 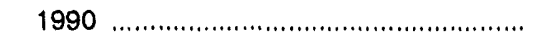 & $1,918.8$ & 811.3 & 975.2 & -27.5 & $3,677.7$ \\
\hline \multicolumn{6}{|l|}{ Top Four } \\
\hline 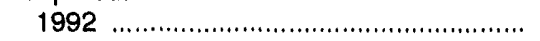 & 675.3 & 273.0 & 316.3 & 5.5 & $1,270.2$ \\
\hline 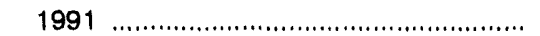 & 695.8 & 226.2 & 317.1 & 9.4 & $1,248.5$ \\
\hline 1990 & 706.4 & 227.2 & 317.7 & 0.6 & $1,251.9$ \\
\hline \multicolumn{6}{|l|}{ Five Through Twelve } \\
\hline 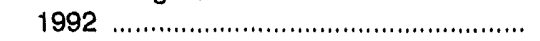 & $1,087.9$ & 154.1 & 186.6 & -7.7 & $1,420.9$ \\
\hline 1991 & 884.4 & 405.6 & 301.1 & 36.1 & $1,627.1$ \\
\hline $1990 \ldots \ldots \ldots$ & 925.6 & 426.3 & 266.1 & -6.4 & $1,611.6$ \\
\hline \multicolumn{6}{|l|}{ All Other } \\
\hline 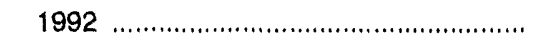 & 345.2 & 199.4 & 365.8 & 9.9 & 920.3 \\
\hline 1991 & 311.1 & 185.0 & 299.7 & -13.0 & 782.7 \\
\hline 1990 & 286.9 & 157.8 & 391.4 & -21.7 & 814.3 \\
\hline \multicolumn{6}{|l|}{$\begin{array}{l}\text { Forelgn } \\
\text { All FRS }\end{array}$} \\
\hline 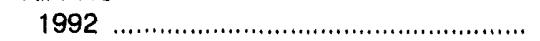 & $1,225.9$ & $1,001.7$ & -868.8 & 8.3 & $1,367,2$ \\
\hline 1991 & $1,560.2$ & 862.2 & -917.9 & 3.9 & $1,508.3$ \\
\hline 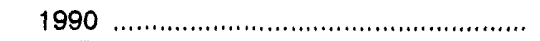 & $1,468.7$ & 879.1 & -975.2 & .11 .9 & $1,360.7$ \\
\hline \multicolumn{6}{|l|}{ Top Four } \\
\hline 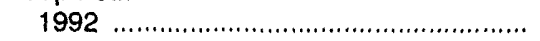 & 654.7 & 886.1 & -316.3 & -2.1 & $1,222.3$ \\
\hline 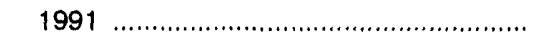 & 962.5 & 707.9 & -317.1 & -2.1 & $1,351.2$ \\
\hline 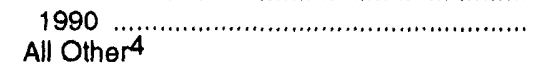 & 952.1 & 614.1 & -317.7 & -18.5 & $1,230.0$ \\
\hline 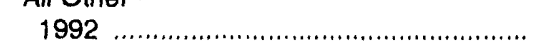 & 571.3 & 115.6 & -552.5 & 10.4 & 144.8 \\
\hline 1991 & 597.6 & 154.2 & .600 .8 & 6.0 & 157.1 \\
\hline 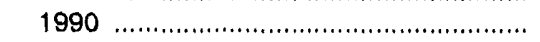 & 516.6 & 265.0 & -657.5 & 6.6 & 130.7 \\
\hline
\end{tabular}

1 Ownership interest production plus purchases from other company segments and from unconsolidated affiliates of crude oil and natural gas liquids (domestic and foreign areas) plus foreign access oil (foreign area only). Foreign access represents acquisitions from foreign entities, for which reporting firms act as producers under long-term contract.

2 Purchases of crude and natural gas liquids (except imports) on the open market or from unaffiliated third parties less oil sales to unaffiliated third parties.

3 Positive number indicates stock withdrawal (addition to supply).

4 The 'Five Through Twelve' and 'All Other' groups combined into foreign 'All Other' to prevent disclosure.

Source: Energy Information Administration, Form ElA-28. 
Table B45. U.S. Rofinery Output and Refinery Capacity Statistics for FRS Companies, Ranked by Total Enorgy Aseoto, and for U.S. Industry, 1891 and 1992

(Thousand Barrels per Day)

\begin{tabular}{|c|c|c|c|c|c|c|}
\hline \multirow[b]{2}{*}{ Rofined Produot statietice 1} & \multicolumn{4}{|c|}{ FRs Companice } & \multirow[b]{2}{*}{$\begin{array}{l}\text { U.S. } \\
\text { Induatry }\end{array}$} & \multirow[b]{2}{*}{$\begin{array}{l}\text { FRS Percent } \\
\text { of Industry }\end{array}$} \\
\hline & $\underset{\text { FAl }}{\text { All }}$ & $\begin{array}{l}\text { Top } \\
\text { Four }\end{array}$ & $\begin{array}{c}\text { Flve Through } \\
\text { Twelve }\end{array}$ & $\begin{array}{l}\text { All } \\
\text { Other }\end{array}$ & & \\
\hline \multicolumn{7}{|l|}{1992} \\
\hline 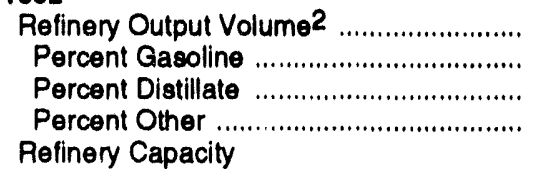 & $\begin{array}{r}10,994 \\
45.2 \\
26.7 \\
28.2\end{array}$ & $\begin{array}{r}4,057 \\
44.4 \\
25.7 \\
29.9\end{array}$ & $\begin{array}{r}4,337 \\
47.5 \\
27.1 \\
25.5\end{array}$ & $\begin{array}{r}2,600 \\
42.7 \\
27.5 \\
29.9\end{array}$ & $\begin{array}{r}15,932 \\
45.2 \\
27.6 \\
27.3\end{array}$ & $\begin{array}{l}69.0 \\
69.0 \\
66.8 \\
71.3\end{array}$ \\
\hline 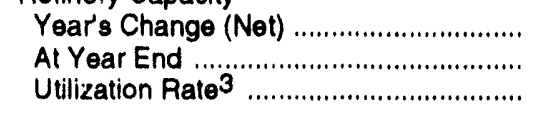 & $\begin{array}{r}-251 \\
10,952 \\
87.8\end{array}$ & $\begin{array}{r}.96 \\
3,764 \\
88.5\end{array}$ & $\begin{array}{r}-506 \\
4,155 \\
88.9\end{array}$ & $\begin{array}{r}351 \\
3,033 \\
85.4\end{array}$ & $\begin{array}{r}-648 \\
15,804 \\
85.6\end{array}$ & $\begin{array}{r}38.7 \\
(49.3\end{array}$ \\
\hline \multicolumn{7}{|l|}{1991} \\
\hline 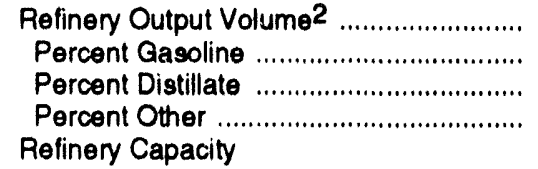 & $\begin{array}{r}11,122 \\
45.5 \\
26.6 \\
28.0\end{array}$ & $\begin{array}{r}4,031 \\
45.1 \\
25.5 \\
29.4\end{array}$ & $\begin{array}{r}4,807 \\
45.3 \\
26.5 \\
28.2\end{array}$ & $\begin{array}{r}2,284 \\
46.3 \\
28.5 \\
25.1\end{array}$ & $\begin{array}{r}15,872 \\
45.0 \\
27.8 \\
27.2\end{array}$ & $\begin{array}{l}70.1 \\
70.8 \\
67.0 \\
72.0\end{array}$ \\
\hline 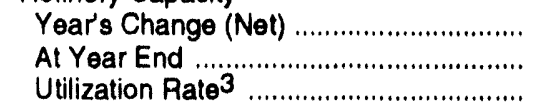 & $\begin{array}{r}-169 \\
11,203 \\
87.2\end{array}$ & $\begin{array}{r}-38 \\
3,860 \\
85.8\end{array}$ & $\begin{array}{r}-151 \\
4,661 \\
92.3\end{array}$ & $\begin{array}{r}20 \\
2,682 \\
80.4\end{array}$ & $\begin{array}{r}22 \\
16,453 \\
83.5\end{array}$ & $\begin{array}{r}-768.2 \\
68.1 \\
(4)\end{array}$ \\
\hline
\end{tabular}

1 U.S. FRS and U.S. industry data include operations in Puerto Rico and the U.S. Virgin Islands.

2 For FRS companies, includes refinery output at own refineries for own account and at others' refineries for own account.

3 Defined as average daily crude runs at own refineries, for own account and for account of others, divided by average daily crude distillation capacity.

4 Not meaningful.

Note: Sum of components may not equal total due to independent rounding.

Sources: Industry data - Refinery output and refinery capacity: Energy Information Administration, Forms EIA-820 and ElA-810, see

Petroleum Supply Annual, 1991 and 1992. FRS companies data - Energy Information Administration, Form ElA-28. 
Table B46. Foreign Refinery Output and Refinery Capacity Statistics for FRS Companies, Ranked by Total Energy Assets, and for Foreign Industry, 1991 and 1992

(Thousand Barrels per Day)

\begin{tabular}{|c|c|c|c|c|c|}
\hline \multirow[b]{2}{*}{ Refined Product Statietice 1} & \multicolumn{3}{|c|}{ FAS Companies } & \multirow[b]{2}{*}{$\begin{array}{l}\text { Forelgn } \\
\text { Industry }\end{array}$} & \multirow[b]{2}{*}{$\begin{array}{l}\text { FRS Percent } \\
\text { of Industry }\end{array}$} \\
\hline & $\begin{array}{c}\text { All } \\
\text { FRS }\end{array}$ & $\begin{array}{l}\text { Top } \\
\text { Four }\end{array}$ & $\underset{\text { Other2 }}{\text { All }}$ & & \\
\hline \multicolumn{6}{|l|}{1992} \\
\hline Refinery Output Volume ${ }^{3}$.. & 4,465 & 3,994 & 471 & - & $(4)$ \\
\hline 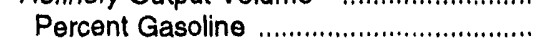 & 29.0 & 28.8 & 31.0 & - & $(4)$ \\
\hline 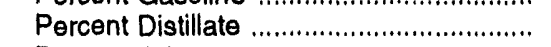 & 42.8 & 42.4 & 46.7 & - & $(4)$ \\
\hline 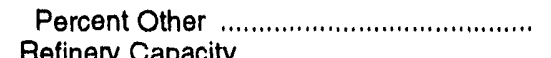 & 28.1 & 28.8 & 22.3 & - & $(4)$ \\
\hline \multicolumn{6}{|l|}{ Refinery Capacity } \\
\hline & 26 & 26 & $\begin{aligned} 0 \\
0\end{aligned}$ & 413 & 6.3 \\
\hline $\begin{array}{l}\text { At Year End } \\
\text { Utilization Rate }{ }^{5}\end{array}$ & $\begin{array}{l}4,648 \\
80.0\end{array}$ & $\begin{array}{l}4,255 \\
770\end{array}$ & 393 & 43,011 & $\left(4^{10.8}\right.$ \\
\hline \multicolumn{6}{|l|}{1991} \\
\hline Refinery Output Volume ${ }^{3}$. & 4,330 & 3,904 & 426 & 36,560 & 11.8 \\
\hline Percent Gasoline & 29.7 & 29.3 & $\begin{array}{l}420 \\
33.1\end{array}$ & 21.1 & 16.6 \\
\hline Percent Distillate ........................................... & 42.4 & 42.5 & 41.3 & 38.6 & 13.0 \\
\hline 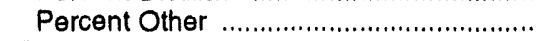 & 27.9 & 28.2 & 25.6 & 40.2 & 8.2 \\
\hline \multicolumn{6}{|l|}{ Refinery Capacity } \\
\hline Year's Change (net) ................................. & 118 & 118 & 0 & 1,178 & 10.0 \\
\hline 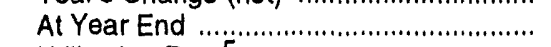 & 4,622 & 4,229 & 393 & 42,598 & 10.9 \\
\hline 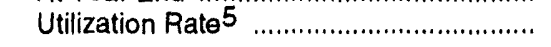 & 80.4 & 78.6 & 98.7 & - & $\left({ }^{4}\right)$ \\
\hline
\end{tabular}

1 Foreign FRS and foreign industry data exclude operations in Puerto Rico and the U.S. Virgin Islands, as well as China and the former Soyiet Bloc.

2 'Five through Twelve' and 'All Other' groups combined to avoid disclosure.

3 For FRS companies, includes refinery output at own refineries for own account and at others' refineries for own account.

4 Not meaningful.

5 Defined as average daily crude runs at own refineries, for own account and for account of others, divided by average daily crude distillation capacity.

- Not available

Note: Sum of components may not equal total due to independent rounding.

Sources: Industry data - Energy Information Administration, Intemational Energy Annual, 1991 and 1992. FRS companies data - Energy Information Administration, Form ElA-28. 
Table B47. U.S. and Foreign Petroleum Refining Statistics for FRS Companies, 1986-1992

\begin{tabular}{|c|c|c|c|c|c|c|c|}
\hline Rofining Statiotice & 1986 & 1987 & 1888 & 1989 & 1990 & 1991 & 1992 \\
\hline & \multicolumn{7}{|c|}{ (thousand barrels per calendar day) } \\
\hline 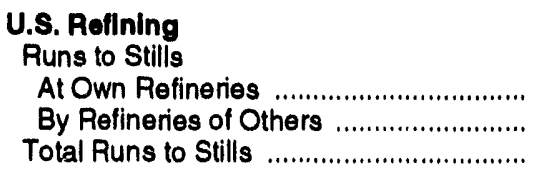 & $\begin{array}{r}10,664 \\
60 \\
10,724\end{array}$ & $\begin{array}{r}10,536 \\
50 \\
10,586\end{array}$ & $\begin{array}{r}10,646 \\
11 \\
10,657\end{array}$ & $\begin{array}{r}10,147 \\
4 \\
10,151\end{array}$ & $\begin{array}{r}9,922 \\
4 \\
9,926\end{array}$ & $\begin{array}{r}9,847 \\
5 \\
9,852\end{array}$ & $\begin{array}{r}9,736 \\
5 \\
9,741\end{array}$ \\
\hline 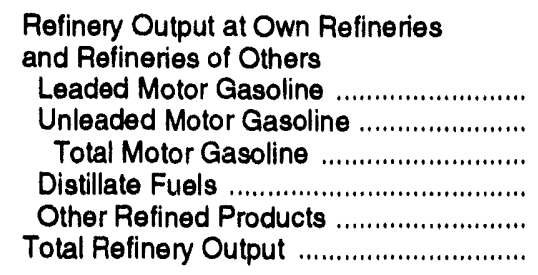 & $\begin{array}{r}1,532 \\
3,755 \\
5,287 \\
2,947 \\
3,225 \\
11,459\end{array}$ & $\begin{array}{r}1,252 \\
4,024 \\
5,276 \\
3,175 \\
3,261 \\
11,712\end{array}$ & $\begin{array}{r}936 \\
4,424 \\
5,360 \\
3,020 \\
3,653 \\
12,033\end{array}$ & $\begin{array}{r}523 \\
4,579 \\
5,102 \\
2,827 \\
3,484 \\
11,413\end{array}$ & $\begin{array}{r}256 \\
4,754 \\
5,010 \\
2,866 \\
3,436 \\
11,312\end{array}$ & $\begin{array}{r}378 \\
4,677 \\
5,055 \\
2,954 \\
3,113 \\
11,122\end{array}$ & $\begin{array}{r}251 \\
4,717 \\
4,968 \\
2,931 \\
3,095 \\
10,994\end{array}$ \\
\hline \multirow[t]{2}{*}{ Refinery Capacity at End of Year ............ } & 12,526 & 12,462 & 12,281 & 11,489 & 11,372 & 11,203 & 10,952 \\
\hline & \multicolumn{7}{|c|}{ (number of refineries) } \\
\hline \multirow[t]{2}{*}{ Number of Wholly Owned Refineries .... } & 94 & 91 & 91 & 89 & 89 & 88 & 82 \\
\hline & \multicolumn{7}{|c|}{ (thousand barrels per calendar day) } \\
\hline 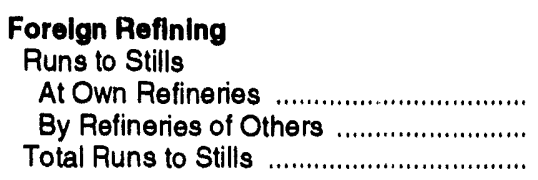 & $\begin{array}{r}3,268 \\
644 \\
3,912\end{array}$ & $\begin{array}{r}3,346 \\
709 \\
4,055\end{array}$ & $\begin{array}{r}3,565 \\
836 \\
4,401\end{array}$ & $\begin{array}{r}3,492 \\
685 \\
4,177\end{array}$ & $\begin{array}{r}3,575 \\
717 \\
4,292\end{array}$ & $\begin{array}{r}3,667 \\
632 \\
4,299\end{array}$ & $\begin{array}{r}3,706 \\
749 \\
4,455\end{array}$ \\
\hline 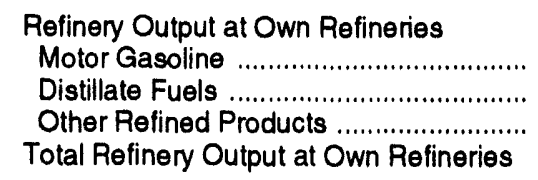 & $\begin{array}{l}1,001 \\
1,290 \\
1,163 \\
3,454\end{array}$ & $\begin{array}{l}1,011 \\
1,404 \\
1,224 \\
3,639\end{array}$ & $\begin{array}{l}1,078 \\
1,496 \\
1,262 \\
3,836\end{array}$ & $\begin{array}{l}1,044 \\
1,459 \\
1,196 \\
3,699\end{array}$ & $\begin{array}{l}1,084 \\
1,431 \\
1,075 \\
3,590\end{array}$ & $\begin{array}{l}1,097 \\
1,534 \\
1,009 \\
3,640\end{array}$ & $\begin{array}{l}1,098 \\
1,553 \\
1,064 \\
3,715\end{array}$ \\
\hline 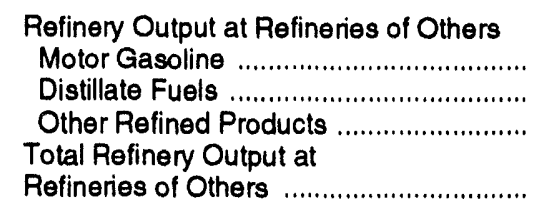 & $\begin{array}{l}209 \\
240 \\
193 \\
\\
642\end{array}$ & $\begin{array}{l}229 \\
276 \\
204\end{array}$ & $\begin{array}{l}270 \\
335 \\
250\end{array}$ & $\begin{array}{l}218 \\
305 \\
206\end{array}$ & $\begin{array}{l}208 \\
315 \\
199\end{array}$ & $\begin{array}{l}188 \\
303 \\
199\end{array}$ & $\begin{array}{l}199 \\
359 \\
192\end{array}$ \\
\hline 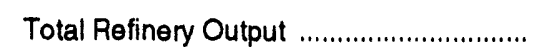 & 4,096 & 4,348 & 4,691 & 4,428 & 4,312 & 4,330 & 4,465 \\
\hline \multirow[t]{2}{*}{ Refinery Capacity at End of Year ............ } & 4,638 & 4,525 & 4,508 & 4,414 & 4,504 & 4,622 & 4,648 \\
\hline & \multicolumn{7}{|c|}{ (number of refineries) } \\
\hline Number of Wholly Owned Refineries .... & 34 & 32 & 31 & 28 & 25 & 27 & 27 \\
\hline Number of Partially Owned Refinerles .. & 16 & 16 & 16 & 18 & 17 & 15 & 14 \\
\hline
\end{tabular}

Source: Energy Information Administration, Form EIA-28. 
Table B48. U.S. Refining/Marketing Revenues and Costs for FRS Companles, 1990-1992

\begin{tabular}{|c|c|c|c|c|c|c|}
\hline \multirow{2}{*}{ Revenues and Coste } & \multicolumn{3}{|c|}{ Million Dollare } & \multicolumn{3}{|c|}{ Percent of Produot Aovenues } \\
\hline & 1990 & 1991 & 1992 & 1980 & 1991 & 1902 \\
\hline Refined Product Revenues ...................... & $144,422.0$ & $127,985.0$ & $124,140.0$ & 100.0 & 100.0 & 100.0 \\
\hline 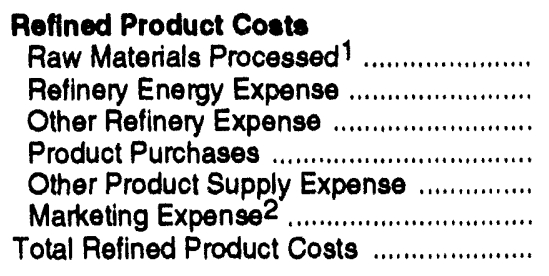 & $\begin{array}{r}78,412.0 \\
5,461.0 \\
9,026.0 \\
31,430.0 \\
4,582.0 \\
9,840.0 \\
138,751.0\end{array}$ & $\begin{array}{r}67,364.0 \\
5,544.0 \\
9,053.0 \\
26,980.0 \\
4,097.0 \\
11,440.0 \\
124,478.0\end{array}$ & $\begin{array}{r}63,629.0 \\
5,363.0 \\
9,040.0 \\
27,672.0 \\
3,739.0 \\
12,895.0 \\
122,338.0\end{array}$ & $\begin{array}{r}54.3 \\
3.8 \\
6.2 \\
21.8 \\
3.2 \\
6.8 \\
66.1\end{array}$ & $\begin{array}{r}52.6 \\
4.3 \\
7.1 \\
21.1 \\
3.2 \\
8.9 \\
97.3\end{array}$ & $\begin{array}{r}51.3 \\
4.3 \\
7.3 \\
22.3 \\
3.0 \\
10.4 \\
98.5\end{array}$ \\
\hline 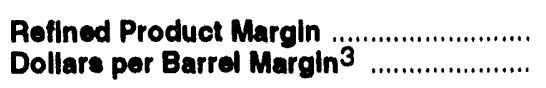 & $\begin{array}{r}5,671.0 \\
1.18\end{array}$ & $\begin{array}{r}3,507.0 \\
0.74\end{array}$ & $\begin{array}{r}1,802.0 \\
0.38\end{array}$ & $\begin{array}{l}3.9 \\
-\cdot\end{array}$ & $\begin{array}{l}2.7 \\
--\end{array}$ & $\begin{array}{l}1.5 \\
. \cdot\end{array}$ \\
\hline Other Refining/Marketing Revenuee 4 ... & $8,012.0$ & $9,861.0$ & $10,007.0$ & .. & -. & 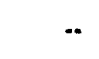 \\
\hline 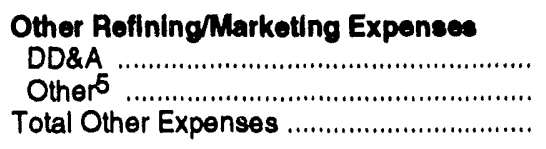 & $\begin{array}{r}2,967.0 \\
7,600.0 \\
10,567.0\end{array}$ & $\begin{array}{r}3,270.0 \\
8,736.0 \\
12,006.0\end{array}$ & $\begin{array}{r}3,532.0 \\
8,151.0 \\
11,683.0\end{array}$ & $\begin{array}{l}\ddot{.} \\
. .\end{array}$ & $\begin{array}{l}. . \\
. . \\
. .\end{array}$ & $\begin{array}{l}\ddot{.} \\
\ddot{.}\end{array}$ \\
\hline RofiningMarkoting Operating Income .. & $3,116.0$ & $1,362.0$ & 126.0 & -- & -. & $\cdots$ \\
\hline Miscellaneous Revenue Expense 6 .... & 398.0 & 150.0 & -115.0 & .. & .. & $\cdots$ \\
\hline 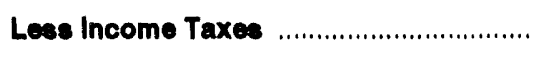 & $1,330.0$ & 609.0 & 217.0 & -. & -. & $\cdots$ \\
\hline Refining/Marketing Net income .............. & $2,184.0$ & 903.0 & .213 .0 & -. & $\cdots$ & $\cdots$ \\
\hline
\end{tabular}

1 Represents reported cost of raw materials processed at refineries, less any profit from raw material trades or exchanges by refining/marketing.

2 Excludes cost of marketing tires, batteries, and accessories (TBA)

3 Dollars per barrel of refined product sold.

4 Includes revenues from transportation services supplied (non-federally regulated), TBA sales and miscellaneous.

5 Includes general and administrative expenses, research and development costs, costs of transportation services supplied to others not included in raw material costs, and expenses for TBA.

6 Includes other revenue and expense items, extraordinary items, and cumulative effect of accounting changes.

- Not applicable.

Source: Energy Information Administration, Form ElA-28. 
Table B49. Sources of U.S. Bltuminous Coal and Llgnite Production, by Rogion and Mining Mothod, for FRS Companies and U.8. Industry, 1902 and Porcont Change From 1901

\begin{tabular}{|c|c|c|c|c|c|c|}
\hline \multirow{2}{*}{ Produotion } & \multirow{2}{*}{ Total } & \multicolumn{3}{|c|}{ Reglon } & \multicolumn{2}{|c|}{ Mining Mothod } \\
\hline & & Enat & Mldwest & Woot & Undorground & Surface \\
\hline \multirow{3}{*}{ 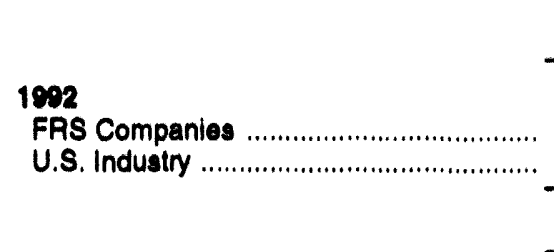 } & \multicolumn{6}{|c|}{ (million tone) } \\
\hline & $\begin{array}{l}251.8 \\
997.5\end{array}$ & $\begin{array}{r}75.4 \\
456.6\end{array}$ & $\begin{array}{r}22.8 \\
132.0\end{array}$ & $\begin{array}{l}153.7 \\
409.0\end{array}$ & $\begin{array}{r}83.8 \\
407.2\end{array}$ & $\begin{array}{l}168.1 \\
590.3\end{array}$ \\
\hline & \multicolumn{6}{|c|}{ (percent) } \\
\hline 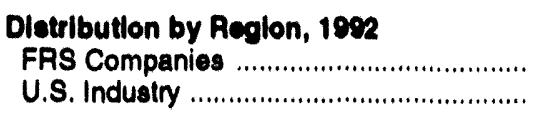 & $\begin{array}{l}100.0 \\
100.0\end{array}$ & $\begin{array}{l}29.9 \\
45.8\end{array}$ & $\begin{array}{r}9.0 \\
13.2\end{array}$ & $\begin{array}{l}61.0 \\
41.0\end{array}$ & $\ddot{.}$ & $\ddot{. .}$ \\
\hline 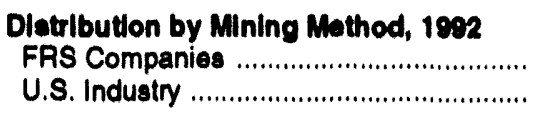 & $\begin{array}{l}100.0 \\
100.0\end{array}$ & $\ddot{. .}$ & $\begin{array}{l}. . \\
. .\end{array}$ & $\begin{array}{l}. . \\
.-\end{array}$ & $\begin{array}{l}33.3 \\
40.8\end{array}$ & $\begin{array}{l}66.7 \\
59.2\end{array}$ \\
\hline $\begin{array}{l}\text { FRS Companies as a rercent } \\
\text { of U.8. Industry }\end{array}$ & 25.3 & 16.5 & 17.2 & 37.6 & 20.6 & 28.5 \\
\hline 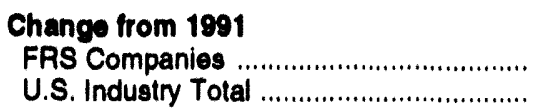 & $\begin{array}{r}-13.0 \\
0.2\end{array}$ & $\begin{array}{r}.33 .9 \\
.0 .3\end{array}$ & $\begin{array}{r}-13.0 \\
-1.1\end{array}$ & $\begin{array}{l}2.9 \\
1.1\end{array}$ & $\begin{array}{r}-31.8 \\
0.0\end{array}$ & $\begin{array}{l}0.8 \\
0.3\end{array}$ \\
\hline
\end{tabular}

.$=$ Not applicable.

Sources: Industry data - Energy Information Administration Form EIA.7A, see Coal Production 1992 (October 1993). FRS companies data - Energy Information Administration, Form EIA-28. 
Table B50. U.S. Coal Reserves Balance for FRS Companies, 1986-1992 (Million Tons)

\begin{tabular}{|c|c|c|c|c|c|c|c|}
\hline Reserves Balance & 1986 & 1987 & 1988 & 1989 & 1990 & 1991 & 1992 \\
\hline $\begin{array}{l}\text { Changes to U.S. Coal Reserves } \\
\text { Beginning of Period ................................... } \\
\text { Changes due to: }\end{array}$ & 54,153 & 49,629 & 54,595 & 51,710 & 49,200 & 44,949 & 39,026 \\
\hline 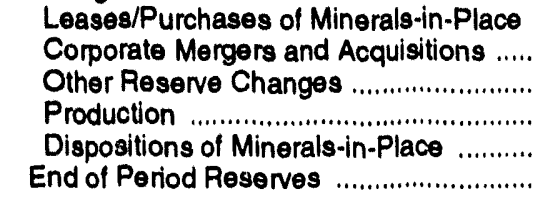 & $\begin{array}{r}119 \\
672 \\
-139 \\
-228 \\
-4,924 \\
49,653\end{array}$ & $\begin{array}{r}304 \\
764 \\
6,505 \\
-255 \\
-2,352 \\
54,595\end{array}$ & $\begin{array}{r}521 \\
W \\
W \\
-285 \\
-653 \\
53,067\end{array}$ & $\begin{array}{r}417 \\
W \\
W \\
-287 \\
-793 \\
49,200\end{array}$ & $\begin{array}{r}654 \\
W \\
W \\
-282 \\
-4,002 \\
44,948\end{array}$ & $\begin{array}{r}-1 C 7 \\
W \\
W \\
-290 \\
-7,824 \\
38,219\end{array}$ & $\begin{array}{r}571 \\
W \\
W \\
-252 \\
-18,576 \\
20,787\end{array}$ \\
\hline 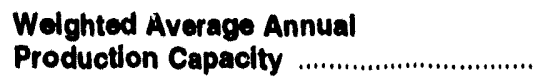 & 283 & 303 & 313 & 322 & 320 & 327 & 291 \\
\hline
\end{tabular}

$W=$ Data withheld to avoid disclosure.

Source: Energy Information Administration, Form ElA-28. 
Table B51. L'S. Coal Reserves (End of Year) and Production Statistics for FRS Cumpanies, 1986-1992 (Million Tons)

\begin{tabular}{|c|c|c|c|c|c|c|}
\hline \multirow{2}{*}{ Reserves and Production Statistics } & \multirow{2}{*}{$\begin{array}{l}\text { U.S. } \\
\text { Total }\end{array}$} & \multicolumn{3}{|c|}{ Region } & \multicolumn{2}{|c|}{ Mining Mothod } \\
\hline & & East & Midwest & West & Underground & Surface \\
\hline \multicolumn{7}{|l|}{1986} \\
\hline 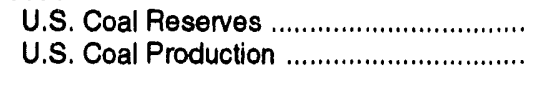 & $\begin{array}{r}49,653.3 \\
227.6\end{array}$ & $\begin{array}{r}8,998.8 \\
84.3\end{array}$ & $\begin{array}{r}7,449.0 \\
41.7\end{array}$ & $\begin{array}{r}33,205.5 \\
101.9\end{array}$ & $\begin{array}{r}16,736.0 \\
101.6\end{array}$ & $\begin{array}{r}32,917.3 \\
126.0\end{array}$ \\
\hline \multicolumn{7}{|l|}{1987} \\
\hline $\begin{array}{l}\text { U.S. Coal Reserves } \\
\text { U.S. Coal Production }\end{array}$ & $\begin{array}{r}54,595.2 \\
255.3\end{array}$ & $\begin{array}{r}13,069.2 \\
98.3\end{array}$ & $\begin{array}{r}7,371.2 \\
41.7\end{array}$ & $\begin{array}{r}34,154.8 \\
115.3\end{array}$ & $\begin{array}{r}16,549.5 \\
114.5\end{array}$ & $\begin{array}{r}38,045.7 \\
140.8\end{array}$ \\
\hline \multicolumn{7}{|l|}{1988} \\
\hline $\begin{array}{l}\text { U.S. Coal Reserves } \\
\text { U.S. Coal Production }\end{array}$ & $\begin{array}{r}53,067.2 \\
285.3\end{array}$ & $\begin{array}{r}12,656.0 \\
108.5\end{array}$ & $\begin{array}{r}7,256.2 \\
38.8\end{array}$ & $\begin{array}{r}33,154.9 \\
138.0\end{array}$ & $\begin{array}{r}16,287.1 \\
124.8\end{array}$ & $\begin{array}{r}36,780.1 \\
160.5\end{array}$ \\
\hline \multicolumn{7}{|l|}{1989} \\
\hline 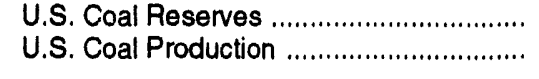 & $\begin{array}{r}49,200.2 \\
286.9\end{array}$ & $\begin{array}{r}11,462.1 \\
114.0\end{array}$ & $\begin{array}{r}7,324.2 \\
37.7\end{array}$ & $\begin{array}{r}30,413.9 \\
135.1\end{array}$ & $\begin{array}{r}15,783.7 \\
123.9\end{array}$ & $\begin{array}{r}32,416.4 \\
163.0\end{array}$ \\
\hline \multicolumn{7}{|l|}{1990} \\
\hline $\begin{array}{l}\text { U.S. Coal Reserves } \\
\text { U.S. Coal Production }\end{array}$ & $\begin{array}{r}44,948.5 \\
282.0\end{array}$ & $\begin{array}{r}8,864.7 \\
118.8\end{array}$ & $\begin{array}{r}6,812.0 \\
25.5\end{array}$ & $\begin{array}{r}29,271.9 \\
137.8\end{array}$ & $\begin{array}{r}14,865.6 \\
119.4\end{array}$ & $\begin{array}{r}30,082.9 \\
162.7\end{array}$ \\
\hline \multicolumn{7}{|l|}{1991} \\
\hline 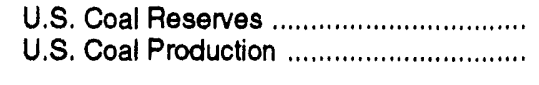 & $\begin{array}{r}38,218.9 \\
289.6\end{array}$ & $\begin{array}{r}4,802.1 \\
114.1\end{array}$ & $\begin{array}{r}5,653.1 \\
26.2\end{array}$ & $\begin{array}{r}27,763.7 \\
149.4\end{array}$ & $\begin{array}{r}10,136.4 \\
122.8\end{array}$ & $\begin{array}{r}28,082.5 \\
166.8\end{array}$ \\
\hline \multicolumn{7}{|l|}{1992} \\
\hline 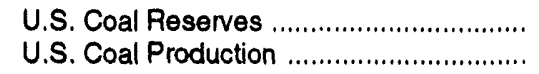 & $\begin{array}{r}20,787.2 \\
251.9\end{array}$ & $\begin{array}{r}4,190.0 \\
75.4\end{array}$ & $\begin{array}{r}4,733.3 \\
22.8\end{array}$ & $\begin{array}{r}11,863.9 \\
153.7\end{array}$ & $\begin{array}{r}8,127.0 \\
83.8\end{array}$ & $\begin{array}{r}12,660.3 \\
168.1\end{array}$ \\
\hline
\end{tabular}

Source: Energy Information Administration, Form ElA-28. 
Table B52. Research and Development Expenditures for FRS Companies, 1986-1992 (Million Dollars)

\begin{tabular}{|c|c|c|c|c|c|c|c|}
\hline $\begin{array}{c}\text { Research and Development } \\
\text { Expenditures }\end{array}$ & 1986 & 1987 & 1988 & 1989 & 1990 & 1991 & 1992 \\
\hline $\begin{array}{l}\text { Sources of R\&D Funds } \\
\text { Federal Govemment } \\
\text { Internal Company } \\
\text { Other Sources } \\
\text { Total Sources }\end{array}$ & $\begin{array}{r}15 \\
3,554 \\
11 \\
3,581\end{array}$ & $\begin{array}{r}17 \\
3,451 \\
20 \\
3,488\end{array}$ & $\begin{array}{r}14 \\
3,667 \\
18 \\
3,699\end{array}$ & $\begin{array}{r}11 \\
3,664 \\
28 \\
3,703\end{array}$ & $\begin{array}{r}11 \\
3,843 \\
49 \\
3,903\end{array}$ & $\begin{array}{r}14 \\
3,832 \\
56 \\
3,902\end{array}$ & $\begin{array}{r}22 \\
3,590 \\
60 \\
3,672\end{array}$ \\
\hline 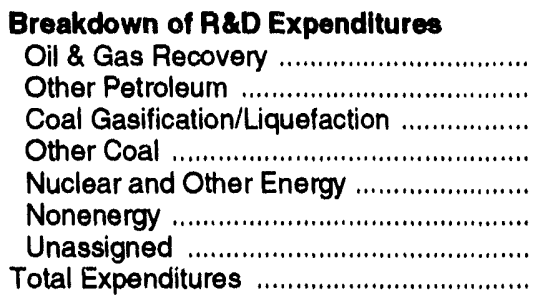 & $\begin{array}{r}645 \\
496 \\
69 \\
21 \\
170 \\
2,055 \\
125 \\
3,581\end{array}$ & $\begin{array}{r}666 \\
463 \\
47 \\
17 \\
91 \\
2,166 \\
38 \\
3,488\end{array}$ & $\begin{array}{r}726 \\
496 \\
34 \\
18 \\
85 \\
2,307 \\
33 \\
3,699\end{array}$ & $\begin{array}{r}694 \\
575 \\
W \\
W \\
93 \\
9,148 \\
2,142 \\
3,703\end{array}$ & $\begin{array}{r}727 \\
615 \\
38 \\
15 \\
116 \\
2,274 \\
118 \\
3,903\end{array}$ & $\begin{array}{r}794 \\
678 \\
39 \\
17 \\
95 \\
2,159 \\
120 \\
3,902\end{array}$ & $\begin{array}{r}768 \\
652 \\
W \\
W \\
80 \\
2,041 \\
117 \\
3,672\end{array}$ \\
\hline
\end{tabular}

$W=$ Data withheld to avoid disclosure.

Source: Energy Information Administration, Form ElA-28. 


\section{Glossary}

Acquisition Costs: Direct costs and indirect costs incurred to acquire legal rights to wasting natural resources. Direct costs include costs incurred to obtain options to lease or purchase mineral rights and costs incurred for the actual leasing (e.g., lease bonuses) or purchasing of the rights. Indirect costs include such costs as: brokers' commissions and expenses; abstract and recording fees; filing and patenting fees; and costs of legal examination of title and documents.

Acreage: An area, measured in acres, that is subject to ownership or control by those holding total or fractional shares of working interests. Acreage is considered developed when development has been completed. (See definition for Working Interest.) A distinction may be made between "gross" acreage and "net" acreage:

- Gross. All acreage covered by any working interest, regardless of the percentage of ownership in the interest.

- Net. Gross acreage adjusted to reflect the percentage of ownership in the working interest in the acreage.

Affiliate: An "affiliate" of, or a person "affiliated" with, a specific person is a person that directly, or indirectly through one or more intermediaries, controls, or is controlled by, or is under common control with, the person specified. The term "affiliate" includes any subsidiary or parent of the person specified.

Amortization: The depreciation, depletion, or charge-off to expense of intangible and tangible assets over a period of time. In the extractive industries, the term is most frequently applied to mean either (1) the periodic charge-off to expense of the costs associated with nonproducing mineral properties incurred prior to the time when they are developed and entered into production or (2) the systematic charge-off to expense of those costs of productive mineral properties (including tangible and intangible costs of prospecting, acquisition, exploration, and development) that had been initially capitalized (or deferred) prior to the time the properties entered into production, and thereafter are charged off as minerals are produced.

Branded Product: A refined petroleum product sold by a refiner with the understanding that the purchaser has the right to resell the product under a trademark, trade name, service mark, or other identifying symbol or names owned by such refiner.

Christmas Tree: The valves and fittings installed at the top of a gas or oil well to control and direct the flow of well fluids.

Coal Gasification: The process of converting coal into gas. The basic process involves crushing coal to a powder, which is then heated in the presence of steam and oxygen to produce a gas. The gas is then refined to reduce sulfur and other impurities. The gas can be used as a fuel or processed further and concentrated into chemical or liquid fuel.

Coal Liquefaction: A chemical process that converts coal into clean-burning liquid hydrocarbons, such as synthetic crude oil and methanol.

Coal Regions: The following regional definitions are used to report domestic coal reserves, production, and other operating statistics.

- Eastern Region. Consists of the Northern Appalachian Coal Basin. The following States comprise the Eastern Region: Alabama, Georgia, Ohio, Maryland, Mississippi, Pennsylvania, Virginia, Tennessee, North Carolina, West Virginia, and Eastern Kentucky.

- Midwest Region. Consists of the Illinois and Michigan Coal Basins. The following States comprise the Midwest Region: Illinois, Indiana, Michigan, and Western Kentucky.

- Western Region. Consists of the Northern Rocky, Scuthern Rocky, Western Interior, and West Coast Coal Basins. The following States comprise the Central Western Region: Alaska, Arizona, Arkansas, California, Colorado, Idaho, Iowa, Kansas, Louisiana, Missouri, Montana, New Mexico, North Dakota, Oklahoma, Oregon, Texas, South Dakota, Utah, Washington, and Wyoming.

Company Automotive (Retail) Outlet: Any retail outlet selling motor fuel under a reporting company brand name. (See definition for Branded Product.) 
- Company Operated. A company retail outlet which is operated by salaried or commission personnel paid by the reporting company.

- Lessee. An independent marketer who leases the station and land and has use of tanks, pumps, signs, etc. A lessee dealer typically has a supply agreement with a refiner or a distributor and purchases products at dealer tank wagon prices. The term "lessee dealer" is limited to those dealers who are supplied directly by a refiner or any affiliate or subsidiary company of a refiner. "Direct supply" includes use of commission agent or common carrier delivery.

- Open. An independent marketer who owns or leases (from a third party who is not a refiner) the station or land of a retail outlet and has use of tanks, pumps, signs, etc. An open dealer typically has a supply agreement with a refiner or a distributor and purchases products at or below dealer tank wagon prices.

Contribution to Net Income: The FRS segment equivalent of net income. However, many consolidated items of revenue and expense are not allocated to the segments, and therefore they are not equivalent in a strict sense. The largest item not allocated to the segments is interest expense since this is regarded as a corporatelevel item for FRS purposes.

Crude Oil: A mixture of hydrocarbons that exists in liquid phase in natural underground reservoirs and remains liquid at atmospheric pressure after passing through surface separating facilities. For FRS reporting, volumes reported as crude include:

- Liquids technically defined as crude oil.

- Small amounts of hydrocarbons that exist in the gaseous phase in natural underground reservoirs but are liquid at atmospheric pressure after being recovered from oil well (casinghead) gas in lease separators and are commingled with the crude stream without being separately measured.

- Small amounts of nonhydrocarbons produced with the oil.

Statistical data pertaining to crude oil production and reserves are reported as liquid equivalents at the surface (excluding base sediment and water) measured in terms of stock tank barrels of 42 U.S. gallons at atmospheric pressure, corrected to 60 degrees Fahrenheit.

Where a State regulatory agency specifies a definition of crude oil which differs from that set forth above for statistical purposes, the State definition should be followed.

DD\&A: Abbreviation for depreciation, depletion and amortization.

Deferred Taxes: Taxes accrued and reflected as an expense in a company's income statement, but not payable to the taxing authority in that time period. These taxes are accrued to compensate for an understatement of income tax expense which would occur if only the tax currently due to the taxing authority were reflected as the total income tax expense.

Depletion: A term for either (1) a periodic assignment to expense of recorded amounts or (2) an allowable income tax deduction that is related to the exhaustion of mineral reserves. Depletion is included as one of the elements of amortization. When used in that manner, depletion refers only to book depletion (see definition for Amortization).

- Book. The portion of the carrying value (other than the portion associated with tangible assets) prorated in each accounting period, for financial reporting purposes, to the extracted portion of an economic interest in a wasting natural resource.

- Tax-cost. A deduction (allowance) under U.S. Federal Income taxation normally calculated under a formula whereby the adjusted basis of the mineral property is multiplied by a fraction, the numerator of which is the number of units of minerals sold during the tax year and the denominator of which is the estimated number of units of unextracted minerals remaining at the end of the tax year plus the number of units of minerals sold during the tax year.

- Tax-percentage (or Statutory). A deduction (allowance) allowed to certain mineral producers under U.S. Federal income taxation calculated on the basis of a specified percentage of gross revenue from the sale of minerals from each mineral property not to exceed the lesser of 50 percent of the taxable income from the property computed without allowance for depletion. (There are also other limits on percentage depletion on oil and gas production.) The taxpayer is entitled to a deduction representing the amount of tax-cost depletion or percentage (statutory) depletion, whichever is higher.

- Excess Statutory Depletion. The excess of estimated statutory depletion allowable as an income tax deduction over the amount of cost depletion otherwise allowable as a tax deduction, determined on a total enterprise basis. 
Depreciation: See definition for Amortization.

Development: The preparation of a specific mineral deposit for commercial production; this preparation includes construction of access to the deposit and of facilities to extract the minerals. The development process is sometimes further distinguished between a preproduction stage and a current stage, with the distinction being made on the basis of whether the development work is performed before or after production from the mineral deposit has commenced on a commercial scale.

Development Costs: Costs incurred to obtain access to proved reserves and to provide facilities for extracting, treating, gathering, and storing the oil and gas.

Drilling: The act of boring a hole (1) to determine whether minerals are present in commercially recoverable quantities and (2) to accomplish production of the minerals (including drilling to injuct fluids).

- Exploratory. Drilling to locate probable mineral deposits or to establish the nature of geological structures; such wells may not be capable of production if minerals are discovered.

- Developmental. Drilling to delineate the boundaries of a known mineral deposit to enhance the productive capacity of the producing mineral property.

- Directional. Drilling that is deliberately made to depart significantly from the vertical.

Drilling and Equipping of Wells: The drilling and equipping of wells through completion of the "christmas tree."

Dry-Hole Charge: The charge-off to expense of a previously capitalized cost upon the conclusion of an unsuccessful drilling effort.

Equity in Earnings of Unconsolidated Affiliates: A company's proportional share (based on ownership) of the net earnings or losses of an unconsolidated affiliate.

Exploration: The identification of areas that may warrant examination and to examine specific areas that are considered to have prospects of containing oil and gas reserves, including drilling exploratory wells and exploratory-type stratigraphic test wells. Exploration costs may be incurred both before acquiring the related property (sometimes referred to in part as prospecting costs) and after acquiring the property.

Exploration Costs: Costs, including depreciation and applicable operating costs, of support equipment and facilities and other costs directly identifiable with exploration activities, such as:

- Costs of topographical, geological, and geophysical studies, rights of access to properties to conduct those studies, and salaries and other expenses of geologists, geophysical crews, and others conducting those studies. Collectively, these costs are sometimes referred to as geological and geophysical or "G\&G" costs.

- Costs of carrying and retaining undeveloped properties, such as delay rentals, ad valorem taxes on the properties, legal costs for title defense, and the maintenance of land and lease records.

- Dry hole contributions and bottom hole contributions. Costs of drilling and equipping exploratory wells.

- Costs of drilling exploratory-type stratigraphic test wells.

Extraordinary Item: Income and expense items associated with events and transactions that possess a high degree of abnormality and are of a type that would not reasonably be expected to recur in the foreseeable future.

Field: An area consisting of a single reservoir or multiple reservoirs all grouped on or related to the same individual geological structural feature and/or stratigraphic condition. There may be two or more reservoirs in a field which are separated vertically by intervening impervious strata, or laterally by local geologic barriers, or by both.

Footage Drilled: Total footage for wells in various categories, as reported for any specified period, includes (1) the deepest total depth (length of well bores) of all wells drilled from the surface, (2) the total of all bypassed footage drilled in connection with reported wells, and (3) all new footage drilled for directional "sidetrack" wells. Footage reported for directional "sidetrack" wells does not include footage in the common bore which is reported as footage for the original well. In the case of old wells drilled deeper, the reported footage is that which was drilled below the total depth of the old well.

- Deepest Total Depth. The deepest total depth of a given well is the distance from a surface reference point (usually the Kelly bushing) to the point of deepest penetration measured along the well bore. If a well is drilled from a platform or barge over water, the depth of the water is included in the total length of the well bore. 
- Sidetrack Drilling. This is a remedial operation that results in the creation of a new section of well bore for the purpose of (1) detouring around junk, (2) redrilling lost hole, or (3) straightening key seats and crooked holes. Directional "sidetrack" wells do not include footage in the common bore which is reported as footage for the original well.

Foreign Access: Refers to proved reserves of crude (including lease condensate) and natural gas liquids applicable to long-term supply agreements with foreign governments or authorities in which the company acts as producer.

Foreign Operations: These are operations that are located outside the United States. Determination of whether an enterprise's mobile assets, such as offshore drilling rigs or ocean-going vessels, constitute foreign operations should depend on whether such assets are normally identified with operations located outside the United States.

Foreign operations are segregated into the following areas for FRS reporting purposes:

- OECD Europe. Includes Austria, Belgium, Denmark, Finland, France, the Federal Republic of Germany, Greece, Iceland, Ireland, Italy, Luxembourg, the Netherlands, Norway, Portugal, Spain, Sweden, Switzerland, Turkey, and the United Kingdom.

- Middle East. Includes Saudi Arabia, the United Arab Emirates, Iraq, Iran, Kuwait, the Iraq-Saudi Arabia Neutral Zone, Qatar, Dubai, Bahrain, Oman, Yemen, Syria, Jordan, and Israel.

- Canada.

- Africa (the African continent).

- Other Eastern Hemisphere. Areas eastward of the Greenwich prime meridian to 180 degrees longitude and not included in other specified domestic or foreign classifications.

- Other Western Hemisphere. Areas westward of the Greenwich prime meridian to 180 degrees longitude not included in other domestic or foreign classifications.

Funds From Operations: Calculated by adding noncash charges back to net income or contribution to net income. Deferred taxes and depreciation, depletion, and amortization (DD\&A) are the largest noncash charges.

Funds, Total Sources of: The total source of funds including net income plus noncash charges such as
DD\&A and deferred taxes, issuances of stocks and bonds, and proceeds from the sale or property, plant, and equipment. The concept is similar to cash flow generated, but does not attempt to account for changes in working capital items. Thus, for example, an inventory buildup or drawdown would not be accounted for under the "funds" concept since both cash and inventory are items of working capital.

Geological and Geophysical (G\&G) Costs: Costs incurred in making geological and geophysical studies, including, but not limited to, costs incurred for salaries, equipment, obtaining rights of access, and supplies for scouts, geologists, and geophysical crews.

Hydrocarbon: An organic chemical compound of hydrogen and carbon in either the gaseous, liquid, or solid phase. The molecular structure of hydrocarbon compounds varies from the simplest (e.g., methane, a constituent of natural gas) to the very heavy and very complex.

Improved Recovery: The operation whereby crude oil or natural gas is recovered using any method other than those that rely primarily on the use of natural reservoir pressure, gas lift or the use of a pump.

Intangible Drilling and Development Costs (IDC): Costs incurred in preparing well locations, drilling and deepening wells, and preparing wells for initial production up through the point of installing control valves. None of these functions, because of their nature, have salvage value. Such costs would include labor, transportation, consumable supplies, drilling tool rentals, site clearance, and similar costs.

Investment and Advances to Unconsolidated Affiliates: The balance sheet account representing the cost of investments and advances to unconsolidated affiliates. Generally, affiliates which are less than 50 percent owned by a company may not be consolidated into the company's financial statements.

Lease Bonus: An amount paid by a lessee to a lessor as consideration for granting a lease, usually as a lump sum; this payment is in addition to any rental or royalty payments.

Lease Equipment: All equipment located on the lease except the well and the complete christmas tree installation.

Lifting Costs: The costs associated with the extraction of a mineral reserve from a producing property. (See definition for Production Cost.) 
Mineral: Any of the various naturally occurring substances (such as coal, crude oil, metals, natural gas, salt, sand, stone, sulfur, and water) usually obtained from the earth. The term is used to include all wasting, i.e., nonregenerative, inorganic substances that are extracted from the earth.

Mineral Interests in Properties (hereinafter referred to as Properties): These include fee ownership or a lease, concession, or other contractual interest representing the right to extract minerals subject to such terms as may be imposed by the conveyance of those interests. Properties also include royalty interests, production payments payable in oil or gas, and other nonoperating interests in properties operated by others. Properties include those agreements with foreign governments or authorities under which an enterprise participates in the operation of the related properties or otherwise serves as "producer" of the underlying reserves, but properties do not include other supply agreements or contracts that represent the right to purchase (as opposed to extract) oil and gas. Mineral Lease: An agreement wherein a mineral interest owner (lessor) conveys to another party (lessee) the rights to explore for, develop, and produce specified minerals. The lessee acquires a working interest and the lessor retains a nonoperating interest in the property, referred to as the royalty interest, each in proportions agreed upon.

Mineral Rights: The ownership of the minerals beneath the earth's surface with the right to remove them. Mineral rights may be conveyed separately from surface rights.

Mining: Any activity directed to the extraction of ore and associated rock. Included are open pit work, quarrying, augering, alluvial dredging, and combined operations, including surface and underground operations.

Minority Interest in Income: The proportional share of the minority ownership's interest (less than 50 percent) in the earnings or losses of the consolidated subsidiary.

Subsidiaries are generally fully consolidated when a share of ownership between 51 percent and 100 percent is held by the parent. In consolidation, 100 percent of revenues, expenses, assets, etc. are included in the financial statements even though, for example, the subsidiary is only 80 percent owned by the parent company. In such cases, the consolidated balance sheet must have a caption on the right-hand side titled something like "minority interests in consolidated affiliates," and the income statement must have a similar line to reduce net income to the pro rata $(80$ percent in this example) share of the consolidated subsidiary's net income.

Motor Gasoline: Refers to blended gasoline suitable as fuel for use in spark ignition systems and within American Society for Testing and Materials (ASTM) specifications D 439.

Natural Gas: A mixture of hydrocarbon compounds and small quantities of various nonhydrocarbons existing in the gaseous phase or in solution with crude oil in natural underground reservoirs at reservoir conditions. The principal hydrocarbons usually contained in the mixture are methane, ethane, propane, butanes, and pentanes. Typical nonhydrocarbon bases which may be present in reservoir natural gas are carbon dioxide, helium, hydrogen sulfide, and nitrogen. Under reservoir conditions, natural gas and the liquefiable portions thereof occur either in a single gaseous phase in the reservoir or in solution with crude oil and are not distinguishable at that time as separate substances.

Natural gas, based on the type of occurrence in the reservoir, is classified by two categories, as follows:

- Non-Associated Gas is natural gas that is not in contact with significant quantities of crude oil in the reservoir.

- Associated/Dissolved Gas is the combined volume of natural gas which occurs in crude oil reservoirs either as free gas (associated) or as gas in solution with crude oil (dissolved).

Associated gas is free natural gas, commonly known as gas cap gas, which overlies and is in contact with crude oil in the reservoir. Dissolved gas is natural gas that is in solution with crude oil in the reservoir at reservoir conditions.

Statistical data pertaining to natural gas production and reserves are reported in units of 1,000,000 cubic feet (i.e., MMCF) at 14.73 pounds per square inch absolute and 60 degrees Fahrenheit for FRS purposes.

Natural Gas Liquids (NGL): Natural gas liquids are those portions of reservoir gas which are liquefied at the surface in lease separators, field facilities, or gas processing plants. Natural gas liquids include but are not limited to: ethane, propane, butanes, pentanes, natural gasoline and condensate.

Net Investment in Place: The sum of net property, plant, and equipment (PP\&E) plus investment and advances to unconsolidated affiliates. 
Nonbranded Product: Any refined petroleum product that is not a branded product.

Nuclear Fuel Operations: All nuclear fuel operations, excluding reactor and reactor component manufacturing or containment construction. Includes exploration and development; mining; milling; conversion; enrichment; fabrication; reprocessing; and spent fuel storage.

Offshore: That geographic area that lies seaward of the coastline. In general, the coastline is the line of ordinary low water along with that portion of the coast that is in direct contact with the open sea or the line marking the seaward limit of inland water.

If a State agency uses a different basis for classifying onshore and offshore areas, the State classification should be used. (Cook Inlet in Alaska is classified as offshore.)

Oil Shale: A sedimentary rock containing kerogen, a solid organic material.

Operating Expenses: Segment expenses related both to revenue from sales to unaffiliated customers and revenue from intersegment sales or transfers, excluding loss on disposition of property, plant, and equipment; interest expenses and financial charges; foreign currency translation effects; minority interest; and income taxes.

Operating Income: Operating revenues less operating expenses. Excludes items of other revenue and expense such as equity in earnings of unconsolidated affiliates, dividends, interest income and expense, income taxes, extraordinary items, and cumulative effect of accounting changes.

Operating Revenues: Segment revenues both from sales to unaffiliated customers (i.e., revenue from customers outside the enterprise as reported in the company's consolidated income statement) and from intersegment sales or transfers, if any, of product and services similar to those sold to unaffiliated customers, excluding equity in earnings of unconsolidated affiliates; dividend and interest income; gain on disposition of property, plant, and equipment; and foreign currency translation effects.

Other Energy Operations: Energy operations not included in Petroleum or Coal. Other Energy includes nuclear fuel, oil shale, tar sands, geothermal, and coal liquefaction and gasification.

PP\&E, Additions to: The current year's expenditures on property, plant, and equipment (PP\&E). The amount is predicated upon earh reporting company's accounting practice. That is, accounting practices with regard to capitalization of certain items may differ across companies, and therefore this figure in FRS will be a function of each reporting company's policy.

PP\&E, Net: The original cost of property, plant, and equipment (PP\&E), less accumulated depreciation.

Petroleum: Hydrocarbon mixtures broadly defined to include crude oil, lease condensate, natural gas, products of natural gas processing plants (plant products), refined products, and semifinished products and blending materials.

Pipelines, Rate Regulated: FRS establishes three pipeline segments; crude/liquid (raw materials); natural gas; and refined products. The pipelines included in these segments are all federally or state rate-regulated pipeline operations, which are included in the reporting company's consolidated financial statements. However, at the reporting company's option intrastate pipeline operations may be included in the U.S. Refining/ Marketing Segment if: they would comprise less than 5 percent of U.S. Refining/Marketing Segment net $P P \& E$, revenues and earnings in the aggregate; and if the inclusion of such pipelines in the consolidated financial statements adds less than $\$ 100$ million to the net PP\&E reported for the U.S. Refining/Market Segment.

Primary Recovery: The crude oil or natural gas recovered by any method that may be employed to produce them where the fluid enters the well bore by the action of natural reservoir pressure (energy or gravity).

Primary Transportation: Conveyance of large shipments of petroleum raw materials and refined products usually by pipeline, barge, or ocean-going vessel. All crude oil transportation is primary, including the small amounts moved by truck. All refined product transportation by pipeline, barge, or ocean-going vessel is primary transportation.

Producing Property: A term often used in reference to a property, well, or mine that produces wasting natural resources. The term means a property that produces in paying quantities (that is, one for which proceeds from production exceed operating expenses).

Production, Natural Gas Liquids: Production of natural gas liquids is classified as follows:

- Contract Production. Natural gas liquids accruing to a company because of its ownership of liquids extraction facilities that it uses to extract liquids 
from gas belonging to others, thereby earning a portion of the resultant liquids.

- Leasehold Production. Natural gas liquids produced, extracted, and credited to a company's interest.

- Contract Reserves. Natural gas liquid reserves corresponding to the contract production defined above.

- Leasehold Reserves. Natural gas liquid reserves corresponding to the leasehold production defined above.

Production, Oil and Gas: The lifting of the oil and gas to the surface and gathering, treating, field processing (as in the case of processing gas to extract liquid hydrocarbons), and field storage. The production function shall normally be regarded as terminating at the outlet valve on the lease or field production storage tank; if unusual physical or operational circumstances exist, it may be more appropriate to regard the production function as terminating at the first point at which oil, gas, or gas liquids are delivered to a main pipeline, a common carrier, a refinery, or a marine terminal.

- Gross Company-Operated Production. Total production from all company operated properties including all working and nonworking interests.

- Net Working Interest Production. Total production accruing to the reporting company's working interests less royalty oil and volumes due others.

Production Costs: Costs incurred to operate and maintain wells and related equipment and facilities, including depreciation and applicable operating costs of support equipment and facilities and other costs of operating and maintaining those wells and related equipment and facilities. They become part of the cost of oil and gas produced. The following are examples of production costs (sometimes called lifting costs):

- Costs of labor to operate the wells and related equipment and facilities.

- Repair and maintenance costs.

- The costs of materials, supplies and fuel consumed and services utilized in operating the wells and related equipment and facilities.

- The costs of property taxes and insurance applicable to proved properties and wells and related equipment and facilities.

- The costs of severance taxes.

Depreciation, depletion, and amortization (DD\&A) of capitalized acquisition, exploration, and development costs are not production costs but also become part of the cost of oil and gas produced along with production (lifting) costs identified above.

Production costs include the following subcategories of costs:

- Well operations and maintenance

- Well workovers

- Operating fluid injection and improved recovery programs

- Operating gas processing plants

- Ad valorem taxes

- Production or severance taxes

- Other, including overhead

Research and Development: Basic and applied research in the sciences and engineering and the design and development of prototypes and processes, excluding quality control, routine product testing, market research, sales promotion, sales service, research in the social sciences or psychology, and other non-technological activities or technical services.

Reserves, Change in: For FRS reporting, the following definitions should be used for changes in reserves.

- Revisions of Previous Estimates. Changes in previous estimates of proved reserves, either upward or downward, resulting from new information normally obtained from development drilling and production history or resulting from a change in economic factors. Revisions do not include changes in reserve estimates resulting from increases in proved acreage or from improved recovery techniques.

- Improved Recovery. Changes in reserve estimates resulting from application of improved recovery techniques shall be separately shown, if significant. If not significant, such changes shall be included in revisions of previous estimates.

- Purchases or Sales of Minerals-in-Place. Increase or decrease in the estimated quantity of reserves resulting from the purchase or sale of mineral rights in land with known proved reserves.

- Extensions, Discoveries, and Other Additions. Additions to an enterprise's proved reserves that result from (1) extension of the proved acreage of previously discovered (old) reservoirs through additional drilling in periods subsequent to discovery and (2) discovery of new fields with proved reserves or of new reservoirs of proved reserves in old fields. 
Reserves (Coal): Coal reserve estimates comprising the demonstrated coal reserve base include only proved (measured) and probable (indicated).

- Proved (Measured) Reserves. Reserves cr resources for which tonnage is computed from dimensions revealed in outcrops, trenches, wrorkings, and drill holes and for which the grade ir computed from the results of detailed sampling. The sites for inspection, sampling, and measu. ament are spaced so closely and the geologic character is so well defined that size, shape, and mine al content are well established. The computed to unage and grade are judged to be accurate within limits which are stated, and no such limit is judged $t \mathrm{~s}$ be different from the computed tonnage or grade by more than 20 percent.

- Probable (Indicated) Reserves. Reserves or resources for which tonnage and grade are computed partly from specific measurements, samples, or production data and partly from projection for a reasonable distance on geologi : evidence. The sites available are too widely or otherwise inappropriately spaced to permit the mineral bodies to be outlined completely or the grade established throughout.

Reserves, Net: Includes all proved reserves associated with the company's net working interests. (See definition for Working Interest.)

Reserves, Proved (Oil and Gas): The estimated quantities of crude oil, natural gas, and natural gas liquids which geological and engineering data demonstrate with reasonable certainty to be recoverable in future years from known reservoirs under existing economic and operating conditions.

Reserves that can be produced economically through application of improved recovery techniques (such as fluid injection) are included in the "proved" classification when successful testing by a pilot project, or the operation of an installed program in the reservoir, provides support for the engineering analysis on which the project or program was based.

Estimates of proved reserves do not include the following: (1) oil that may become available from known reservoirs but is classified separately as "indicated additional reserves;" (2) crude oil, natural gas, and natural gas liquids, the recovery of which is subject to reasonable doubt because of uncertainty as to geology, reservoir characteristics, or economic factors; (3) crude oil, natural gas, and natural gas liquids that may occur in undrilled prospects; and (4) crude oil, natural gas, and natural gas liquids, that may be recovered from oil shales, coal, gilsonite and other such sources.

It is not necessary that production, gathering, or transportation facilities be installed or operative for a reservoir to be considered proved.

For natural gas an appropriate reduction in the reservoir gas volume is made to cover the removal of the liquefiable portions of the gas and the exclusion of nonhydrocarbon gases where they occur in sufficient quantity to render the gas unmarketable. If the liquefiable portions of the gas are not separately estimated, they need not be separately stated for FRS reporting purposes.

Reservoir: $A$ porous and permeable underground formation containing an individual and separate accumulation of producible hydrocarbons (oil and/or gas) that is confined by impermeable rock or water barriers and is characterized by a single natural pressure system.

Residual Fuel: Topped crude obtained by refinery operations including light and heavy grades 5 and 6 , heavy diesel fuel, type S-M diesel fuel, navy grade, navy special, bunker $C$, and acid sludge.

Royalty: A contractual arrangement providing a mineral interest that gives the owner a right to a fractional share of production or proceeds therefrom, that does not contain rights and obligations of operating a mineral property, and that is normally free and clear of exploration, developmental, and operating costs, except production taxes.

Short Ton: A unit of weight that equals 2,000 pounds.

Support Equipment and Facilities: These include, but are not limited to, seismic equipment, drilling equipment, construction and grading equipment, vehicles, repair shops, warehouses, supply points, camps, and division, district, or field offices.

Tangible Development Costs: Cost incurred during the development stage for access, mineral-handling, and support facilities having a physical nature. In mining, such costs would include tracks, lighting equipment, ventilation equipment, other equipment installed in the mine to facilitate the extraction of minerals, and supporting facilities for housing and care of work forces. In the oil and gas industry, tangible development costs would include well equipment (such as casing, tubing, pumping equipment, and well heads), as well as field storage tanks and gathering systems. 
Tar Sands: Naturally occurring bitumen-impregnated sands that yield mixtures of liquid hydrocarbon and that require further processing other than mechanical blending before becoming finished petroleum products.

Timing Differences: Differences between the periods in which transactions affect taxable income and the periods in which they enter into the determination of pretax accounting income. Timing differences originate in one period and reverse or "turn around" in one or more subsequent periods. Some timing differences reduce income taxes that would otherwise be payable currently; others increase income taxes that would otherwise be payable currently.

Transfer Price: The monetary value assigned to products, services, or rights conveyed or exchanged between related parties, including those occurring between units of a consolidated entity.

Uncompleted Wells, Equipment, and Facilities Costs: The costs incurred to (1) drill and equip wells that are not yet completed, and (2) acquire or construct equipment and facilities that are not yet completed and installed.

Undeveloped Property: Refers to a mineral property on which development wells or mines have not been drilled or completed to a point that would permit the production of commercial quantities of mineral reserves.

Uranium Oxide: The final precipitate formed in the uranium milling process. $\mathrm{U}_{3} \mathrm{O}_{8}$, a common form of triuranium oxide, is the powder obtained by evaporating an ammonial solution of the oxide.

Well: A hole drilled in the earth for the purpose of (1) finding or producing crude oil or natural gas; or (2) providing services related to the production of crude oil or natural gas.

Wells are classified as (1) oil wells; (2) gas wells; (3) dry holes; (4) stratigraphic test wells; or (5) service wells. The latter two types of wells are not counted for FRS reporting.

Oil wells, gas wells, and dry holes are classified as exploratory wells or development wells. Exploratory wells are subclassified as (1) new-pool wildcats; (2) deeper-pool tests; (3) shallow-pool test; and (4) outpost (extension) tests. Well classifications reflect the status of wells after drilling has been completed.

- Completion. The term refers to the installation of permanent equipment for the production of oil or gas.

- Development Well. A well drilled within the proved area of an oil or gas reservoir to the depth of a stratigraphic horizon known to be productive.

- Dry Hole. An exploratory or development well found to be incapable of producing either oil or gas in sufficient quantities to justify completion as an oil or gas well.

- Exploratory Well. A well that is not a development well, a service well, nor a stratigraphic test as those items are defined elsewhere.

- Oil Well. A well completed for the production of crude oil from at least one oil zone or reservoir.

Wellhead Price: The value at the mouth of the well. In general, the wellhead price is considered to be the sales price obtainable from a third party in an arm's length transaction. Posted prices, requested prices, or prices as defined by lease agreements, contracts or tax regulations should be used where applicable.

Working Interest: An interest in a mineral property that entitles the owner of that interest to all of a share of mineral production from the property, usually subject to a royalty.

A working interest permits the owner to explore, develop and operate the property. The working interest owner bears the costs of exploration, development, and operation of the property, and in return is entitled to a share of the mineral production from the property, or to a share of the proceeds therefrom. It may be assigned to another party in whole or in part, or it may be divided into other special property interests.

- Gross Working Interest. The reporting company's working interest plus the proportionate share of any basic royalty interest or overriding royalty interest related to the working interest.

- Net Working Interest. The reporting company's working interest not including any basic royalty or overriding royalty interests. 

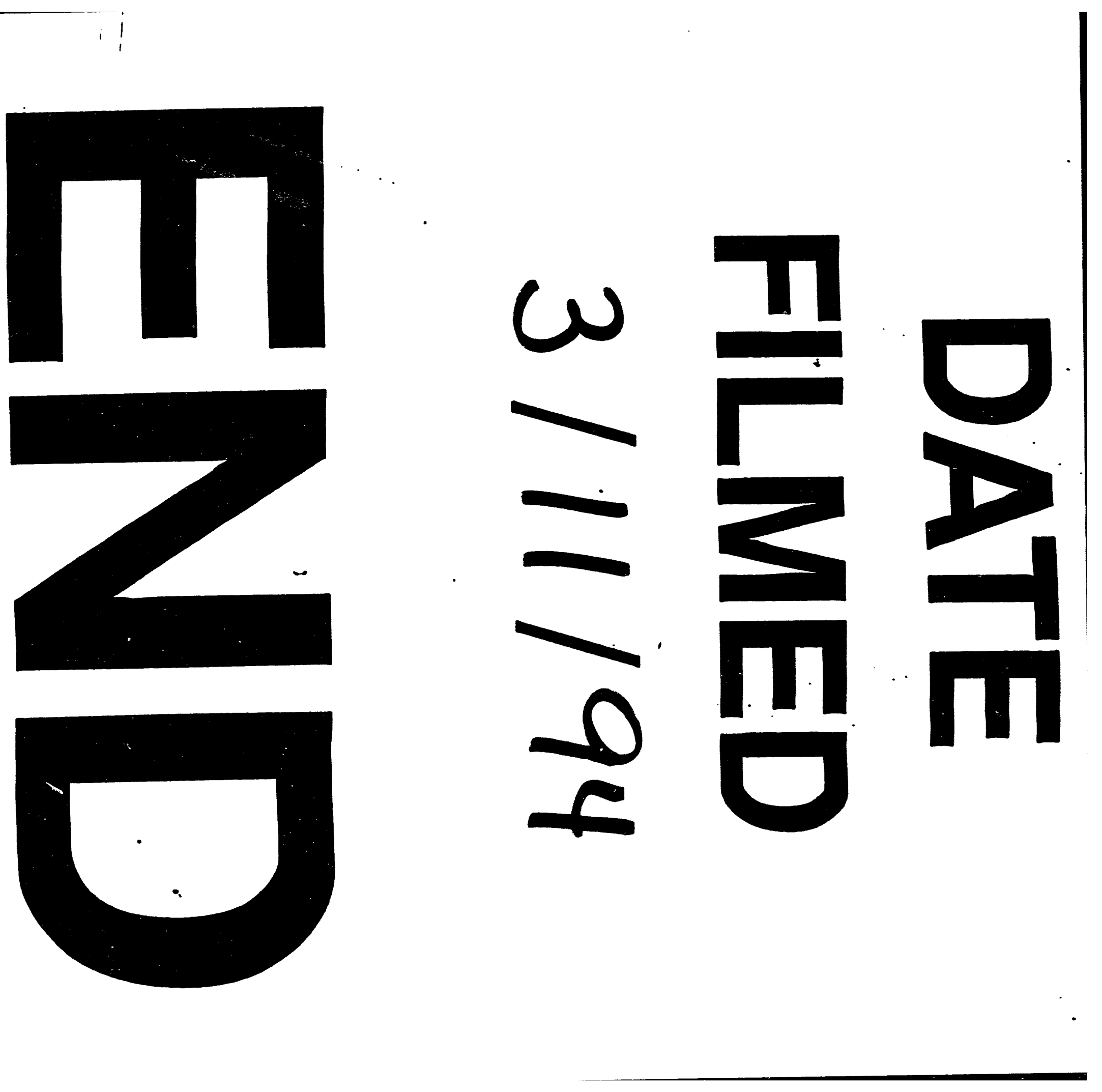


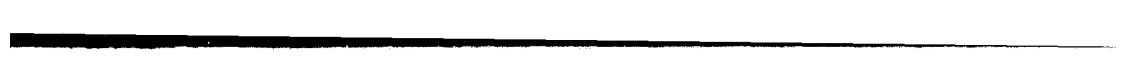

